Prepared in cooperation with the

Massachusetts Department of Conservation and Recreation, and the U.S. Environmental Protection Agency

Effects of Selected Low-Impact-Development (LID) Techniques on Water Quality and Quantity in the Ipswich River Basin, Massachusetts: Field and Modeling Studies
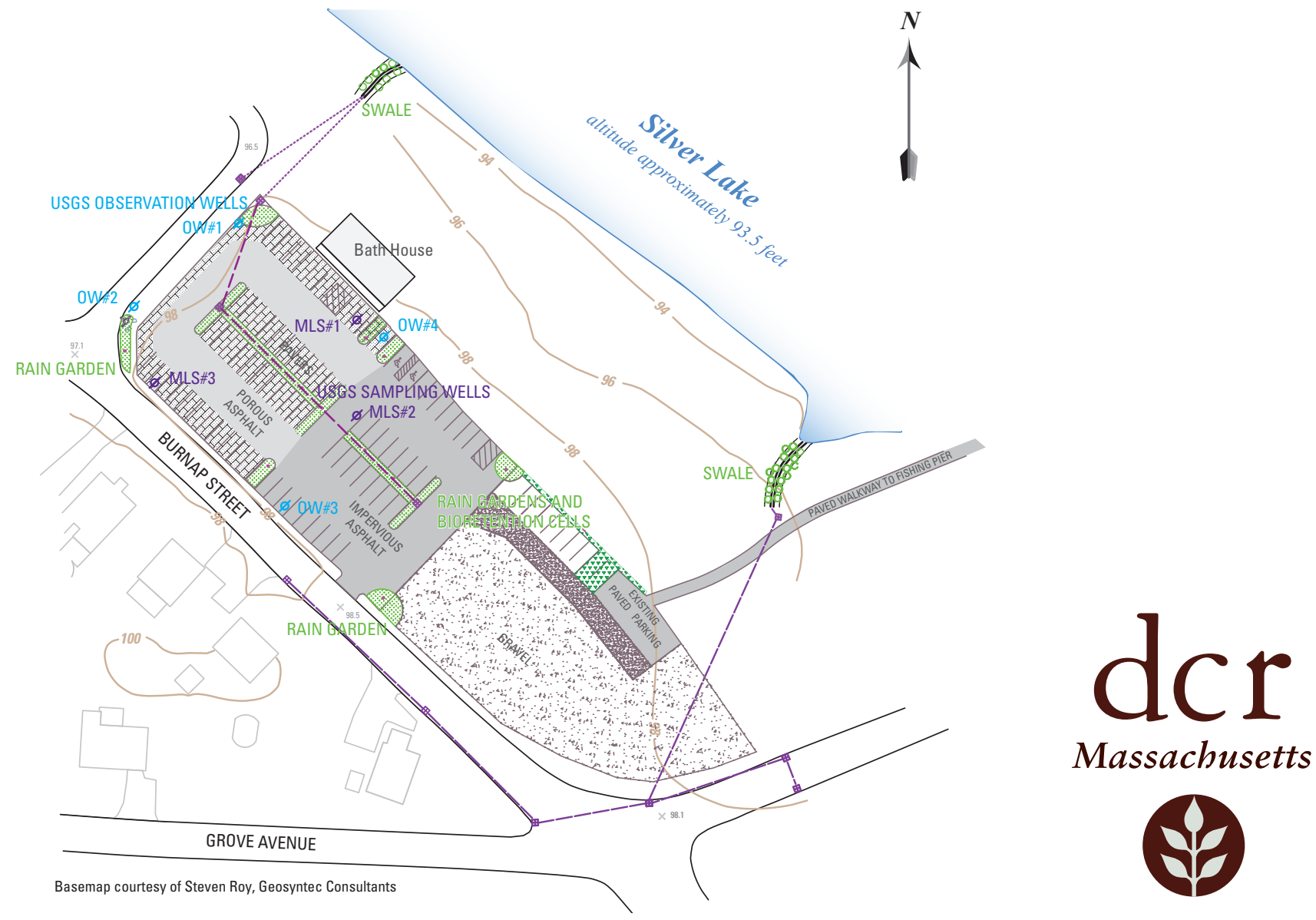

Scientific Investigations Report 2010-5007 
Cover Graphics: Map modifed from Geosyntec Consultants. DCR logo from Massachusetts Department of Recreation. Banner photo, Ipswich River from Green Street Bridge, Ipswich, MA. Whipple Annex photo showing green roof, Ipswich, MA. Parking lot photo showing porous pavers and asphalt, and bioretention cells at Silver Lake parking lot, Wilmington, MA. 


\section{Effects of Selected Low-Impact- Development (LID) Techniques on Water Quality and Quantity in the Ipswich River Basin, Massachusetts: Field and Modeling Studies}

By Marc J. Zimmerman, Jeffrey R. Barbaro, Jason R. Sorenson, and Marcus C. Waldron

Prepared in cooperation with the

Massachusetts Department of Conservation and Recreation and the U.S. Environmental Protection Agency

Scientific Investigations Report 2010-5007 


\section{U.S. Department of the Interior \\ KEN SALAZAR, Secretary \\ U.S. Geological Survey \\ Marcia K. McNutt, Director}

U.S. Geological Survey, Reston, Virginia: 2010

For more information on the USGS - the Federal source for science about the Earth, its natural and living resources, natural hazards, and the environment, visit http://www.usgs.gov or call 1-888-ASK-USGS

For an overview of USGS information products, including maps, imagery, and publications, visit http://www.usgs.gov/pubprod

To order this and other USGS information products, visit http://store.usgs.gov

Any use of trade, product, or firm names is for descriptive purposes only and does not imply endorsement by the U.S. Government.

Although this report is in the public domain, permission must be secured from the individual copyright owners to reproduce any copyrighted materials contained within this report.

Suggested citation:

Zimmerman, M.J., Barbaro, J.R., Sorenson, J.R., and Waldron, M.C., 2010, Effects of selected low-impact-development (LID) techniques on water quality and quantity in the Ipswich River Basin, Massachusetts—Field and modeling studies: U.S. Geological Survey Scientific Investigations Report 2010-5007, 113 p. 


\section{Acknowledgments}

The authors thank Sara Cohen (Massachusetts Department of Conservation and Recreation) and Ralph Abele and Sandra Fancieullo (U.S. Environmental Protection Agency) who provided valuable comments and suggestions throughout the study. Steven Roy, Marcus Quigley, and Andrea Braga (Geosyntec Consultants) freely provided their own insights as well as detailed information about the design of the LID enhancements in Wilmington, MA. Members of the Technical Advisory Committees, Gregory Krom (Topsfield Water Department), Michael O'Halloran (Reading Water Department), Kerry Mackin and Jessica Darling (Ipswich River Watershed Association), Kari Winfield, George Zoto, and Thomas Lamont (Massachusetts Department of Environmental Protection), Marilyn McCrory and Anne Carroll (Massachusetts Department of Conservation and Recreation), Joanne Bissetta (Concord Water Department), Paul Lauenstein (Neponset River Watershed Association), James Rolfe (AquaSave), and Yushiou Tsai (Tufts University), formed for this project assisted with the development of the modeling scenarios, provided updated water-withdrawal and water-conservation information used in the simulations, and conducted technical reviews. Jamie Magaldi (Wilmington Department of Public Works) simplified the logistics of our fieldwork. David Pancoast (Ipswich Conservation Commission) provided specific advice on the siting of our equipment. Rick Doerr (Town of Ipswich) provided support with all aspects of our work at the roof-runoff sites.

USGS colleagues Phillip Zarriello, Leslie DeSimone, Roy Socolow, Andrew Massey, Kimberly Campo, Linda Comeau, Timothy McCobb, John Masterson, Kirk Smith, David Lorenz, and Joyce Williamson provided invaluable technical assistance at various stages of this project. USGS colleagues Leslie DeSimone, Chad Ostheimer, Peter Hughes, and Marie Peppler, and Michael Dietz (Utah State University) served as colleague reviewers, and their thoughtful comments and suggestions substantially improved the clarity and technical accuracy of the report. 
THIS PAGE INTENTIONALLY LEFT BLANK 


\section{Contents}

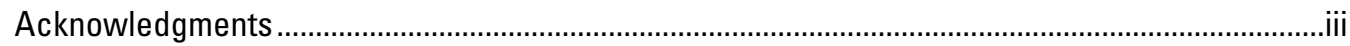

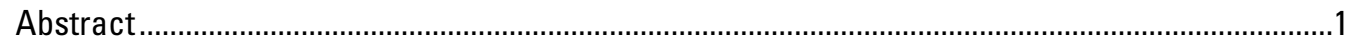

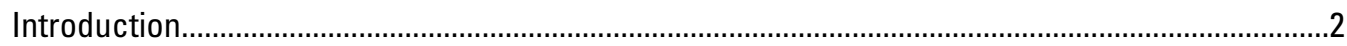

Applications of Low-Impact-Development (LID) Principles and Techniques............................4

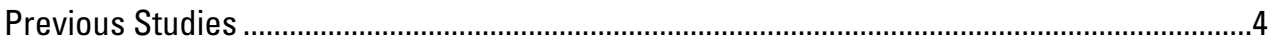

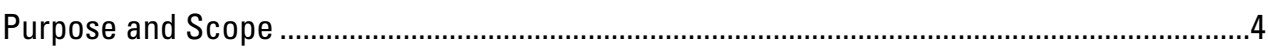

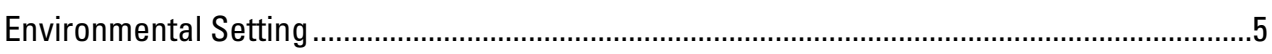

Field Studies of Low-Impact-Development Techniques...............................................................5

Porous Parking Lot Enhancements at

Silver Lake Beach ........................................................................................................5

Design of Low-Impact-Development Enhancements to Increase Infiltration ...................7

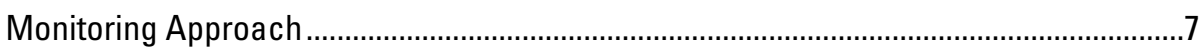

Regional and Local Groundwater Flow .....................................................................

Water-Table Altitude and Water Quality .................................................................. 10

Changes in Groundwater Quality Following the Installation of Low-Impact-

Development Enhancements .............................................................................. 10

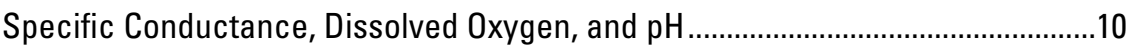

Nutrients, Dissolved Metals, and Total Petroleum Hydrocarbons ..........................23

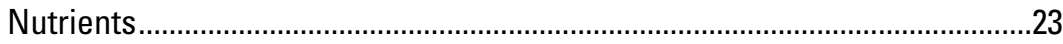

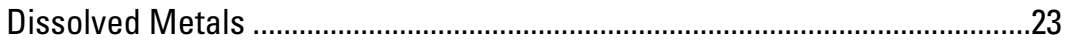

Total Petroleum Hydrocarbons ...............................................................................30

Low-Impact-Development Enhancements at the Silver Lake Avenue/Dexter Street

Neighborhood and Water Quantity and Quality of Stormwater Runoff.........................30

Design of Low-Impact-Development Enhancements to Increase Infiltration.................32

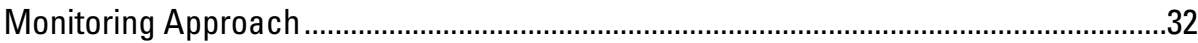

Changes in Runoff Quantity and Quality Following Installation of Low-Impact-

Development Enhancements ..............................................................................37

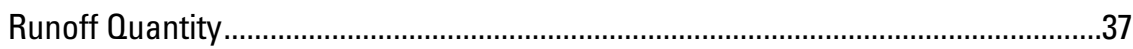

Runoff Quality ................................................................................................................41

Green and Conventional Roofs and the Quantity and Quality of Stormwater Runoff..............47

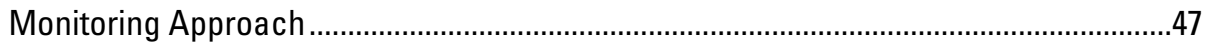

Comparison of Conventional and Green Roof Runoff Quantity and Quality.....................51

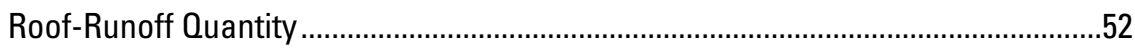

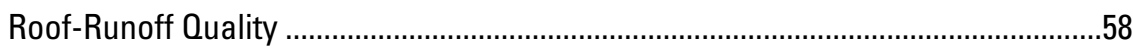

Simulation of the Effects of Land-Use Change and Low-Impact Development on Streamflow at

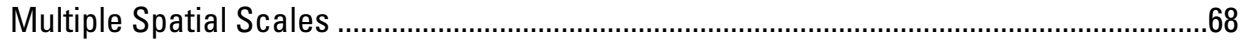

Description of Original Baseline Model ..................................................................................68

Modifications to the Original Baseline Model ...............................................................

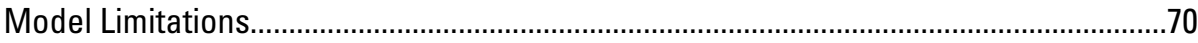

Description of Basin-Scale and Local-Scale Simulations ......................................................71

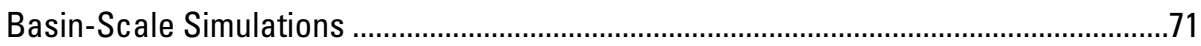

Original Baseline Simulation.......................................................................................... 71

Updated Baseline Simulation ...................................................................................... 71 
Buildout Simulation ................................................................................................

Simulation of Low-Impact-Development Retrofits Upstream from the South Middleton Streamgage ..............................................................................77

Water Conservation Simulation.............................................................................

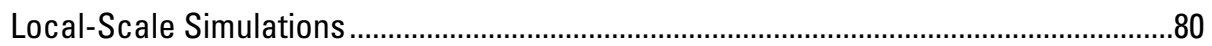

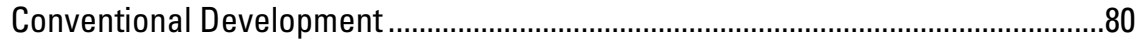

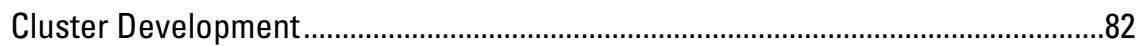

Clustering Practices for High-Density Residential Development....................82

Clustering Practices for Low-Density Residential Development.....................84

Effects of Water-Withdrawal Changes and Low-Impact-Development Practices on

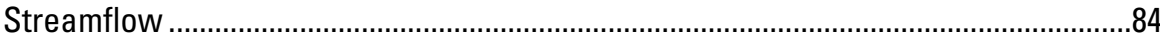

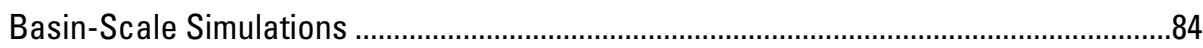

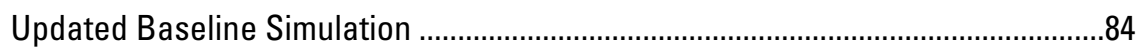

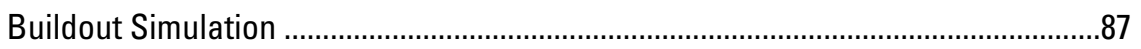

Simulation of Low-Impact-Development Retrofits Upstream from the South Middleton Streamgage.....................................................................90

Water Conservation Simulation............................................................................93

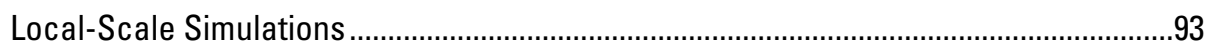

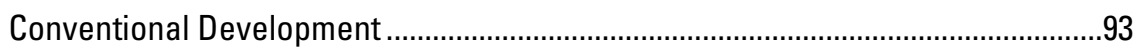

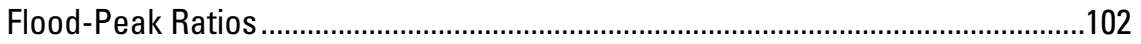

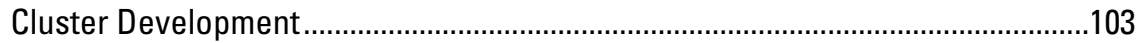

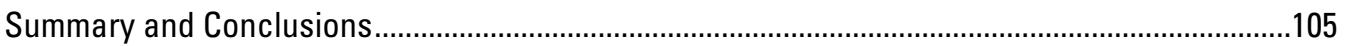

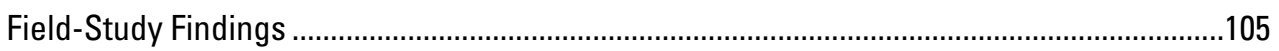

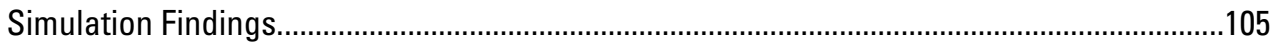

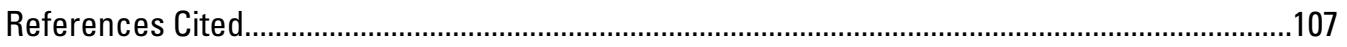

Appendix 1. Data, calculations, and assumptions used to scale up data to the town level from the water-conservation pilot study conducted in the Ipswich

River Basin, MA. 


\section{Figures}

1. Map showing location of streamgages, wells, and weather station in the Ipswich River Basin, MA .

2. Photographs showing views of Silver Lake Beach parking lot in Wilmington, MA, prior to renovation, $(A)$ looking west and $(B)$ looking north.

3. Photograph showing water fowl feeding on Silver Lake Beach in Wilmington, MA, prior to installation of low-impact-development features.

4. Photographs showing views of $(A)$ partially completed porous parking lot at Silver Lake Beach, Wilmington, MA, showing bioretention cells, porous pavers, and gravel bed for porous asphalt and $(B)$ completely renovated parking lot.

5. Map showing generalized groundwater-flow direction in the vicinity of Silver Lake, Wilmington, MA

6. Photographs showing $(A)$ U.S. Geological Survey well drillers installing multilevel samplers. Markings on the white PVC pipe are locations of the sampling ports and $(B)$ color-coded sampling tubes that lead to intake ports in multilevel samplers ...........11

7. Map showing features of Silver Lake Beach parking lot, Wilmington, MA, and generalized groundwater-flow direction

8. Graph showing altitudes of water table determined in multilevel samplers and of Silver Lake, Wilmington, MA, July 2005 to June 2007

9. Graph showing minimum, median, and maximum specific conductance values in groundwater samples collected at multilevel-sampler well number 1 (MLS\#1) before (pre-low-impact development) and after (post-low-impact-development) installation of a porous parking lot at Silver Lake Beach, Wilmington, MA

10. Graph showing minimum, median, and maximum dissolved oxygen concentrations in groundwater samples collected at multilevel-sampler well number 1 (MLS\#1) before (pre-low-impact development) and after (post-low-impact-development) installation of a porous parking lot at Silver Lake Beach, Wilmington, MA

11. Graph showing total ammonia plus organic nitrogen concentrations and water-table altitudes in multilevel-sampler well number 1 (MLS\#1) before and after installation of a porous parking lot at Silver Lake Beach, Wilmington, MA

12. Graph showing dissolved nitrate plus nitrite nitrogen concentrations and water-table altitudes in multilevel-sampler well number 1 (MLS\#1) before and after installation of a porous parking lot at Silver Lake Beach, Wilmington, MA

13. Graph showing dissolved orthophosphorus concentrations and water-table altitudes in multilevel-sampler well number 1 (MLS\#1) before and after installation of a porous parking lot at Silver Lake Beach, Wilmington, MA

14. Graph showing total phosphorus concentrations and water-table altitudes in multilevel-sampler well number 1 (MLS\#1) before and after installation of a porous parking lot at Silver Lake Beach, Wilmington, MA

15. Graph showing dissolved copper concentrations and water-table altitudes in multilevel-sampler well number 1 (MLS\#1) before and after installation of a porous parking lot at Silver Lake Beach, Wilmington, MA

16. Graph showing dissolved lead concentrations and water-table altitudes in altitudes sampler well number 1 (MLS\#1) before and after installation of a porous parking lot at Silver Lake Beach, Wilmington, MA

17. Graph showing dissolved nickel concentrations and water-table altitudes in multilevel-sampler well number 1 (MLS\#1) before and after installation of a porous parking lot at Silver Lake Beach, Wilmington, MA 
18. Graph showing dissolved zinc concentrations and water-table altitudes in multilevel-sampler well number 1 (MLS\#1) before and after installation of a porous parking lot at Silver Lake Beach, Wilmington, MA ....

19. Graph showing total petroleum hydrocarbon concentration and water-table altitudes in multilevel-sampler well number 1 (MLS\#1) before and after installation of a porous parking lot at Silver Lake Beach, Wilmington, MA.

20. Map showing Silver Lake Avenue/Dexter Street neighborhood in Wilmington, $M A$, with drainage features and low-impact-development enhancements. 31

21. Photographs showing rain gardens along Dexter Street, Wilmington, MA. Cutouts in curbs to direct runoff from road into rain garden .........................................................3

22. Photograph showing rain garden along Dexter Street, Wilmington, MA ........................34

23. Photograph showing storm drain at Silver Lake Avenue, Wilmington, MA.....................35

24. Photograph showing runoff-monitoring equipment in a catch basin at Silver Lake Avenue, Wilmington, MA.

25. Photograph showing water draining into a storm-drain grate on Silver Lake Avenue, Wilmington, MA.

26. Boxplots showing rainfall-runoff coefficients determined before (Pre-LID, Aug. 2005-Feb. 2006) and after (Post-LID, Aug. 2006-Nov. 2007) installation of low-impact-development features along Silver Lake Avenue, Wilmington, MA, for $(A)$ all storms monitored during the study period and $(B)$ monitored storms preceded by 100 hours or more of dry conditions.

27. Boxplots showing rainfall-runoff coefficients determined before (Pre-LID, Aug. 2005-Feb. 2006) and after (Post-LID, Aug. 2006-Nov. 2007) installation of low-impact-development features along Silver Lake Avenue, Wilmington, MA, for groups of storms with different amounts of precipitation

28. Graph showing median rainfall-runoff coefficients determined before (Pre-LID, Aug. 2005-Feb. 2006) and after (Post-LID, Aug. 2006-Nov. 2007) installation of low-impact-development features along Silver Lake Avenue, Wilmington, MA, for storms with greater than and less than or equal to 0.25 inch of precipitation.

29. Graph showing relations between total runoff and total precipitation for storms with total precipitation less than 0.26 inch that occurred before (Pre-LID, Aug. 2005-Feb. 2006) and after (Post-LID, Aug. 2006-Nov. 2007) installation of low-impact-development features along Silver Lake Avenue, Wilmington, MA

30. Boxplot showing nitrogen analyte loads in runoff from storms that occurred before (Pre-LID, Aug. 2005-Feb. 2006) and after (Post-LID, Aug. 2006-Nov. 2007) installation of low-impact-development features along Silver Lake Avenue, Wilmington, MA ........44

31. Boxplot showing phosphorus analyte loads in runoff from storms that occurred before (Pre-LID, Aug. 2005-Feb. 2006) and after (Post-LID, Aug. 2006-Nov. 2007) installation of low-impact-development features along Silver Lake Avenue, Wilmington, MA .....

32. Boxplot showing cadmium, chromium, copper, lead, nickel, and zinc loads in runoff from storms that occurred before (Pre-LID, Aug. 2005-Feb. 2006) and after (Post-LID, Aug. 2006-Nov. 2007) installation of low-impact-development features along Silver Lake Avenue, Wilmington, MA

33. Photograph showing structural features of a typical green roof

34. Photograph showing $(A)$ partially developed vegetation in summer 2007 and $(B)$ well-developed vegetation in autumn 2008 on the Whipple Annex green roof, Ipswich, MA.

35. Photograph showing rubber-membrane roof on the Ipswich, MA, Town Hall with drains leading into the building and to the runoff-monitoring and sampling system......49 
36. Photograph showing roof-runoff flow-monitoring and sampling system in the Ipswich Town Hall, Ipswich, MA....

37. Photograph showing roof-runoff flow-monitoring and sampling system during assembly at the Whipple Annex, Ipswich, MA.

38. Graphs showing $(A)$ precipitation on and runoff from conventional rubber and green roofs in Ipswich, MA, for the storm of September 27, 2007, and $(B)$ cumulative percentages of total precipitation and total runoff from the roofs for the same storm.

39. Graphs showing $(A)$ precipitation on and runoff from conventional rubber and green roofs in Ipswich, MA, for the storm of September 9, 2007, and $(B)$ cumulative percentages of total precipitation and total runoff from the roofs for the same storm

40. Graphs showing $(A)$ precipitation on and runoff from conventional rubber and green roofs in Ipswich, MA, for the storm of 0 ctober 26, 2008, and $(B)$ cumulative percentages of total precipitation and total runoff from the roofs for the same storm

41. Graphs showing $(A)$ precipitation on and runoff from conventional rubber and green roofs in Ipswich, MA, for the storm of September 11, 2007, and $(B)$ cumulative percentages of total precipitation and total runoff from the roofs for the same storm

42. Graphs showing $(A)$ precipitation on and runoff from conventional rubber and green roofs in Ipswich, MA, for the storm of September 26, 2008, and $(B)$ cumulative percentages of total precipitation and total runoff from the roofs for the same storm

43. Graph showing percentage of precipitation retained by the Whipple Annex green roof in Ipswich, MA, in relation to total precipitation depth for storms that were monitored from June 2007 through November 2008

44. Graph showing percentage of precipitation retained by the Whipple Annex green roof in Ipswich, MA, in relation to the length of the antecedent dry period and the total amount of precipitation for storms that were monitored from June 2007 through November 2008

45. Boxplots showing concentrations of $(A)$ total nitrogen, $(B)$ total phosphorus, $(C)$ dissolved ammonia nitrogen, $(D)$ dissolved phosphorus, and $(E)$ nitrate plus nitrite nitrogen in bulk precipitation and in runoff from the town hall rubber roof and the Whipple Annex green roof, Ipswich, MA, June 2007 through November 2008

46. Boxplots showing concentrations of $(A)$ total cadmium, $(B)$ total copper, $(C)$ total nickel, $(D)$ total lead, and $(E)$ total zinc in bulk precipitation and in runoff from the town hall rubber roof and the Whipple Annex green roof, Ipswich, MA, June 2007 through November 2008

47. Boxplots showing loads of $(A)$ total nitrogen, $(B)$ total phosphorus, $(C)$ dissolved ammonia nitrogen, $(D)$ dissolved phosphorus, and $(E)$ nitrate plus nitrite nitrogen in bulk precipitation and in runoff from the town hall rubber roof and the Whipple Annex green roof, Ipswich, MA, June 2007 through November 2008.

48. Boxplots showing loads of $(A)$ total cadmium, $(B)$ total copper, $(C)$ total nickel, $(D)$ total lead, and $(E)$ total zinc in bulk precipitation and in runoff from the town hall rubber roof and the Whipple Annex green roof, Ipswich, MA, June 2007 through November 2008.

49. Map showing model reaches and subbasin boundaries in the Ipswich River Basin, MA.

50. Map showing changes in groundwater withdrawals for Reading and Wilmington, $\mathrm{MA}$, for the updated baseline simulation relative to the original baseline simulation....72 
51. Map showing land potentially available for development in the Ipswich River Basin, MA, based on 1991 land use....

52. Map showing generalized land use in the Ipswich River Basin, MA, $(A)$ in 1991 and $(B)$ at buildout

53. Map showing commercial, high-density residential, and low-density residential land use in 1991 for the drainage area to the South Middleton streamgage, Ipswich, MA 78

54. Map showing percent effective impervious area, by subbasin (1991 land use), for subbasins upstream from the South Middleton streamgage, Ipswich, MA.

55. Graphs showing flow-duration curves of daily mean streamflow at $(A)$ reach 1 , Maple Meadow Brook at Route 38, Wilmington, $(B)$ reach 8, Ipswich River at Mill Street near Reading, $(C)$ reach 5, Lubbers Brook above Route 38, Wilmington, $(D)$ reach 13, Martins Brook above mouth, North Reading, and $(E)$ reach 19, Ipswich River at South Middleton streamgage in the Ipswich River Basin developed from long-term (1961-1995) simulations with 1989-1993 withdrawals (original baseline withdrawals), updated withdrawals for the towns of Reading and Wilmington (updated baseline withdrawals), and no withdrawals.

56. Graphs showing flow-duration curves of daily mean streamflow at $(A)$ reach 34 , Boston Brook above mouth, Middleton, $(B)$ reach 35, Ipswich River above Nichols Brook, Middleton, $(C)$ reach 28, Ipswich River at Maple Street, Middleton, $(D)$ reach 27, Middleton Pond Brook, Middleton, $(E)$ reach 19, Ipswich River at South Middleton streamgage, and $(F)$ reach 56, Ipswich River at Ipswich streamgage in the Ipswich River Basin developed from long-term (1961-1995) simulations with 1991 land use and potential land use at buildout

57. Graphs showing flow-duration curves of daily mean streamflow at $(A)$ reach 5 , Lubbers Brook above Route 38, Wilmington, $(B)$ reach 2, Maple Meadow Brook above mouth, Wilmington, $(C)$ reach 2, Mapple Meadow Brook above mouth (no flow from upstream reach), and $(D)$ reach 19, Ipswich River at South Middleton streamgage in the Ipswich River Basin developed from long-term (1961-1995) simulations with 1991 land use and 1991 land use with effective impervious area for each urban land-use category reduced by 50 percent to simulate low-impactdevelopment retrofits

58. Graphs showing flow-duration curves of daily mean streamflow at $(A)$ reach 17, Wills Brook, North Reading, $(B)$ reach 49, Idlewild Brook, Hamilton, $(C)$ reach 53, Howlett Brook, Topsfield, and (D) reach 19, Ipswich River at South Middleton streamgage in the Ipswich River Basin developed from long-term (1961-1995) simulations with updated baseline withdrawals, withdrawals reduced by scaled-up data from Massachusetts Department of Conservation and Recreation waterconservation pilot programs, withdrawals reduced by 20 percent, and no withdrawals

59. Graphs showing flow-duration curves of daily mean streamflow and mean daily-flow hydrographs from long-term (1961-1995) local-scale simulations of runoff from 100-acre parcels of undeveloped (forest) land and conventionally laid-out developed (low-density residential, high-density residential, and commercial) land $(A)$ overlying till and $(B)$ overlying sand and gravel with model-calibrated effective impervious area in the Ipswich River Basin, MA.

60. Graph showing mean annual water budgets for forested and developed hydrologic response units simulated in the Ipswich River Basin, MA 
61. Graphs showing flow-duration curves of daily mean streamflow from long-term (1961-1995) local-scale simulations of runoff from 100-acre parcels of conventionally laid-out (uniform) $(A)$ commercial development, $(B)$ high-density development overlying sand and gravel, $(C)$ high-density residential development overlying till, (D) low-density residential development overlying sand and gravel, and (E) low-density residential development overlying till with various amounts of effective impervious area (EIA) in the Ipswich River Basin, MA.

62. Graphs showing $(A)$ Median 1-day and 7-day high flows, $(B)$ median 1-day low flows, and $(C)$ median 7-day low flows from long-term (1961-1995) simulations of runoff from 100-acre parcels of conventionally laid out (uniform) development with various amounts of effective impervious area in the Ipswich River Basin, MA

63. Graphs showing ratios of the magnitudes of simulated daily peak flows for (A) commercial (developed) and forest overlying sand and gravel (undeveloped) land use, and (B) commercial (developed) and forest overlying till (undeveloped) land use as a function of recurrence interval and the amount of effective impervious area in the Ipswich River Basin, MA

64. Graphs showing flow-duration curves of daily-mean streamflow from long-term (1961-1995) simulations of runoff from 100-acre parcels of conventionally laid out (uniform) and cluster development with varying amounts of EIA in the developed part of the parcel for $(A)$ high-density residential overlying sand and gravel, $(B)$ high-density residential overlying till, $(C)$ low-density residential overlying sand and gravel, and $(D)$ low-density residential overlying till, Ipswich River Basin, MA. 


\section{Tables}

1. Concentrations of nutrients, dissolved metals, and total petroleum hydrocarbons in samples collected at water-table elevations from three multilevel samplers installed at the Silver Lake beach parking lot at Wilmington, MA, 2005-07.

2. Concentrations of nutrients, dissolved and total metals, and total petroleum hydrocarbons in quality-control and corresponding environmental samples collected at the Silver Lake beach parking lot and the Silver Lake Avenue runoff site in Wilmington, MA, and Whipple Annex and Town Hall roof-runoff sites in Ipswich, MA, 2005-07

3. Specific conductance, dissolved oxygen concentrations, and $\mathrm{pH}$ profiles in samples from multilevel samplers \#1, \#2, and \#3, in the Silver Lake beach parking lot, Wilmington, MA, July 6, 2005, to June 19, 2007.

4. Concentrations of nutrients, total metals, total petroleum hydrocarbons, total coliform bacteria, and E. coli in samples collected at the Silver Lake Avenue runoff site in Wilmington, MA, 2005-07

5. Estimated loads of nutrients, total metals, total petroleum hydrocarbons, total coliform bacteria, and E. coli in samples collected at the Silver Lake Avenue runoff site in Wilmington, MA, 2005-07.

6. Characteristics of five selected storms and runoff from the rubber roof on Town Hall and from the green roof on Whipple Annex, Ipswich, MA, 2007-08.

7. Concentrations of nutrients, total metals, and total petroleum hydrocarbons in runoff from the Town Hall and Whipple Annex roofs, and bulk precipitation, Ipswich, MA, 2007-08

8. Description of scenarios simulated with the Hydrological Simulation Program-FORTRAN precipitation runoff model of the Ipswich River Basin, Ipswich, MA71

9. Changes to the Wilmington, MA, water-supply system for the updated baseline simulation

10. Regionalized zoning codes for developable areas grouped by land-use categories used to construct the land use at buildout data layer for the Hydrological Simulation Program-FORTRAN model.

11. Land use in 1991 and potential land use at buildout in the Ipswich River Basin, MA.....77

12. Hypothetical water-use reductions obtained by scaling up the results from four water-conservation pilot projects conducted by the Massachusetts Department of Conservation and Recreation for towns that withdraw water from the Ipswich River Basin, MA.

13. Land-use distribution used in local-scale simulations for 100 -acre parcels, conducted with the calibrated Hydrological Simulation Program-FORTRAN model of the Ipswich River Basin, MA

14. Flow statistics for long-term (1961-1995) simulations with original baseline (1989-1993) withdrawals and updated baseline withdrawals for the towns of Reading and Wilmington (scenario LID_LT-upDem) at selected subbasins in the Ipswich River Basin, MA

15. Flow statistics for long-term (1961-1995) simulations with 1991 land use and potential land use at buildout (scenario LID_LT-build) at selected subbasins in the Ipswich River Basin, MA.

16. Flow statistics for long-term (1961-1995) simulations with 1991 land use and 1991 land use with effective impervious area reduced by 50 percent to represent low-impact-development retrofits (scenario LID_LT-retrofit) at selected subbasins in the Ipswich River Basin, MA. 
Table 17. Flow statistics for long-term (1961-1995), local-scale simulations of runoff from 100acre parcels with various combinations of undeveloped and developed land uses and amounts of effective impervious area.

\section{Conversion Factors, Datum, and Abbreviations}

Inch/Pound to SI

\begin{tabular}{lcl}
\hline \multicolumn{1}{c}{ Multiply } & By & \multicolumn{1}{c}{ To obtain } \\
\hline inch (in.) & Length & \\
inch (in.) & 2.54 & centimeter $(\mathrm{cm})$ \\
foot (ft) & 25.4 & millimeter $(\mathrm{mm})$ \\
mile (mi) & 0.3048 & meter $(\mathrm{m})$ \\
yard (yd) & 1.609 & kilometer $(\mathrm{km})$ \\
\hline & 0.9144 & meter $(\mathrm{m})$ \\
\hline acre & Area & \\
acre & 4,047 & square meter $\left(\mathrm{m}^{2}\right)$ \\
acre & 0.4047 & hectare $($ ha) \\
square foot $\left(\mathrm{ft}^{2}\right)$ & 0.004047 & square kilometer $\left(\mathrm{km}^{2}\right)$ \\
square foot $\left(\mathrm{ft}^{2}\right)$ & 929.0 & square centimeter $\left(\mathrm{cm}^{2}\right)$ \\
square inch $\left(\mathrm{in}^{2}\right)$ & 0.09290 & square meter $\left(\mathrm{m}^{2}\right)$ \\
square mile $\left(\mathrm{mi}^{2}\right)$ & 6.452 & square centimeter $\left(\mathrm{cm}^{2}\right)$ \\
square mile $\left(\mathrm{mi}^{2}\right)$ & 259.0 & hectare $($ ha) \\
\hline & 2.590 & square kilometer $\left(\mathrm{km}^{2}\right)$ \\
\hline gallon $($ gal) & Volume & \\
gallon $($ gal) & 3.785 & liter $(\mathrm{L})$ \\
cubic foot $\left(\mathrm{ft}^{3}\right)$ & 0.003785 & cubic meter $\left(\mathrm{m}^{3}\right)$ \\
\hline & 0.02832 & cubic meter $\left(\mathrm{m}^{3}\right)$ \\
\hline cubic foot per second $\left(\mathrm{ft}{ }^{3} / \mathrm{s}\right)$ & Flow rate & \\
million gallons per day $(\mathrm{Mgal} / \mathrm{d})$ & 0.02832 & cubic meter per second $\left(\mathrm{m}^{3} / \mathrm{s}\right)$ \\
inch per hour $(\mathrm{in} / \mathrm{h})$ & 0.04381 & cubic meter per second $\left(\mathrm{m}^{3} / \mathrm{s}\right)$ \\
\hline ounce, avoirdupois $(\mathrm{oz})$ & 0.0254 & meter per hour $(\mathrm{m} / \mathrm{h})$ \\
pound, avoirdupois $(\mathrm{lb})$ & 28.35 & kilogram $(\mathrm{kg})$ \\
\hline
\end{tabular}

Temperature in degrees Celsius $\left({ }^{\circ} \mathrm{C}\right)$ may be converted to degrees Fahrenheit $\left({ }^{\circ} \mathrm{F}\right)$ as follows:

${ }^{\circ} \mathrm{F}=\left(1.8 x^{\circ} \mathrm{C}\right)+32$

Vertical coordinate information is referenced to the North American Vertical Datum of 1988 (NAVD 88).

Horizontal coordinate information is referenced to the North American Datum of 1983 (NAD 83).

Altitude, as used in this report, refers to distance above the vertical datum.

Specific conductance is given in microsiemens per centimeter at 25 degrees Celsius $(\mu \mathrm{S} / \mathrm{cm}$ at $25^{\circ} \mathrm{C}$.

Concentrations of chemical constituents in water are given either in milligrams per liter $(\mathrm{mg} / \mathrm{L})$ or micrograms per liter $(\mu \mathrm{g} / \mathrm{L})$. 


$\begin{array}{ll}\text { ABBREVIATIONS AND ACRONYMS } \\ \alpha & \text { Accepted statistical significance level } \\ \mathrm{Cd} & \text { Cadmium } \\ \mathrm{Cr} & \text { Chromium } \\ \mathrm{Cu} & \text { Copper } \\ \text { EIA } & \text { Effective Impervious Area } \\ \text { HRU } & \text { Hydrologic Response Unit } \\ \text { HSPF } & \text { Hydrologic Simulation Program-FORTRAN } \\ \text { IMPLND } & \text { HSPF Impervious-area Land Element } \\ \text { LID } & \text { Low-impact development } \\ \text { MDCR } & \text { Massachusetts Department of Conservation and Recreation } \\ \text { MLS } & \text { Multilevel Sampler } \\ \text { MPN } & \text { Most probable number } \\ \text { MWRA } & \text { Massachusetts Water Resources Authority } \\ \text { NEIA } & \text { Noneffective Impervious Area } \\ \text { Ni } & \text { Nickel } \\ \text { Pb } & \text { Lead } \\ \text { PERLND } & \text { HSPF pervious-area Land Element } \\ \text { RCHRES } & \text { HSPF stream or reservoir reach } \\ \text { RPD } & \text { Relative percent difference } \\ \text { TPH } & \text { Total petroleum hydrocarbons } \\ \text { USEPA } & \text { U.S. Environmental Protection Agency } \\ \text { USGS } & \text { U.S. Geological Survey } \\ \text { Zn } & \text { Zinc } \\ \end{array}$




\title{
Effects of Selected Low-Impact-Development (LID) Techniques on Water Quality and Quantity in the Ipswich River Basin, Massachusetts: Field and Modeling Studies
}

\author{
By Marc J. Zimmerman, Jeffrey R. Barbaro, Jason R. Sorenson, and Marcus C. Waldron
}

\section{Abstract}

During the months of August and September, flows in the Ipswich River, Massachusetts, dramatically decrease largely due to groundwater withdrawals needed to meet increased residential and commercial water demands. In the summer, rates of groundwater recharge are lower than during the rest of the year, and water demands are higher. From 2005 to 2008, the U.S. Geological Survey, in a cooperative funding agreement with the Massachusetts Department of Conservation and Recreation, monitored small-scale installations of low-impactdevelopment (LID) enhancements designed to diminish the effects of storm runoff on the quantity and quality of surface water and groundwater. Funding for the studies also was contributed by the U.S. Environmental Protection Agency's Targeted Watersheds Grant Program through a financial assistance agreement with Massachusetts Department of Conservation and Recreation. The monitoring studies examined the effects of (1) replacing an impervious parking lot surface with a porous surface on groundwater quality, (2) installing rain gardens and porous pavement in a neighborhood of 3 acres on the quantity and quality of stormwater runoff, and (3) installing a 3,000 -square foot $\left(\mathrm{ft}^{2}\right)$ green roof on the quantity and quality of stormwater runoff. In addition, the effects of broad-scale implementation of LID techniques, reduced water withdrawals, and water-conservation measures on streamflow in large areas of the basin were simulated using the U.S. Geological Survey's Ipswich River Basin model.

From June 2005 to 2007, groundwater quality was monitored at the Silver Lake town beach parking lot in Wilmington, MA, prior to and following the replacement of the conventional, impervious-asphalt surface with a porous surface consisting primarily of porous asphalt and porous pavers. Changes in the concentrations of the water-quality constituents, phosphorus, nitrogen, cadmium, chromium, copper, lead, nickel, zinc, and total petroleum hydrocarbons, were monitored. Increased infiltration of precipitation did not result in discernible increases in concentrations of these potential groundwater contaminants. Concentrations of dissolved oxygen increased slightly in groundwater profiles following the removal of the impervious asphalt parking lot surface.

In Wilmington, MA, in a 3-acre neighborhood, stormwater runoff volume and quality were monitored to determine the ability of selected LID enhancements (rain gardens and porous paving stones) to reduce flows and loads of the above constituents to Silver Lake. Flow-proportional water-quality samples were analyzed for nutrients, metals, total petroleum hydrocarbons, and total-coliform and Escherichia coli bacteria. In general, when all storms were considered, no substantial decreases were observed in runoff volume as a result of installing LID enhancements. However, the relation between rainfall and runoff did provide some insight into how the LID enhancements affected the effective impervious area for the neighborhood. A decrease in runoff was observed for storms of 0.2 inches (in.) or less of precipitation, which indicated a reduction in effective impervious area from approximately 10 percent to about 4.5 percent for the 3 -acre area. Water-quality-monitoring results were inconclusive; there were no statistically significant differences in concentrations or loads when the pre- and post-installation-period samples were compared. Three factors were probably most important in minimizing differences: (1) the small decrease in effective impervious area, (2) the differences in the size of storms sampled for water-quality constituents before and after installation of the infiltration enhancing measures, and (3) small sample sizes.

In a third field study, the characteristics of runoff from a vegetated "green" roof and a conventional, rubber-membrane roof were compared. The amount of precipitation and the length of the antecedent dry period were the two primary factors affecting the green roof's water-storage capacity. The green roof retained more than 50 percent of the precipitation from storms with 0.04 to $1.0 \mathrm{in}$. of rain. Approximately 95 percent of the precipitation from one storm of nearly 2 in. was retained by the green roof. On the rubber-membrane roof, only a small, shallow puddle of insubstantial volume ever remained after a storm. Bulk precipitation from 10 storms was monitored for the same constituents (nutrients, metals, and total petroleum hydrocarbons) as the roof runoff, and the results were compared with those for roof-runoff samples. 
The use of fertilizers to help establish the vegetation during the study probably distorted any effect the plants and growing medium may have had on the retention of target analytes. As a result of the fertilizer and growing medium chemistry, median concentrations of total nitrogen, total phosphorus, cadmium, copper, and nickel in runoff from the green roof were greater than in the runoff from the conventional roof or in bulk precipitation. Concentrations of lead and zinc were greater in runoff from the conventional roof, probably a result of passage through the old, metal drainpipes.

Simulations of the effects of LID on streamflow in the Ipswich River Basin were conducted with a previously calibrated Hydrological Simulation Program-FORTRAN (HSPF) precipitation-runoff model. Simulations were conducted at multiple spatial scales to evaluate the effects of (1) updated water withdrawals for the towns of Reading and Wilmington; (2) potential land-use changes at buildout (potential future development); (3) effective impervious area reductions upstream from the South Middleton streamgage to represent the effects of widespread implementation of LID retrofit techniques; (4) basin-scale water withdrawal reductions scaled up (expanded to the town level) from water-conservation pilot programs conducted by the Massachusetts Department of Conservation and Recreation; and (5) land-use change and LID techniques at a local scale, which is smaller than the HSPF subbasin. Effects on streamflow generally were evaluated by comparing results of two or more related simulations for selected reaches in the basin; thus, relative rather than absolute changes in simulated flow were the focus of the assessment. Simulations indicated that reduced withdrawals for the towns of Reading and Wilmington led to substantially higher medium and low flows in most of the reaches upstream from the South Middleton streamgage. Simulations of water-conservation measures resulted in negligible effects on streamflow.

Overall, simulations indicated that spatial scale is an important factor in determining the effects of land-use change and LID practices on streamflow. Potential land-use changes at buildout had modest (percent differences of less than 20 percent) effects on streamflow in most subbasins because relatively little land in the basin was available for development (about 17 percent); moreover, most of the available open land is zoned for low-density residential development, and this land-use category was simulated to contain relatively little effective impervious area and to be similar hydrologically to the forested land in place prior to development. Results of the simulations conducted to evaluate widespread effective impervious area reductions upstream from the South Middleton streamgage indicated that the percentage of urban land use and associated effective impervious area was too small for a 50-percent reduction of effective impervious area to appreciably affect streamflow (percent differences of less than 20 percent) in most subbasins. In contrast, the results of the hypothetical local-scale simulations indicated that for smaller streams, where the percentage of urban land use and associated effective impervious area in the drainage area may be substantially higher, land-use change, development patterns, and LID practices potentially have much greater effects on streamflow.

Modeling results also indicated that LID was potentially most beneficial for minimizing streamflow alteration when applied to dense urban development, largely because larger tracts of effective impervious area were available for reduction than were available for other land-use categories. For example, commercial-industrial-transportation land use is composed of 37 percent pervious area and 63 percent effective impervious area in the HSPF model, whereas low-density residential area is composed of 97.5 percent pervious area and only 2.5 percent effective impervious area.

Field and modeling studies concurred in the assessment that LID enhancements would likely have the greatest effect on decreasing stormwater runoff when broadly applied to highly impervious urban areas. A measurable effect for small rainfall events (less than 0.25 inch) was determined in the small, highly pervious area that was monitored in this study, but the volume difference was not great.

\section{Introduction}

In 1997, the environmental organization, American Rivers, placed the Ipswich River, located in northeastern Massachusetts (fig. 1), on its list of 20 most-endangered rivers because of water withdrawals and development. American Rivers placed the Ipswich River on the list again in 2003 because of the extent of groundwater withdrawals and expansive water use. The river has, on numerous occasions, run dry in several places during periods of maximum water withdrawals. In addition to use within the basin, water is exported for supply and wastewater treatment outside the basin, which contributes to stress on basin water resources. Short-term, stopgap measures such as mandatory water-use bans do not seem sufficient to guarantee adequate water supplies for human consumption and maintenance of aquatic habitat. Periods of extremely reduced flow have detrimental effects on streamwater quality, such as low concentrations of dissolved oxygen, elevated temperatures, algal blooms, and fish die-offs. Unless more effective means are implemented, further development in the Ipswich River Basin may continue to threaten this river. Recently, the towns of Wilmington and Reading have entered into water-supply agreements to have the Massachusetts Water Resources Authority (MWRA) provide water from sources outside of the Ipswich River Basin, thereby diminishing some of the demand from sources in the basin. The long-term effects on Ipswich River Basin streamflow of using this alternate water supply are not yet determined.

With increases in water demand for residential and commercial development in the Ipswich River Basin likely to continue for the foreseeable future, new approaches are called for to sustain the river's flow throughout the year. Wide-scale application of water-conservation measures and redirecting runoff to infiltrate into the ground, rather than into storm 


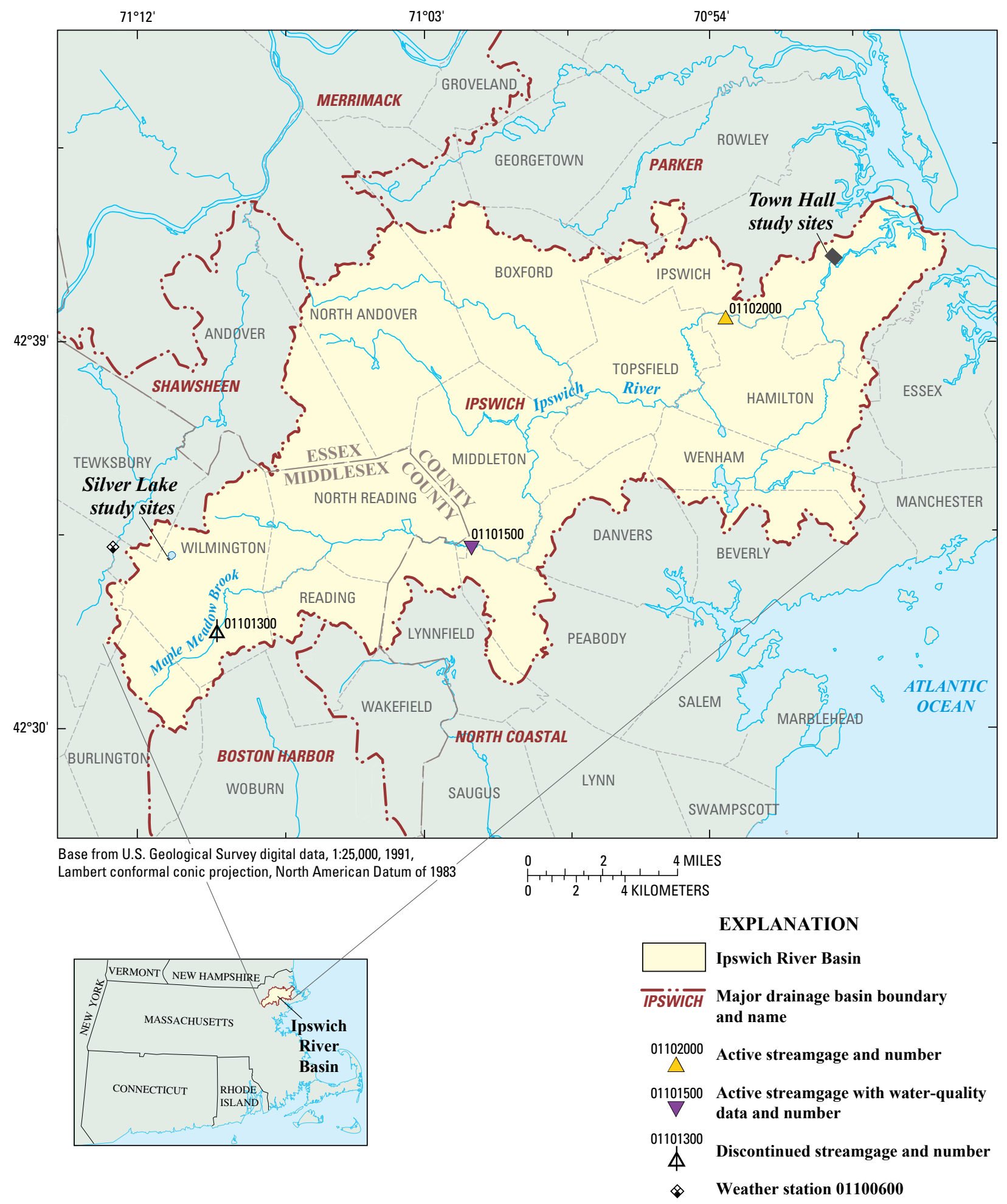

Figure 1. Location of streamgages, wells, and weather station in the Ipswich River Basin, MA. 
drains and away from the area where the rain falls, are among potential means for relieving or decreasing the stress on the river. To this end, USGS, through a cooperative funding agreement with the Massachusetts Department of Conservation and Recreation (MDCR), conducted studies to (1) quantify LID benefits and water-conservation techniques for decreasing runoff, increasing stormwater infiltration to groundwater, and improving streamflow; and (2) quantify these benefits on a basin-wide scale using computer simulation. Funding for the studies also was contributed by the U.S. Environmental Protection Agency's (USEPA) Targeted Watersheds Grant Program through a financial assistance agreement with MDCR. Additional funding for some of the infrastructural work described here came from the Town of Wilmington and in-kind support came from the Town of Ipswich, MA.

\section{Applications of Low-Impact-Development (LID) Principles and Techniques}

Conventional urban, suburban, commercial, and recreational development creates increased impervious surface areas through new roads, roofed structures, parking lots, driveways, and sidewalks.

Increasing amounts of impervious cover are generally associated with modifications to natural hydrology, such as increased runoff volume and rate (Leopold, 1968). Moreover, the increased imperviousness also contributes to increased loads of contaminants to waterways (Grimm and others, 2008). Conventional stormwater-runoff management aims to convey runoff quickly and efficiently to a holding facility or to a stream, thus minimizing infiltration into groundwater and altering surface-water hydrology. The goal of low-impact development (LID) is the maintenance or restoration of pre-development hydrology by increasing runoff times and infiltration. LID distributes small-scale controls throughout a developed site or a site proposed for new development. Features implemented in the studies presented in this report are swales, rain gardens, bioretention cells, porous pavements, and green roofs. Swales are graded, vegetated depressions, frequently installed along roadsides where they enhance road-runoff infiltration into the local groundwater; existing curbs may be cut to channel water to the swale. Rain gardens are landscaped, low-lying areas with soil mixes designed to absorb and filter water; rain gardens are planted with water- and drought-tolerant vegetation; curbs may also be cut to direct road runoff into rain gardens. Bioretention cells, similar to, but often more highly engineered than rain gardens, may be lined with filter fabric. Vegetated, or green, roofs also serve to attenuate stormwater-runoff peaks and provide some filtration of potential contaminants in stormwater. A green roof replaces a conventional, sealed roof of asphalt, shingles, or membranes with an absorbent plant-growing medium; greenroof soil media and plants attenuate runoff by absorbing and transpiring rainfall.

\section{Previous Studies}

Numerous reports document the propensity for the Ipswich River to run dry in the summer; many of these reports are summarized by Zarriello and Ries (2000), who also describe a basin-wide hydrologic model (the Ipswich River Basin Model). Since that report was published, the USGS has produced additional reports, including Zarriello (2004, 2002a, b) and Armstrong and others (2001). The first three works extend the modeling study (Zarriello and Ries, 2000), upon which part of the present study is based, to explore additional watermanagement options; Armstrong and others (2001) describe stream habitat and use standard streamflow-estimating methods to determine aquatic habitat requirements.

Additional studies examine the effects of stream discharge in the Ipswich River Basin. Williams and others (2005) indicate that land use accounts for about 50 percent of the variability of streamwater-solute concentrations; thus, other undefined factors are also important. Crump and Hobbie (2005) consider temperature and variations in discharge as the best predictors of bacterial diversity.

Filoso and others (2004) use the hydrologic component of the Ipswich River Basin model developed by Zarriello and Ries (2000) to model nitrogen transport in the basin under various land-use scenarios. They found that nitrogen concentrations in the river increased with increasing proportions of urban land use in the basin.

Selbig and Bannerman (2008) compare runoff and water quality in adjacent, conventional and LID-enhanced residential basins in Cross Plains, Wisconsin, from 1999 to 2005. They found that the conventional basin annually discharged 1.3 to 9.2 times the volume discharged from the LID-enhanced basin. Selbig and Bannerman (2008) also determined that antecedent soil conditions (for example, percent saturation and freezing) and storm intensity affected the ability of the LID basin to retain runoff. A major feature of the LID basin was an infiltration basin that was the last feature used to treat runoff before it left the basin. Hood and others (2007) determined that LID techniques were most effective for small storms and dry antecedent conditions; they noted that, under all storm conditions that they studied, "LID [techniques] reduced [the] runoff depth and peak discharge." Dietz and Clausen (2008) found that runoff and export of nitrogen and phosphorus from a conventional development increased logarithmically over time, whereas runoff and export from a comparable, adjacent, LID development did not change from pre-development conditions.

\section{Purpose and Scope}

This report describes the results of studies monitoring the effects of selected LID techniques on the volume and quality of storm runoff. The report also presents the results of a series of modeling scenarios based on the theoretical widescale implementation of LID enhancements or reductions of water withdrawals throughout the Ipswich River Basin, as 
well as some simulations designed to assess the effects of LID enhancements on 100-acre parcels of land.

In the first part of this report, the effects of selected LID techniques on runoff water quality and quantity are evaluated. In Wilmington, MA, nutrient, dissolved-metal, and total petroleum hydrocarbon (TPH) concentrations in groundwater samples were determined before and after the installation of a new porous-pavement parking lot and other LID enhancements at Silver Lake Beach. Groundwater levels also were monitored. On the opposite side of Silver Lake, LID enhancements, including rain gardens and porous pavers were retrofitted in the small (3-acre) Silver Lake Avenue/Dexter Street neighborhood; runoff volume and concentrations of waterquality constituents (nutrients, total metals, coliform bacteria, and TPH) were monitored prior to and following the installation of these LID enhancements. In Ipswich, MA, a 3,000- $\mathrm{ft}^{2}$ vegetated, green roof was installed on an existing building that was being converted into senior housing; the volume of, and water-quality constituents (nutrients, total metals, and TPH) in, runoff from the green roof and a neighboring conventional, rubber-membrane roof are discussed.

The second part of this report describes simulations conducted using the calibrated Ipswich River Basin Hydrologic Simulation Program-FORTRAN (HSPF) model to evaluate the effects of various LID practices, land-use changes, and water-management activities on streamflow at multiple spatial scales. The Ipswich River Basin HSPF model simulates only streamflow. This portion of the report includes descriptions of simulation scenarios developed to address the issues listed above, the accompanying modifications made to the calibrated model, and discussions of simulation results. Model limitations and applicability of simulation results to evaluate streamflow alteration in the Ipswich River Basin also are discussed.

\section{Environmental Setting}

The 155-mi Ipswich River Basin drains into the Atlantic Ocean in northeastern Massachusetts; the maximum altitude in the headwaters area is about $110 \mathrm{ft}$ (NAVD 88). Wetlands account for about 21 percent of the basin's area. Areas of sand and gravel or of glacial till dominate the basin's surficial geology. Sand and gravel are concentrated most heavily in the headwaters and Coastal Plain reaches, and glacial till is present in the middle reaches of the basin. Land use upstream from the USGS South Middleton streamgage (01101500; fig. 1) is somewhat more residential (38 percent) than it is downstream (28 percent); upstream from the gage, forests and open space account for about 34 percent of the land use compared to 44 percent downstream from the gage (Zarriello and Ries, 2000; Sammel and others, 1964). The field studies in Wilmington took place in areas of sand and gravel, and the modeling study covered all geological settings within the study area.

The climate in the basin is humid. In general, precipitation is evenly distributed throughout the year with occasional extended dry periods in the middle to late summer. During summer and early fall of 2005, the basin had very little rain.

\section{Field Studies of Low-Impact- Development Techniques}

Three field studies of varying duration were conducted from 2005 to 2008. The Silver Lake Avenue runoff study and green roof runoff study required extended sampling periods due to the difficulty of predicting storms of adequate magnitude for sampling; that is, (1) sufficiently large storms did not materialize as forecast, or (2) storms forecast as too small for sampling developed into large storms that were not sampled.

\section{Porous Parking Lot Enhancements at Silver Lake Beach}

At Silver Lake Beach, Wilmington, MA, approximately one-half of the impervious-asphalt parking lot (figs. 2A, B), approximately $250 \mathrm{ft}$ long and $135 \mathrm{ft}$ wide, was replaced with a porous parking lot. The edge of the parking lot next to the sandy beach was approximately $135 \mathrm{ft}$ from the lake. The porous-surfaced parking lot features rain gardens, bioretention cells, and other pervious cover. The porous parking areas, 120 by $135 \mathrm{ft}$, consist of porous asphalt and pavers. The remaining half of the paved lot was replaced with impervious asphalt, bioretention cells, and rain gardens. The impervious section of the new parking lot was designed to drain toward the porous area and its bioretention cells. In the event that water volume should surpass the infiltration capability of the parking lot system, a drain pipe was installed to carry any surcharge to a grassy swale leading into the lake at the northwest corner of the beach.

The porous parking lot was not only intended to minimize runoff from the original, impervious parking lot into Silver Lake but also to serve as a demonstration and research project showing the lot's effectiveness at enhancing infiltration (Roy and Braga, 2009). To address concerns about whether replacing part of the impervious parking lot with porous material would lead to groundwater contamination from infiltrating contaminants that had dropped or spilled onto the parking lot's surface, the USGS analyzed the quality of the groundwater below the porous parking lot before and after installation.

The primary concern faced at Silver Lake Beach was the frequent closing of the swimming area because of high counts of bacteria. During the summers of 1998 to 2005, the beach was closed for at least 1 week each year because of high bacteria counts; the beach was closed for 5 weeks in 2004. Waterfowl, such as ducks and geese (fig. 3), were thought to be the source of the bacterial contamination (Jamie Magaldi, Wilmington Department of Public Works, oral commun., 2005). The main attractions to the area for the waterfowl, the lake proper notwithstanding, were two grassy, stormwater outfall areas bordering and running perpendicular to the beach and the food offered by beachgoers, in spite of signs telling people not to feed the ducks and geese. To discourage waterfowl from staying near the beach and to treat some stormwater runoff 

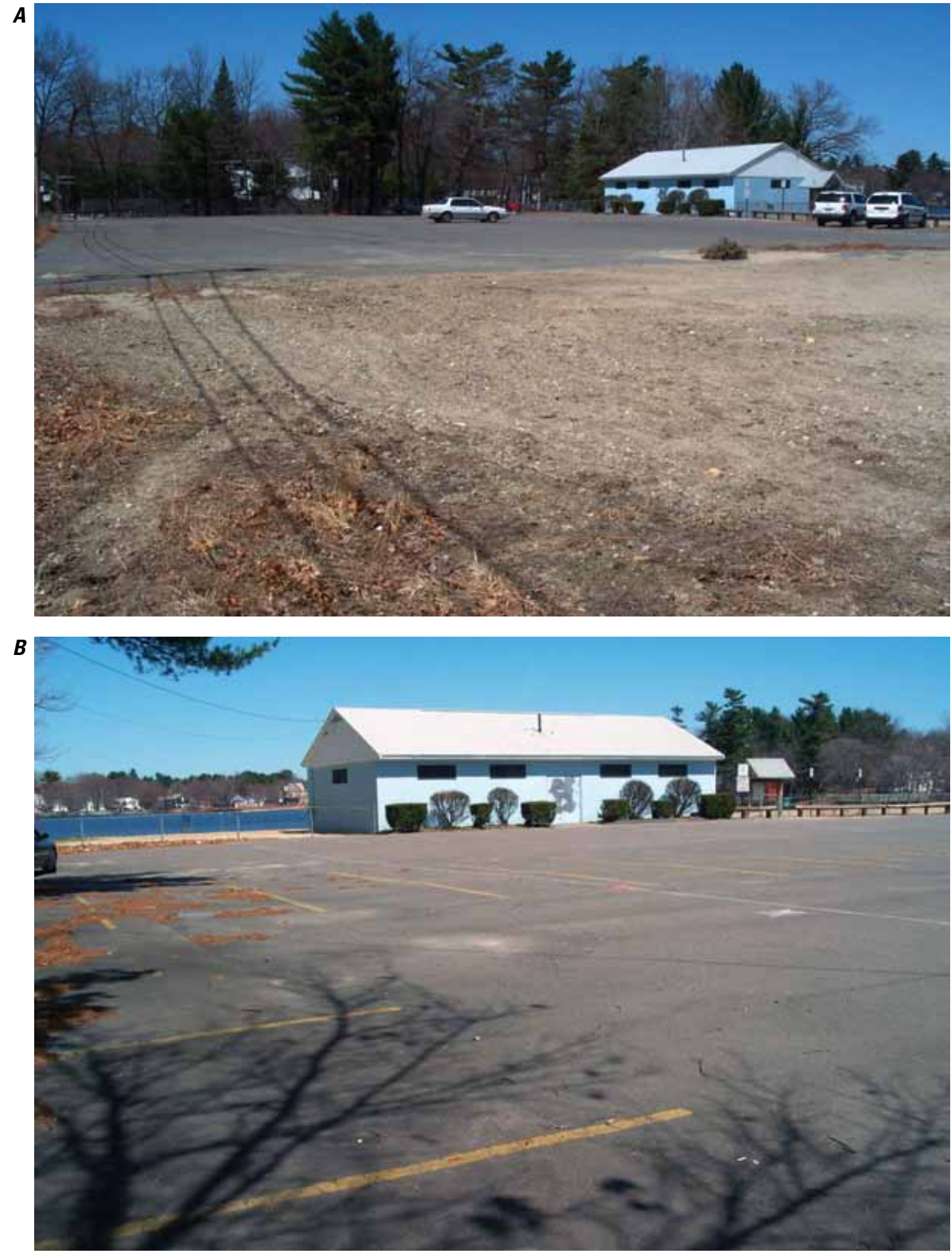

Figure 2. Views of Silver Lake Beach parking lot in Wilmington, MA, prior to renovation, (A) looking west and (B) looking north. 


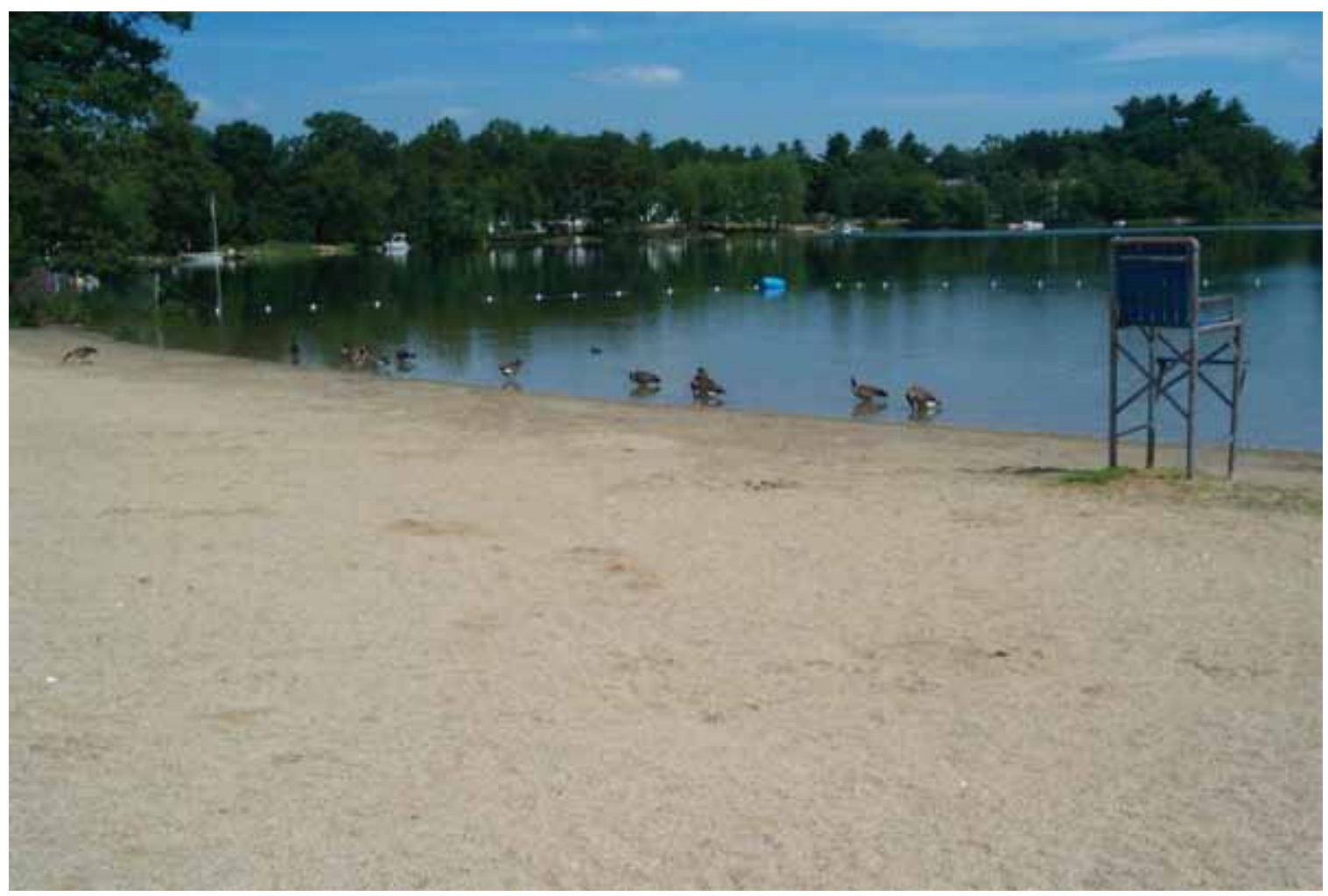

Figure 3. Water fowl feeding on Silver Lake Beach in Wilmington, MA, prior to installation of low-impactdevelopment features.

from the bordering neighborhood and the parking lot, the stormwater-outfall areas were converted into narrow swales with sufficient vegetation to prevent erosion and designed not to attract waterfowl. During the 2 years of this study that followed these changes, there were no beach closings due to high bacterial counts.

\section{Design of Low-Impact-Development Enhancements to Increase Infiltration}

The Massachusetts Department of Conservation and Recreation selected Geosyntec Consultants to design and oversee the installation of the porous parking lot at Silver Lake. Features of the U-shaped porous parking area include a central bioretention island, several rain gardens, porous paving stones in the parking spaces, and a porous asphalt drive (fig. 4). A 12-in. layer of crushed stone was installed under all porous surfaces to enhance storage and infiltration. The soils in the bioretention cells and rain gardens were designed to promote infiltration of stormwater runoff and to filter out sediment and nutrients. On the basis of infiltration tests conducted by Geosyntec Consultants at Silver Lake, the porous asphalt and pavers allowed water to infiltrate at a rate of 78 and $57 \mathrm{in} / \mathrm{h}$, respectively; water to the bioretention cells could infiltrate more than $20 \mathrm{in} / \mathrm{h}$ and to the rain gardens more than $12 \mathrm{in} / \mathrm{h}$ (Roy and Braga, 2009).

\section{Monitoring Approach}

To adequately monitor any changes in the concentrations of groundwater chemical constituents, it was necessary to understand the direction of regional and local groundwater movement. Therefore, surficial geology was studied and groundwater-flow direction determined to guide the design for monitoring water quality before installing water-qualitymonitoring wells on the site of the parking lot prior to its renovation.

\section{Regional and Local Groundwater Flow}

Silver Lake lies close to Lubbers Brook and near the topographic divide between the drainages to Lubbers Brook and the Shawsheen River. There is an intermittent surface outflow from the eastern side of the lake that runs under Rte. 38 before entering Lubbers Brook. The regional groundwaterflow direction in the vicinity of the parking lot was estimated from surface topography and available information about the distribution of surficial deposits (Sammel and others, 1964). On this basis, regional groundwater flow is approximately from northwest to southeast (fig. 5).

In June 2005, wells were drilled in the parking lot to monitor water levels and water quality. First, four waterlevel-monitoring wells, also known as observation wells, were installed to determine the local direction of groundwater flow under the parking lot and, thus, to aid in the siting of water-quality-monitoring wells. Elevations of all wells were 


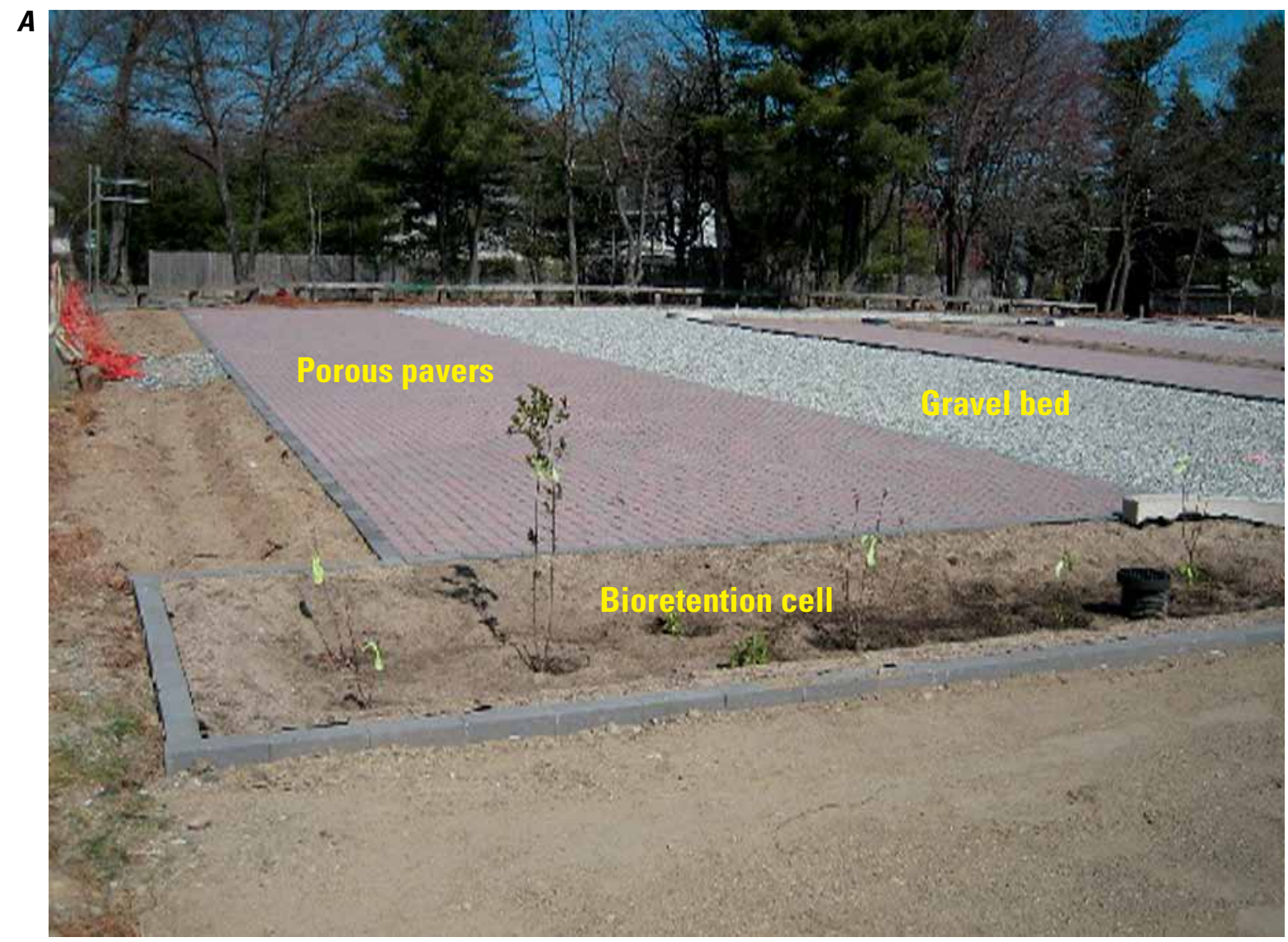

$\boldsymbol{B}$

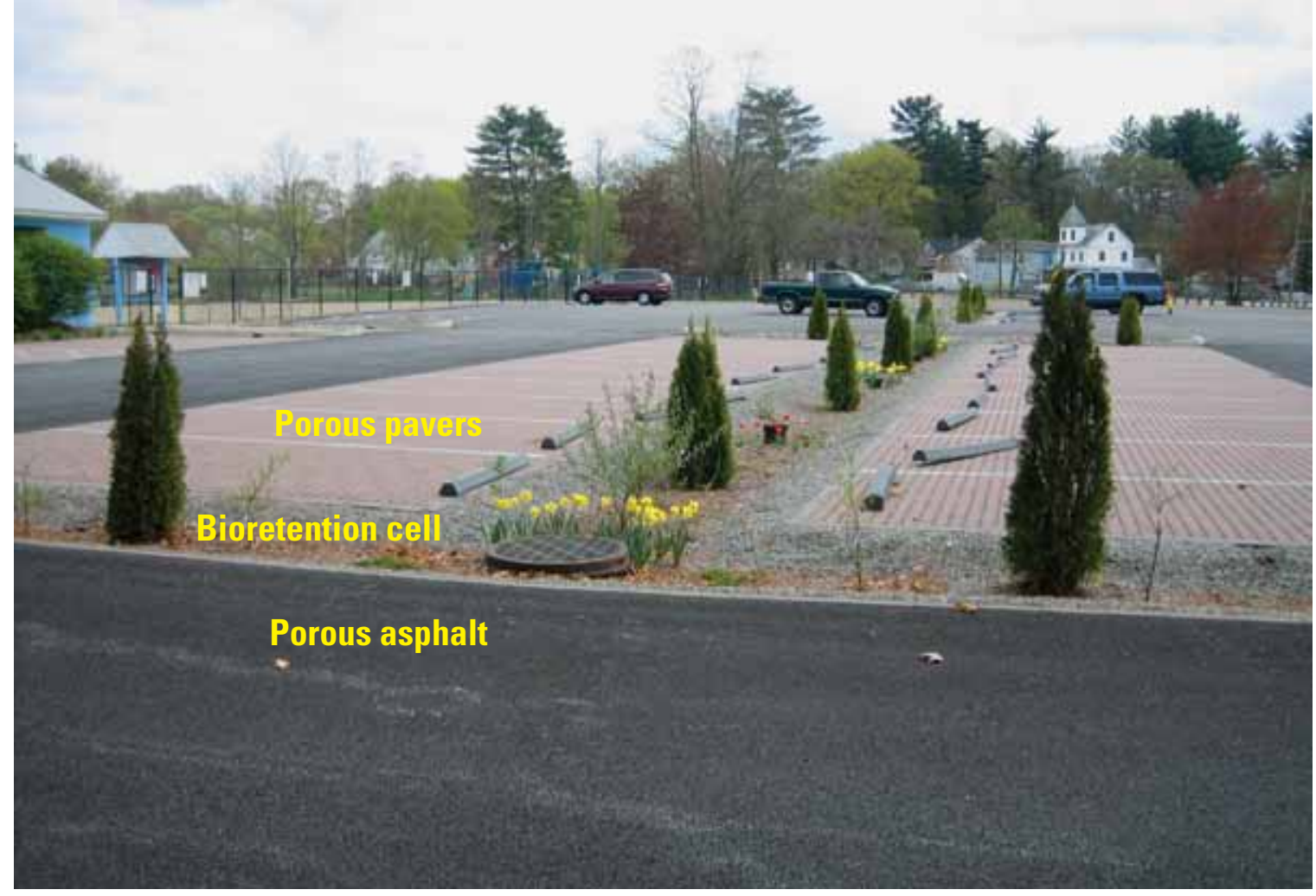

Figure 4. Views of $(A)$ partially completed porous parking lot at Silver Lake Beach, Wilmington, MA, showing bioretention cells, porous pavers, and gravel bed for porous asphalt and $(B)$ completely renovated parking lot. 


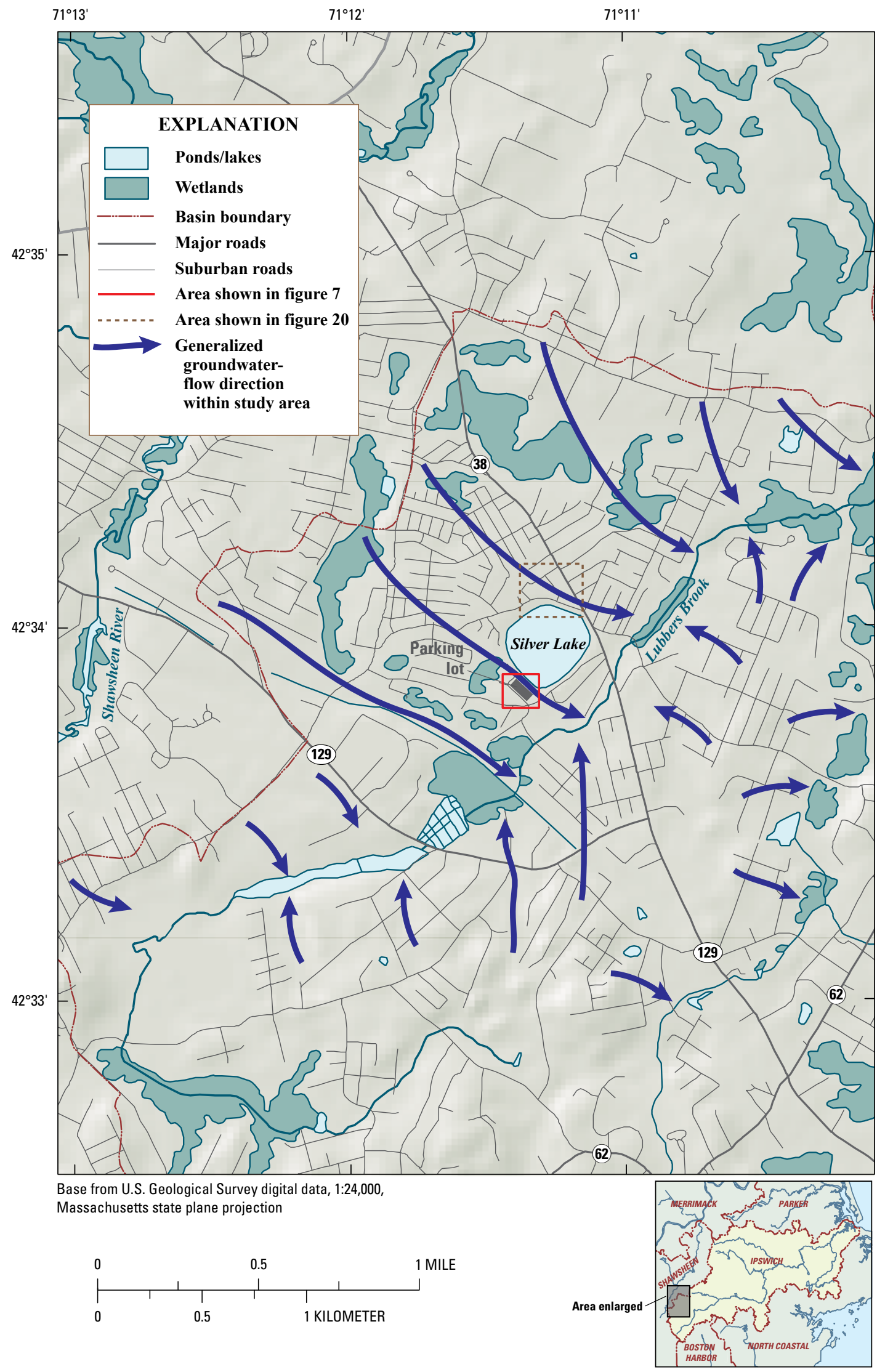

Figure 5. Generalized groundwater-flow direction in the vicinity of Silver Lake, Wilmington, MA. 
surveyed to enable comparisons of the water levels. The relatively flat water table indicated by the water-table altitudes in the observation wells resulted in some ambiguity about the precise direction of flow across the site. Two multilevel water-quality-sampling wells (MLSs) were originally planned, one upgradient and one downgradient from the parking lot with respect to groundwater-flow directions. Because of the relatively flat water table, a third MLS was added. Two of the three MLSs (MLS\#1 and MLS\#2) were installed at downgradient locations with the highest probability of observation of changes in water quality following installation of the porous pavement. The third MLS (MLS\#3) was installed on the northwest edge of the parking lot, at an upgradient location, to serve as a reference well for monitoring the water-quality characteristics of groundwater that might enter the parking-lot area from offsite. Each MLS was assembled with 13 sampling ports, 6 in. apart from each other (fig. 6), extending downward, starting near the observed water table at the time of installation.

\section{Water-Table Altitude and Water Quality}

During each site visit, field parameters (temperature, dissolved oxygen, $\mathrm{pH}$, and specific conductance) were measured with a Quanta ${ }^{\mathrm{TM}}$ multiparameter sonde from all ports in the multilevel samplers from which water could be drawn using a peristaltic pump. The sonde was calibrated using standard USGS protocols found in the National Field Manual for the Collection of Water-Quality Data (U.S. Geological Survey, variously dated). Starting at the highest sampling port and working downward into the well made it possible to identify, within approximately 6 in., the altitude of the water table- the altitude from which water-quality samples for nutrients (various chemical forms of nitrogen and phosphorus), dissolved metals (cadmium, copper, chromium, lead, nickel, and zinc), and total petroleum hydrocarbons were collected, also using methods described in the National Field Manual. After the samples were collected and processed, they were stored on ice at $4{ }^{\circ} \mathrm{C}$ until they were shipped to the USGS National Water Quality Laboratory (NWQL) for analysis.

From July through October 2005, five samples were collected within a few days after storms. But, the initial sampling results indicated that substantially more frequent sampling would be required to determine whether the samples were actually capturing recent stormwater; however, budget constraints would not allow for frequent sampling following individual storms. After the porous parking lot installation was completed in June 2006, a monthly sampling schedule was followed during the rest of the study. This sampling frequency was adequate to ensure that water recharged through the replaced parking lot would be monitored within the study duration because unsaturated-zone calculations indicated that water infiltration through the parking lot to the water table should occur within weeks of precipitation.

\section{Changes in Groundwater Quality Following the Installation of Low-Impact-Development Enhancements}

Water-level data for the observation wells during the study period indicate that groundwater moves in the same general direction (toward Lubbers Brook) as the surface water, thus flowing under the parking lot approximately in a westnorthwest to east-southeast direction (fig. 7). In addition, the data indicate that groundwater flows toward Silver Lake in a manner that would make MLS\#1, which is closer to the lake than MLS\#2 (the other downgradient sampling well), the best well from which to assess changes in water quality that result from recharge through the parking lot. In the summer of 2005, drought conditions caused well elevations to drop below the lake surface elevation (fig. 8). On occasion, the lake outlet may become blocked, causing the lake elevation to exceed the water-table altitude at MLS\#1, possibly slowing, but probably not reversing the flow of groundwater toward the lake; for example, in August 2006, the lake elevation exceeded the water table in the parking lot by about $1 \mathrm{ft}$. Other, more subtle, changes in flow direction may have gone undetected because of the monthly monitoring program.

The Wilcoxon rank-sum test was used to compare analyte concentrations ( $\alpha=0.05$ was used to define the likelihood of differences in distributions of the sample concentrations) at the three MLSs before and after the parking lot installation (table 1). The small number of samples (5 before and 12 after installation), however, made it difficult to draw robust statistical inferences; changes in reporting levels also complicated statistical analysis. Some analytes were detected only rarely, if at all, in some wells; these include dissolved nitrite, dissolved cadmium, dissolved lead. Where appropriate, following a recommendation of Helsel (2005a, b), values of one-half the detection level were substituted for nondetects in order to make some of these statistical comparisons.

Quality-control samples (one blank and two field replicates) were collected (table 2) during the study. Concentrations in the replicates were consistent with those in the environmental samples. With the exception of ammonia, low-level detections (nitrite, nickel, and zinc) in the blank sample are insignificant relative to the concentrations detected in the associated well, MLS\#3. Ammonia detections in the field samples were uncommon, indicating the blank may have been contaminated in the laboratory; moreover, both blank and environmental values were less than the reporting level. The occasional relative percent difference (RPD) value that exceeded 20 percent seems to have been random and not indicative of systematic excessive variability in the sample concentrations.

\section{Specific Conductance, Dissolved Oxygen, and pH}

The specific conductance profile data for MLS\#1 and MLS\#2 are similar in range (table 3). Most of the values range between 50 and $150 \mu \mathrm{S} / \mathrm{cm}$. For 2005, a year with very dry conditions, some of the values exceed $200 \mu \mathrm{S} / \mathrm{cm}$. In MLS\#1, 


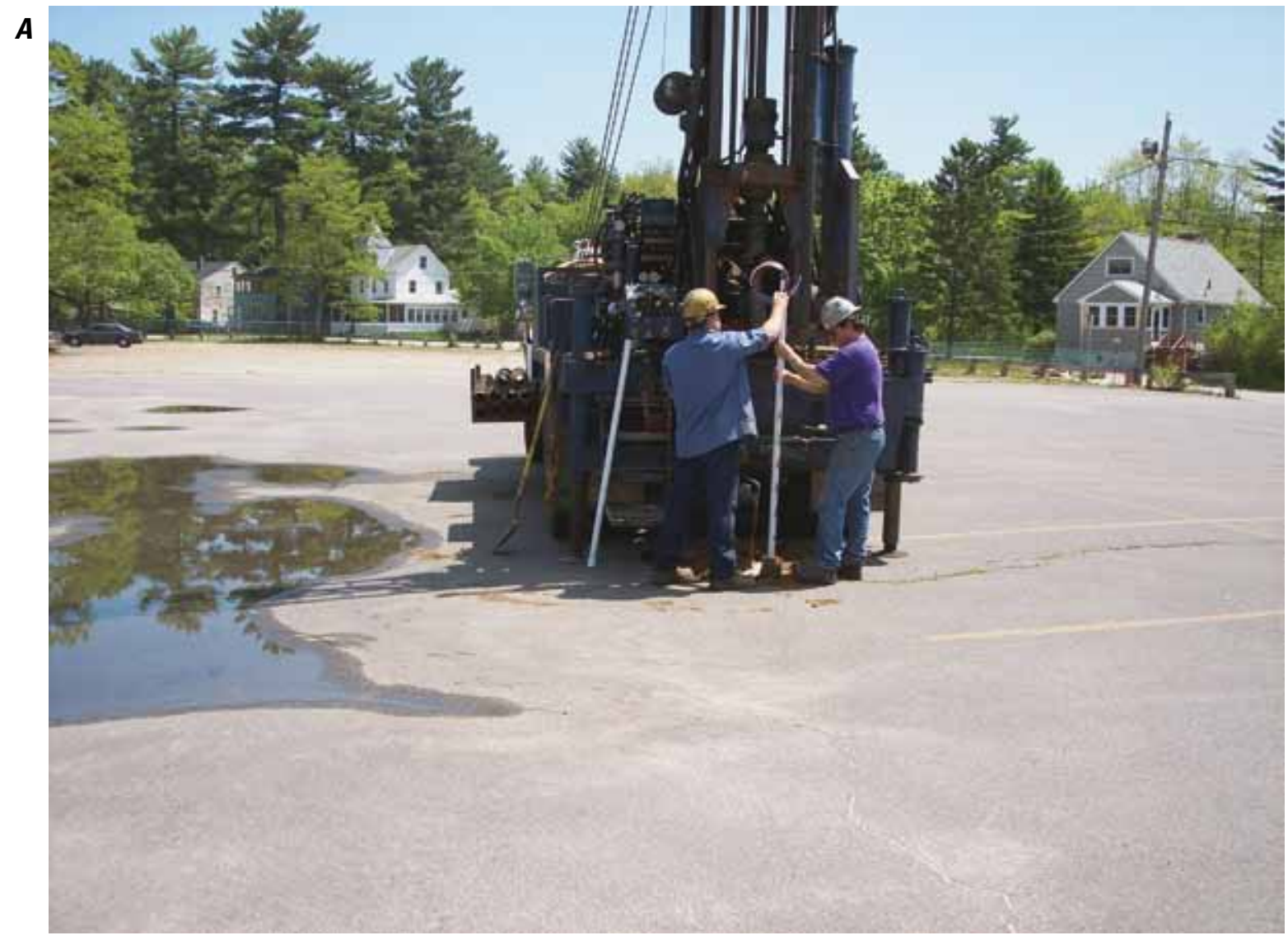

B

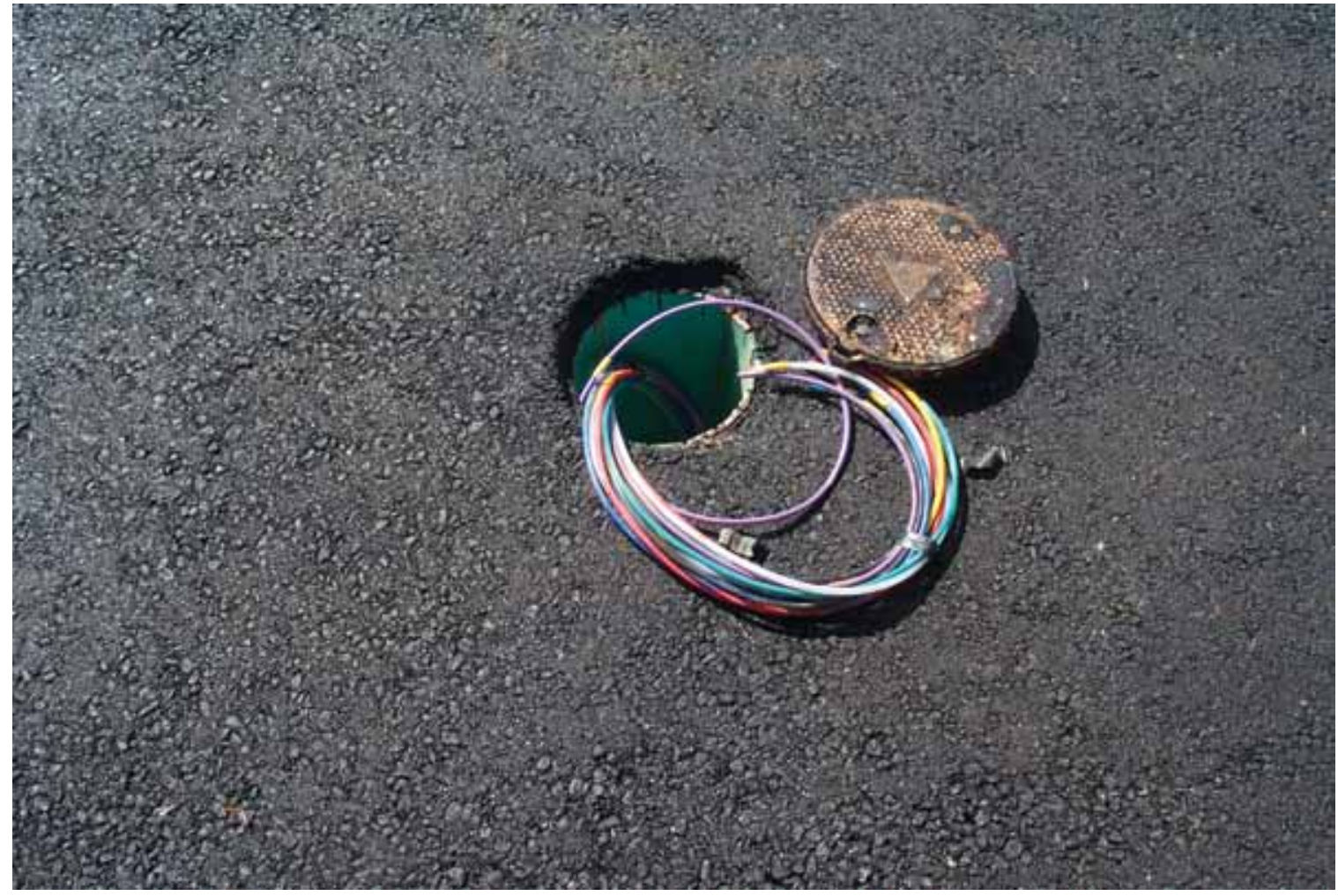

Figure 6. (A) U.S. Geological Survey well drillers installing multilevel samplers. Markings on the white PVC pipe are locations of the sampling ports and $(B)$ color-coded sampling tubes that lead to intake ports in multilevel samplers. 


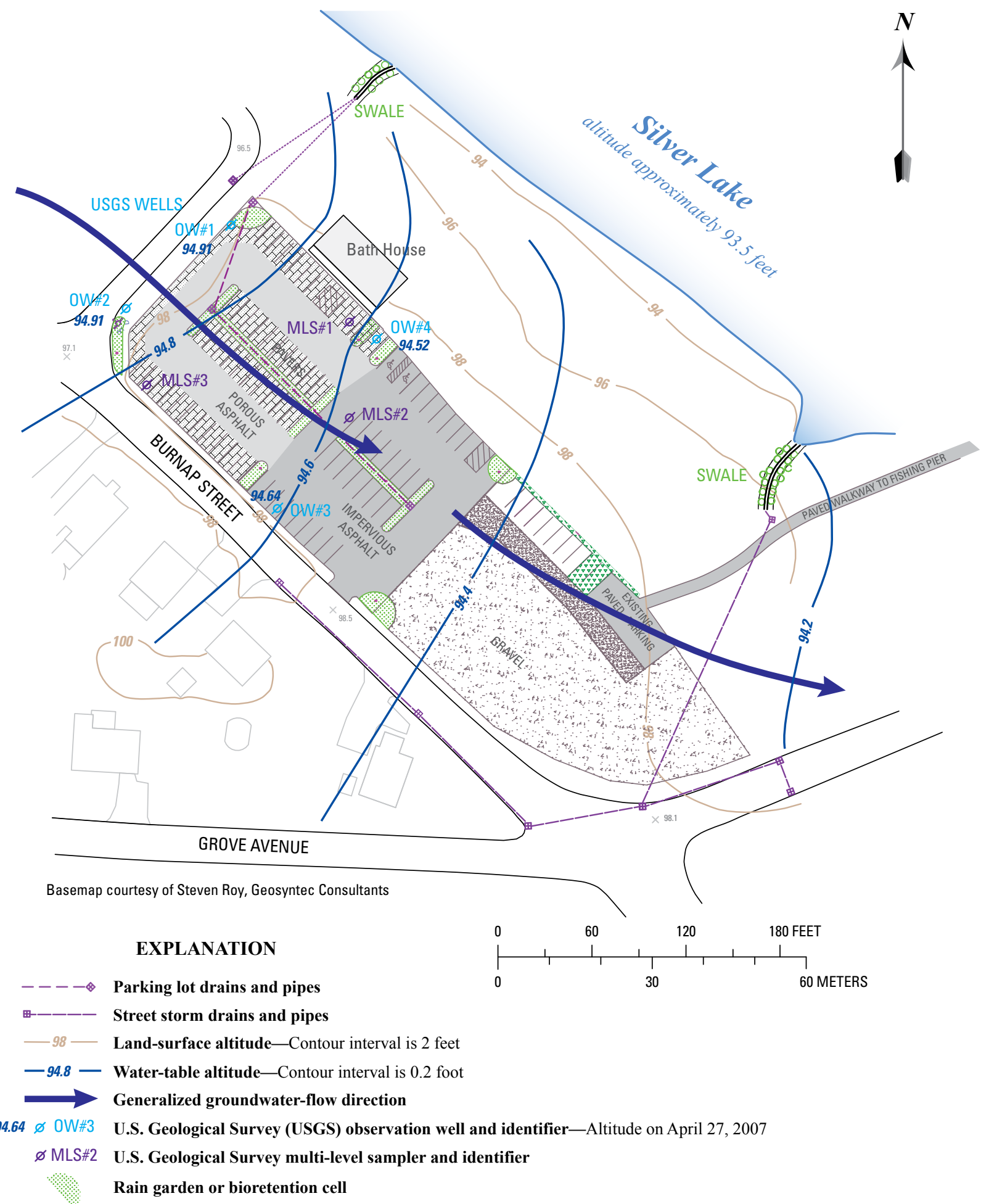

Figure 7. Features of Silver Lake Beach parking lot, Wilmington, MA, and generalized groundwater-flow direction. 


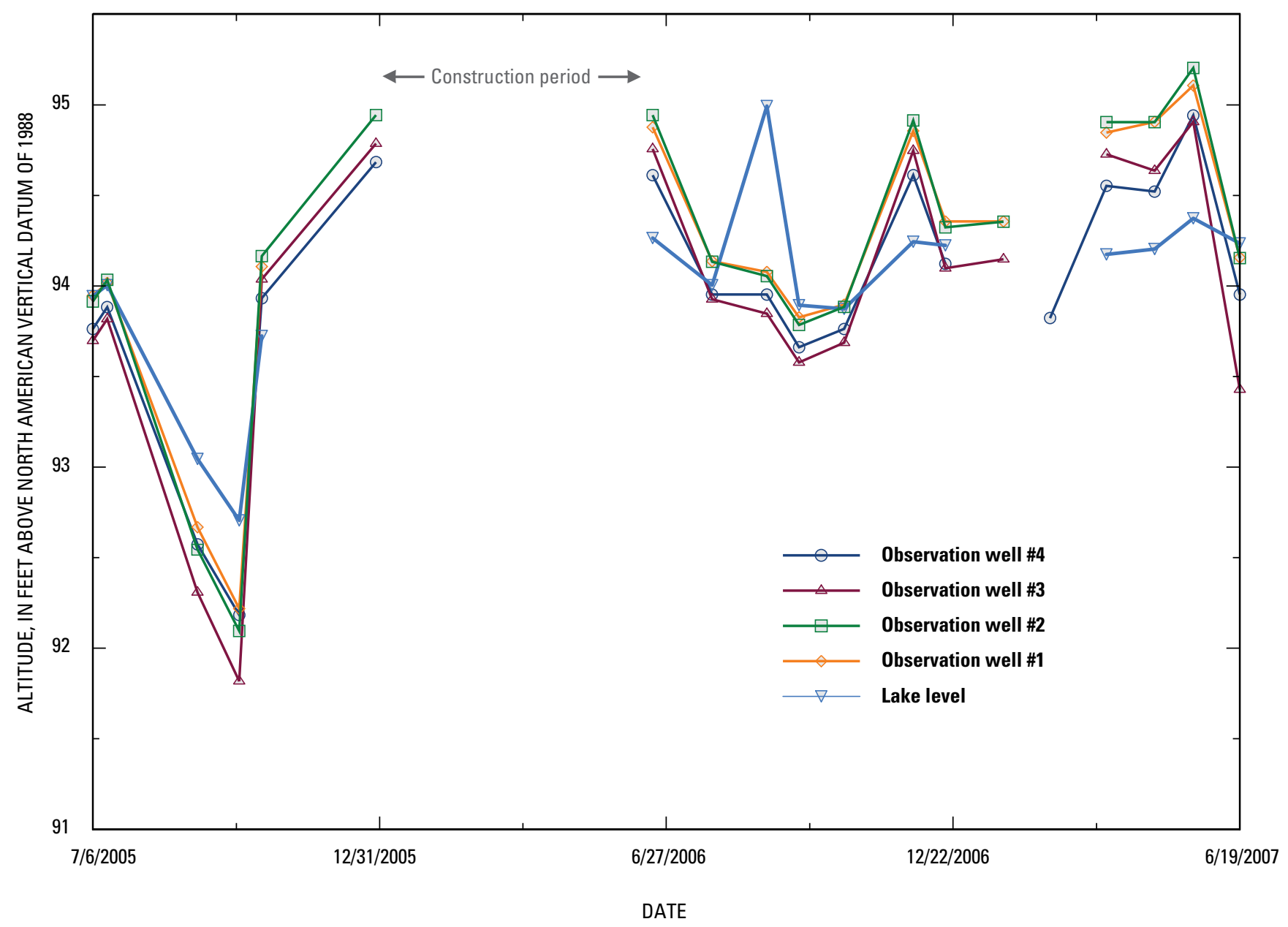

Figure 8. Altitudes of water table determined in multilevel samplers and of Silver Lake, Wilmington, MA, July 2005 to June 2007. 
Table 1. Concentrations of nutrients, dissolved metals, and total petroleum hydrocarbons in samples collected at water-table elevations from three multilevel samplers installed at the Silver Lake beach parking lot at Wilmington, MA, 2005-07.

[E, estimated value less than the reporting level; MLS, multilevel sampler; $<$, less than; shading indicates samples collected prior to installation of porous parking lot surface; L, sample lost during processing; --, not calculated]

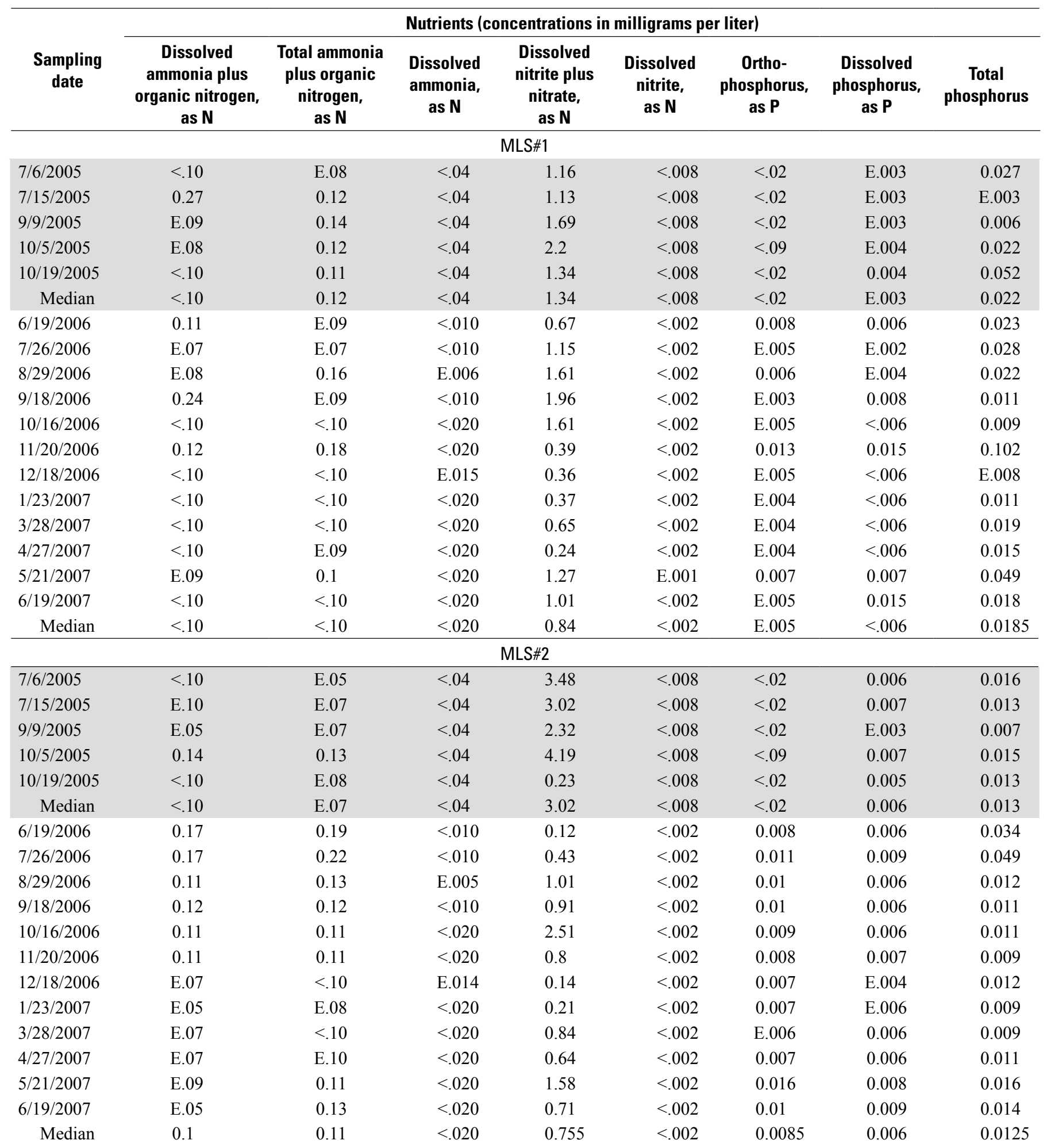


Table 1. Concentrations of nutrients, dissolved metals, and total petroleum hydrocarbons in samples collected at water-table elevations from three multilevel samplers installed at the Silver Lake beach parking lot at Wilmington, MA, 2005-07.-Continued

[E, estimated value less than the reporting level; MLS, multilevel sampler; $<$, less than; shading indicates samples collected prior to installation of porous parking lot surface; L, sample lost during processing; --, not calculated]

\begin{tabular}{|c|c|c|c|c|c|c|c|c|}
\hline \multirow[b]{2}{*}{$\begin{array}{l}\text { Sampling } \\
\text { date }\end{array}$} & \multicolumn{8}{|c|}{ Nutrients (concentrations in milligrams per liter) } \\
\hline & $\begin{array}{c}\text { Dissolved } \\
\text { ammonia plus } \\
\text { organic nitrogen, } \\
\text { as N }\end{array}$ & $\begin{array}{l}\text { Total ammonia } \\
\text { plus organic } \\
\text { nitrogen, } \\
\text { as } \mathbf{N}\end{array}$ & $\begin{array}{c}\text { Dissolved } \\
\text { ammonia, } \\
\text { as N }\end{array}$ & $\begin{array}{l}\text { Dissolved } \\
\text { nitrite plus } \\
\text { nitrate, } \\
\text { as N } \\
\end{array}$ & $\begin{array}{l}\text { Dissolved } \\
\text { nitrite, } \\
\text { as N }\end{array}$ & $\begin{array}{c}\text { Ortho- } \\
\text { phosphorus, } \\
\text { as P }\end{array}$ & $\begin{array}{c}\text { Dissolved } \\
\text { phosphorus, } \\
\text { as P }\end{array}$ & $\begin{array}{c}\text { Total } \\
\text { phosphorus }\end{array}$ \\
\hline \multicolumn{9}{|c|}{ MLS\#3 } \\
\hline $7 / 6 / 2005$ & $<.10$ & E.06 & $<.04$ & $<.06$ & $<.008$ & $<.02$ & E.003 & 0.054 \\
\hline $7 / 15 / 2005$ & 0.23 & 0.21 & 0.04 & $<.06$ & $<.008$ & $<.02$ & E. 003 & 0.017 \\
\hline 9/9/2005 & 0.15 & 0.23 & $<.04$ & 1.28 & 0.028 & $<.02$ & E.004 & 0.043 \\
\hline $10 / 5 / 2005$ & $<.10$ & E.06 & $<.04$ & E.03 & $<.008$ & $<.09$ & $<.004$ & 0.011 \\
\hline $10 / 19 / 2005$ & E. 07 & 0.22 & $<.04$ & 0.09 & $<.008$ & $<.02$ & $<.004$ & 0.114 \\
\hline Median & $<.10$ & 0.21 & $<.04$ & $<.06$ & $<.008$ & $<.02$ & $<.004$ & 0.043 \\
\hline $6 / 19 / 2006$ & $<.10$ & $<.10$ & $<.010$ & 0.56 & $<.002$ & E.004 & $<.004$ & 0.007 \\
\hline $7 / 26 / 2006$ & $<.10$ & $<.10$ & $<.010$ & E.04 & $<.002$ & $<.006$ & $<.004$ & 0.005 \\
\hline $8 / 29 / 2006$ & $<.10$ & Е.07 & E.006 & $<.06$ & $<.002$ & E.004 & $<.004$ & E.003 \\
\hline $9 / 18 / 2006$ & $<.10$ & $<.10$ & $<.010$ & $<.06$ & $<.002$ & E.005 & $<.004$ & E.003 \\
\hline $10 / 16 / 2006$ & $<.10$ & $<.10$ & $<.020$ & $<.06$ & $<.002$ & E. 004 & $<.006$ & E.004 \\
\hline $11 / 20 / 2006$ & 0.17 & 0.18 & $<.020$ & $<.06$ & $<.002$ & E.004 & E.004 & 0.02 \\
\hline $12 / 18 / 2006$ & $<.10$ & $<.10$ & E.016 & $<.06$ & $<.002$ & E.004 & $<.006$ & 0.009 \\
\hline $1 / 23 / 2007$ & $<.10$ & $<.10$ & $<.020$ & $<.06$ & $<.002$ & E. 004 & $<.006$ & E.006 \\
\hline $3 / 28 / 2007$ & $<.10$ & $<.10$ & $<.020$ & $<.06$ & $<.002$ & E. 003 & $<.006$ & E.005 \\
\hline $4 / 27 / 2007$ & $<.10$ & $<.10$ & $<.020$ & E.03 & $<.002$ & E.003 & $<.006$ & E.004 \\
\hline $5 / 21 / 2007$ & E.07 & E. 08 & E.010 & 0.16 & $<.002$ & E.004 & $<.006$ & 0.049 \\
\hline 6/19/2007 & $<.10$ & $<.10$ & $<.020$ & $<.06$ & $<.002$ & E.004 & $<.006$ & $<.008$ \\
\hline Median & $<0.10$ & $<0.10$ & $<.020$ & $<.06$ & $<.002$ & E.004 & $<.006$ & 0.005 \\
\hline
\end{tabular}


Table 1. Concentrations of nutrients, dissolved metals, and total petroleum hydrocarbons in samples collected at water-table elevations from three multilevel samplers installed at the Silver Lake beach parking lot at Wilmington, MA, 2005-07.—Continued

[E, estimated value less than the reporting level; MLS, multilevel sampler; $<$, less than; shading indicates samples collected prior to installation of porous parking lot surface; L, sample lost during processing; --, not calculated]

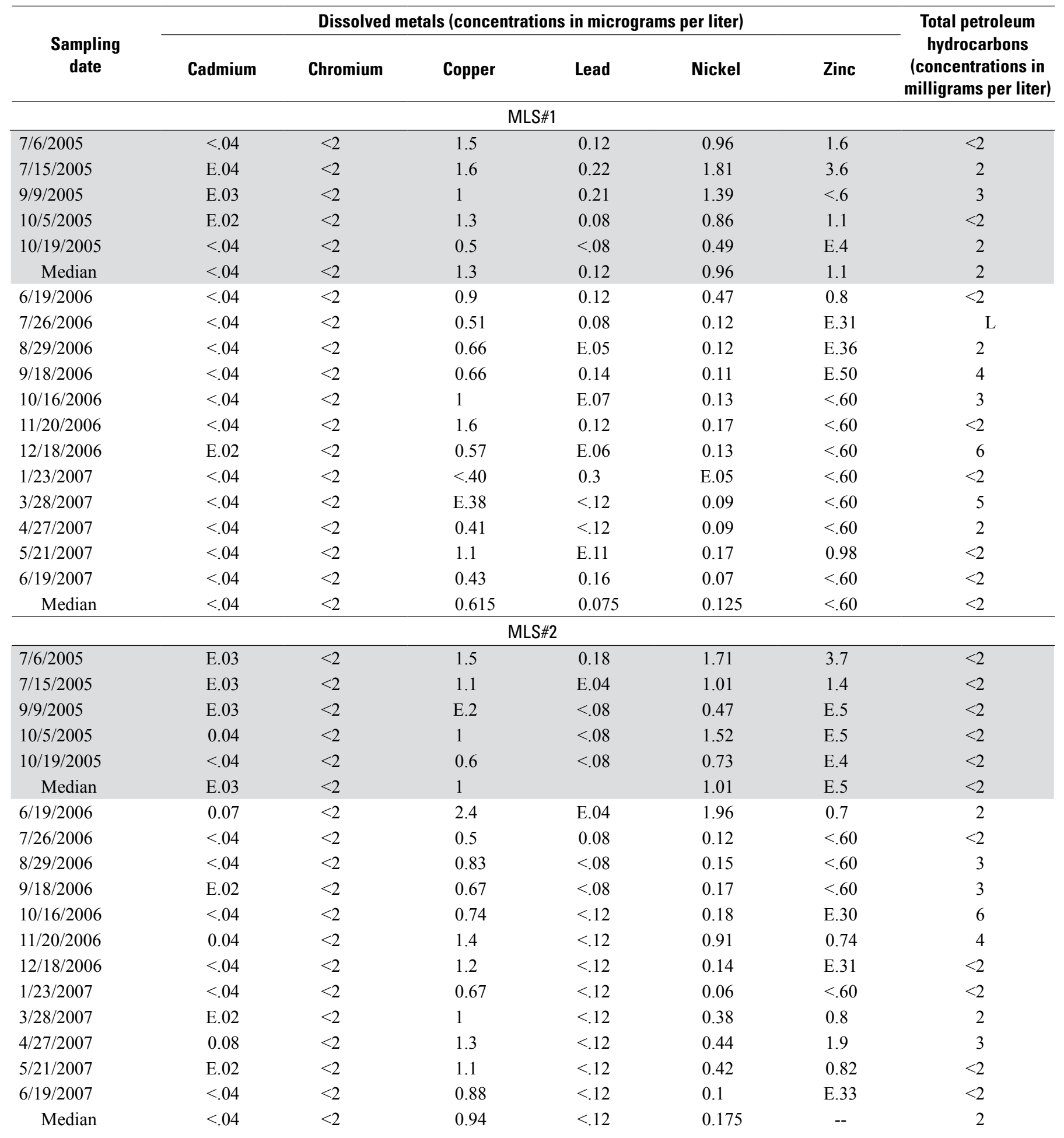


Table 1. Concentrations of nutrients, dissolved metals, and total petroleum hydrocarbons in samples collected at water-table elevations from three multilevel samplers installed at the Silver Lake beach parking lot at Wilmington, MA, 2005-07.—Continued

[E, estimated value less than the reporting level; MLS, multilevel sampler; <, less than; shading indicates samples collected prior to installation of porous parking lot surface; L, sample lost during processing; --, not calculated]

\begin{tabular}{|c|c|c|c|c|c|c|c|}
\hline \multirow{2}{*}{$\begin{array}{l}\text { Sampling } \\
\text { date }\end{array}$} & \multicolumn{6}{|c|}{ Dissolved metals (concentrations in micrograms per liter) } & \multirow{2}{*}{$\begin{array}{c}\text { Total petroleum } \\
\text { hydrocarbons } \\
\text { (concentrations in } \\
\text { milligrams per liter) }\end{array}$} \\
\hline & Cadmium & Chromium & Copper & Lead & Nickel & Zinc & \\
\hline \multicolumn{8}{|c|}{ MLS\#3 } \\
\hline 7/6/2005 & 0.16 & $<2$ & 0.9 & 0.11 & 2.89 & 66.3 & $<2$ \\
\hline $7 / 15 / 2005$ & 0.16 & E1 & 4.8 & 0.81 & 2.72 & 8.5 & $<2$ \\
\hline 9/9/2005 & 0.16 & E2 & 3.6 & 0.63 & 2.33 & 4.2 & $<2$ \\
\hline $10 / 5 / 2005$ & 0.44 & $<2$ & 1.4 & 0.13 & 8.94 & 157 & $<2$ \\
\hline $10 / 19 / 2005$ & 0.12 & $<2$ & 1.9 & 0.18 & 3.45 & 77.4 & 2 \\
\hline Median & 0.16 & & 1.9 & 0.18 & 2.89 & 66.3 & $<2$ \\
\hline $6 / 19 / 2006$ & 0.32 & $<2$ & 0.9 & E.07 & 1.2 & 143 & 3 \\
\hline $7 / 26 / 2006$ & 0.31 & $<2$ & 0.83 & 0.11 & 1.1 & 102 & $<2$ \\
\hline $8 / 29 / 2006$ & 0.2 & $<2$ & 0.61 & E.05 & 0.71 & 90.4 & $<2$ \\
\hline $9 / 18 / 2006$ & 0.28 & $<2$ & 0.63 & E.06 & 0.84 & 108 & $<2$ \\
\hline $10 / 16 / 2006$ & 0.42 & $<2$ & 0.8 & E.11 & 1.1 & 143 & 2 \\
\hline $11 / 20 / 2006$ & 0.13 & $<2$ & 4.9 & 0.6 & 1.7 & 16.6 & 3 \\
\hline $12 / 18 / 2006$ & 0.36 & $<2$ & 0.92 & E.11 & 1.2 & 120 & 3 \\
\hline $1 / 23 / 2007$ & 0.33 & $<2$ & 0.63 & E.09 & 0.76 & 123 & $<2$ \\
\hline $3 / 28 / 2007$ & 0.32 & $<2$ & 0.81 & E.08 & 0.87 & 138 & 6 \\
\hline $4 / 27 / 2007$ & 0.26 & $<2$ & 0.79 & E.09 & 0.74 & 119 & $<2$ \\
\hline $5 / 21 / 2007$ & 0.11 & $<2$ & 1.9 & 0.34 & 0.86 & 16 & $\mathrm{~L}$ \\
\hline $6 / 19 / 2007$ & 0.48 & $<2$ & 0.76 & 0.18 & 1.1 & 206 & 6 \\
\hline Median & 0.31 & $<2$ & 0.805 & 0.1 & 0.985 & 120.5 & 2 \\
\hline
\end{tabular}


Table 2. Concentrations of nutrients, dissolved and total metals, and total petroleum hydrocarbons in quality-control and corresponding environmental samples collected at the Silver Lake beach parking lot and the Silver Lake Avenue runoff site in Wilmington, MA, and Whipple Annex and Town Hall roof-runoff sites in Ipswich, MA, 2005-07.

[Samples from Silver Lake beach parking lot were alalyzed for dissolved metals; samples from Lake Avenue runoff and roof runoff were analyzed for total metals. E, estimated value less than the reporting level; <, less than; shading indicates samples collected prior to installation of porous parking lot surface; total petroleum hydrocarbons values of detections in bold print, do not have unacceptably high laboratory blank contamination; L, sample lost during processing; M, detected, but not quantifiable; --, missing or not calculated; ns, sample not collected; ENV, environmental sample; REP, replicate sample; SOIL, green roof planting medium slurry sample; BLK, blank sample; RPD, relative percent difference; MLS, multilevel sampler; BP, bulk precipitation sample; TH, Town Hall; GR, Whipple Annex green roof; GS, USGS clean room]

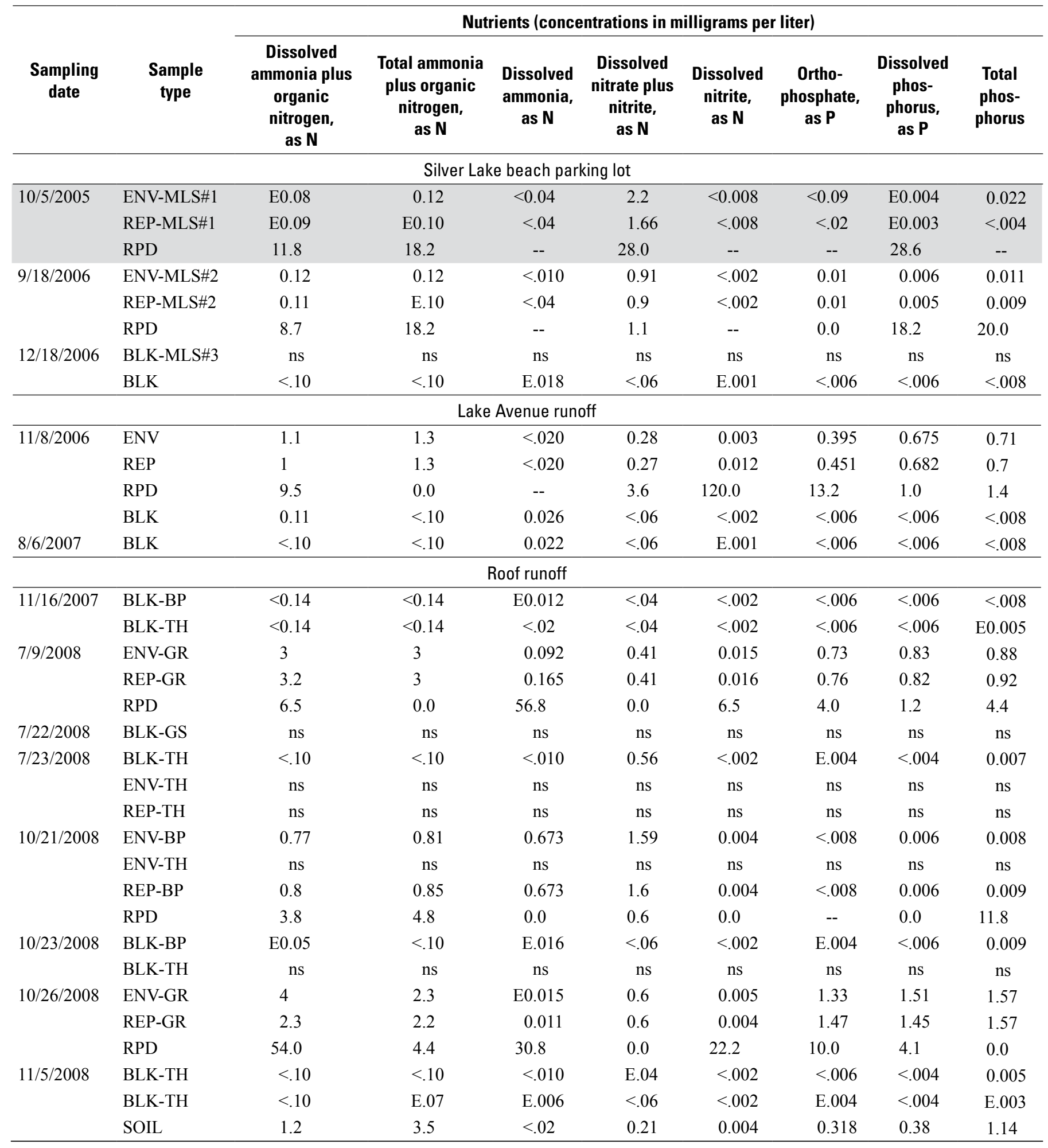


Table 2. Concentrations of nutrients, dissolved and total metals, and total petroleum hydrocarbons in quality-control and corresponding environmental samples collected at the Silver Lake beach parking lot and the Silver Lake Avenue runoff site in Wilmington, MA, and Whipple Annex and Town Hall roof-runoff sites in Ipswich, MA, 2005-07.-Continued

[Samples from Silver Lake beach parking lot were alalyzed for dissolved metals; samples from Lake Avenue runoff and roof runoff were analyzed for total metals. E, estimated value less than the reporting level; <, less than; shading indicates samples collected prior to installation of porous parking lot surface; total petroleum hydrocarbons values of detections in bold print, do not have unacceptably high laboratory blank contamination; L, sample lost during processing; M, detected, but not quantifiable; --, missing or not calculated; ns, sample not collected; ENV, environmental sample; REP, replicate sample; SOIL, green roof planting medium slurry sample; BLK, blank sample; RPD, relative percent difference; MLS, multilevel sampler; BP, bulk precipitation sample; TH, Town Hall; GR, Whipple Annex green roof; GS, USGS clean room]

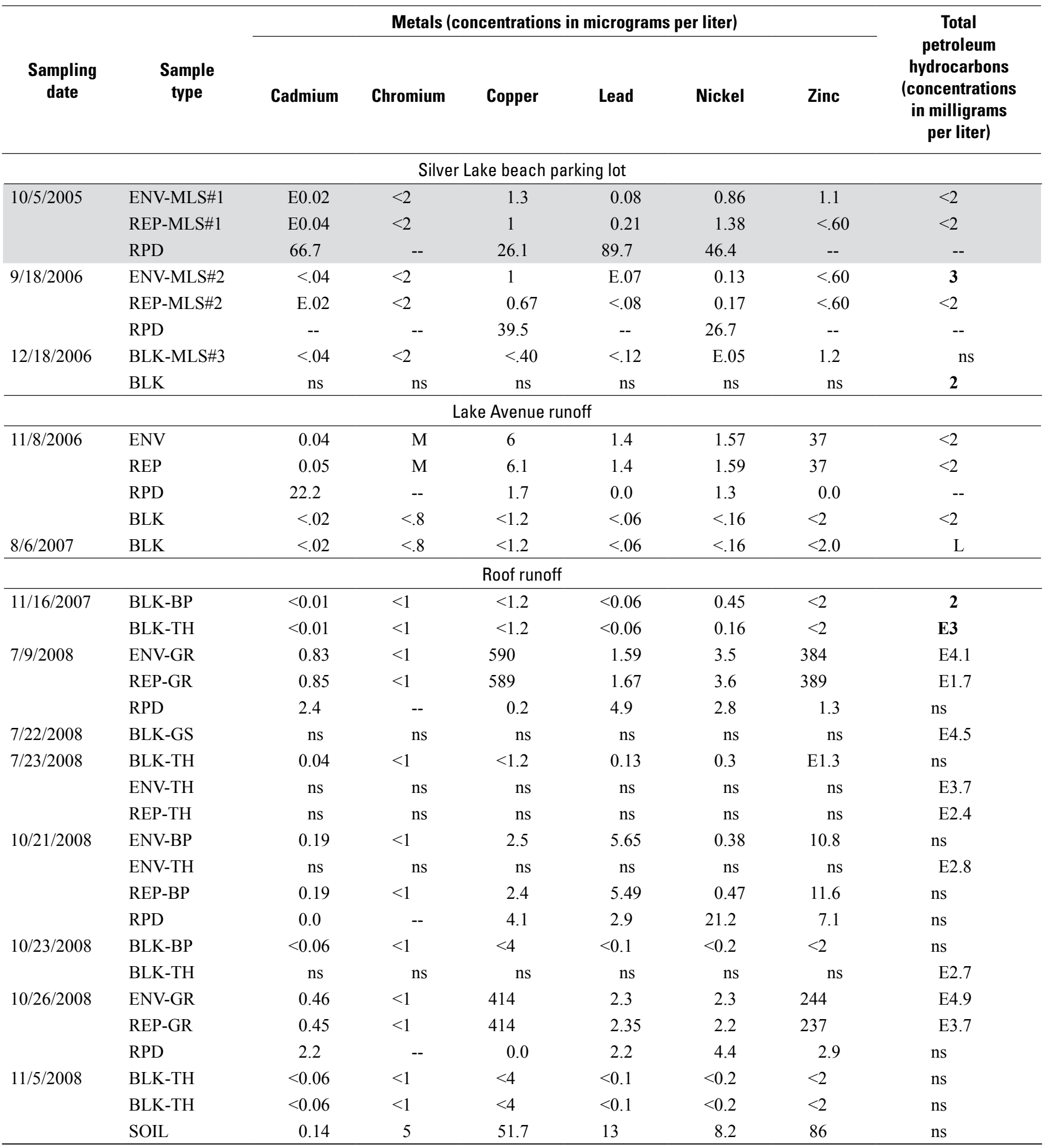




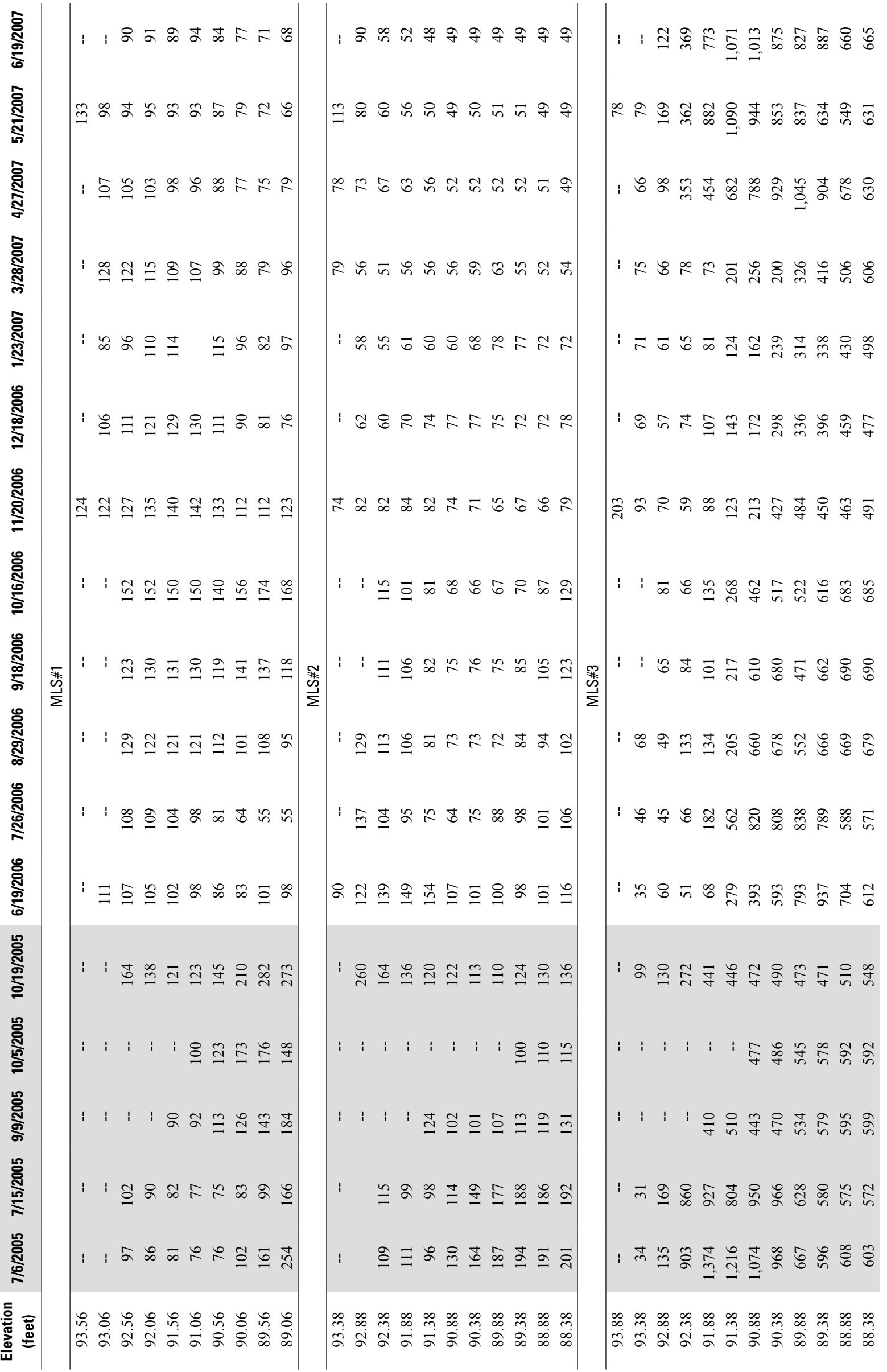


Field Studies of Low-Impact-Development Techniques

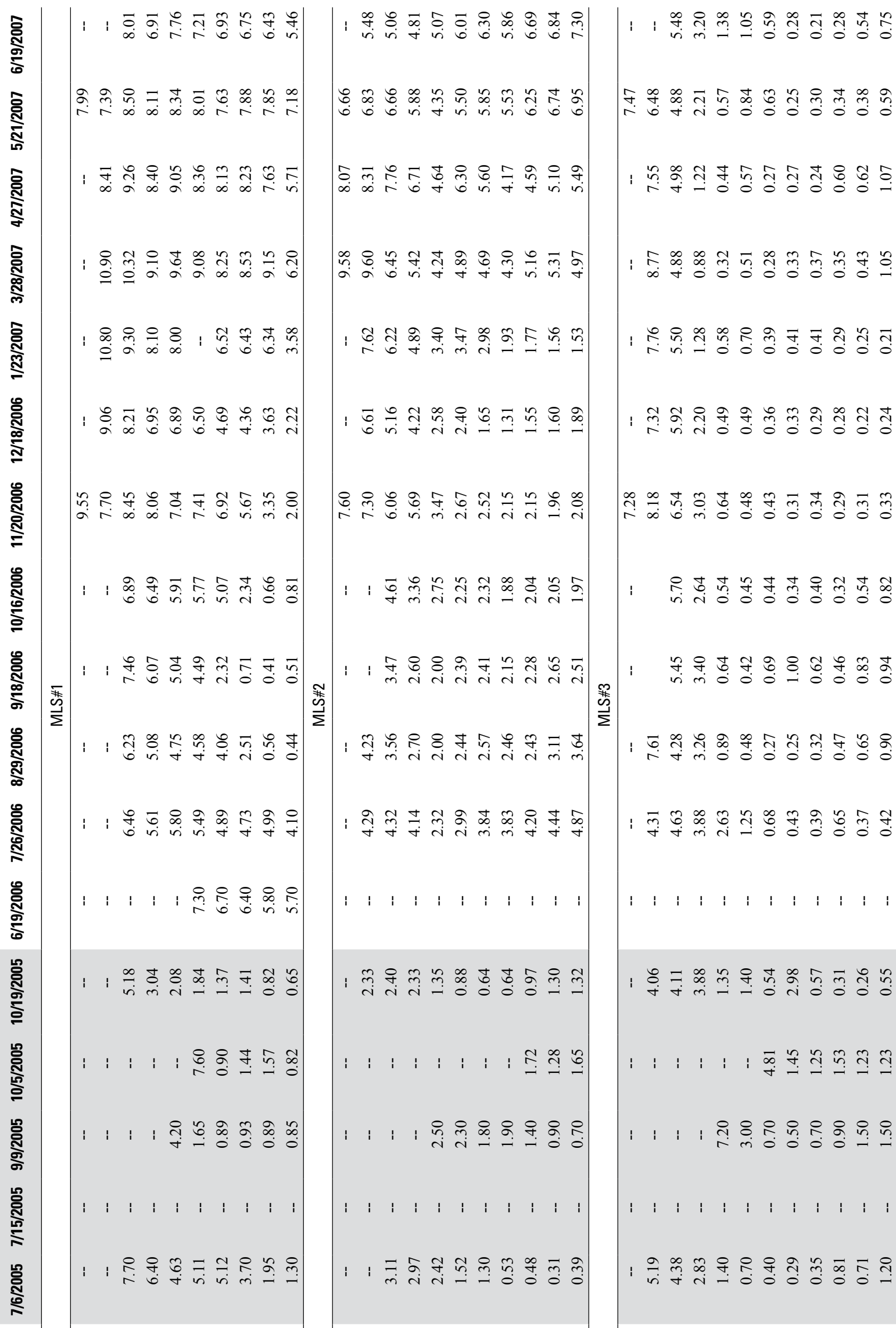

요 8 i 8

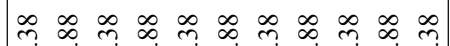

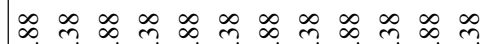

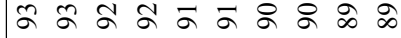

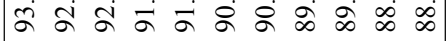
๙ं 


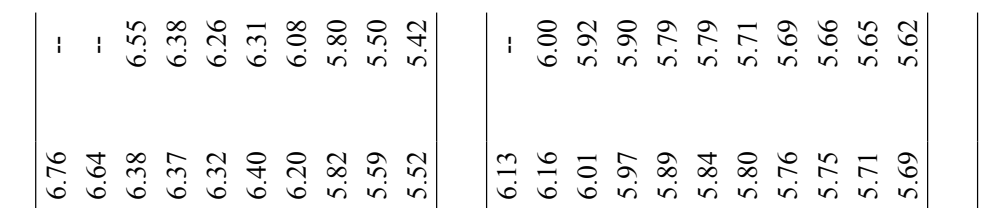

: 季 $\begin{aligned} & q \\ & 0\end{aligned}$ (1)

1 (n)

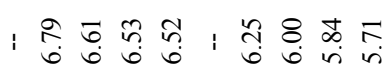

भु.

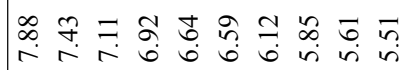

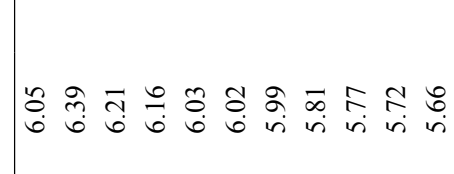

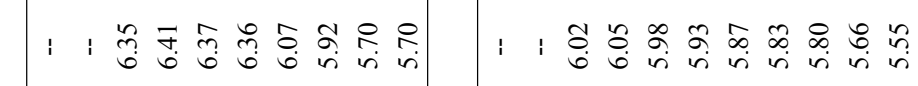

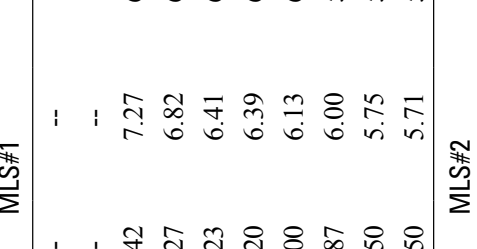

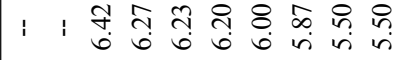

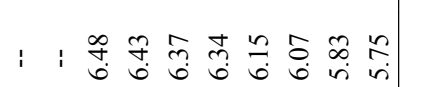

(a)

:

(n)

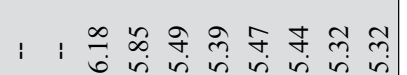

1

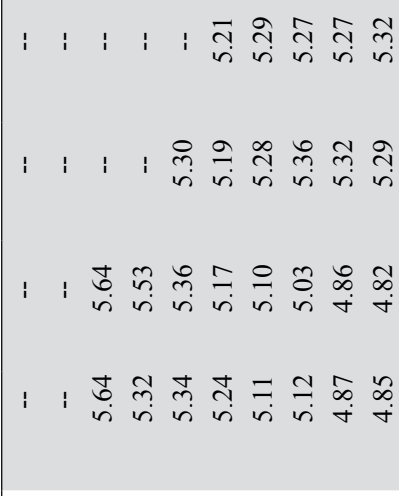

뉴 8 \%

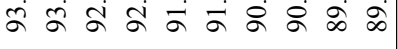

กิ่

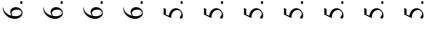

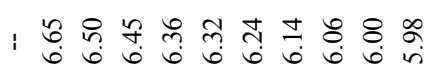

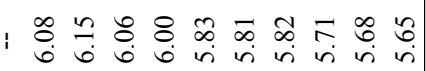

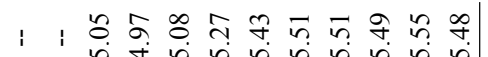

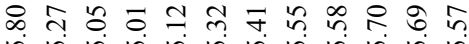

के तु

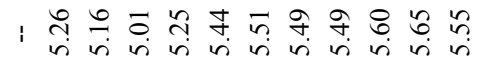

|

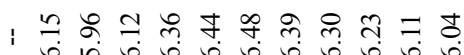

: ते

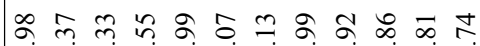

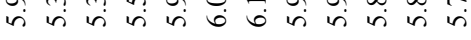

: $\quad$ !

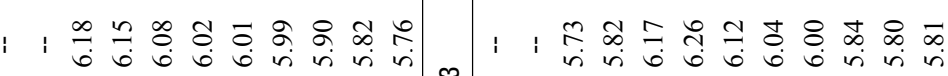
$\stackrel{\text { 零 }}{\Sigma}$

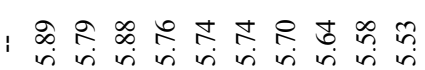

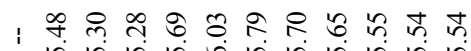

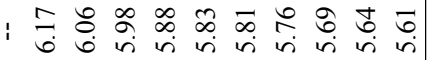

1 ते ते

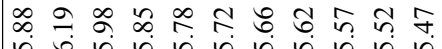

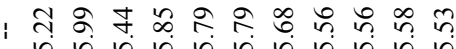
in 6 in in is is in in in की

두

:

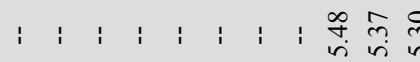

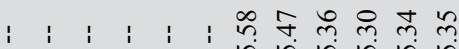

$1 \quad 1 \quad$ in

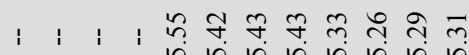

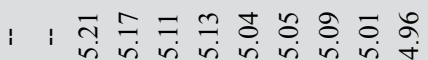

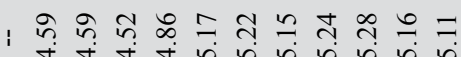

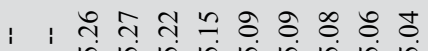

:

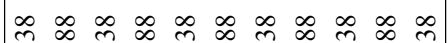

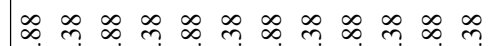
๙ুสু 
the highest values were found in samples from the deepest port from which water could be drawn. In MLS\#2, the single highest value was found in samples from the highest port yielding water (October 19, 2005), although, in July 2005, the deepest ports had the highest specific conductance values. A comparison of the mean and range of specific conductance profiles for MLS\#1 indicates no substantial changes in data from the uppermost sampling ports after the porous parking lot was installed (fig. 9); the specific conductance values for the lowest ports seem to have declined, leaving median values that change little from the top to bottom ports after installation. The pre- to post-installation changes likely reflect differences between the relatively dry summer and autumn of 2005 and the wetter autumn of 2006. There may also be an effect from the direct infiltration of rain water after installation. Specific conductance data for MLS\#3 (table 3) are higher than for MLS\#1 or MSL\#2; most of the measurements for MLS\#3 are $200 \mu \mathrm{S} / \mathrm{cm}$ or more with a high of $1,374 \mu \mathrm{S} / \mathrm{cm}$.

Dissolved oxygen (DO) concentrations before and after installation of the porous parking lot also differ somewhat among the MLS wells (table 3). Median DO concentrations (fig. 10) in samples from all ports in MLS\#1 increased, which may be a response to surficial disruption and increased aeration caused by the removal of the impervious asphalt; however, the range of values for MLS\#1 overlap substantially, except at deepest levels, indicating no substantial changes overall. For MLS\#2, the DO concentrations seem to have risen somewhat more between 2005 and 2006 than in MLS\#1. The median DO concentrations at MLS\#2 before installation ranged from 0.64 to $2.76 \mathrm{mg} / \mathrm{L}$ along the depth profile, and after installation concentrations ranged from 2.43 to $7.835 \mathrm{mg} / \mathrm{L}$ (data not shown). The DO concentrations for MLS\#3 have a wider range with many of the lowest ports yielding samples with less than $1 \mathrm{mg} / \mathrm{L}$ of DO in both years.

Values of $\mathrm{pH}$ seem to have risen slightly for all three wells (table 3 ) after installation of the porous parking lot. The profile data for MLS\#1 and MLS\#2 are similar to each other with highest to lowest $\mathrm{pH}$ values generally found in a gradient from the highest-elevation ports to the lowest. The $\mathrm{pH}$ values in MLS\#3 do not follow such a pattern; the lowest $\mathrm{pH}$ values are generally associated with the highest-elevation ports.

Although some of the differences in field characteristic values may be due to the effects of recharge after replacing the parking lot surface, the hydrology of a relatively dry year (2005) versus that of a wetter one (2006) probably contributed to these values too. The differences in field characteristics between MLS\#3 and the two downgradient wells, MLS\#1 and MLS\#2, seem to indicate that MLS\#1 and MLS\#2, which were present before installation of the parking lot, may not actually be downgradient from MLS\#3; in other words, groundwater flow from MLS\#3 probably bypasses the two parking lot MLS sampling sites. Thus, differences in other chemical characteristics between MLS\#3 and the two downgradient MLSs are unlikely to reflect changes that resulted from parking lot installation.

\section{Nutrients, Dissolved Metals, and Total Petroleum Hydrocarbons}

Differences in concentrations of all analytes also were examined in relation to month-to-month water levels; no consistent trends were determined (figs. 11 to 19). For MLS\#1, the highest concentrations of several of the nutrient analytes and dissolved copper were detected on November 20, 2006, the date when the water table was closest to the land surface; however, this value is not part of a trend. Because of the inferences and observations cited in the previous paragraph, figures depicting the concentrations of water-quality constituents (figs. 11 to 19) are limited to data for MLS\#1; data for MLS\#2 and MLS\#3 are listed in table 1. Because estimated values less than the reporting level appear in the data tables, the detection limit, generally, one-half the value of the reporting level, is indicated on the figures, where appropriate.

\section{Nutrients}

Differences in concentrations of analytes of nitrogen and phosphorus in MLS\#1 (figs. 11 to 14) and MLS\#2 before and after installation of the porous parking lot (table 1) are not statistically significant $(\alpha=0.05)$ when the Wilcoxon ranksum test is applied. However, more variability in concentrations is apparent after installation, probably resulting from the increase in the range of concentrations when more samples were collected after replacement of the old parking lot rather than resulting from the effects of the installation of the new parking lot surface.

For MLS\#3, in spite of the low number of samples collected, there is a statistically significant decrease in total phosphorus concentrations after the parking lot installation. Nitrogen analytes and dissolved phosphorus were not detected in a sufficient number of samples from MLS\#3 to enable statistical analysis (table 1). Orthophosphorus was not detected in any of the wells during the pre-installation period; the reporting level for orthophosphorus was lowered after that period, and orthophosphorus was detected in the wells after the porous parking lot was installed. Orthophosphorus concentrations in MLS\#3 never exceeded the pre-installation reporting level or detection limit.

\section{Dissolved Metals}

As with some of the nutrient analytes, some of the dissolved metals were rarely detected in particular wells, rendering graphical statistical analyses, such as boxplot comparisons, not especially helpful: chromium was only detected twice (in MLS\#3); cadmium was rarely detected in MLS\#1 and frequently not detected in MLS\#2; lead was detected only four times in MLS\#2; and zinc was frequently not found in MLS\#1. Bar charts depicting concentrations of the most commonly detected analytes, $\mathrm{Cu}, \mathrm{Pb}, \mathrm{Ni}$, and $\mathrm{Zn}$ in MLS\#1 are presented (figs. 15 to 18). In general, MLS\#3 had the highest frequency of metal detections (table 1). Of the three MLSs, MLS\#3 is closest to the bordering road, and its groundwater 


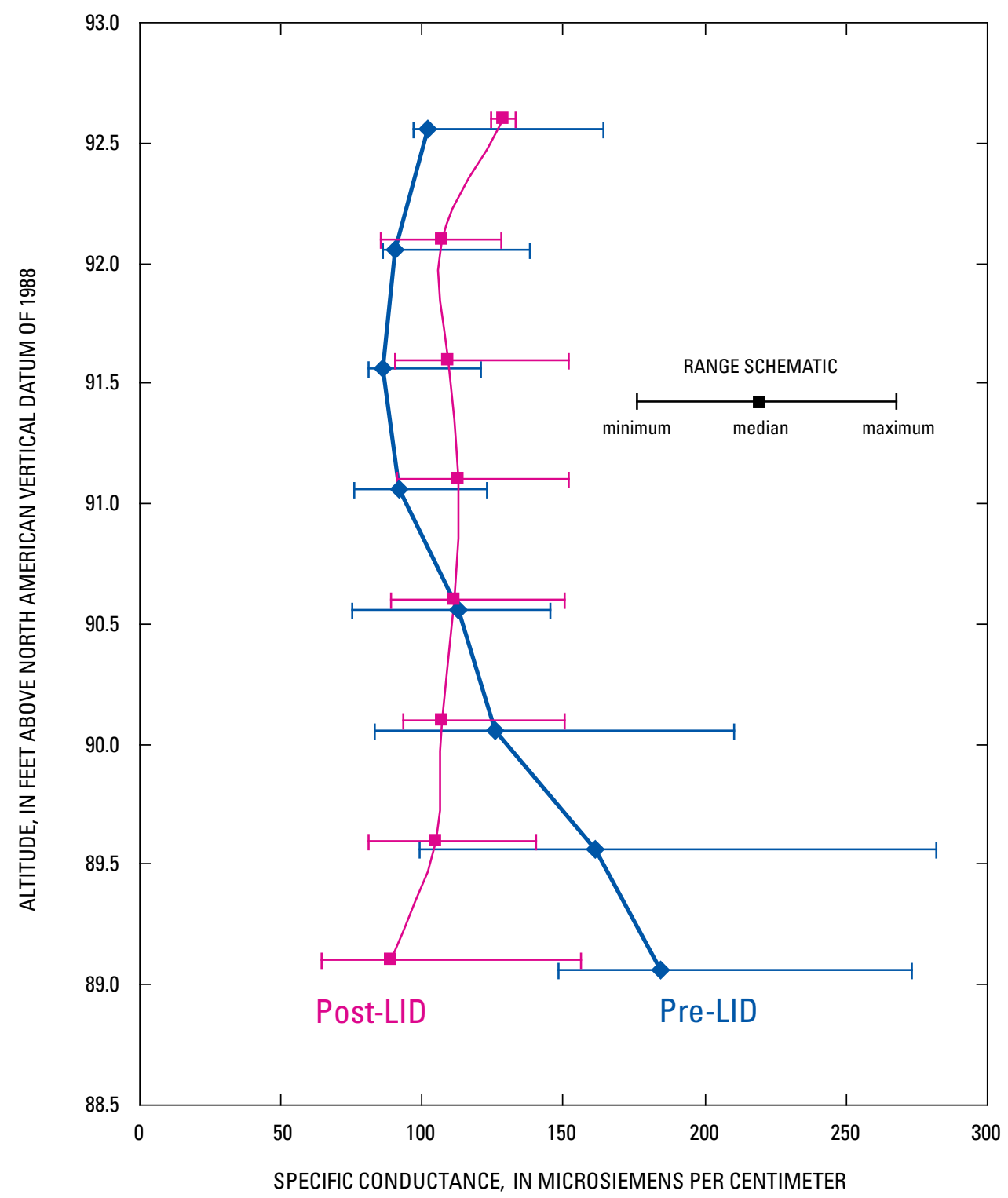

Figure 9. Minimum, median, and maximum specific conductance values in groundwater samples collected at multilevel-sampler well number 1 (MLS\#1) before (pre-low-impact development) and after (post-low-impact-development) installation of a porous parking lot at Silver Lake Beach, Wilmington, MA. The profiles are slightly offset to facilitate comparison. Pre-LID, pre-low-impact development; Post-LID, post-low-impact development. 


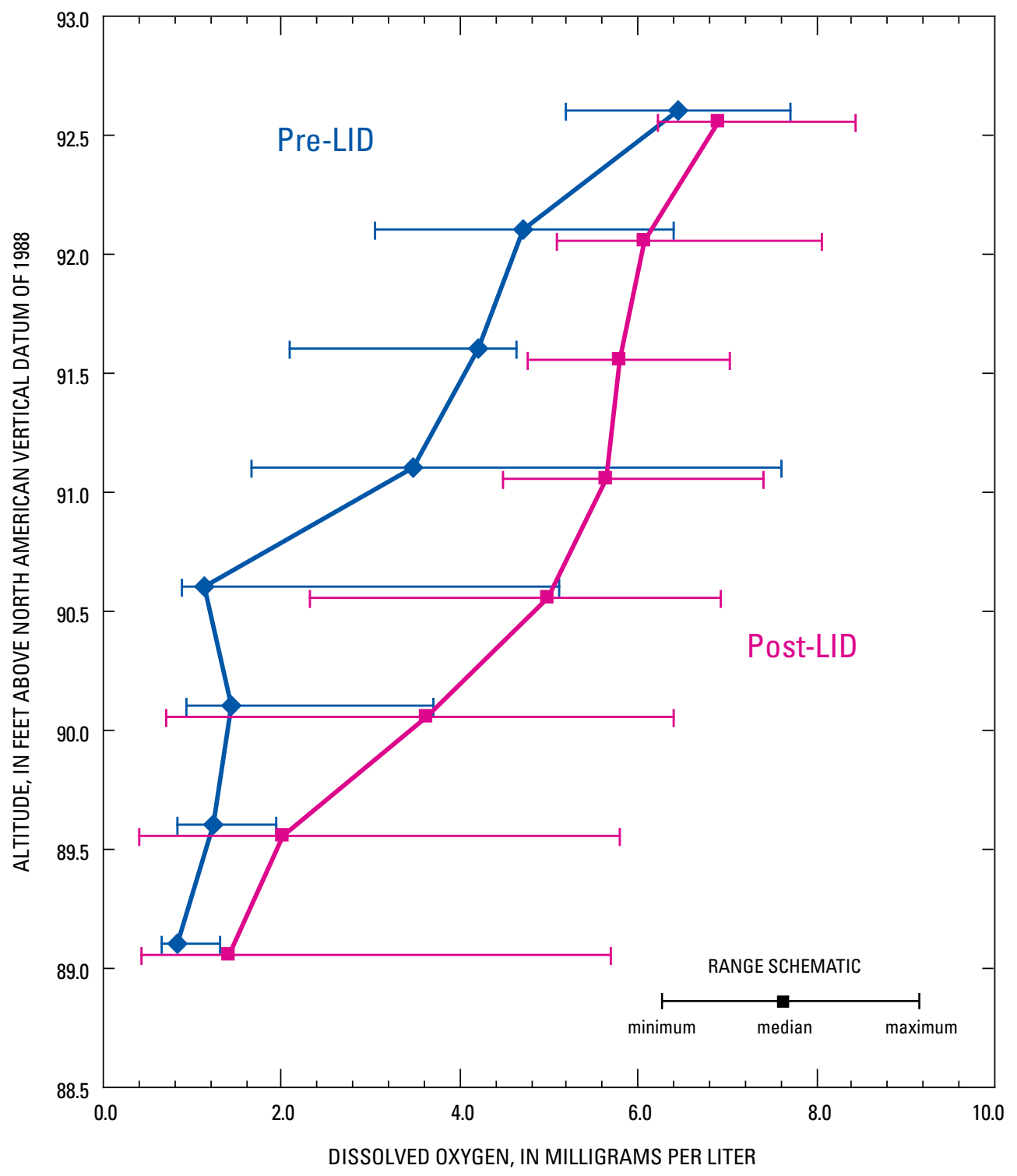

Figure 10. Minimum, median, and maximum dissolved oxygen concentrations in groundwater samples collected at multilevel-sampler well number 1 (MLS\#1) before (pre-low-impact development) and after (post-low-impact-development) installation of a porous parking lot at Silver Lake Beach, Wilmington, MA. The profiles are slightly offset to facilitate comparison. Pre-LID, pre-low-impact development; Post-LID, post-low-impact development. 


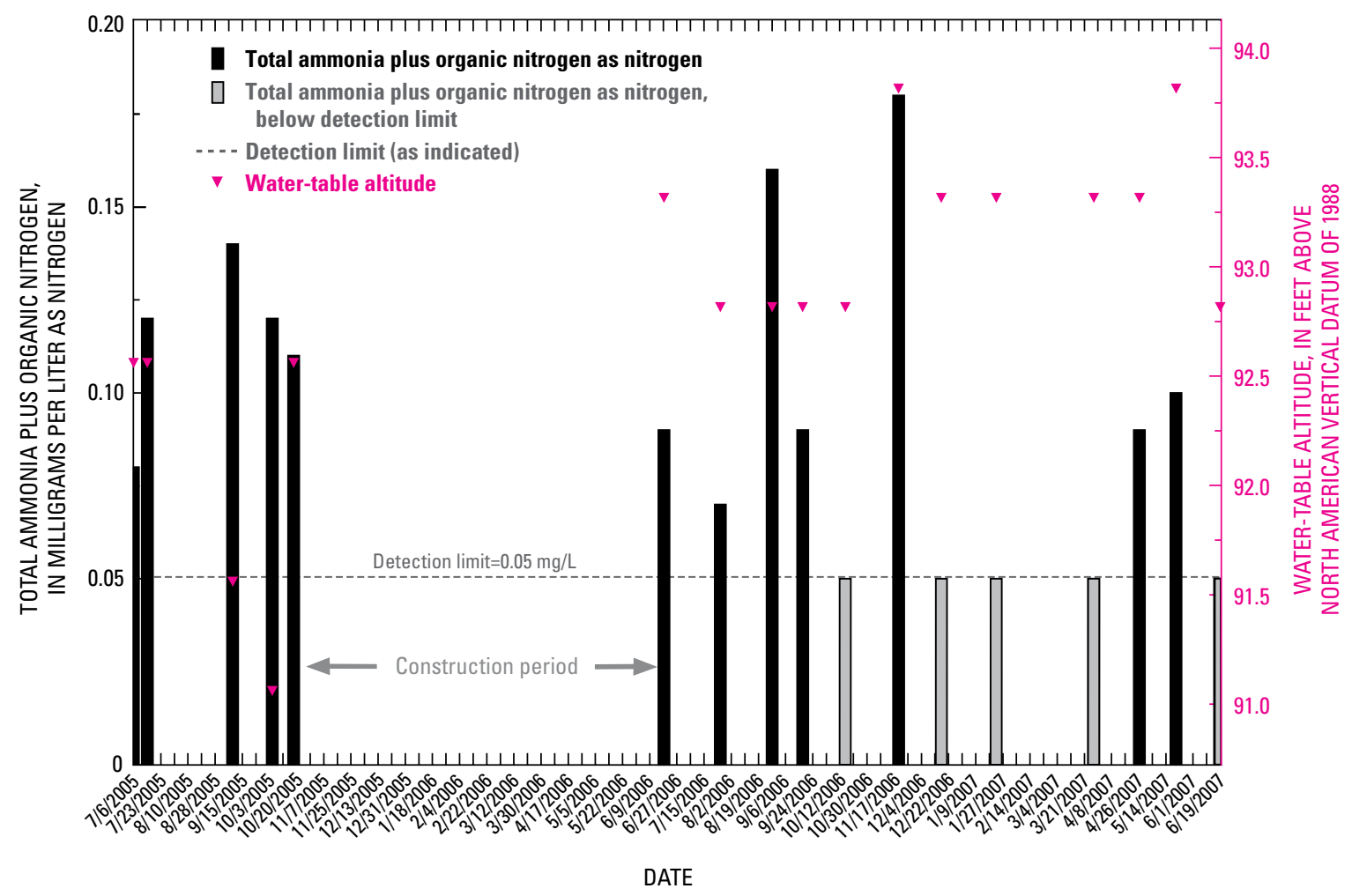

Figure 11. Total ammonia plus organic nitrogen concentrations and water-table altitudes in multilevel-sampler well number 1 (MLS\#1) before and after installation of a porous parking lot at Silver Lake Beach, Wilmington, MA. Empty bar indicates nondetect.

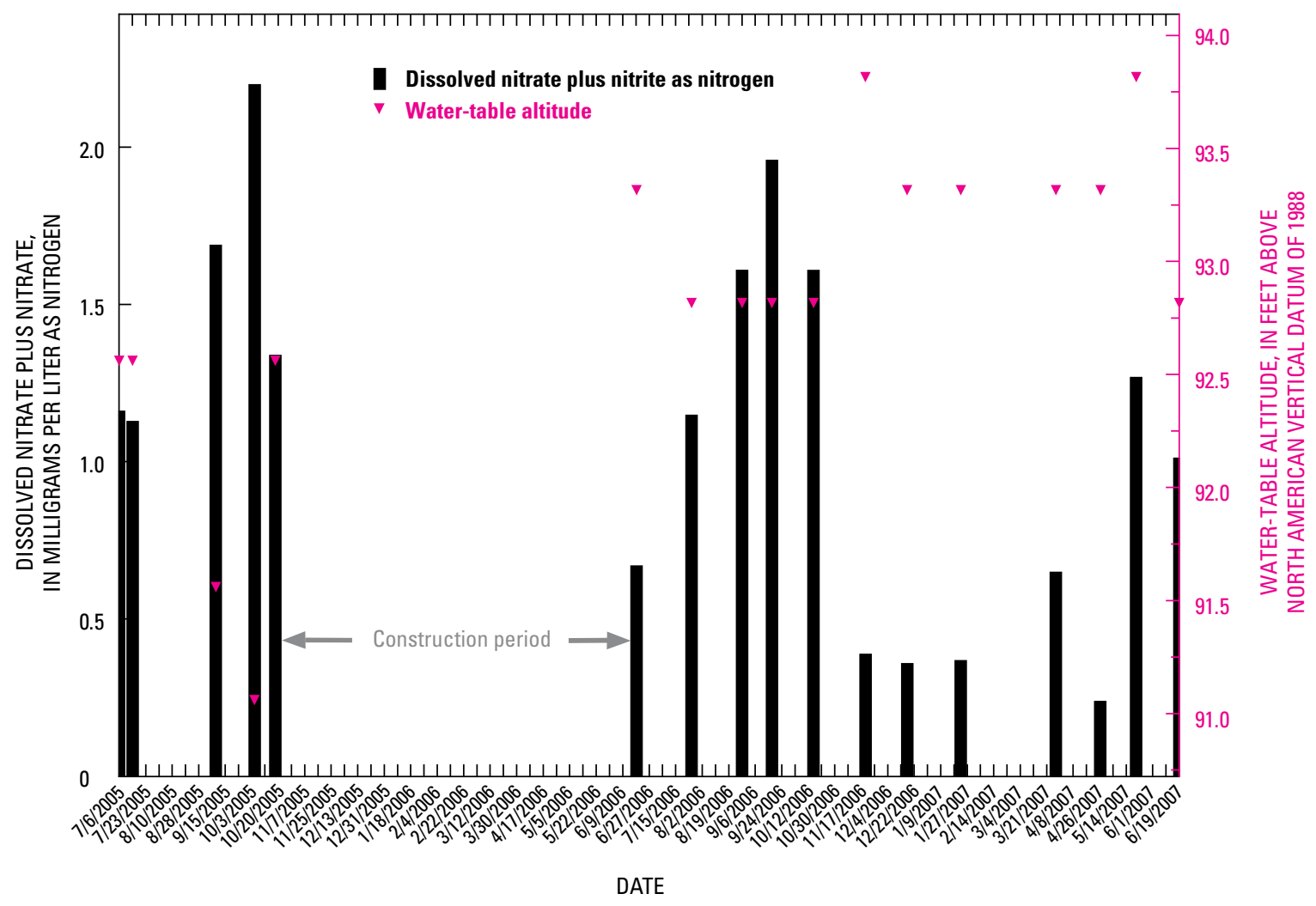

Figure 12. Dissolved nitrate plus nitrite nitrogen concentrations and water-table altitudes in multilevel-sampler well number 1 (MLS\#1) before and after installation of a porous parking lot at Silver Lake Beach, Wilmington, MA. 


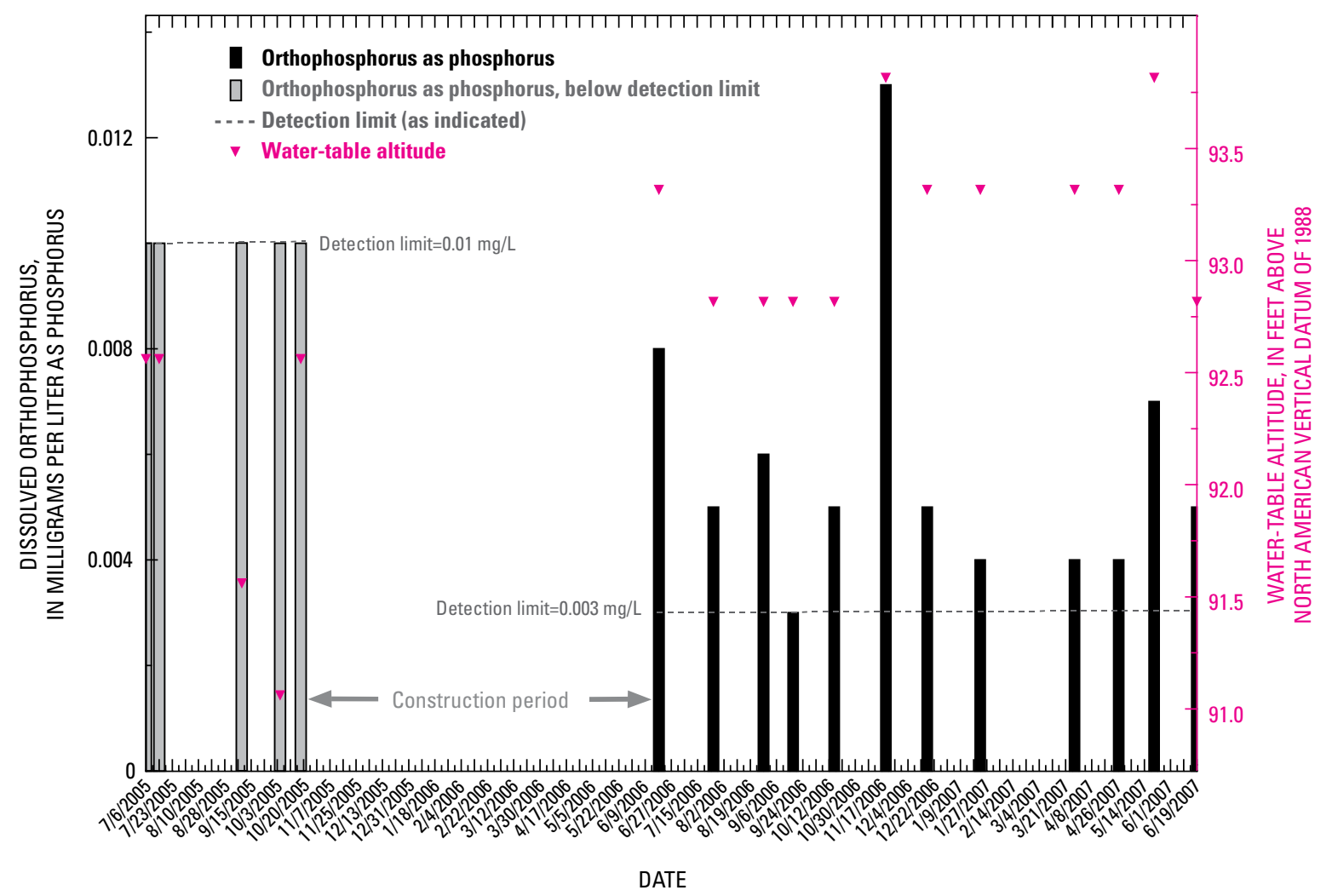

Figure 13. Dissolved orthophosphorus concentrations and water-table altitudes in multilevel-sampler well number 1 (MLS\#1) before and after installation of a porous parking lot at Silver Lake Beach, Wilmington, MA.

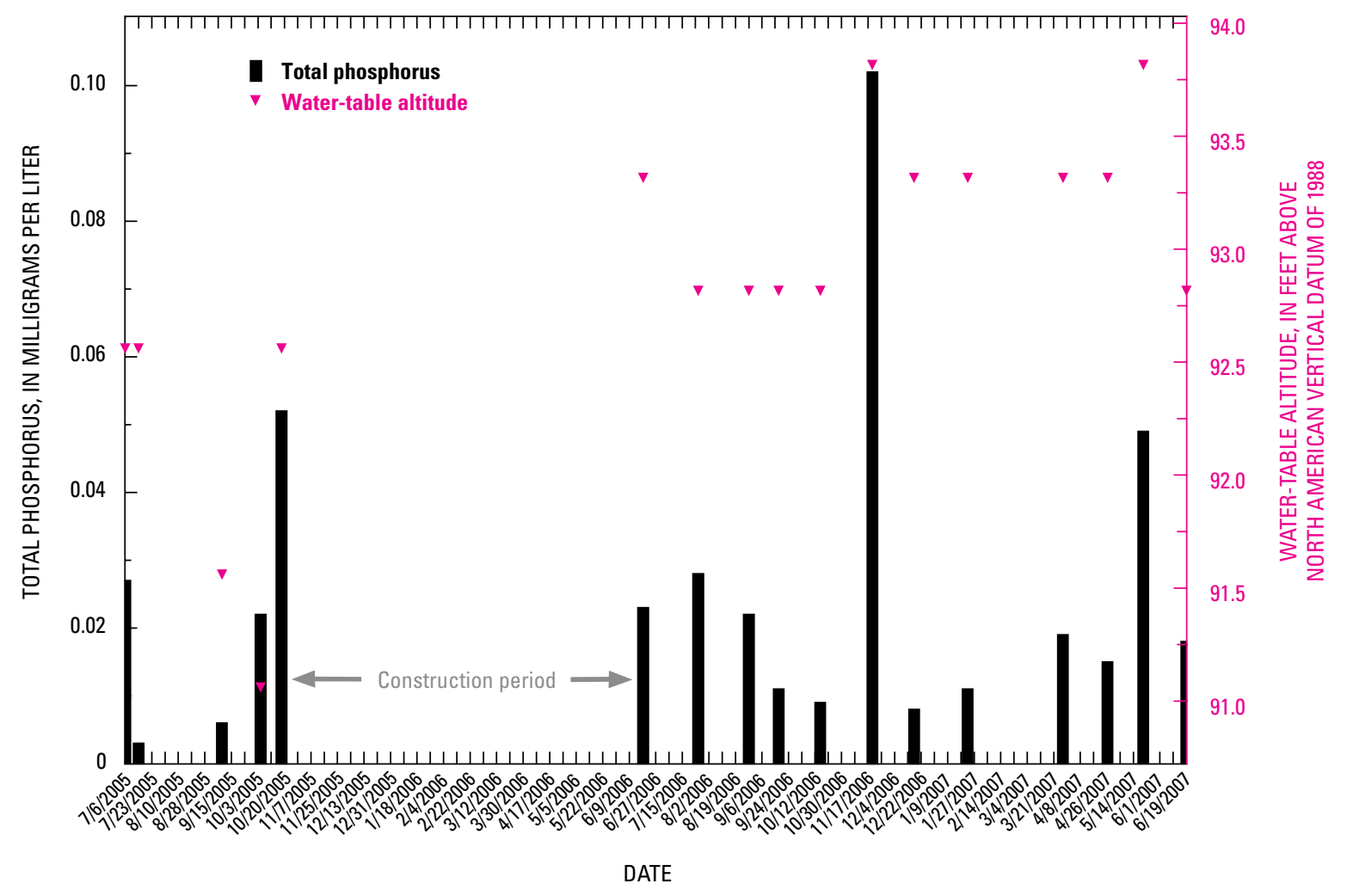

Figure 14. Total phosphorus concentrations and water-table altitudes in multilevel-sampler well number 1 (MLS\#1) before and after installation of a porous parking lot at Silver Lake Beach, Wilmington, MA. 


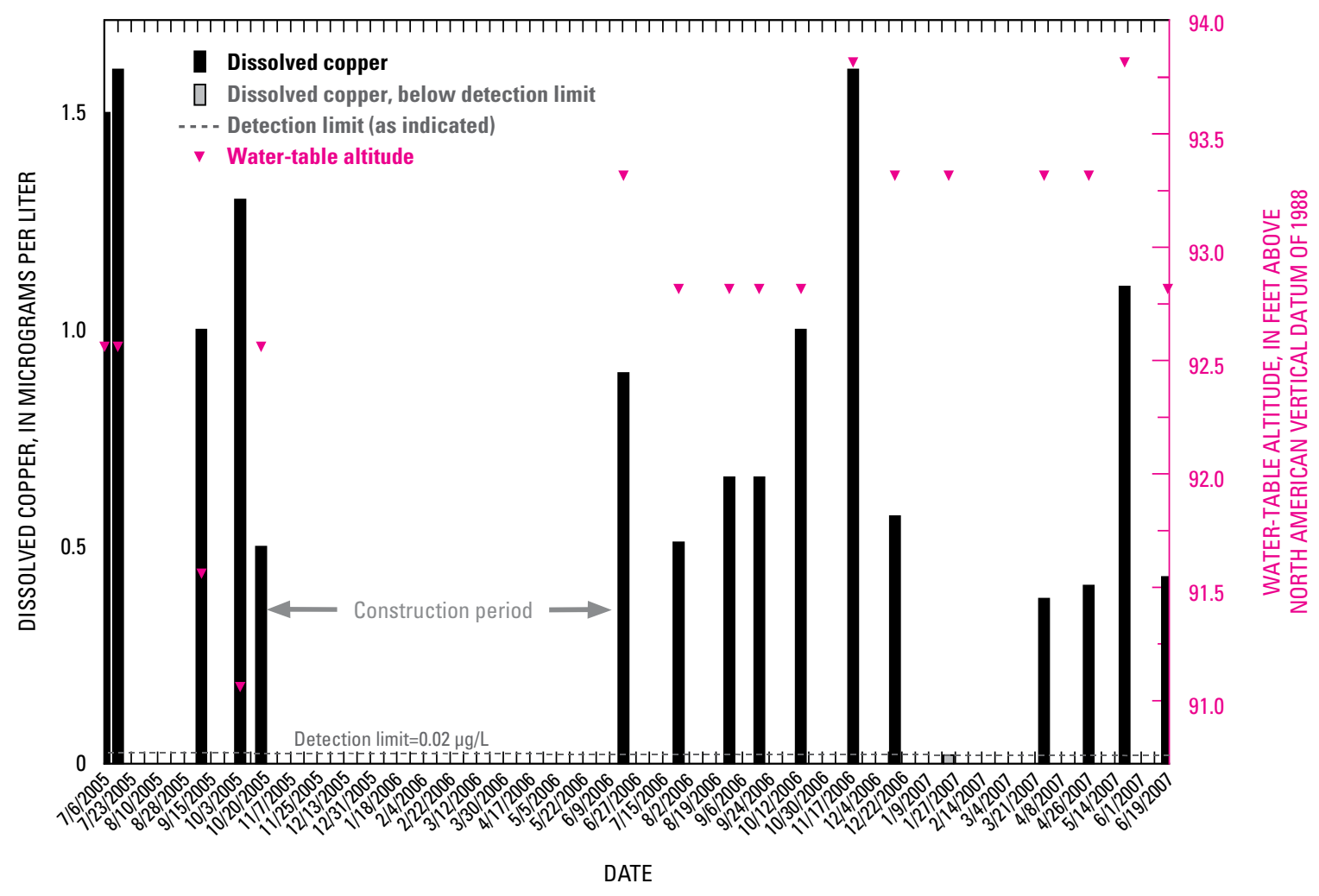

Figure 15. Dissolved copper concentrations and water-table altitudes in multilevel-sampler well number 1 (MLS\#1) before and after installation of a porous parking lot at Silver Lake Beach, Wilmington, MA.

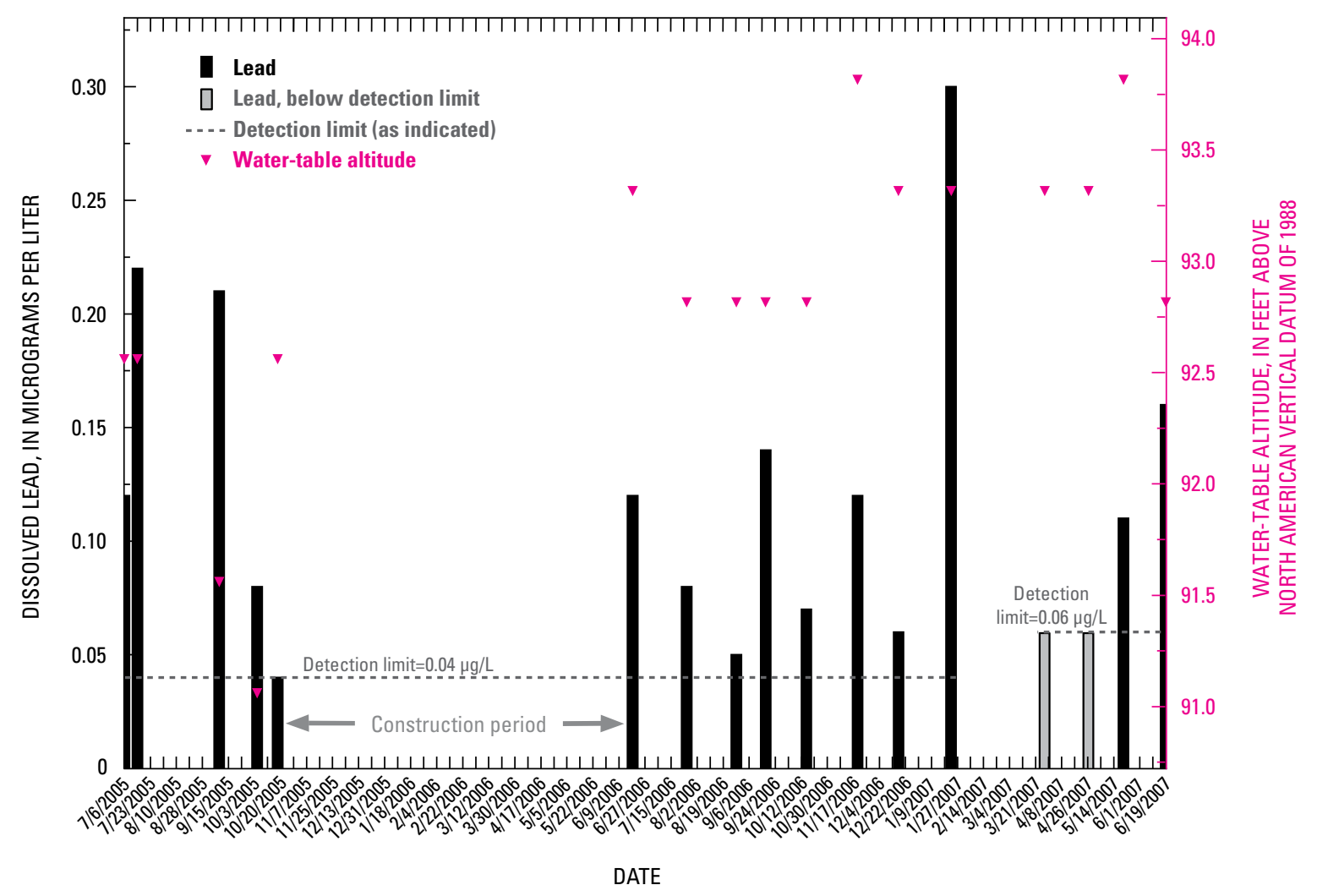

Figure 16. Dissolved lead concentrations and water-table altitudes in multilevel-sampler well number 1 (MLS\#1) before and after installation of a porous parking lot at Silver Lake Beach, Wilmington, MA. Empty bar indicates nondetect. 


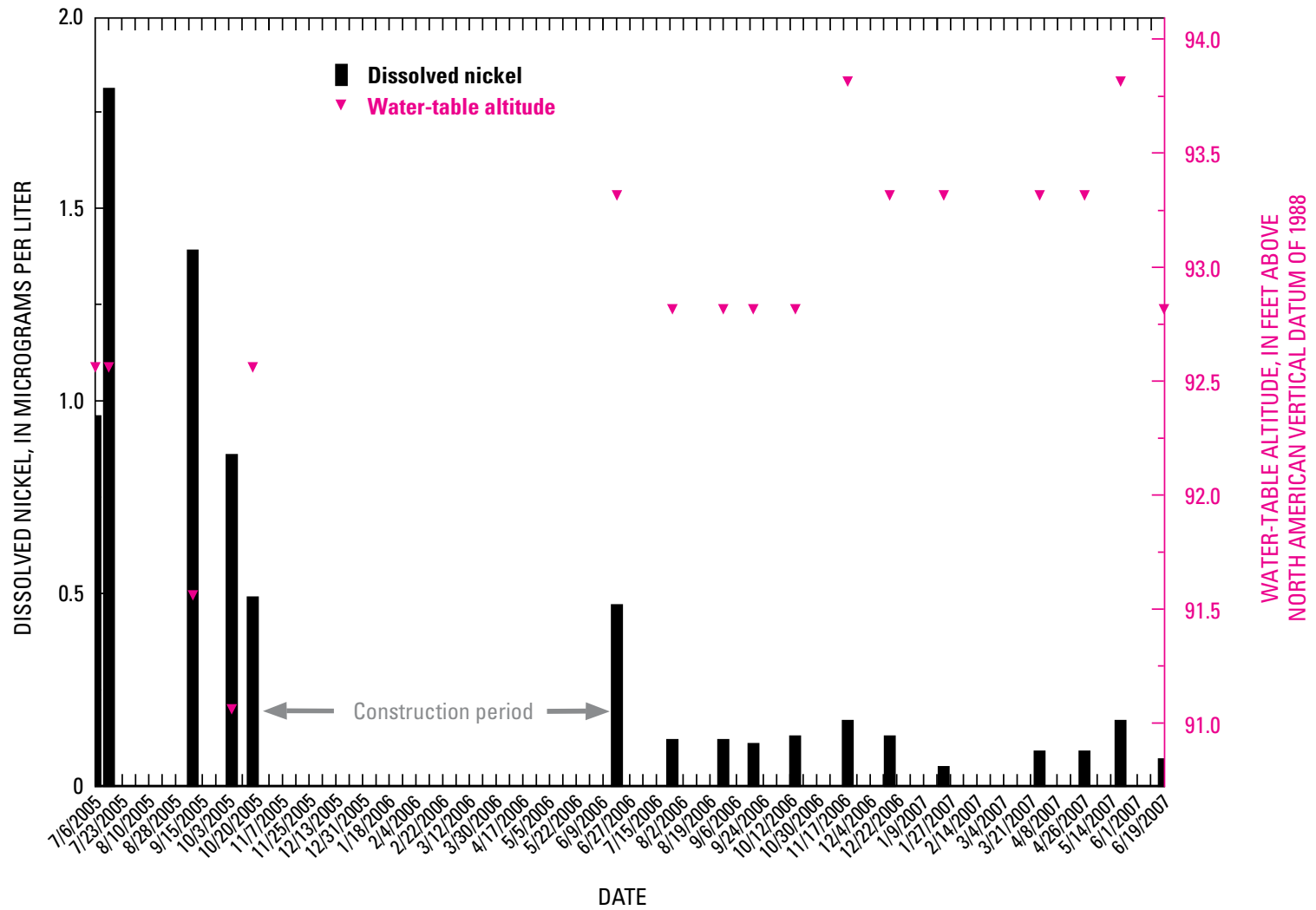

Figure 17. Dissolved nickel concentrations and water-table altitudes in multilevel-sampler well number 1 (MLS\#1) before and after installation of a porous parking lot at Silver Lake Beach, Wilmington, MA.

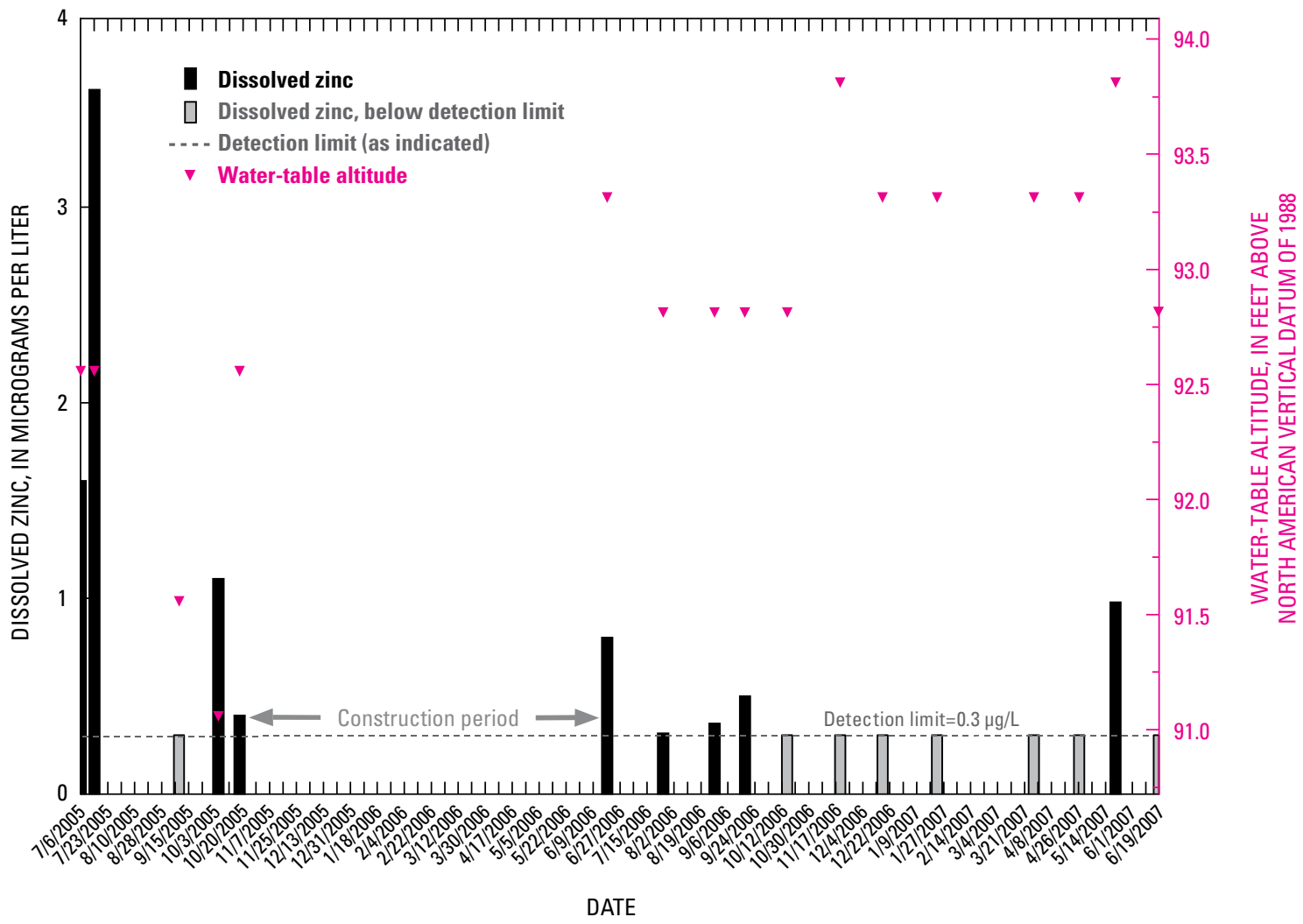

Figure 18. Dissolved zinc concentrations and water-table altitudes in multilevel-sampler well number 1 (MLS\#1) before and after installation of a porous parking lot at Silver Lake Beach, Wilmington, MA. Empty bar indicates nondetect. 


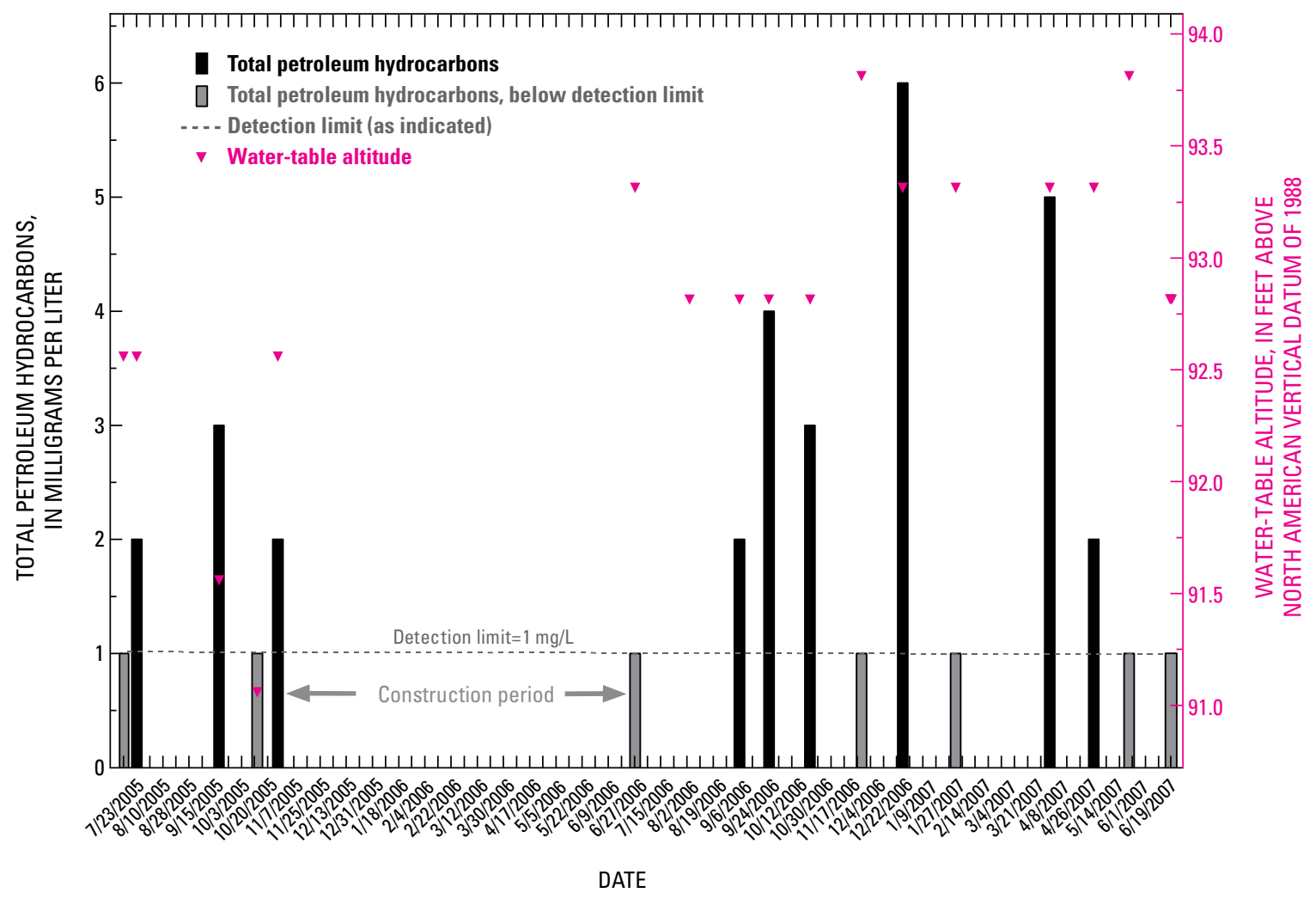

Figure 19. Total petroleum hydrocarbon concentration and water-table altitudes in multilevel-sampler well number 1 (MLS\#1) before and after installation of a porous parking lot at Silver Lake Beach, Wilmington, MA. Empty bars indicate nondetect.

quality may have been affected by contaminants infiltrating from street runoff.

For all three wells, the concentrations of dissolved nickel changed (declined) significantly (fig. 17). There is no clear, apparent cause for this change. Possible explanations are the removal of nickel from an upgradient source or from a source within the old parking lot during replacement. The Wilcoxon rank-sum test did not demonstrate any other significant changes in metal concentrations.

\section{Total Petroleum Hydrocarbons}

Prior to the installation of the porous parking lot, detections of total petroleum hydrocarbons (TPH) were not common; for the five sampling dates, TPH was only detected once in MLS\#2 or MLS\#3, and there were 3 detections in MLS\#1 (fig. 19, table 1). The TPH reporting level was $2 \mathrm{mg} / \mathrm{L}$. After the porous parking lot installation, there were more frequent TPH detections, with the highest concentration of $6 \mathrm{mg} / \mathrm{L}$ occurring once in each well. These differences were not statistically significant, however, possibly because of the small sample size.

\section{Low-Impact-Development Enhancements at the Silver Lake Avenue/Dexter Street Neighborhood and Water Quantity and Quality of Stormwater Runoff}

The primary objective of LID is to create, retain, or restore a hydrologic landscape that mimics natural hydrological conditions. Therefore, minimizing the effects of human alterations on hydrology by removing obstacles to natural infiltration, such as impervious asphalt or effectively impervious surfaces, is an obvious approach to hydrologic restoration in previously developed residential areas, such as the Silver Lake Avenue/Dexter Street neighborhood in Wilmington, MA (fig. 20). The desired effects of these retrofits were to decrease and delay runoff into storm sewers and other conveyances, thus enhancing infiltration and decreasing the mass, or loads, of transported contaminants and bacteria to Silver Lake.

The LID features designed for this neighborhood were not expected to substantially decrease nitrogen and phosphorus analyte concentrations, but rather to decrease the volume of runoff and, thus, diminish loads of nutrients, total metals, 


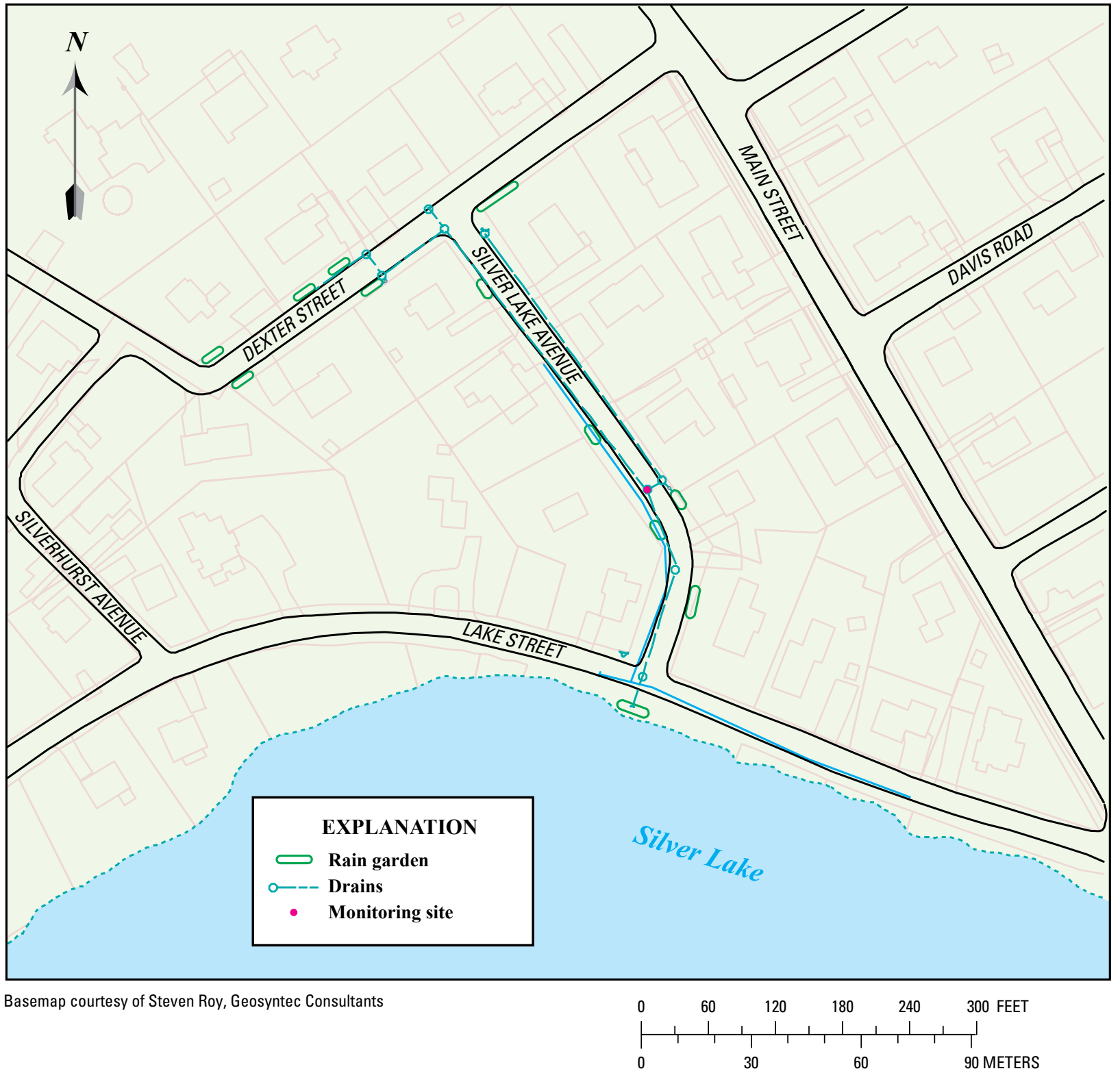

Figure 20. Silver Lake Avenue/Dexter Street neighborhood in Wilmington, MA, with drainage features and low-impactdevelopment enhancements. 
$\mathrm{TPH}$, and coliform bacteria, where load is defined as concentration multiplied by runoff volume. To measure such reductions accurately, the LID features would need to reduce runoff volumes by substantially more than measurement errors over a wide range of storm sizes. Additionally, runoff from an adequate number of storms of comparable precipitation before and after implementation would need to be sampled for water quality. Both of these conditions were difficult to meet within the field constraints and study length.

\section{Design of Low-Impact-Development Enhancements to Increase Infiltration}

The MDCR contracted with Geosyntec Consultants to design and install the LID enhancements in the Silver Lake Avenue/Dexter Street neighborhood; this work took place from December 2005 to June 2006, following approximately 5 months of monitoring the pre-LID-modification conditions. The neighborhood's total impervious area, including roads, driveways, and rooftops, accounted for 39 percent of the total 3.0-acre drainage area, as determined from the MassGIS 1-meter-resolution impervious surface datalayer (http://www.mass.gov/mgis/impervious_surface.htm, last accessed June 1, 2009).

LID enhancements, consisting of 12 pocket rain gardens along Dexter Street and Silver Lake Avenue and 2 strips of porous pavers along Silver Lake Avenue, were installed in the public right-of-way to increase stormwater infiltration from driveways and the street (figs. 21 to 23) and, hence, reduce the volume of direct stormwater runoff to Silver Lake. Underdrains from two of the porous-paved areas and overflow drains from rain gardens were connected to the existing storm-sewer system; stormwater entering these drains was monitored at the storm-sewer gage. The LID features roughly accounted for less than 2 percent of the 3 -acre neighborhood. Although the percentage of pervious surface created or enhanced by the LID features was not great, the enhancements were not designed just to receive and infiltrate direct rainfall, but to have runoff routed to them from most of the impervious surfaces, thus resulting in a greater effect on overall runoff than would be expected for the area of new pervious surface.

\section{Monitoring Approach}

The Silver Lake Avenue monitoring site consists of a 15-in. storm sewer that collects street runoff from the 3 -acre residential development. The storm sewer was outfitted with a 15-in. Thel-Mar, v-notch, volumetric weir and a Teledyne ISCO 4120 pressure transducer and datalogger (fig. 24). The transducer and logger controlled the Teledyne ISCO sampler that collected flow-proportional water samples (Edwards and Glysson, 1999). The transducer, weir, and sample intake were installed $2 \mathrm{ft}$ downstream from a manhole entry stormdrain grate (fig. 25) that was the most downstream location possible to monitor the runoff (refer to fig. 20 for location of monitoring site). A storage box containing the automated water sampler and datalogger was installed at the edge of the road, next to the catch basin; the autosampler was linked to the transducer that provided a signal to initiate sampling based on a preset volume of water that passed the weir. This trigger volume was determined from National Weather Service forecasts of precipitation and the calculated runoff expected to occur at the sampling site. Site visits were made monthly or during storm sampling to collect stormwater samples and to service the equipment.

Precipitation was monitored at a gage at Silver Lake beach and at the USGS Shawsheen River near Wilmington streamgage located $1.4 \mathrm{mi}$ away (fig. 1). The Shawsheen River precipitation gage was primarily used for data analysis but was supplemented with the Silver Lake precipitation gage because of occasional data losses. The correlation between precipitation recorded at the gages is strong $\left(\mathrm{R}^{2}=0.97\right)$.

All stage and precipitation data were processed in the USGS National Water Information System (NWIS) database, and the stage-discharge relation from the rated volumetric weir was used to calculate flow. The period of record started on August 22, 2005, and ended on December 5, 2007. Because of equipment malfunctions, four gaps in the stage data occurred during the period of record: (1) September 14 to October 2, 2006, (2) October 5 to October 25, 2006, (3) December 4 to December 6, 2006, and (4) April 22 to May 16, 2007. In addition, unreasonably high stages and calculated flows not consistent with precipitation records are attributed to debris on the weir or ice effects and were not used for analyses.

As stated previously, coliform bacteria in Silver Lake had historically caused beach closings during the summer. Although runoff from the Silver Lake Avenue side of the lake was not likely to have been associated with those closings, runoff was sampled for Escherichia coli (E. coli) and total coliform bacteria to test the potential of LID enhancements for diminishing bacterial concentrations in runoff.

The short holding-time requirement for obtaining valid bacteria samples was considered in determining the approach to sample collection. Holding times of 3 hours for bacteria and uncertain storm durations often made it necessary to collect multiple samples, representing fractions of the predicted storm runoff, rather than a single composite sample for the entire storm. The short holding time also meant that staff were often present throughout the storm-sampling period. The bacteriological samples were processed with a Colilert Quanti-Tray system (http://www.idexx.com/water/ products/quantitray/, last accessed April 2, 2009). After a bacterial sample was collected, a 100-milliliter subsample was removed and mixed with a reagent. To make serial dilutions, aliquots from the container with media were removed and added to another container with media; this process was repeated until the estimated numbers of bacteria became quantifiable. In general, two 1:10 or 1:100 dilutions were prepared routinely. Samples were incubated for 24 hours at $35^{\circ} \mathrm{C}$. Following incubation, the bacterial colonies were quantified using the Most Probable Number (MPN) model 

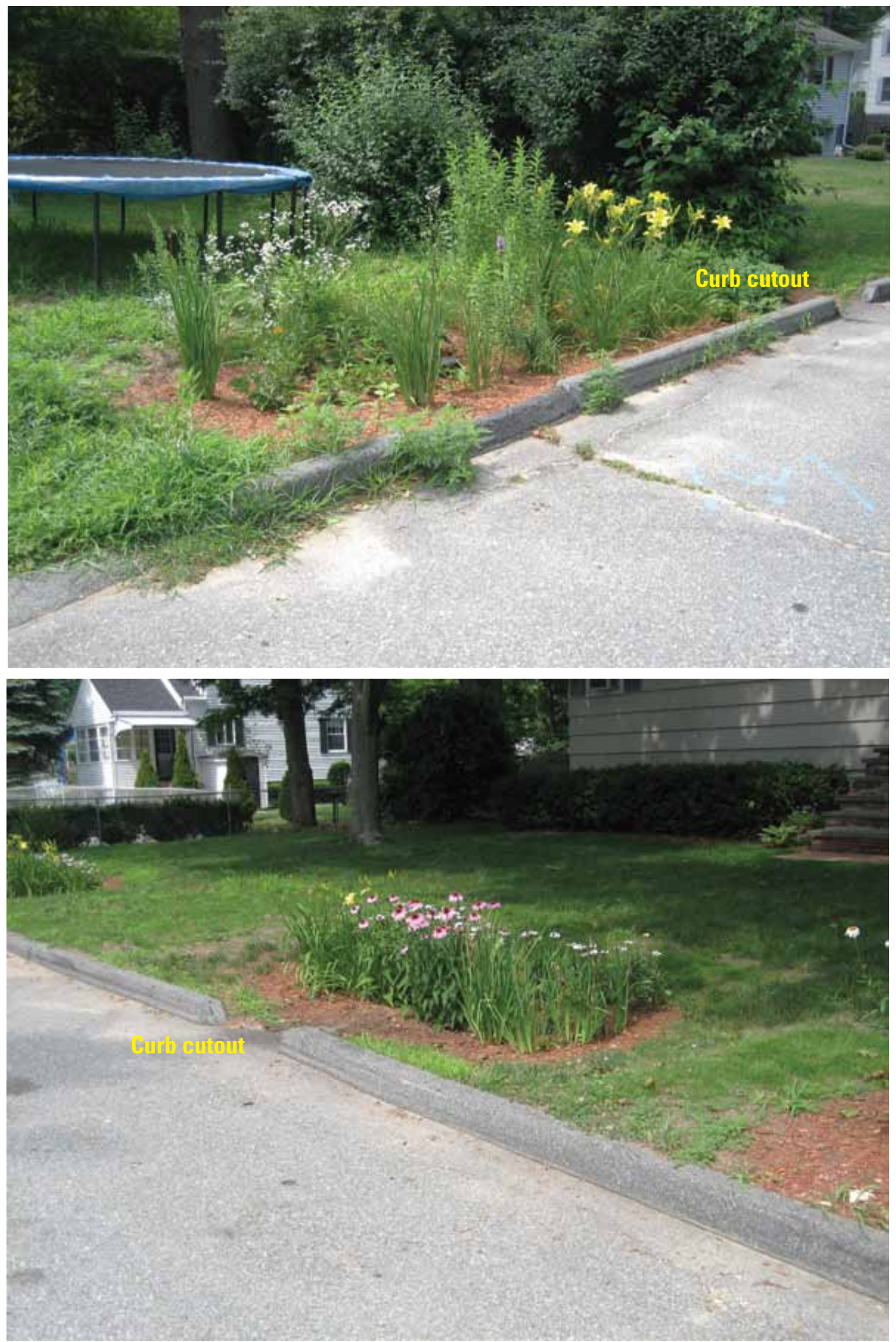

Figure 21. Rain gardens along Dexter Street, Wilmington, MA. Cutouts in curbs to direct runoff from road into rain garden. 


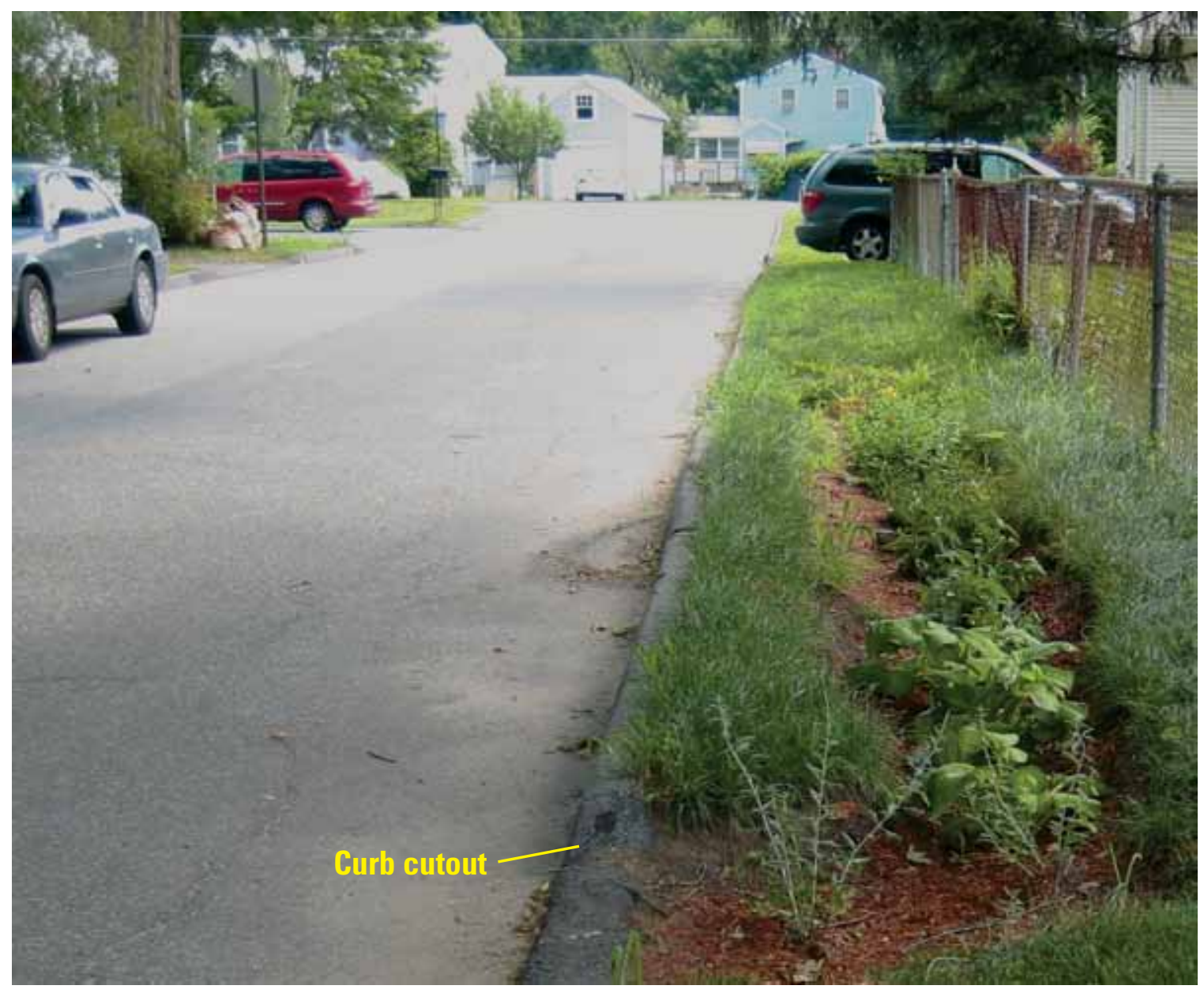

Figure 22. Rain garden along Dexter Street, Wilmington, MA. 


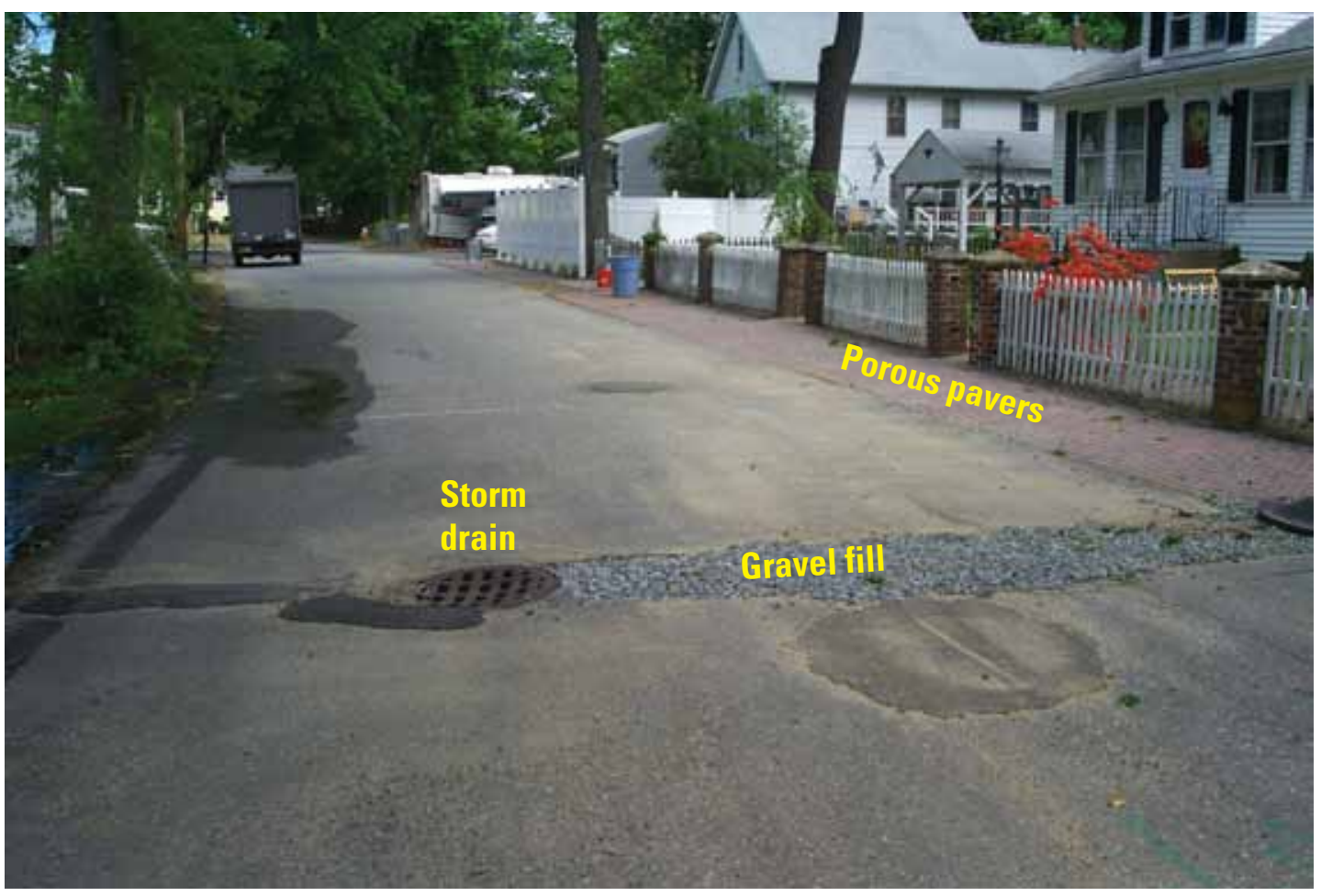

Figure 23. Storm drain at Silver Lake Avenue, Wilmington, MA. Gravel fill covers a pipe leading from the underflow collector beneath the porous-pavement section at right of photograph.

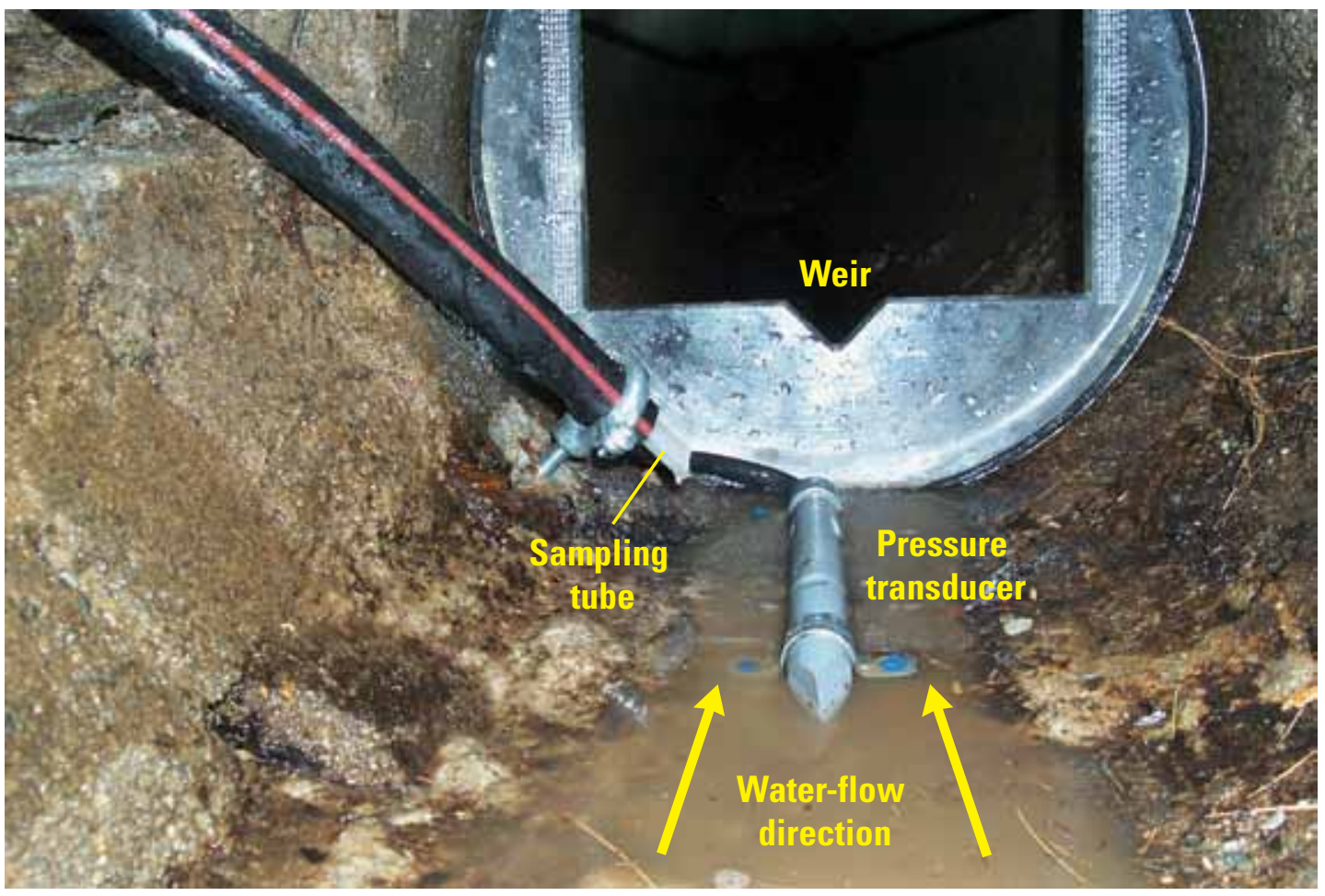

Figure 24. Runoff-monitoring equipment in a catch basin at Silver Lake Avenue, Wilmington, MA. A v-notch weir is mounted in the drain pipe behind a pressure transducer that lies on the bottom of the catch basin. An opaque Teflon sampling tube extends outward about 2 in. from the black, red-striped, protective tube. Water flows toward the pressure transducer and then over the weir. 


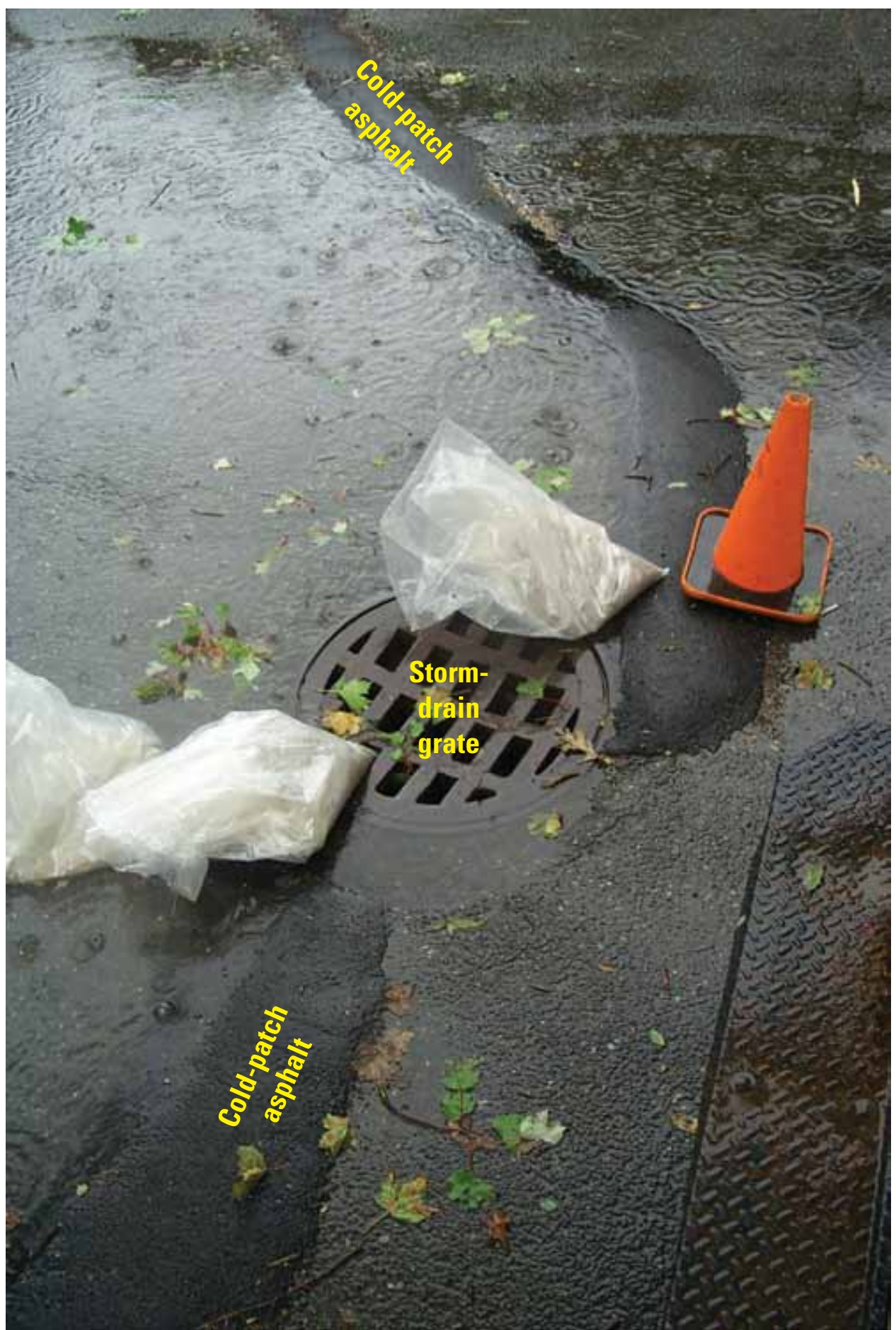

Figure 25. Water draining into a storm-drain grate on Silver Lake Avenue, Wilmington, MA. Cold-patch asphalt dams and sandbags were used to guide runoff to the grate. 
(http://oh.water.usgs.gov/micro/tce3.html, last accessed April 2, 2009).

The USGS monitored the water quantity and quality of storm runoff (concentrations of nutrients, total metals, TPH, and coliform bacteria) starting in August 2005; water-quality monitoring was suspended during the installation phase of LID retrofits (December 2005 to June 2006), restarted in July 2006, and completed in November 2007. Also, water-quality monitoring was not performed during the winter and early spring because of variable conditions associated with freezing, thawing, and snowfall. Changes in runoff volume and concentrations and loads of water-quality constituents were compared for the pre- and post-LID enhancement periods.

The Quality Assurance Project Plan (QAPP) called for the collection of six stormwater-quality samples during the 8-month period preceding the installation of LID enhancements and six stormwater samples following the LID installation. The limited time available prior to the LID modifications and the lack of storms that met the minimal sampling criteria resulted in five pre-LID sampling events; only 6 months were available for sampling during the pre-installation period (effectively, water-quality sampling was conducted for 3 months from August 30 to November 22). However, 10 post-LID storm samples were collected. Of the 10 post-LID storms, irregularities in the flows invalidated the results for one sample set; bacteriological samples were not collected for all storms.

Four quality-control, replicate, and blank samples were collected (table 2). With the exceptions of the $\mathrm{Cd}$ (22.2 percent) and nitrite (120 percent) relative percent differences (RPDs), RPDs were within the measurement criterion of 20 percent; the high RPD samples were still low in concentration. Most blank samples were clean or detections were at concentrations close to the reporting level.

\section{Changes in Runoff Quantity and Quality Following Installation of Low-Impact-Development Enhancements}

At Silver Lake Avenue, changes in pre- and post-LID stormwater-runoff quantity and quality were small, subtle, and complicated by differences in climatic conditions and by changes in drainage infrastructure.

\section{Runoff Quantity}

To compare pre- and post-LID changes in runoff, the data were examined for all storms associated with measured runoff. For storms determined to have data acceptable for analysis, rainfall and runoff relations were determined. In addition to considering all storms, the storms were also sub-divided by time of year, storm size (inches of rainfall), and antecedent dry period.

Pre- and post-LID rainfall-runoff coefficients ${ }^{1}$ (RRs) were examined to assess the effectiveness of the LID installations; RRs were further examined by sorting storms by total precipitation and antecedent dry period. When all acceptable pre- and post-LID storms were considered, no significant differences between median RR values were detected, even for storms with antecedent dry period exceeding 100 hours (figs. 26A, B). Sorting storms into four size classes also did not reveal any statistically significant differences between pre- and post-LID RRs; however, median RRs did indicate a difference between pre- and post-LID storms, as the storm size decreased (fig. 27). Specifically, the differences in median runoff coefficients were greatest in the category of smallest storms (less than $0.25 \mathrm{in}$.), where the pre-LID median of the runoff coefficients was slightly greater than 0.1 and the post-LID median was about 0.045. Using the median of the rainfall-runoff curve for the smallest class of storms as a surrogate for the effective impervious area (EIA) (Zarriello and Barlow, 2002; Jennings and Doyle, 1978), the pre-LID EIA was about 10 percent, and the post-LID EIA was approximately 4.5 percent (fig. 28).

Another difference was the occurrence of zero runoff from several post-installation storms; these storms were all of 0.20 in. or less of precipitation (fig. 29). Of the 21 postinstallation storms with 0.25 in. or less precipitation, 7 , or 33 percent, produced no measurable runoff. Of the seven preinstallation storms of 0.26 in. of rainfall or less, all had some measurable runoff. No specific factor, such as antecedent dry period or storm duration or intensity, seemed to be associated with the absence or presence of runoff. These results indicate that even relatively small-scale changes in EIA, in an area underlain by highly porous soils, can produce measurable changes in runoff, if the storms do not exceed a size threshold; in the case of this study site, that threshold was about 0.20 in. of precipitation, which included 56 percent of all pre- and post-LID storms,.

${ }^{1}$ The unitless runoff coefficient is the depth, in inches, of the total volume of runoff distributed evenly over the drainage-area surface, divided by the depth of precipitation, in inches. 


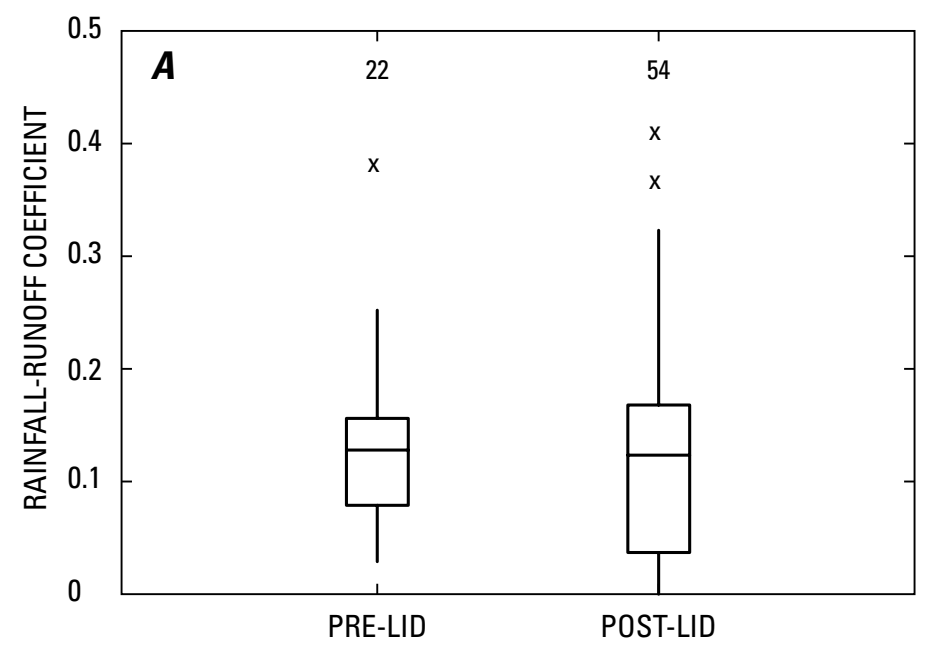

\section{EXPLANATION}

22 Number of samples

$0 \quad$ Data value greater than 3.0 times the interquartile range above the box

$x \quad$ Data value 1.5 to 3.0 times the interquartile range above the box

Largest data value within 1.5 times the interquartile range above the box

\section{5th percentile}

Median (50th percentile)

25th percentile

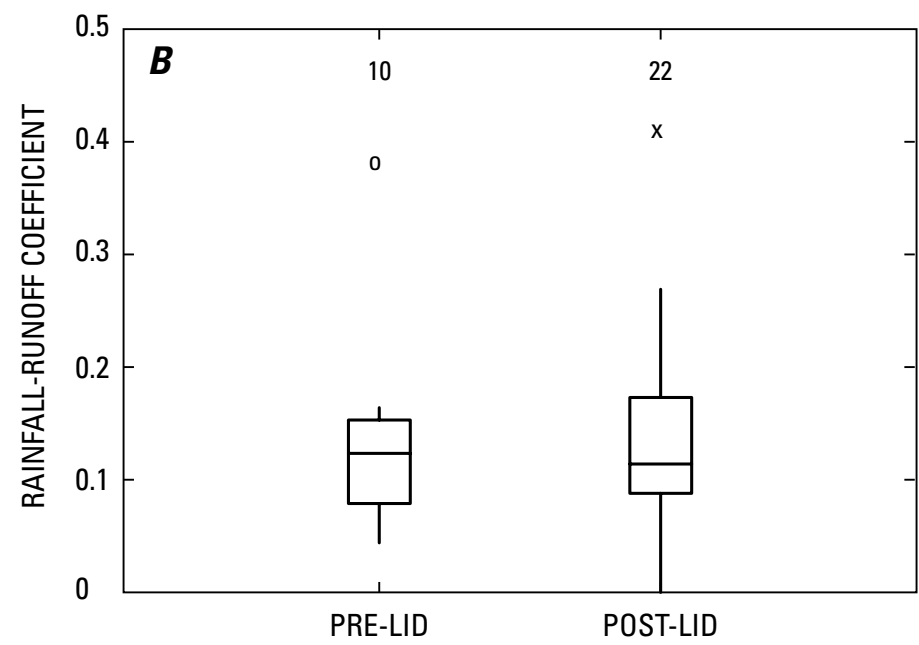

Smallest data value within 1.5 times the interquartile range below the box

Figure 26. Rainfall-runoff coefficients determined before (Pre-LID, Aug. 2005-Feb. 2006) and after (Post-LID, Aug. 2006-Nov. 2007) installation of low-impact-development features along Silver Lake Avenue, Wilmington, $M A$, for $(A)$ all storms monitored during the study period and $(B)$ monitored storms preceded by 100 hours or more of dry conditions. LID, low-impact development. 
PRECIPITATION DEPTH

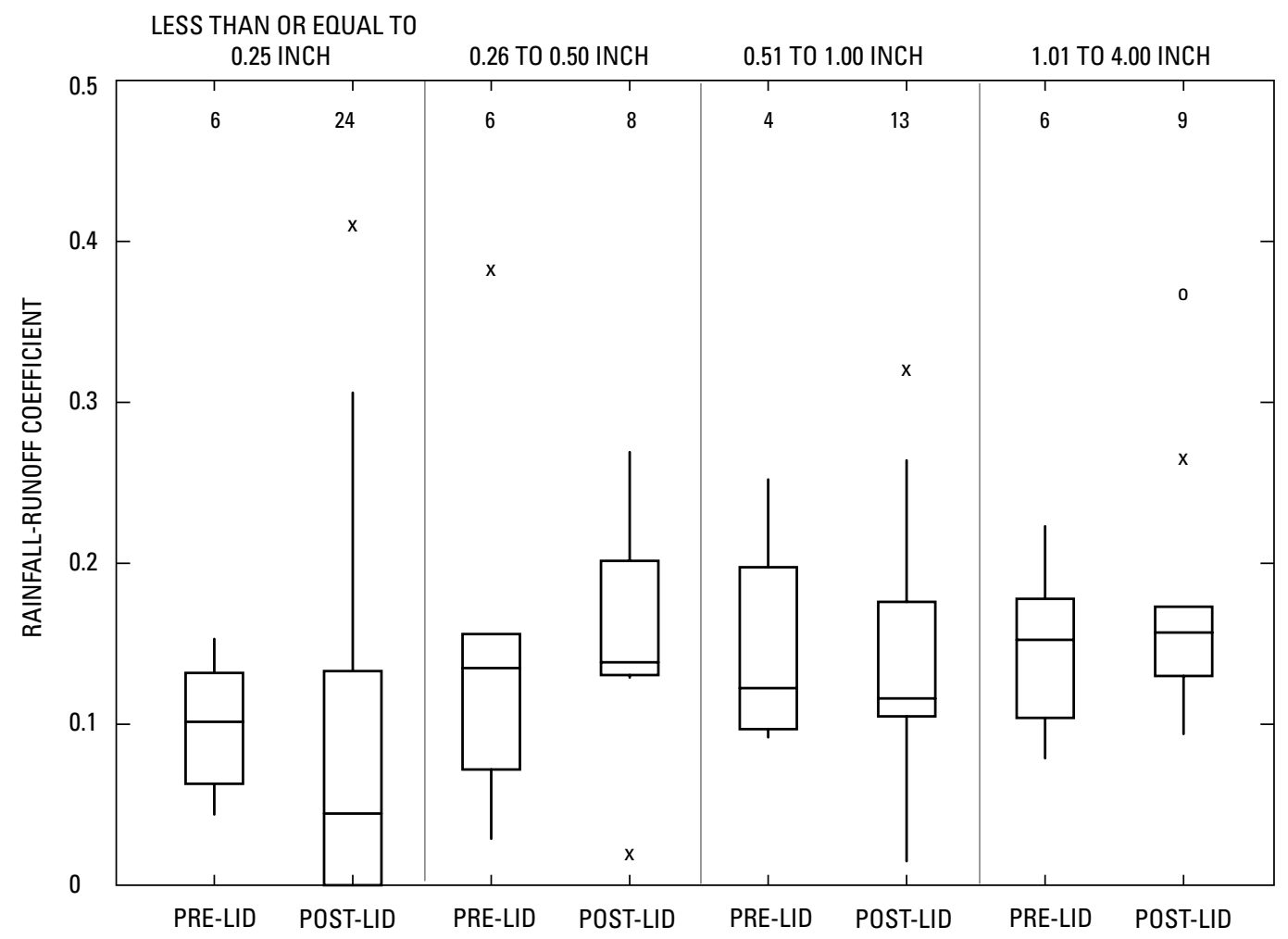

EXPLANATION

$24 \quad$ Number of samples

0 Data value greater than 3.0 times the interquartile range above the box

$x \quad$ Data value 1.5 to 3.0 times the interquartile range above the box

Largest data value within 1.5 times the interquartile range above the box

75th percentile

Median (50th percentile)

25th percentile

Smallest data value within 1.5 times the interquartile range below the box

$x \quad$ Data value 1.5 to 3.0 times the interquartile range below the box

Figure 27. Rainfall-runoff coefficients determined before (Pre-LID, Aug. 2005-Feb. 2006) and after (Post-LID, Aug. 2006-Nov. 2007) installation of low-impact-development features along Silver Lake Avenue, Wilmington, MA, for groups of storms with different amounts of precipitation. LID, low-impact development. 


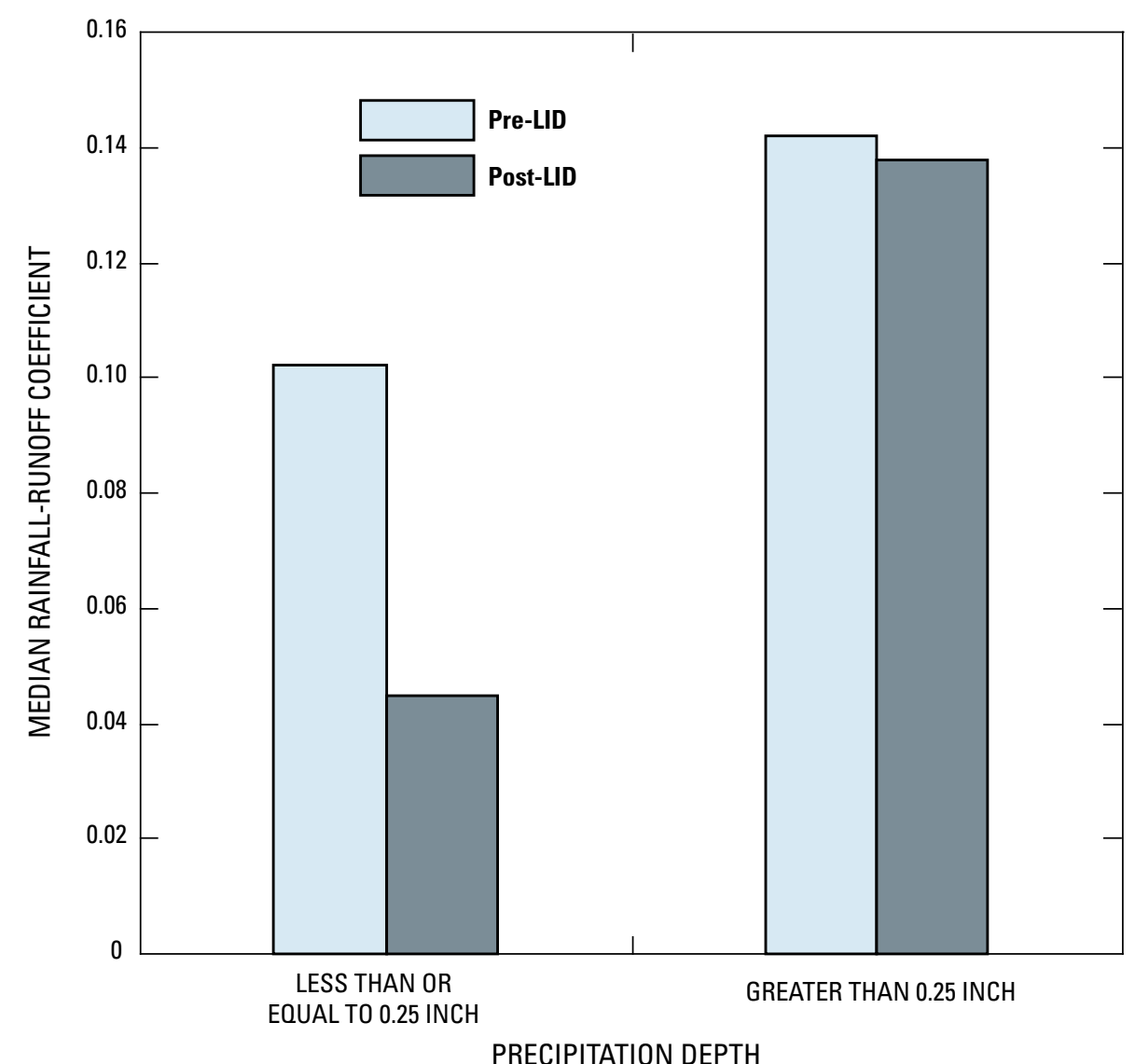

PRECIPITATION DEPTH

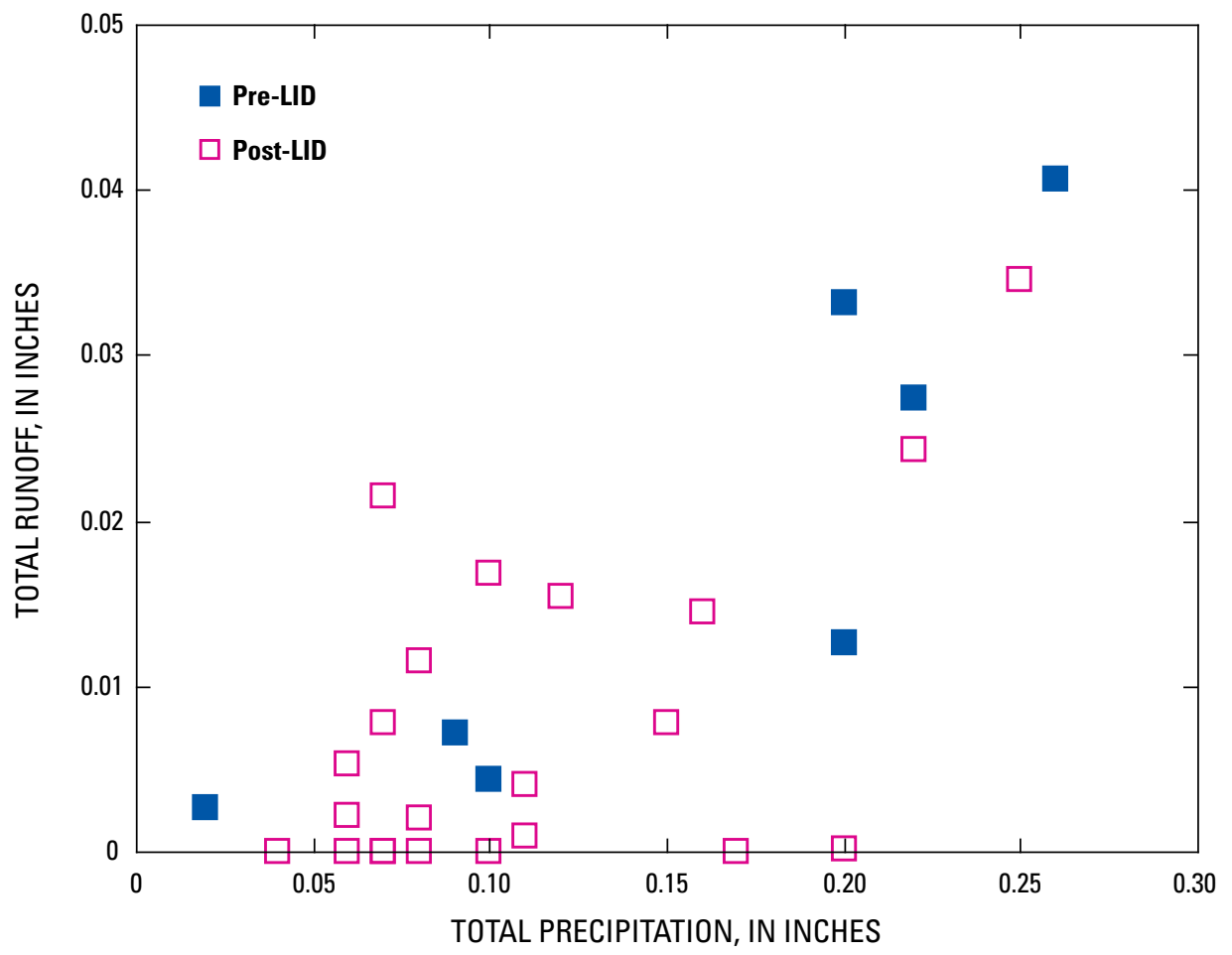

Figure 28. Median rainfall-runoff coefficients determined before (Pre-LID, Aug. 2005-Feb. 2006) and after (PostLID, Aug. 2006-Nov. 2007) installation of low-impact-development features along Silver Lake Avenue, Wilmington, MA, for storms with greater than and less than or equal to 0.25 inch of precipitation.

Figure 29. Relations between total runoff and total precipitation for storms with total precipitation less than 0.26 inch that occurred before (Pre-LID, Aug. 2005-Feb. 2006) and after (Post-LID, Aug. 2006-Nov. 2007) installation of low-impactdevelopment features along Silver Lake Avenue, Wilmington, MA. 


\section{Runoff Quality}

Water-quality constituent concentrations were almost always greater than detection levels (table 4); the only exception was TPH with 50 percent nondetects (concentrations less than the $2 \mathrm{mg} / \mathrm{L}$ detection limit). For the creation of concentration boxplots and calculation of loads, rare non-detects were replaced with values equal to one-half of their respective detection limits; the resulting nutrient loads were the smallest calculated; the single metal non-detect replaced in this manner resulted in a load equal to the lower quartile.

The pre- and post-installation nutrient (nitrogen and phosphorus) and metal analyte concentrations were not statistically different when evaluated with the Wilcoxon rank-sum test; the small numbers of samples made it unlikely that the generally small differences would be significantly different. Post-installation median concentrations of nitrogen and metal analytes were larger or about the same as pre-installation concentrations. The median concentrations of orthophosphorus and dissolved phosphorus $(0.180$ and $0.280 \mathrm{mg} / \mathrm{L}$ as $\mathrm{P}$, respectively, before installation) decreased after LID installation $(0.128$ and $0.243 \mathrm{mg} / \mathrm{L}$ as $\mathrm{P}$, respectively), and the median total phosphorus concentration increased slightly (from 0.400 to $0.47 \mathrm{mg} / \mathrm{L}$ as $\mathrm{P}$ ). The MPN of total coliform bacteria in preand post-LID runoff ranged widely and was not significantly different when evaluated with the Wilcoxon rank-sum test.
Pre- and post-LID estimated loads of nutrients, metals, $\mathrm{TPH}$, and coliform bacteria to Silver Lake did not change in a consistent manner (table 5); moreover, none of the changes in pre- and post-LID median loads for any of the chemical and biological constituents were statistically significant. The calculated median values of loads of all nitrogen-containing analytes increased (fig. 30). Median values of loads of phosphorus-containing analytes decreased (fig. 31). Among the metal analytes $\mathrm{Pb}$ and $\mathrm{Zn}$, median values of loads decreased, and the median values of loads of other metals increased (fig. 32). The median value of the loads of total coliform bacteria increased slightly and the median value of the loads of E. coli decreased somewhat.

The differences, or lack thereof, in the chemical and biological properties of pre- and post-LID storms may be a result of the storm sizes sampled. The median precipitation of the storms sampled after installation of the LID features was more than twice the pre-LID median storm precipitation ( 0.77 and 0.36 in., respectively). A larger decrease in EIA would have made it more likely that changes in loads would have been detected. Moreover, the non-point nature of the runoff and the potential sources of the material, such as seasonal or, perhaps random, vegetation fertilization and animal and automotiveassociated contamination make it difficult to detect the effects of small changes in EIA during a short study period. 
Table 4. Concentrations of nutrients, total metals, total petroleum hydrocarbons, total coliform bacteria, and $E$. coli in samples collected at the Silver Lake Avenue runoff site in Wilmington, MA, 2005-07.

[E, estimated value less than the reporting level; <, less than; shading indicates samples collected prior to installation of low impact development enhancements; L, sample lost during processing; MPN, most probable number; >, greater than; ns, sample not collected]

\begin{tabular}{|c|c|c|c|c|c|c|c|c|c|}
\hline \multirow[b]{2}{*}{$\begin{array}{l}\text { Sampling } \\
\text { date }\end{array}$} & \multicolumn{9}{|c|}{ Nutrients (concentrations in milligrams per liter) } \\
\hline & $\begin{array}{c}\text { Dissolved } \\
\text { ammonia plus } \\
\text { organic nitrogen, } \\
\text { as N }\end{array}$ & \multicolumn{2}{|c|}{$\begin{array}{c}\text { Total ammonia } \\
\text { plus organic } \\
\text { nitrogen, } \\
\text { as N }\end{array}$} & $\begin{array}{c}\text { Dissolved } \\
\text { ammonia, } \\
\text { as N }\end{array}$ & $\begin{array}{c}\text { Dissolved } \\
\text { nitrate plus } \\
\text { nitrite, } \\
\text { as } \mathbf{N}\end{array}$ & $\begin{array}{l}\text { Dissolved } \\
\text { nitrite, } \\
\text { as } N\end{array}$ & $\begin{array}{c}\text { Orthophos- } \\
\text { phorus, } \\
\text { as P }\end{array}$ & $\begin{array}{c}\text { Dissolved } \\
\text { phosphorus, } \\
\text { as P }\end{array}$ & $\begin{array}{c}\text { Total } \\
\text { phosphorus }\end{array}$ \\
\hline $8 / 30 / 2005$ & 0.88 & \multicolumn{2}{|l|}{1.3} & 0.27 & 0.44 & 0.014 & 0.230 & 0.280 & 0.400 \\
\hline $9 / 15 / 2005$ & 2.2 & \multicolumn{2}{|l|}{2.8} & 0.45 & 0.68 & 0.027 & 0.270 & 0.440 & 0.600 \\
\hline $9 / 29 / 2005$ & 0.79 & \multicolumn{2}{|l|}{1.7} & 0.17 & 0.33 & E.007 & 0.180 & 0.230 & 0.400 \\
\hline $10 / 8 / 2005$ & 0.76 & \multicolumn{2}{|l|}{1.2} & 0.05 & $<.06$ & $<.008$ & 0.150 & 0.240 & 0.410 \\
\hline $11 / 22 / 2005$ & 0.23 & \multicolumn{2}{|c|}{0.56} & $<.04$ & 0.14 & E.005 & 0.070 & 0.108 & 0.186 \\
\hline Median & 0.79 & \multicolumn{2}{|l|}{1.3} & 0.17 & 0.33 & $<.008$ & 0.180 & 0.240 & 0.400 \\
\hline $8 / 21 / 2006$ & 0.46 & \multicolumn{2}{|l|}{0.6} & 0.071 & 0.19 & 0.006 & 0.128 & 0.170 & 0.220 \\
\hline $11 / 8 / 2006$ & 1.1 & \multicolumn{2}{|l|}{1.3} & $<.020$ & 0.28 & 0.003 & 0.395 & 0.675 & 0.710 \\
\hline $11 / 24 / 2006$ & 0.22 & \multicolumn{2}{|c|}{0.27} & 0.051 & 1.86 & 0.007 & 0.021 & 0.028 & 0.046 \\
\hline $12 / 1 / 2006$ & 0.62 & \multicolumn{2}{|l|}{2.2} & 0.127 & 0.56 & 0.011 & 0.013 & 0.033 & 0.500 \\
\hline $5 / 16 / 2007$ & 1.9 & \multicolumn{2}{|l|}{2.2} & 0.399 & 0.97 & 0.008 & 0.031 & 0.301 & 0.339 \\
\hline 6/9/2007 & 1.6 & 2.9 & & 0.562 & 1.55 & 0.027 & 0.045 & 0.084 & 0.337 \\
\hline $8 / 6 / 2007$ & 1.8 & 2.7 & & 0.653 & 1.06 & 0.02 & 0.177 & 0.243 & 0.470 \\
\hline $9 / 28 / 2007$ & 5.5 & 7.9 & & 2.32 & 3.58 & 0.736 & 0.223 & 0.360 & 0.780 \\
\hline $11 / 3 / 2007$ & 0.59 & 1.2 & & $<.020$ & $<.04$ & 0.003 & 0.349 & 0.410 & 0.550 \\
\hline Median & 1.1 & 2.2 & & 0.127 & 0.72 & 0.008 & 0.128 & 0.243 & 0.47 \\
\hline & Total & metals (con & entratio & ons in microg & ams per liter) & Tota & petroleum & Total coliforms & $s$ and $E$. coli \\
\hline $\begin{array}{l}\text { Sampling } \\
\text { date }\end{array}$ & Cadmium & Chromium & Copper & Lead & Nickel & $\begin{array}{r}\text { hyd } \\
\text { (con } \\
\text { in n } \\
p\end{array}$ & $\begin{array}{l}\text { ocarbons } \\
\text { entrations } \\
\text { illigrams } \\
\text { ar liter) }\end{array}$ & $\begin{array}{l}\text { Total coliform } \\
\text { bacteria } \\
\text { (MPN per } \\
100 \mathrm{~mL} \text { ) } \\
\end{array}$ & $\begin{array}{l}\text { Total E. coli } \\
\text { (MPN per } \\
100 \mathrm{~mL} \text { ) }\end{array}$ \\
\hline $8 / 30 / 2005$ & 0.06 & E2 & 8.1 & 6.51 & 2.24 & 31 & $<2$ & $>242,000$ & 48,700 \\
\hline $9 / 15 / 2005$ & 0.17 & 4 & 17.5 & 10 & 4.2 & 76 & $<2$ & 630,000 & 10,400 \\
\hline $9 / 29 / 2005$ & 0.13 & 3 & 9.4 & 9.59 & 2.33 & 41 & 2 & 715,000 & 7,470 \\
\hline $10 / 8 / 2005$ & 0.11 & E1 & 11.1 & 5.11 & 2.19 & 53 & $<2$ & 1,320 & 67.0 \\
\hline $11 / 22 / 2005$ & 0.06 & E1 & 4.5 & 5.15 & 1.3 & 24 & 2 & 19,700 & 15,000 \\
\hline Median & 0.11 & E2 & 9.4 & 6.51 & 2.24 & 41 & $<2$ & $>242,000$ & 10,400 \\
\hline $8 / 21 / 2006$ & E0.03 & $<2$ & 6.8 & 3.09 & 0.97 & 13 & 3 & 1,250 & 29.0 \\
\hline $11 / 8 / 2006$ & 0.04 & $\mathrm{~L}$ & 6 & 1.4 & 1.57 & 37 & $<2$ & ns & $\mathrm{ns}$ \\
\hline $11 / 24 / 2006$ & 0.07 & 2 & 3.1 & 1.07 & 0.66 & 9 & 3 & $\mathrm{~ns}$ & $\mathrm{~ns}$ \\
\hline $12 / 1 / 2006$ & 0.18 & 7 & 24.7 & 39.9 & 4.71 & 57 & 6 & $\mathrm{~ns}$ & $\mathrm{~ns}$ \\
\hline $5 / 16 / 2007$ & 0.12 & 4 & 10.3 & 12.8 & 3 & 39.1 & $<2$ & 51,100 & 28.0 \\
\hline 6/9/2007 & 0.20 & 2 & 10.7 & 7.84 & 3.2 & 42.1 & 2 & 381,000 & 4,130 \\
\hline 8/6/2007 & 0.13 & 3 & 12.6 & 8.34 & 3.5 & 60.6 & $\mathrm{~L}$ & 690,000 & 17,000 \\
\hline $9 / 28 / 2007$ & 0.17 & 2 & 26.7 & 7.01 & 5.3 & 132 & $<2$ & $1,860,000$ & 2,550 \\
\hline $11 / 3 / 2007$ & 0.10 & 5 & 22.3 & 3.7 & 8.8 & 62.2 & $<2$ & $\mathrm{~ns}$ & $\mathrm{~ns}$ \\
\hline Median & 0.11 & 2 & 10.7 & 7.01 & 3.2 & 42.1 & 2 & 381,000 & 2,550 \\
\hline
\end{tabular}


Table 5. Estimated loads of nutrients, total metals, total petroleum hydrocarbons, total coliform bacteria, and E. coli in samples collected at the Silver Lake Avenue runoff site in Wilmington, MA, 2005-07.

[Shading indicates samples collected prior to installation of low-impact-development enhancements; --, sample lost during processing; MPN, most probable number; ns, sample not collected]

\begin{tabular}{|c|c|c|c|c|c|c|c|c|c|c|}
\hline \multirow[b]{2}{*}{$\begin{array}{l}\text { Sampling } \\
\text { date }\end{array}$} & \multicolumn{10}{|c|}{ Nutrients (grams) } \\
\hline & \multicolumn{2}{|c|}{$\begin{array}{c}\text { Dissolved } \\
\text { ammonia plus } \\
\text { organic nitrogen, } \\
\text { as N }\end{array}$} & \multirow{2}{*}{ 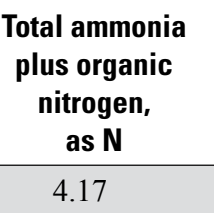 } & $\begin{array}{c}\text { Dissolved } \\
\text { ammonia, } \\
\text { as } \mathbf{N}\end{array}$ & \multicolumn{2}{|c|}{$\begin{array}{c}\text { Dissolved } \\
\text { nitrate plus } \\
\text { nitrite, } \\
\text { as N } \\
\end{array}$} & $\begin{array}{l}\text { Jissolved } \\
\text { nitrite, } \\
\text { as N }\end{array}$ & $\begin{array}{c}\text { Orthophos } \\
\text { phorus, } \\
\text { as } P\end{array}$ & $\begin{array}{c}\text { Dissolved } \\
\text { phosphorus, } \\
\text { as } \mathbf{P}\end{array}$ & $\begin{array}{c}\text { Total } \\
\text { phosphorus }\end{array}$ \\
\hline $8 / 30 / 2005$ & 2.83 & & & 0.87 & & 41 & 0.04 & 0.74 & 0.90 & 1.28 \\
\hline $9 / 15 / 2005$ & 34.42 & & 43.80 & 7.04 & & & 0.42 & 4.22 & 6.88 & 9.39 \\
\hline $9 / 29 / 2005$ & 9.71 & & 20.89 & 2.09 & & & 0.09 & 2.21 & 2.83 & 4.92 \\
\hline $10 / 8 / 2005$ & 0.35 & & 0.55 & 0.02 & & 03 & 0.00 & 0.07 & 0.11 & 0.19 \\
\hline $11 / 22 / 2005$ & 5.59 & & 13.61 & 0.97 & & 40 & 0.12 & 1.70 & 2.62 & 4.52 \\
\hline Median & 5.59 & & 13.61 & 0.97 & & 40 & 0.09 & 1.70 & 2.62 & 4.52 \\
\hline $8 / 21 / 2006$ & 6.71 & & 8.76 & 1.04 & & 77 & 0.09 & 1.87 & 2.48 & 3.21 \\
\hline $11 / 8 / 2006$ & 49.49 & & 58.48 & 0.90 & & & 0.13 & 17.77 & 30.37 & 31.94 \\
\hline $11 / 24 / 2006$ & 10.60 & & 13.00 & 2.46 & & & 0.34 & 1.01 & 1.35 & 2.22 \\
\hline $12 / 1 / 2006$ & 20.58 & & 73.02 & 4.22 & & & 0.37 & 0.43 & 1.10 & 16.60 \\
\hline $5 / 16 / 2007$ & 42.44 & & 49.15 & 8.91 & & & 0.18 & 0.69 & 6.72 & 7.57 \\
\hline $6 / 9 / 2007$ & 11.98 & & 21.72 & 4.21 & & & 0.20 & 0.34 & 0.63 & 2.52 \\
\hline $8 / 6 / 2007$ & 4.31 & & 6.46 & 1.56 & & 54 & 0.05 & 0.42 & 0.58 & 1.12 \\
\hline $9 / 28 / 2007$ & 9.50 & & 13.64 & 4.01 & & 18 & 1.27 & 0.39 & 0.62 & 1.35 \\
\hline $11 / 3 / 2007$ & 35.19 & & 71.57 & 1.19 & & 39 & 0.18 & 20.82 & 24.45 & 32.80 \\
\hline Median & 11.98 & & 21.72 & 2.46 & & & 0.18 & 0.69 & 1.35 & 3.21 \\
\hline \multirow[b]{2}{*}{$\begin{array}{l}\text { Sampling } \\
\text { date }\end{array}$} & \multicolumn{6}{|c|}{ Total metals (milligrams) } & \multirow{2}{*}{\multicolumn{2}{|c|}{$\begin{array}{c}\text { Total } \\
\text { petroleum } \\
\text { hydrocarbons } \\
\text { (grams) }\end{array}$}} & \multicolumn{2}{|c|}{ Total coliforms and $E$. coli } \\
\hline & Cadmium & Chromium & Copper & Lead & Nickel & Zinc & & & $\begin{array}{l}\text { Total coliform } \\
\text { bacteria } \\
\text { (MPN) }\end{array}$ & $\begin{array}{c}\text { Total E. coli } \\
\text { (MPN) }\end{array}$ \\
\hline $8 / 30 / 2005$ & 0.19 & 6.42 & 26.01 & 20.90 & 7.19 & 99.55 & & 6.42 & $7,770,000,000$ & $1,560,000,000$ \\
\hline $9 / 15 / 2005$ & 2.66 & 62.58 & 273.77 & 156.44 & 65.70 & $1,188.95$ & & 1.29 & $98,500,000,000$ & $1,620,000,000$ \\
\hline $9 / 29 / 2005$ & 1.60 & 36.87 & 115.52 & 117.85 & 28.63 & 503.85 & & 4.58 & $87,800,000,000$ & $918,000,000$ \\
\hline $10 / 8 / 2005$ & 0.05 & 0.46 & 5.11 & 2.35 & 1.01 & 24.41 & & 0.92 & $6,090,000$ & 309,000 \\
\hline $11 / 22 / 2005$ & 1.46 & 24.30 & 109.37 & 125.17 & 31.60 & 583.31 & & 8.61 & $4,790,000,000$ & $365,000,000$ \\
\hline Median & 1.46 & 24.30 & 109.37 & 117.85 & 28.63 & 301.70 & & 4.58 & $7,770,000,000$ & $918,000,000$ \\
\hline $8 / 21 / 2006$ & 0.44 & 29.19 & 99.26 & 45.10 & 14.16 & 189.76 & & 3.79 & $182,000,000$ & $4,300,000$ \\
\hline $11 / 8 / 2006$ & 1.80 & -- & 269.92 & 62.98 & 70.63 & $1,664.52$ & & 9.97 & ns & $\mathrm{ns}$ \\
\hline $11 / 24 / 2006$ & 3.37 & 96.32 & 149.29 & 51.53 & 31.79 & 433.43 & & 4.48 & ns & $\mathrm{ns}$ \\
\hline $12 / 1 / 2006$ & 5.97 & 232.34 & 819.83 & $1,324.33$ & 156.33 & $1,891.91$ & & 9.15 & ns & $\mathrm{ns}$ \\
\hline $5 / 16 / 2007$ & 2.68 & 89.36 & 230.09 & 285.94 & 67.02 & 873.46 & & 4.68 & $11,400,000,000$ & $6,200,000$ \\
\hline $6 / 9 / 2007$ & 1.50 & 14.98 & 80.13 & 58.71 & 23.96 & 315.28 & & 4.98 & $28,600,000,000$ & $310,000,000$ \\
\hline $8 / 6 / 2007$ & 0.31 & 7.18 & 30.15 & 19.96 & 8.38 & 145.02 & & -- & $16,500,000,000$ & $407,000,000$ \\
\hline $9 / 28 / 2007$ & 0.29 & 3.45 & 46.10 & 12.10 & 9.15 & 227.90 & & 3.45 & $32,100,000,000$ & $44,000,000$ \\
\hline $11 / 3 / 2007$ & 5.96 & 298.22 & $1,330.08$ & 223.67 & 524.87 & $3,709.90$ & & 9.29 & ns & $\mathrm{ns}$ \\
\hline Median & 1.80 & 59.28 & 124.28 & 55.12 & 31.79 & 271.59 & & 7.33 & $16,500,000,000$ & $44,000,000$ \\
\hline
\end{tabular}




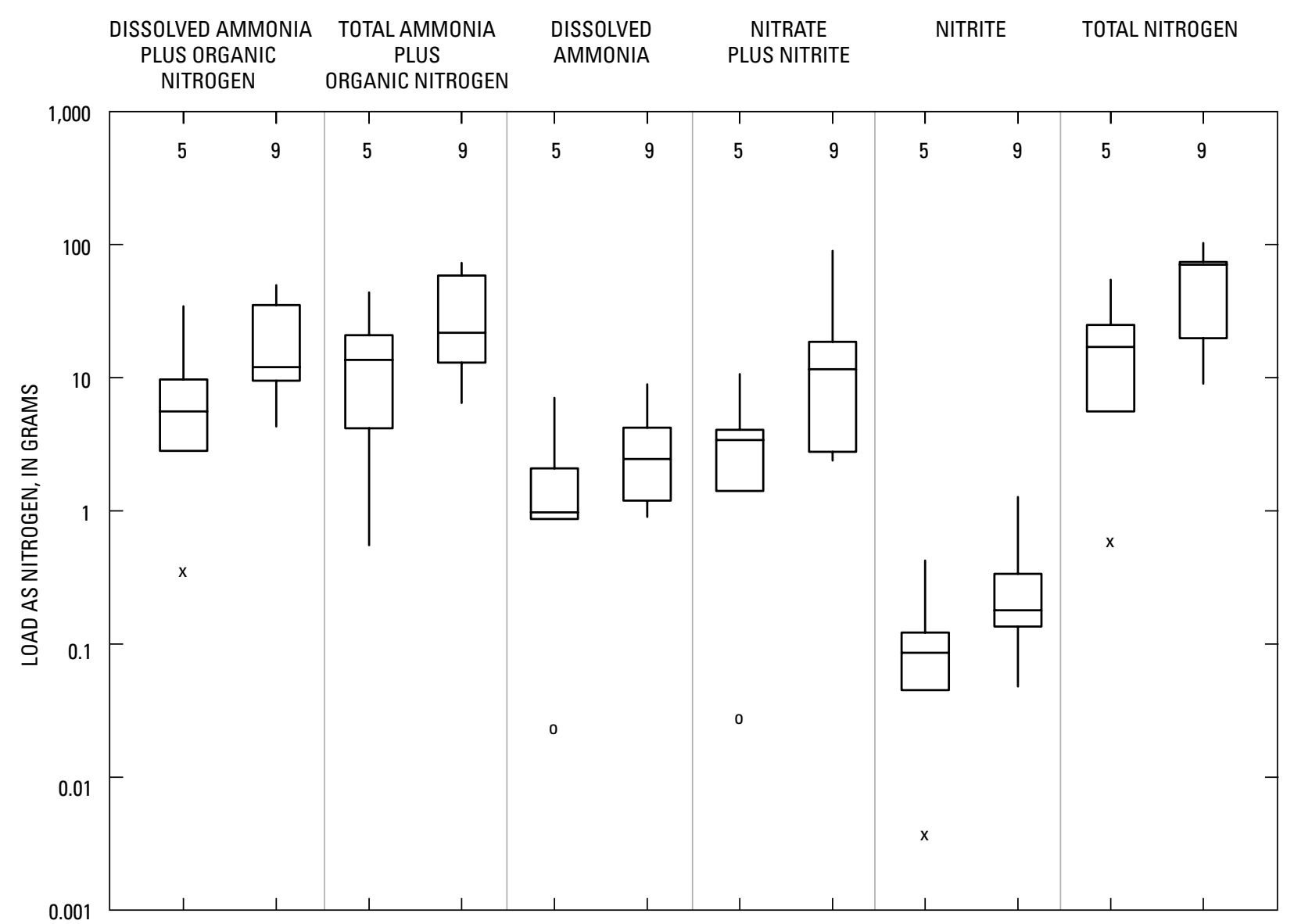

PRE-LID POST-LID PRE-LID POST-LID PRE-LID POST-LID PRE-LID POST-LID PRE-LID POST-LID PRE-LID POST-LID

\section{EXPLANATION}

$5 \quad$ Number of samples

\begin{tabular}{|l|l}
\hline & $\begin{array}{l}\text { Largest data value within } 1.5 \text { times the } \\
\text { interquartile range above the box }\end{array}$ \\
75 th percentile \\
\hline
\end{tabular}$\quad \begin{aligned} & \text { Median (50th percentile) } \\
& 25 \text { th percentile } \\
& \text { Smallest data value within } 1.5 \text { times the }\end{aligned}$ interquartile range below the box

$x \quad$ Data value 1.5 to 3.0 times the interquartile range below the box

$0 \quad$ Data value greater than 3.0 times the interquartile range above the box

Figure 30. Nitrogen analyte loads in runoff from storms that occurred before (Pre-LID, Aug. 2005-Feb. 2006) and after (Post-LID, Aug. 2006-Nov. 2007) installation of low-impact-development features along Silver Lake Avenue, Wilmington, MA. LID, low-impact development. 


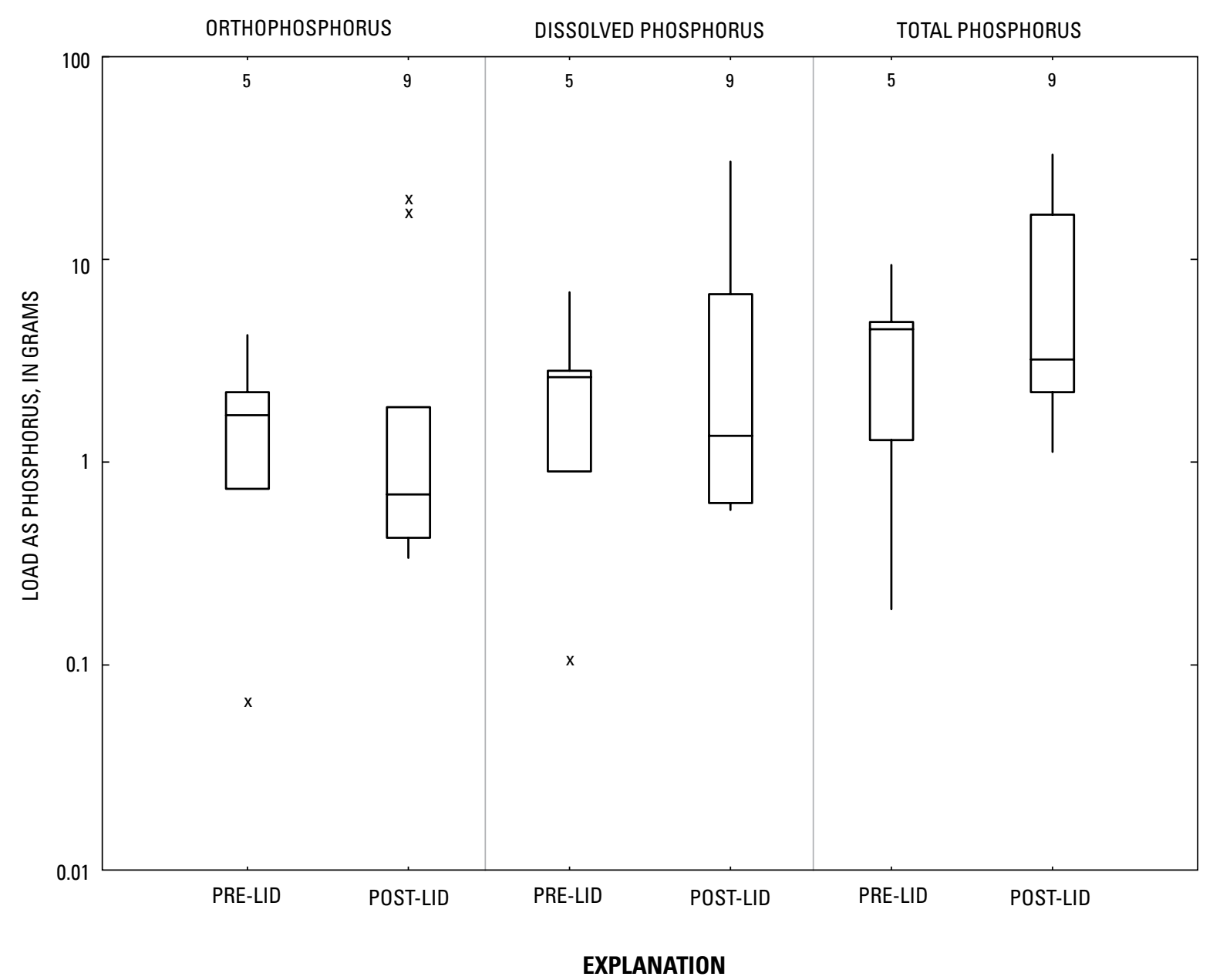

5 Number of samples

$x \quad$ Data value 1.5 to 3.0 times the interquartile range above the box

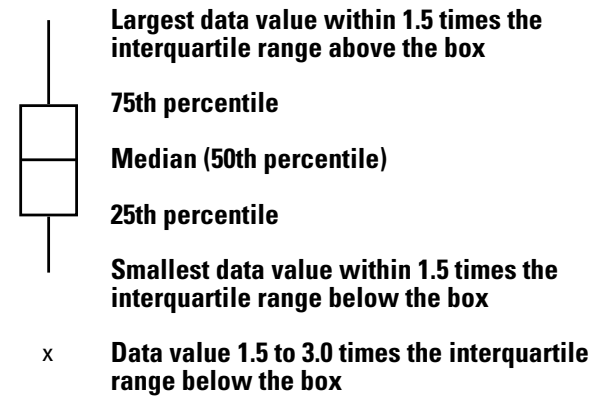

Figure 31. Phosphorus analyte loads in runoff from storms that occurred before (Pre-LID, Aug. 2005-Feb. 2006) and after (Post-LID, Aug. 2006-Nov. 2007) installation of low-impact-development features along Silver Lake Avenue, Wilmington, MA. LID, low-impact development. 


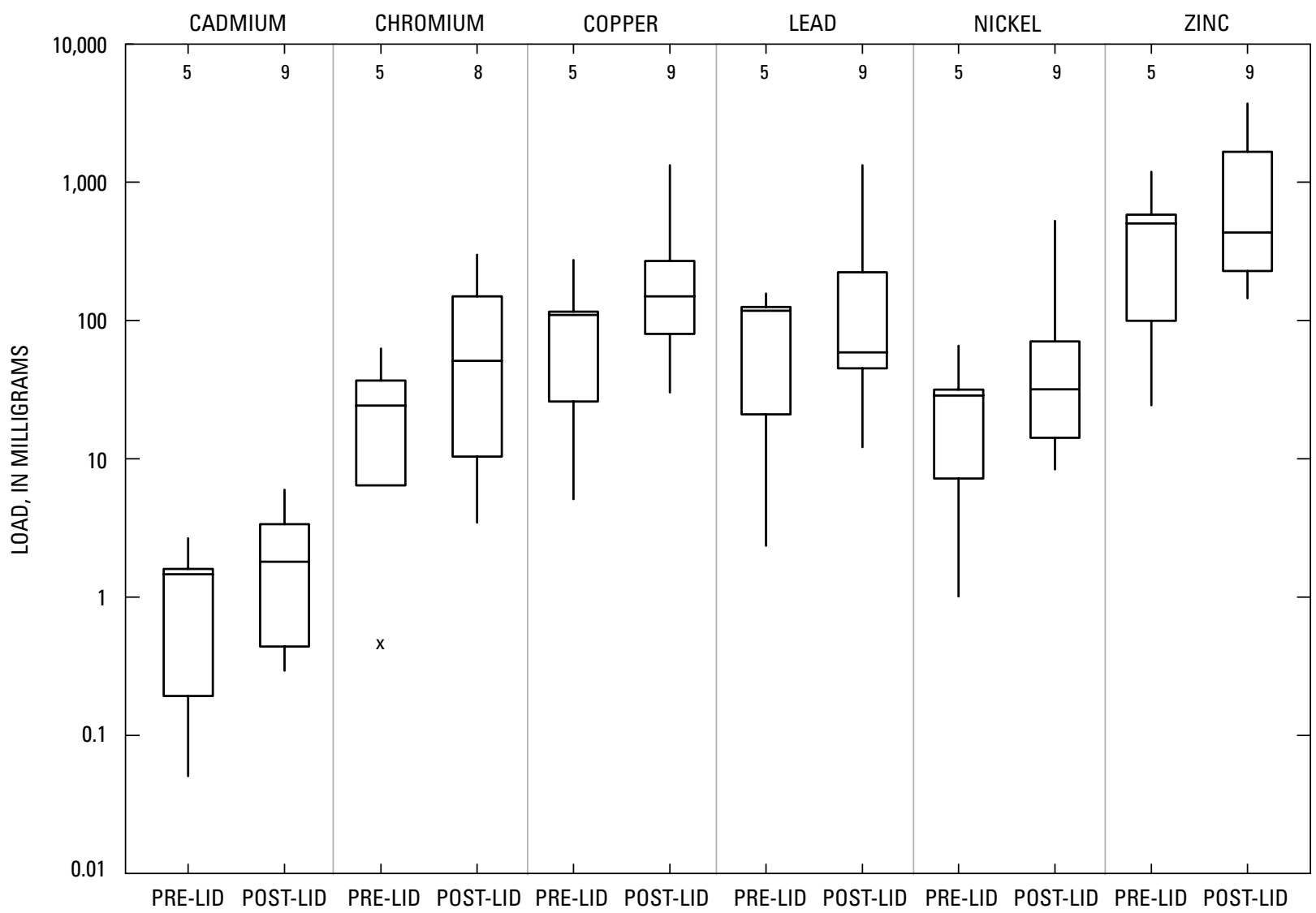

\section{EXPLANATION}

$5 \quad$ Number of samples

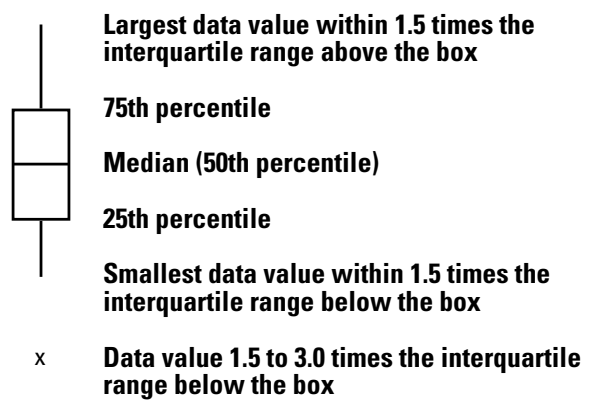

Figure 32. Cadmium, chromium, copper, lead, nickel, and zinc loads in runoff from storms that occurred before (Pre-LID, Aug. 2005-Feb. 2006) and after (Post-LID, Aug. 2006-Nov. 2007) installation of low-impact-development features along Silver Lake Avenue, Wilmington, MA. LID, low-impact development. 


\section{Green and Conventional Roofs and the Quantity and Quality of Stormwater Runoff}

Although green roofs have been used in Europe for some time, they are relatively new in North America, where they are, however, being applied to mitigate storm runoff (Berghage and others, 2007). A green roof generally consists of four parts or layers (fig. 33) - (1) an impervious material that serves to prevent roots and water from penetrating the building's roof at the bottom; (2) a sturdy drainage layer that allows water to pass rapidly to rooftop discharge points; (3) a lightweight, but highly absorbent, growing medium that provides the substrate for plants; and (4) drought-resistant vegetation. Green roofs are reportedly able to substantially reduce stormwater runoff volume and attenuate flow when compared to conventional roofs. The roof's plants and growing medium, through evapotranspiration and absorption, make runoff reduction and attenuation possible; the growing medium may also neutralize acidic precipitation through its inherent buffering capacity.

In Ipswich, MA, a 3,000- $\mathrm{ft}^{2}$ green roof was designed by K.J. Savoie Architecture and installed by Magco, Inc., a Tecta America company, on an existing building, the Whipple Annex, which was undergoing rehabilitation to serve as senior housing. Initial plantings on the green roof took place in September 2006; some additional material was added in 2007 to replace plants that had died. The plants included eight species of Sedum, Talinum calycinum (fameflower), and Allium schoenoprasum (chive). The starting date for water-quality sampling was delayed until late summer of 2007, after the vegetation became established (fig. 34). However, because of an extended rain-free period, the first samples were collected in October 2007. In order for the vegetation on the green roof to become established, fertilizers were applied during the first 2 years of development, which matched the period of this study. Detailed records of the specific types of fertilizers and their application schedules were not available for inclusion in this assessment. In general, the fertilizers were slow-release varieties. Six maintenance visits occurred during the first 2 years, three each summer. Fertilizer was applied at least once each summer.

Runoff water quantity and quality from this green roof were compared with runoff from a 5,340- $\mathrm{ft}^{2}$ section of the neighboring Ipswich Town Hall roof that has a conventional rubber-membrane roof (fig. 35) and with water quality in bulk precipitation (rain) falling on the conventional roof. Waterquality constituents examined in this study included nutrients (nitrogen and phosphorus), total metals $(\mathrm{Cd}, \mathrm{Cr}, \mathrm{Cu}, \mathrm{Pb}, \mathrm{Ni}$, and $\mathrm{Zn}$ ), and $\mathrm{TPH}$.

\section{Monitoring Approach}

Installation of the monitoring equipment took place in two stages. While the Whipple Annex was undergoing reconstruction and remodeling in autumn 2006, equipment was installed at the Ipswich Town Hall. The Town Hall had no outside drains from the roof so its indoor, $30-\mathrm{ft}$ vertical downspout was modified to incorporate a short, nearly horizontal section of PVC pipe fitted with v-notch weir with a bubble line used to record stage for conversion to flow data (fig. 36). The

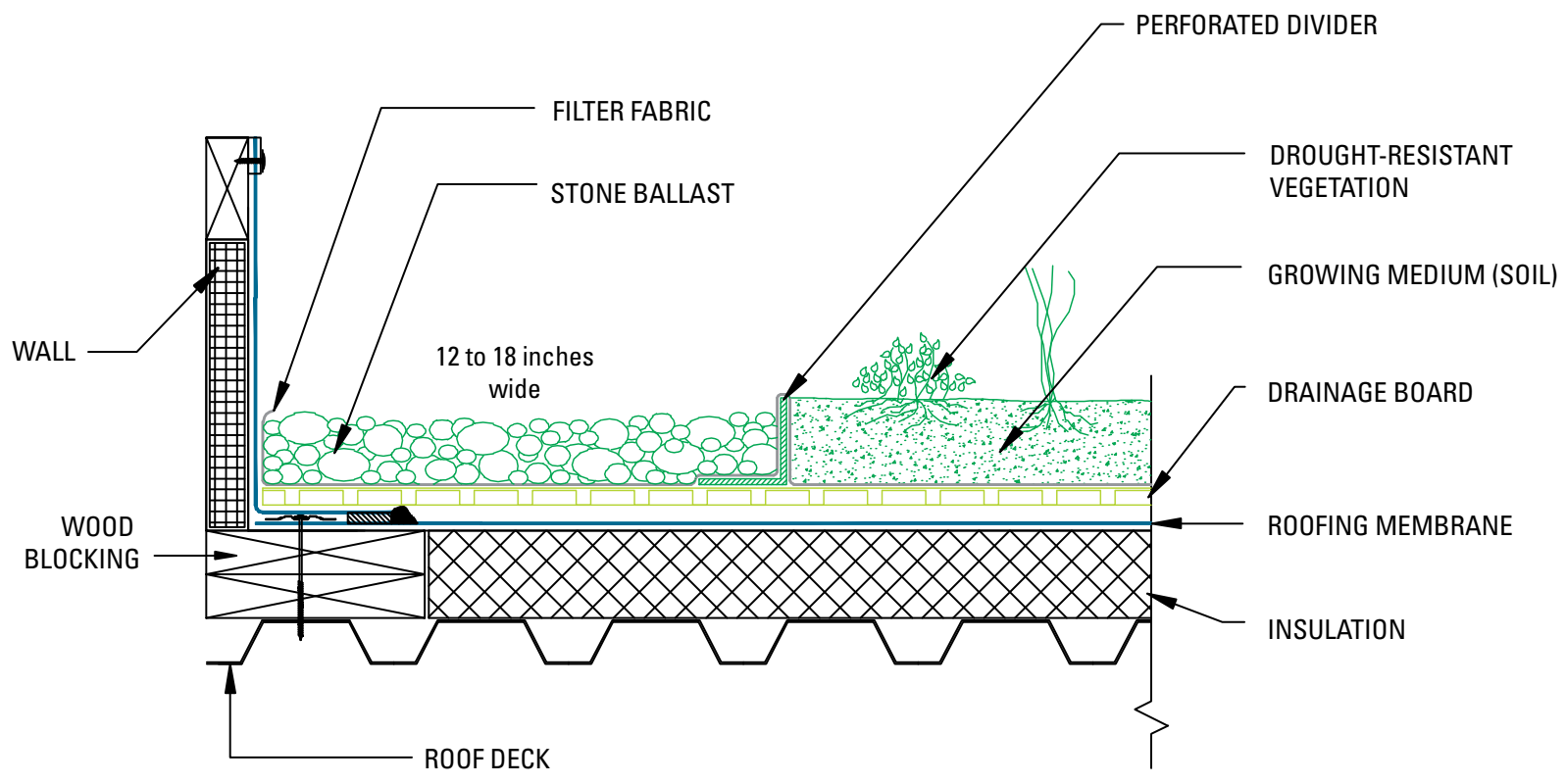

Figure 33. Structural features of a typical green roof. Schematic (modified) courtesy of Angela Durhman, Tecta America Corp. 
$\boldsymbol{A}$

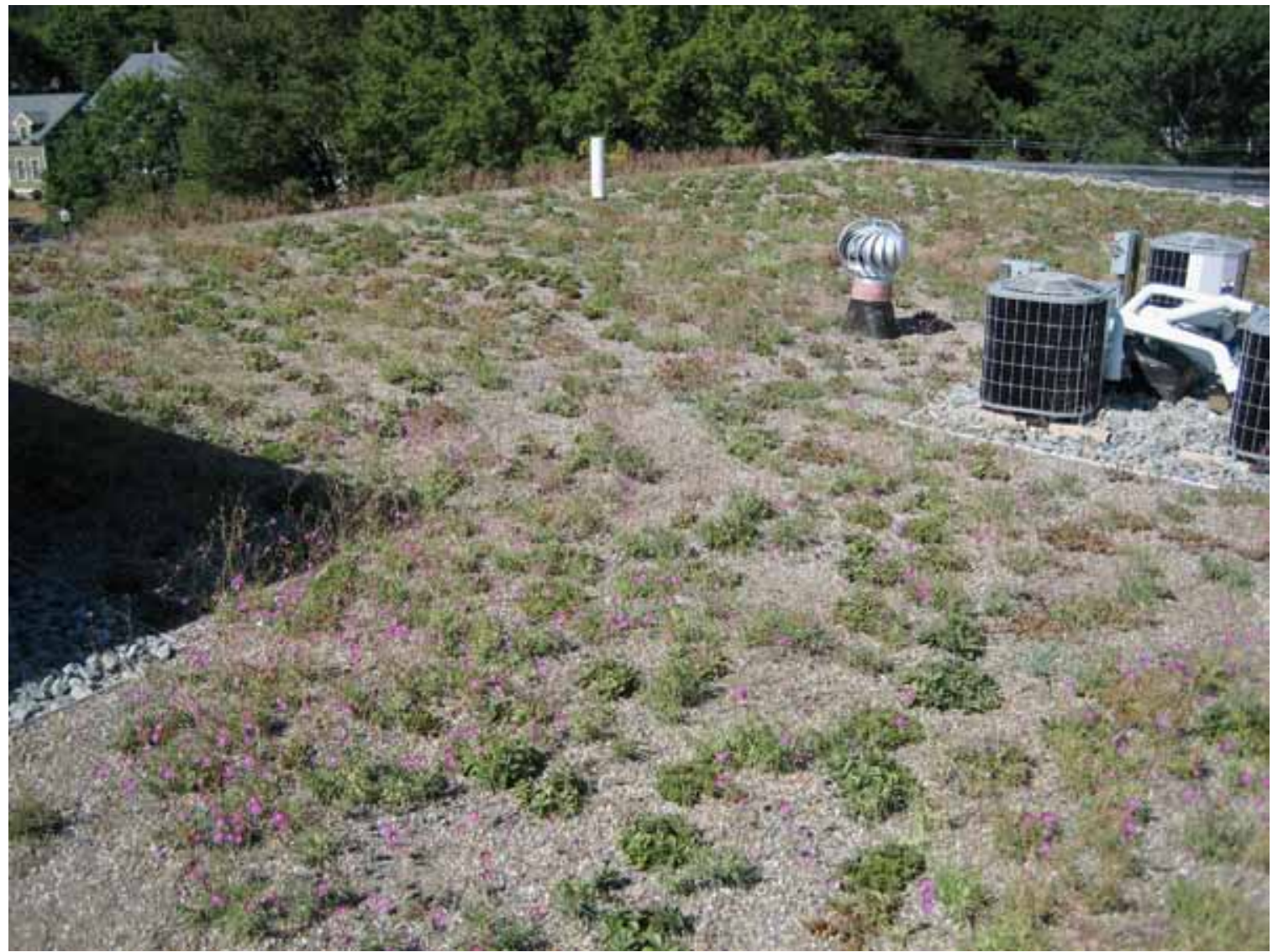

B

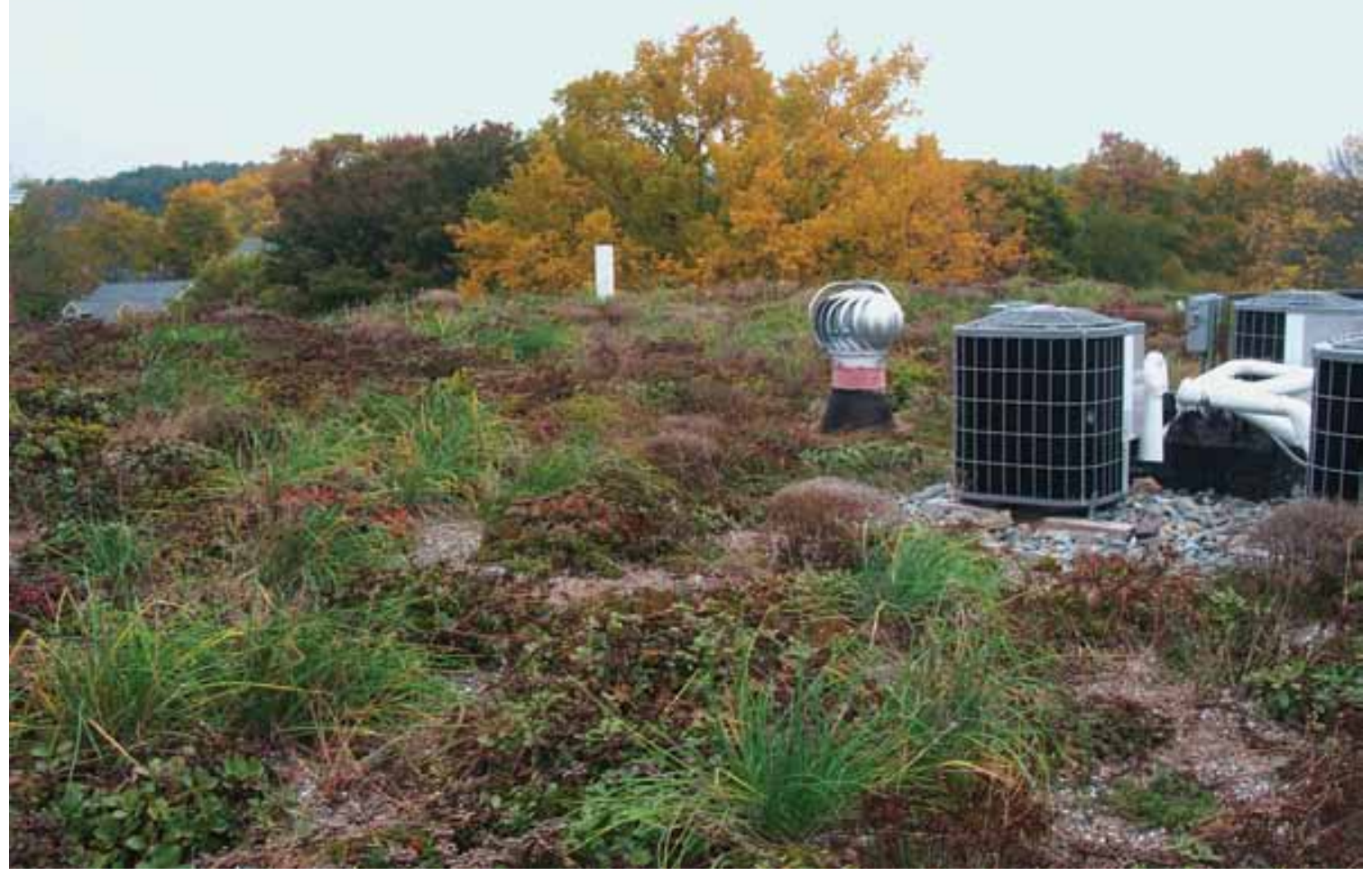

Figure 34. (A) Partially developed vegetation in summer 2007 and $(B)$ well-developed vegetation in autumn 2008 on the Whipple Annex green roof, Ipswich, MA. 


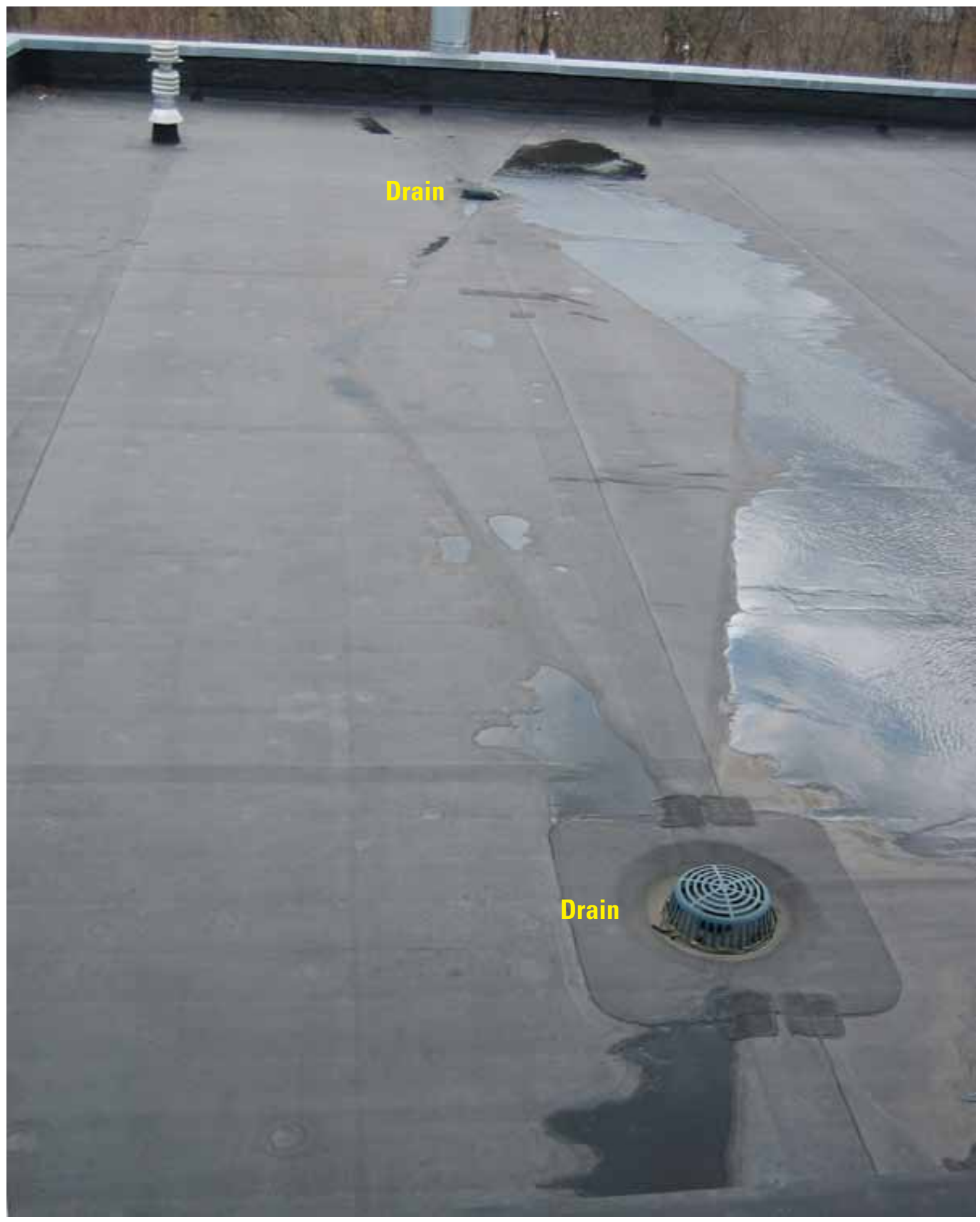

Figure 35. Rubber-membrane roof on the Ipswich, MA, Town Hall with drains leading into the building and to the runoff-monitoring and sampling system. 


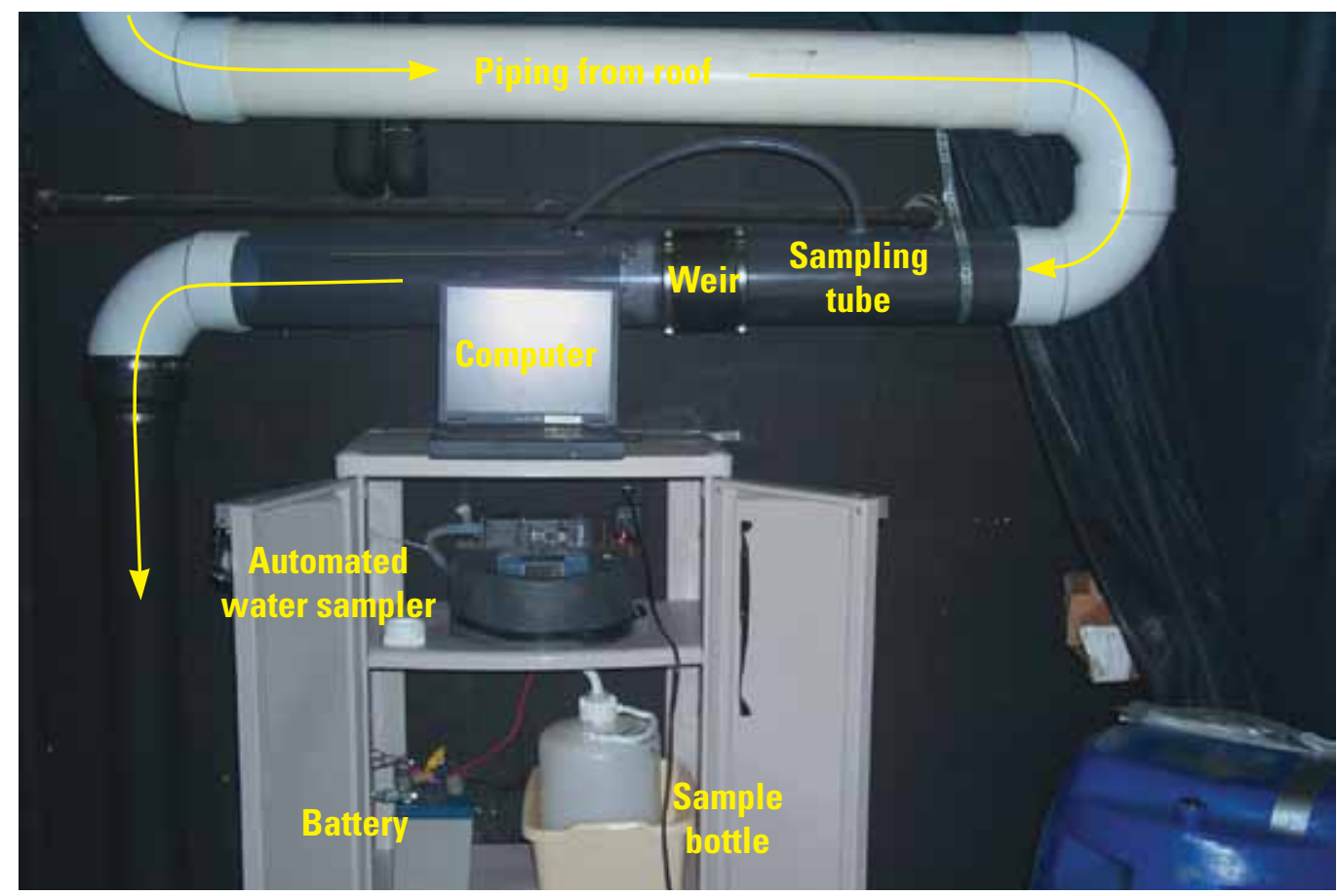

Figure 36. Roof-runoff flow-monitoring and sampling system in the Ipswich Town Hall, Ipswich, MA.

small "pool" behind the weir provided a water-quality-sample collection point.

All runoff from the slightly pitched, 3,000- $\mathrm{ft}^{2}$ Whipple Annex green roof drained to a 100 -ft-long gutter system attached to the eastern side of the building with three 4-in', vertical, aluminum downspouts. Drainage from these three aluminum outlets was routed to a central junction using 4-in.diameter polyvinyl chloride (PVC) pipe (fig. 37). Total green roof drainage then passed through a 10 -ft section of 6 -in. PVC pipe to another 4-in. PVC section containing a v-notch weir and eventually discharged through a 4-in. PVC level spreader designed to reduce potential erosion (fig. 37). Preparatory work at the Whipple Annex was completed in December 2006.

Both rooftop monitoring systems were equipped with the bubble line and datalogger to measure and record water level. The level-to-flow relation from the volumetric weir allowed calculation of discharge to support flow-proportional sampling with a Teledyne ISCO 6700 autosampler. The automated samplers were programmed to collect a maximum of 10 flow-proportional stormwater samples per storm based on forecasted precipitation amounts for each storm. Samples were collected in pre-cleaned 10-liter Teflon bags installed inside polyethylene containers. Containers were kept chilled throughout sampling period until they were retrieved. Site visits were made monthly or during storm sampling periods to check the condition of the weirs, the performance of instrumentation, and to prepare for water-quality sampling.

The Ipswich Town Hall stage and gymnasium complex was host to many different sporting events and social programs. Although precautions were taken to avoid it, the circuit breaker supplying power to the monitors and sampling equipment was occasionally shut down by other users of the complex, causing periodic power losses, until battery backup units were installed in autumn 2007.

The data record for the conventional-roof runoff began on January 31, 2007, and the Green roof drainage record began on June 21, 2007. Measurements were recorded at 15-min. intervals. Both roof runoff records end on November 17, 2008. Data losses occurred at the Whipple Annex site during the following periods: (1) July 8 to August 16, 2007, (2) October 6 to 23,2007 , (3) November 14, 2007, to February 4, 2008, and (4) July 10 to 23,2008 . The first two data gaps were attributed to power losses. The third data gap was the result of the datalogger software failure requiring repair by the manufacturer, and the fourth data loss was attributed to user error. Extremely high stage values during February and March 2008 coincided with icing. Icing was also observed in December 2007. Only one period of data loss at the Ipswich Town Hall site occurred during the period of record from July 8 to August 9, 2007.

A continuous precipitation gage and logger also were installed on the Ipswich Town Hall next to the runoff section of the roof. Continuous measurements of precipitation and roof runoff from both roof types began in June 2007 and were discontinued in October 2008. Three gaps in the Town Hall precipitation record occurred from (1) December 21, 2007, to February 2, 2008, (2) May 21 to 22, 2008, and (3) July 4 to 24, 2008. The first data gap was associated with a power loss in the heater funnel, the second resulted from a logger power loss, and the third was caused by a seed lodged in the precipitation gage's tipping bucket mechanism. 


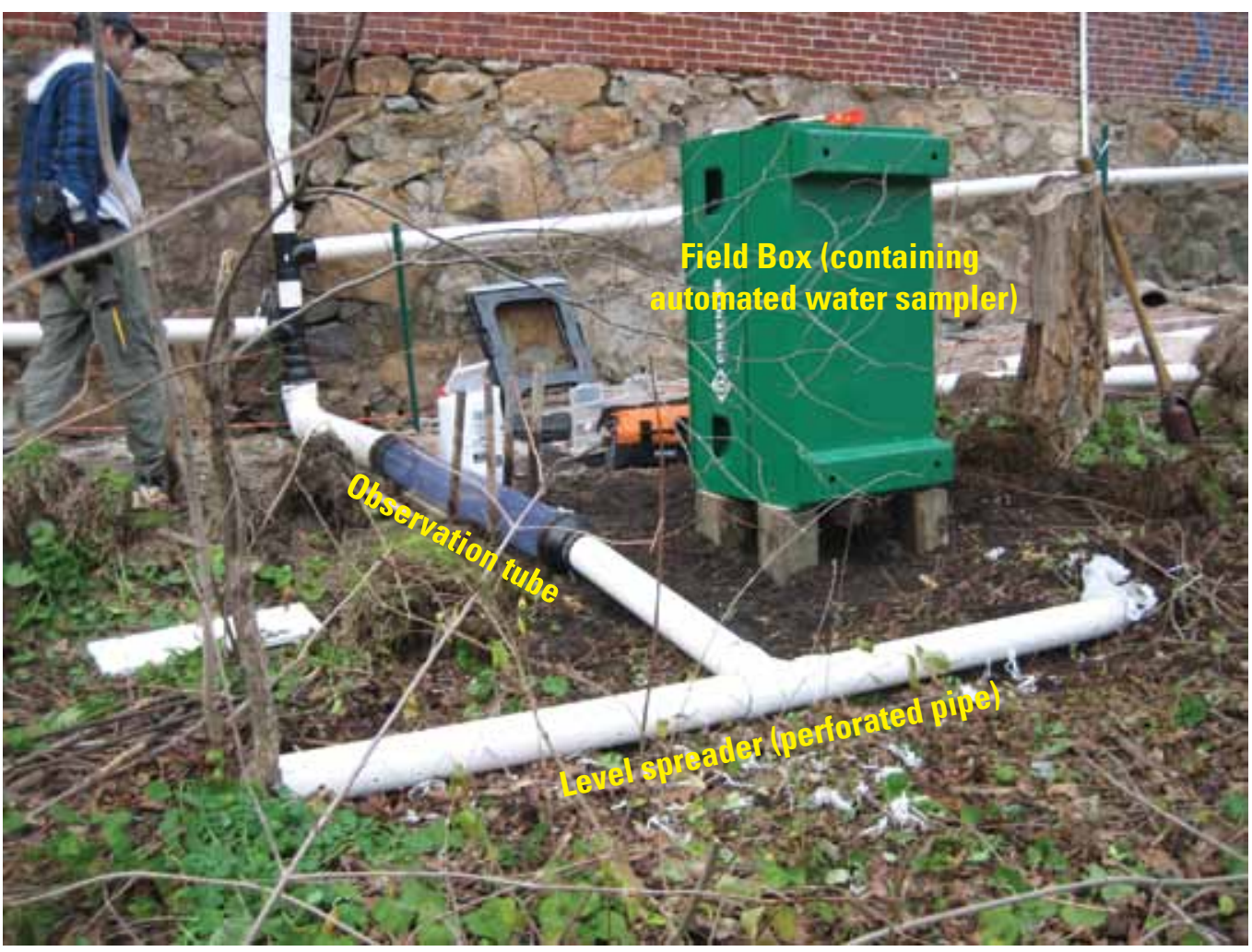

Figure 37. Roof-runoff flow-monitoring and sampling system during assembly at the Whipple Annex, Ipswich, MA. Three downspouts were joined to create a single monitoring location next to the green equipment box. A level spreader with multiple drainage holes ensured that runoff passing through the collection system would not cause erosion.

Gaps in the precipitation record were filled by substituting the precipitation record from the Ipswich Fire Department located approximately $0.38 \mathrm{mi}$ east of Town Hall. Ten flowproportional, storm-runoff composite samples were collected. After water-quality samples were retrieved, they were stored on ice at $4^{\circ} \mathrm{C}$ for transportation and processing. After processing, the samples were shipped to the USGS National Water Quality Laboratory (NWQL) for analysis. The only exception to this procedure was for TPH samples collected after January 1, 2008; starting at that time, all USGS samples were sent to a contract laboratory, TestAmerica Laboratories (TAL), Inc., in Arvada, CO, for analysis. TAL's reporting level for TPH was $5.0 \mathrm{mg} / \mathrm{L}$ (versus $2.0 \mathrm{mg} / \mathrm{L}$ for the NWQL). Background TPH concentrations in TAL laboratory blanks associated with environmental samples were unacceptably high, with one exception - the green roof environmental sample collected on July 23, 2008; therefore, the data are reported in the tables but are not interpreted.

In this study, small storms tended to generate inadequate volumes of runoff for water-quality samples and, subsequently, there were no chemical analyses for small storms. Thus, the study did not account for the reduction in constituent load that occurred by virtue of the absence of runoff from small storms.

\section{Comparison of Conventional and Green Roof Runoff Quantity and Quality}

The growing medium installed on the green roof is capable of absorbing about 1 in. of precipitation (Angela Durhman, Green Roof Manager, Tecta America Corp., oral commun., 2008). The actual amount absorbed for a given storm will depend on several factors, including antecedent conditions, total rainfall and its duration, and temperature. When considering roof runoff, the concept of storm intensity (rainfall divided by duration) may not be as important a factor as it is in natural landscape drainage. On a roof, all precipitation drains downward; it cannot become diffuse surface runoff when the intensity exceeds the infiltration capacity of the soil.

Runoff data were collected on a more-or-less continuous basis throughout the study period. Storms targeted for waterquality sampling were expected to produce runoff from the green roof to provide sample volumes sufficient for analyses of all target analytes because the absorption and storage capacity of the green roof soil medium during minor rainfall events with dry antecedent conditions should result in little or no runoff. Storms that were anticipated to produce runoff from the green roof did not always produce adequate volumes of water for analysis of the complete suite of nutrients, metals, 
and TPH, resulting in additional storm sampling or incomplete suites of analytes for some storms.

\section{Roof-Runoff Quantity}

In all, roof runoff from 118 storms was examined. Storms producing less than 0.04 in. of rain were not included because they yielded minimal runoff that could not be measured with sufficient accuracy. Storms during freezing conditions and affected by snow melt also were not considered in this analysis. Storms that produced runoff from the rubber-membrane roof that was not within \pm 15 percent of the expected volume determined from the rainfall volume also were rejected because of the measurement error in the runoff or precipitation, or both. Of the remaining 70 storms, those with runoff volumes within 15 percent of the expected runoff volume from the rubber-membrane roof were used in these analyses, providing 30 storms for comparisons between the rubber-membrane and green roofs. Data from 40 other storms were of sufficient quality for use in examining runoff characteristics of the green roof alone.

The ability of a vegetated green roof to retain precipitation was the focus of this part of the study. Several factors can affect the volume retained and the attenuation of runoff; the amount and duration of precipitation and antecedent dry conditions are the most obvious. The effects of these factors were examined for five individual storms of varying precipitation totals, duration, and antecedent conditions. Storm runoff from the roofs was determined from the start of precipitation until runoff stopped or until 6 hours after precipitation ended, if runoff from the green roof had not stopped. In order to compare storm runoff from the rubber-membrane and green roofs and evaluate retention by the green roof, data are presented in pairs of graphs (figs. 38 to 42). The first graph of each pair depicts standard hydrographs for runoff from the two roofs and a hyetograph of the rainfall. The second graph presents double-mass curves for the same data. The double-mass curves represent the cumulative-percentage data over time for total precipitation and for total calculated, or potential, runoff that fell on each roof based on measured precipitation; that is, their differences are normalized by percentage of roof area. In theory, the runoff from the rubber-membrane roof would equal the total precipitation, but measurement error may cause slight deviations from expected values. Green roof runoff is normalized to the amount that was expected to fall on it, given its having about 45 percent less area than the rubber-membrane roof. The final percentage of runoff is the complement of the percentage retained.

Runoff from the rubber-membrane roof responds directly to the rate of precipitation and does not vary by antecedent conditions. The runoff response to precipitation on the green roof varies by the size of the storm and antecedent conditions, as exemplified in the five examples that follow.

The first storm under consideration here occurred on September 27, 2007. After an antecedent dry period of nearly 300 hours, a storm of 1-hour duration and totaling 0.13 in. of precipitation resulted in a maximum runoff of about $0.02 \mathrm{ft}^{3}$ from the rubber-membrane roof (fig. 38A). Runoff from the green roof generated by this storm started about 0.5 hours later, producing a maximum discharge of less than $0.001 \mathrm{ft}^{3}$. A total of $61 \mathrm{ft}^{3}$ ran off the rubber-membrane roof, and about $3.3 \mathrm{ft}^{3}$ ran off the green roof. The percentage of the total cumulative runoff from the rubber-membrane roof slightly exceeded the total cumulative precipitation because of some minor measurement errors, likely because the rate of flow exceeded the accuracy limits of the instruments or because of hysteresis effects, whereas the mass of runoff from the green roof was less than 10 percent of the total rainfall (fig. 38B).

Storms (figs. 39 and 40) on September 9, 2007, and October 26, 2008, were of moderate size -0.61 and 0.78 in. of total precipitation, and 16.75 and 7.25 hours in duration. The storms differed considerably in their antecedent conditions; the times since the previous precipitation were about 532 and 87 hours for the September 29, 2007, and October 26, 2008 , storms, respectively. Both storms had two precipitation episodes reflected in the hydrographs and double-mass curves for each roof. Although the October 26 storm's relatively short duration resulted in an average intensity about 3 times greater than that of the September 9 storm $(0.108$ and $0.036 \mathrm{in} / \mathrm{h}$, respectively), differences in the green roof runoff responses are attributed mostly to antecedent conditions. The time since the last rainfall was about 6 times longer for the September 9 storm than for the October 26 storm, which resulted in less available storage leading into the October 26 storm. Runoff from the green roof was delayed about 1 hour from the start of precipitation from both storms (figs. 39A, 40A). Runoff from the green roof's first episode of precipitation was more pronounced for the October 26 storm than for the September 9 storm with respect to the amount of precipitation from each storm and during each part of the storm, a reflection of the greater intensity of early part of the October 26 storm. The September 9 storm produced a total of $273 \mathrm{ft}^{3}$ of runoff from the rubber-membrane roof and about $13 \mathrm{ft}^{3}$ of runoff from the green roof; overall, the green roof retained about 85 percent of the precipitation that fell on it (fig. 39B). The October 26 storm produced $357 \mathrm{ft}^{3}$ of runoff from the rubbermembrane roof and about $55 \mathrm{ft}^{3}$ from the green roof; overall, the green roof retained about 70 percent of the total precipitation (fig. 40B).

Two of the largest storms during the study period began on September 11, 2007, and September 26, 2008. The September 11, 2007, storm (fig. 41) left 1.27 in. of precipitation and lasted 7.5 hours; the storm was preceded by two smaller storms of 0.11 and $0.61 \mathrm{in}$. that occurred about 10 and 32 hours earlier, respectively. The initial, light precipitation on September 11 did not generate runoff, but runoff increased rapidly about 2 hours into the storm because the available storage was likely filled from the recent preceding storms and initial rainfall from this storm. As a result of the depleted storage, the green roof was able to retain only about 20 percent of the total storm precipitation volume (fig. 41B). 
A 0.13 -inch storm, 298.5-hour antec edent dry period, 1.00-hour duration, and 0.13-inch-per-hour intensity

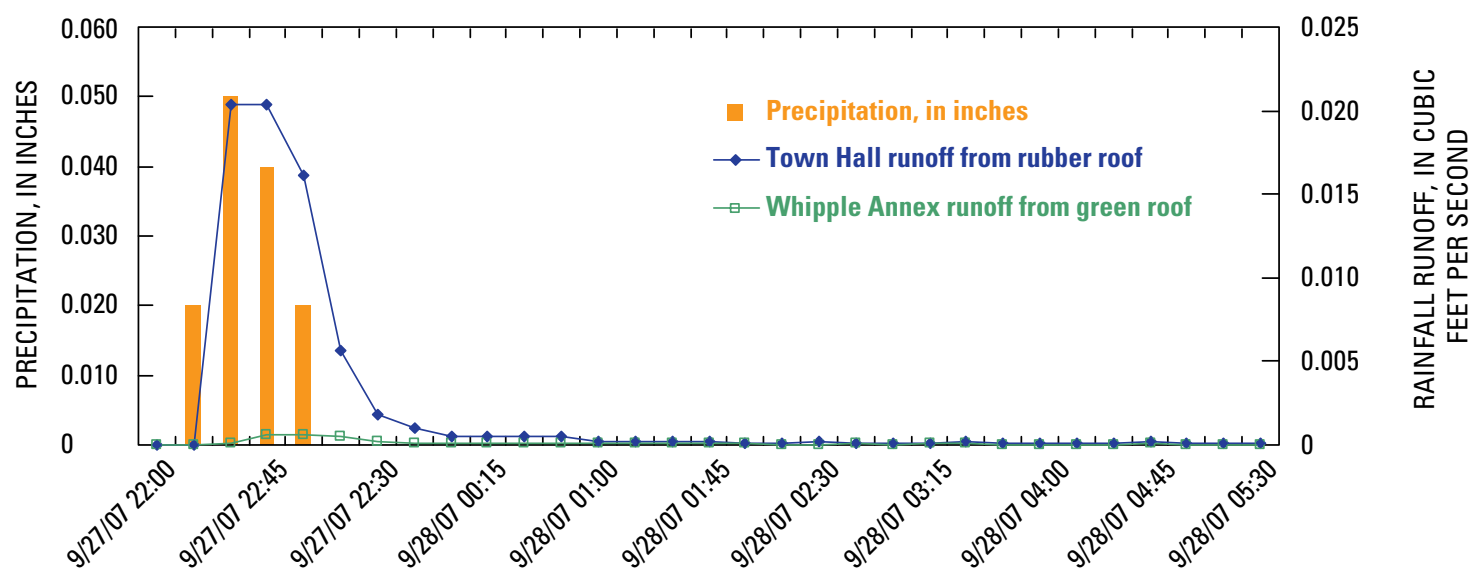

B 0.13-inch storm, 298.5-hour antecedent dry period, 1.00-hour duration, and 0.13-inch-per-hour intensity

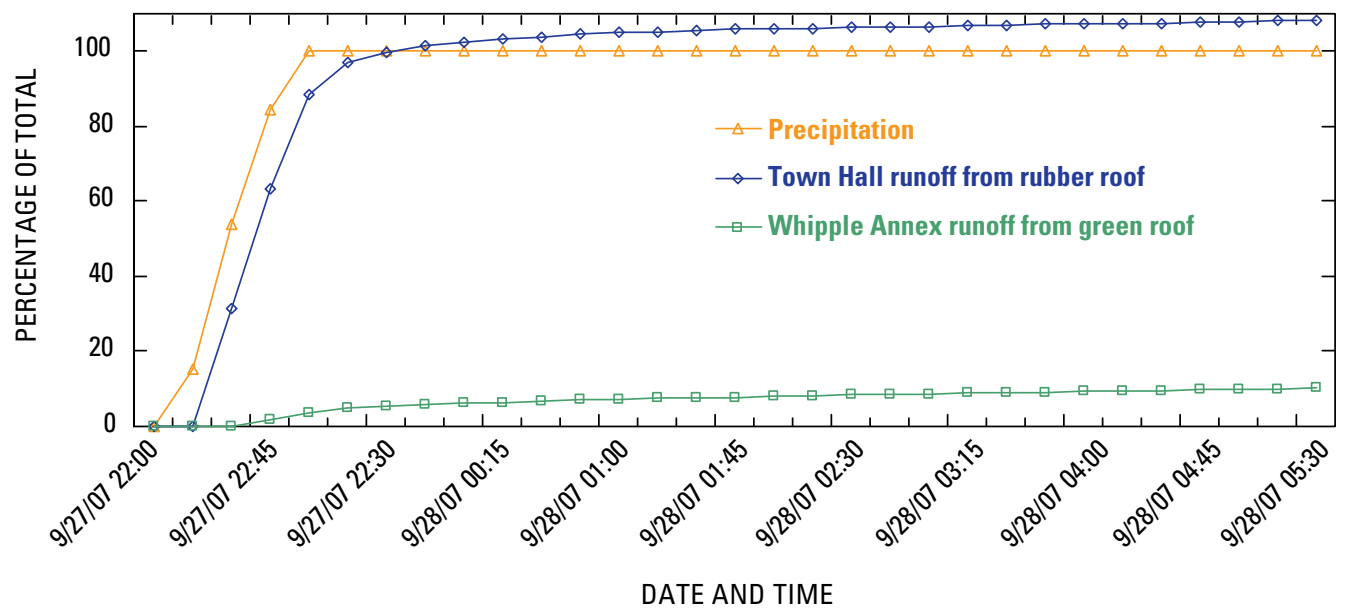

Figure 38. (A) Precipitation on and runoff from conventional rubber and green roofs in Ipswich, MA, for the storm of September 27, 2007, and $(B)$ cumulative percentages of total precipitation and total runoff from the roofs for the same storm. 


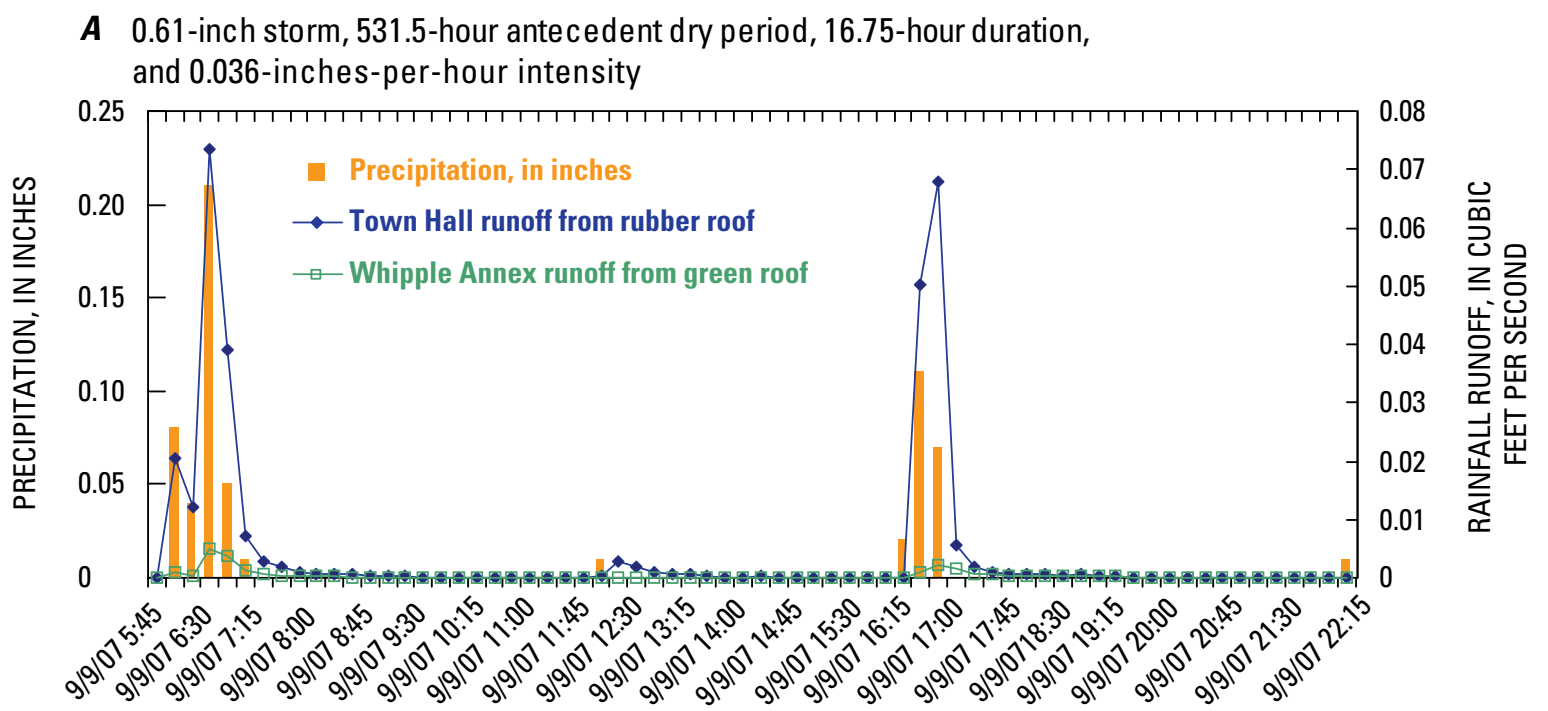

B 0.61 -inch storm, 531.5-hour antecedent dry period, 16.75-hour duration, and 0.036 -inches-per-hour intensity

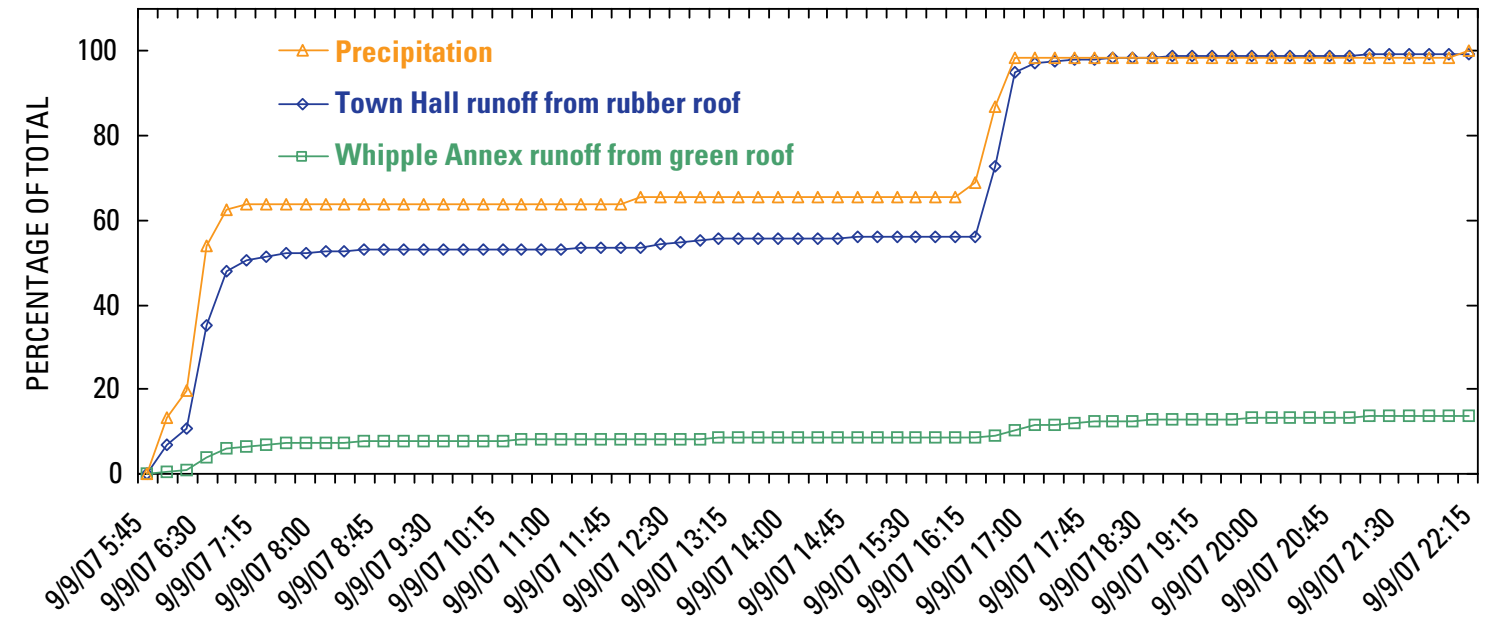

\section{DATE AND TIME}

Figure 39. (A) Precipitation on and runoff from conventional rubber and green roofs in Ipswich, MA, for the storm of September 9,2007 , and $(B)$ cumulative percentages of total precipitation and total runoff from the roofs for the same storm. 
A 0.78 -inch storm, 87-hour antecedent dry period, 7.25 -hour duration, and 0.108 -inch-per-hour intensity

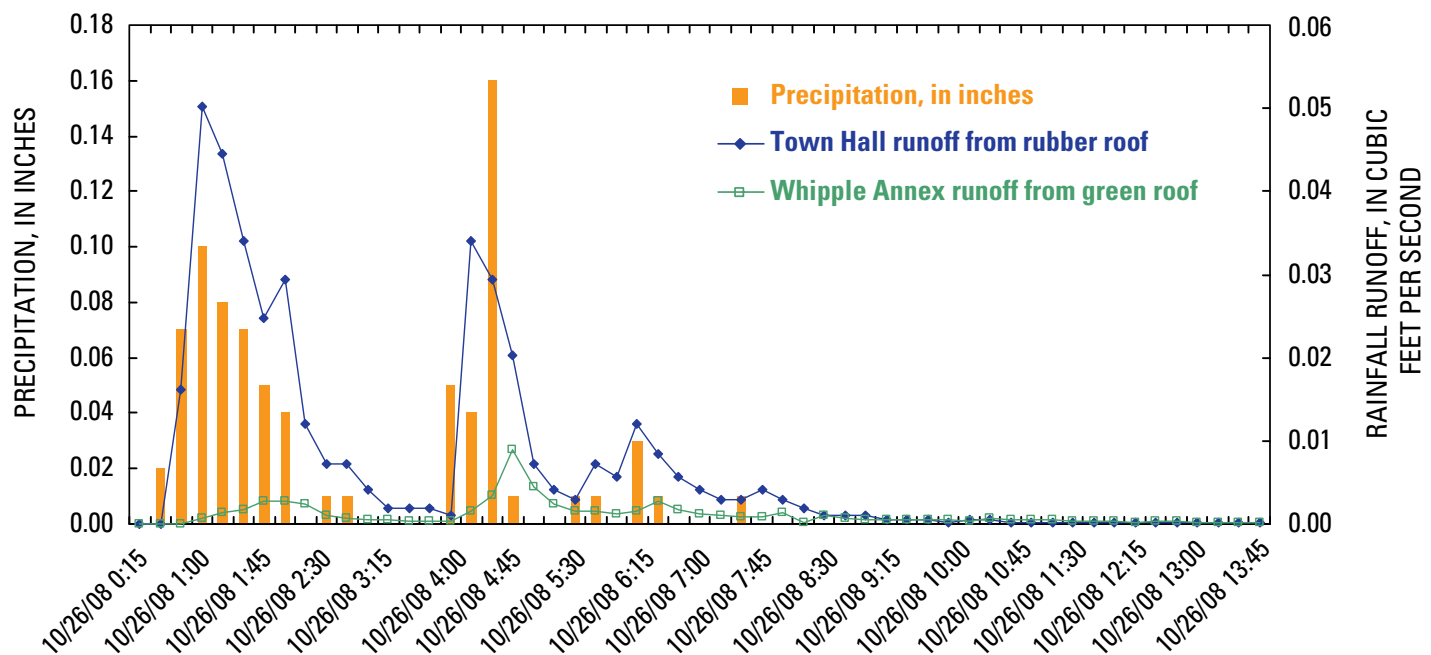

B 0.78 -inch storm, 87-hour antecedent dry period, 7.25-hour duration, and 0.108-inch-per-hour intensity

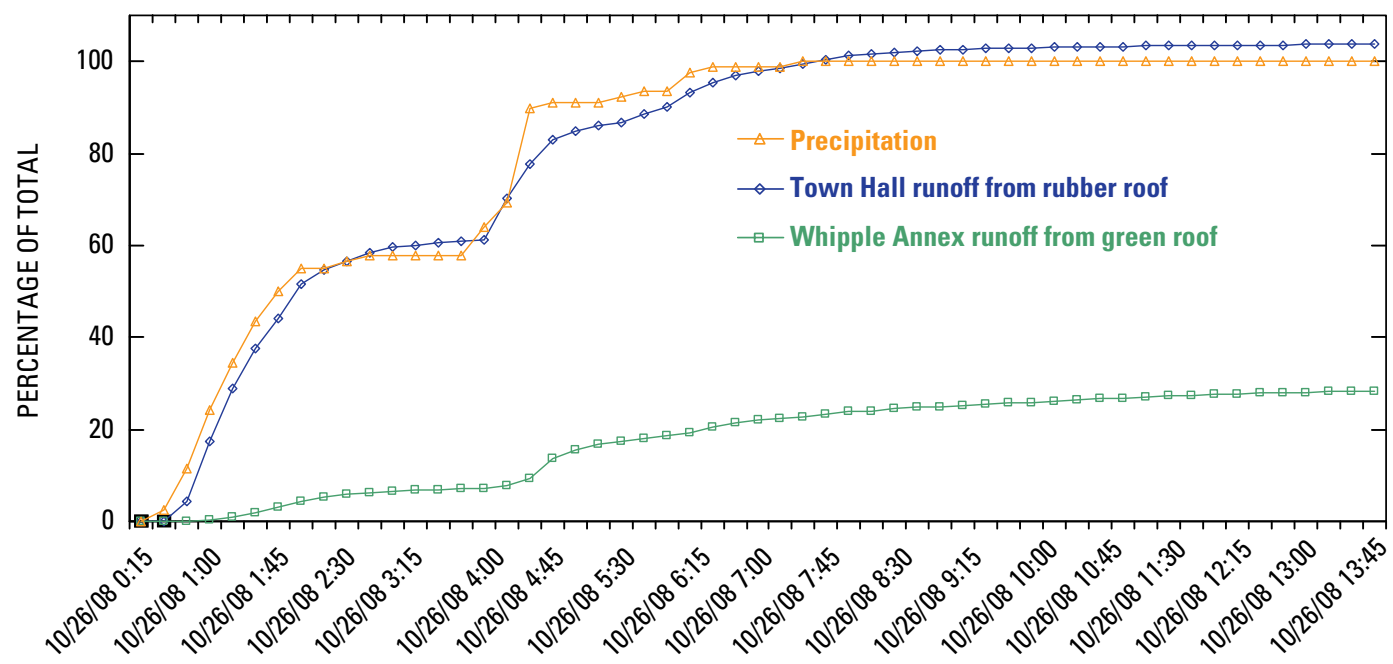

DATE AND TIME

Figure 40. (A) Precipitation on and runoff from conventional rubber and green roofs in Ipswich, MA, for the storm of 0 ctober 26,2008 , and $(B)$ cumulative percentages of total precipitation and total runoff from the roofs for the same storm. 
A 1.27-inch storm, antecedent dry period 9.75 hours since 0.11 -inch event and 32.25 hours since 0.61-inch event, 7.5-hour duration and 0.169-inch-per-hour intensity

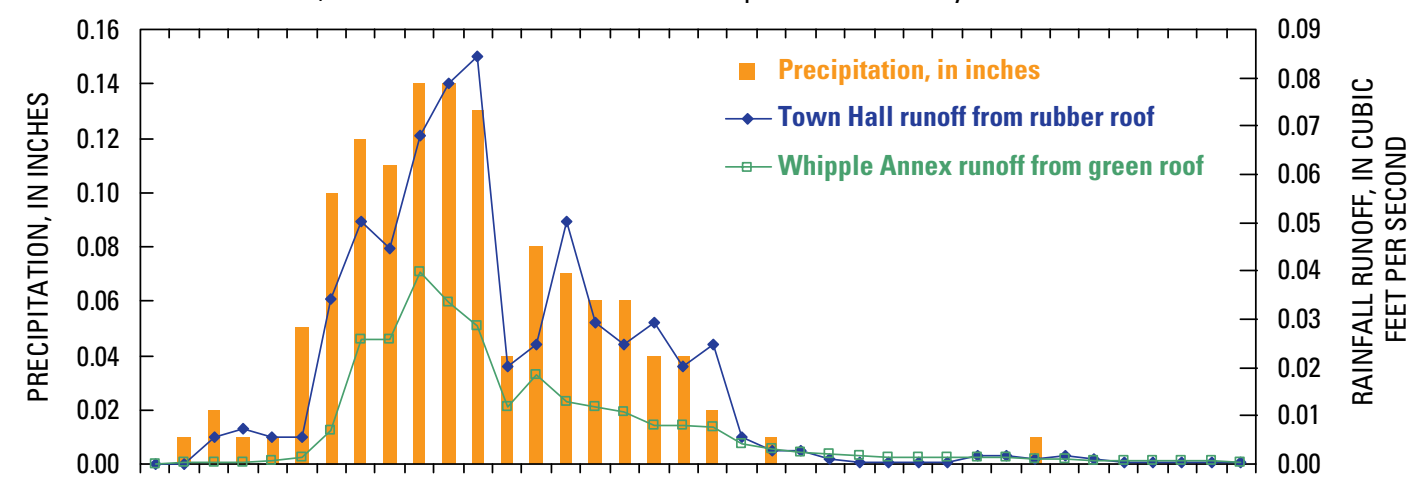

B 1.27-inch storm, antecedent dry period 9.75 hours since 0.11 -inch event and 32.25 hours since 0.61 inch event, 7.5-hour duration and 0.169-inch-per-hour intensity

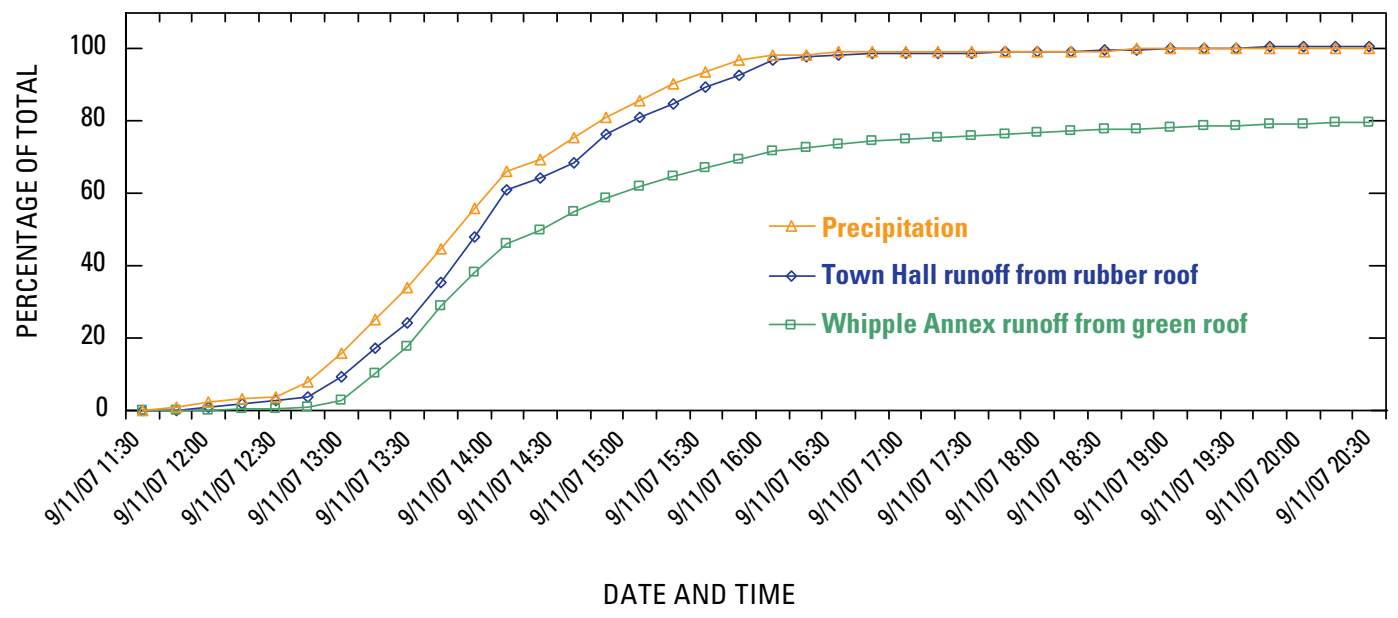

Figure 41. (A) Precipitation on and runoff from conventional rubber and green roofs in Ipswich, MA, for the storm of September 11, 2007, and $(B)$ cumulative percentages of total precipitation and total runoff from the roofs for the same storm. 
A 2.79-inch storm, 105-hour antecedent dry period, 17.5-hour duration, and 0.17-inch-per-hour intensity

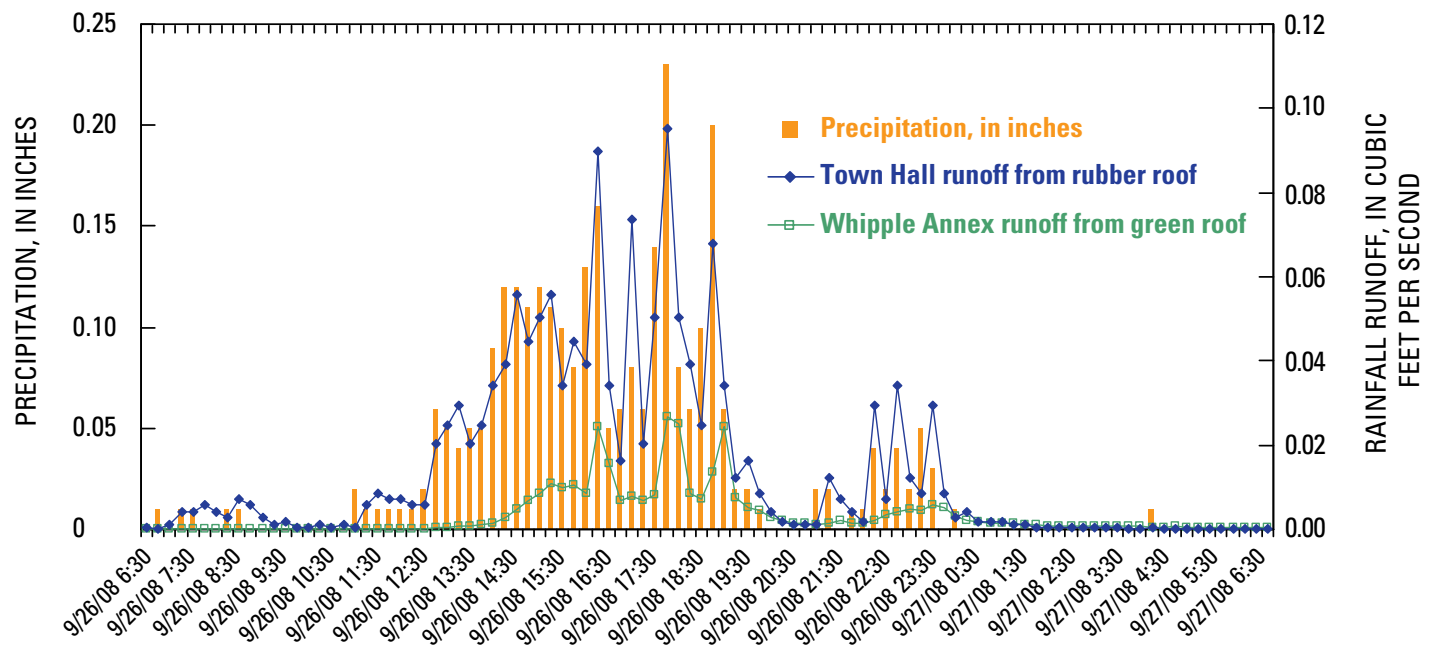

B 2.79-inch storm, 105-hour antecedent dry period, 17.5-hour duration, and 0.17-inch-per-hour intensity

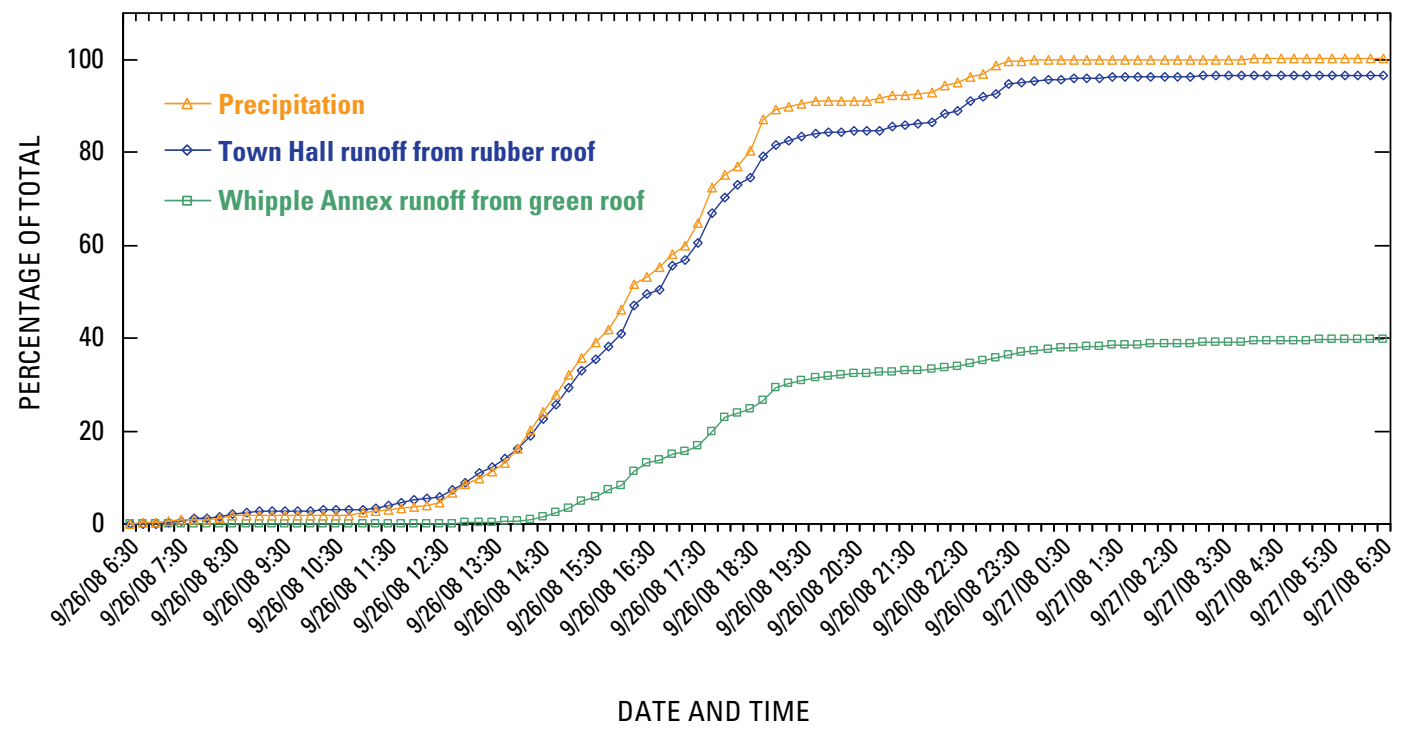

Figure 42. (A) Precipitation on and runoff from conventional rubber and green roofs in Ipswich, MA, for the storm of September 26, 2008, and $(B)$ cumulative percentages of total precipitation and total runoff from the roofs for the same storm. 
The September 26, 2008, storm was about twice as large in terms of total precipitation (2.97 in.) as the September 11, 2007, storm. The September 26, 2008, storm was characterized by 17.5 hours of duration and intensity of about $0.17 \mathrm{in} / \mathrm{h}$ (fig. 42), about the same intensity as the September 11, 2007, storm. The antecedent dry period of the September 26, 2008, storm (105 hours) was distinctly longer than that of the September 11, 2007, storm, producing a much different runoff response from the green roof. The initial rain on September 26, 2008, did not produce a measurable runoff response from the green roof for about 4 hours; whereas, the initial precipitation on September 11, 2007, which was considerably less than the precipitation on September 26, produced a more marked response about 1.5 hours after the start of the storm. Even though the September 26, 2008, storm had about 2.5 times the amount of precipitation, the green roof retained about 60 percent of the total precipitation (fig. 42B), or about 20 percent more than the September 11, 2007, storm.

The five example storms indicate how general characteristics yield differing runoff responses from the green roof over a wide range of storms (table 6). Clearly, total precipitation and antecedent dry period play the most important roles in water retention on the green roof. There is a finite amount of precipitation that the soil medium can retain, and this amount is affected by the amount of water that may remain from previous storms, which is a function of the time since and amount of previous precipitation. Retention is also a function of potential evapotranspiration during the antecedent dry period that changes seasonally. Thus, the green roof retained about 70 to 90 percent of the precipitation from the September 27, 2007, September 9, 2007, and October 26, 2008, storms. About 60 percent of the precipitation in the largest storm (September 26,2008 ) was retained by the green roof, but in a storm with less than half that precipitation (September 11, 2007), the green roof retained only about 20 percent of the precipitation because of wet antecedent conditions.

A broader view of the green roof performance was obtained by comparing general storm characteristics to runoff volume from the 70 storms used for analysis. The percentage of runoff retained is directly related to the available volume that can be stored in the green roof growing medium (and its associated vegetation). The percentage of precipitation retained in relation to total precipitation (fig. 43) varies from nearly zero to 100 percent for storms less than 1 in., which is the green roof's design capacity. Oddly, for a storm with nearly $2.0 \mathrm{in}$. of precipitation, with an antecedent dry period of about 376 hours, nearly all the precipitation was retained by the green roof, indicating that the roof may have nearly twice the storage capacity of the design. Other possible explanations are precipitation or runoff measurement errors, or both. For other large storms, the roof did not exhibit similar runoff retention, which is consistent with the green roof design capacity.

In general, the green roof retained less than 50 percent of the precipitation from relatively few storms (21 of 70); most of those storms had short antecedent dry periods (less than 70 hours since last precipitation; fig. 44). For the most part, more than 50 percent of the rainfall from storms of less than $0.10 \mathrm{in}$. of precipitation was retained by the green roof, regardless of the antecedent dry period. Nearly half (34) of the storms fell in the category of 0.10 to 0.49 in. of precipitation; the green roof retained more than 50 percent of the precipitation in all but nine of these storms. Antecedent dry periods and total storm precipitation do not explain all of the variability in retention. The discrepancy indicates that neither the precipitation volume nor the potential evapotranspiration that largely control the available storage during the antecedent period are fully accounted for.

\section{Roof-Runoff Quality}

Unlike the examination of stormwater-runoff water quality at Silver Lake Avenue, the major considerations for roof-runoff water quality are not differences in constituent loads between a green roof and a conventional roof, but in the ability of a green roof to retain the chemical constituents of precipitation. Runoff water quality from the green roof was characterized by higher median concentrations of several nutrient constituents (total organic nitrogen, total phosphorus, and dissolved phosphorus) and metals $(\mathrm{Cd}$ and $\mathrm{Cu})$ than were detected in either runoff from the rubber-membrane roof or from bulk precipitation (figs. 45,46 ); the bulk precipitation samples generally had the lowest concentrations of the nutrients and metal analytes. Leaching of phosphorus and nitrogen from green roofs has been reported elsewhere (Oberndorfer and others, 2007; Dietz, 2007). More germane to this study than nutrient leaching is the documentation that the green roof vegetation was fertilized at least once each summer, although complete records of the summer fertilization schedule were not kept. While it may be possible to evaluate the composition of the fertilizers used and even the recommended application rate, the actual quantities of fertilizer applied cannot be determined. Thus, any water-quality results reported for this part of the study refer to the differences among the rubber-membrane roof, bulk precipitation, and the fertilized green roof.

The chemical composition of the growing medium on the green roof is likely to have affected the chemical composition of runoff. The green roof growing medium is composed of crushed clay ( 70 to 80 percent by volume) and 20 to 30 percent organic matter (Angela Durhman, Green Roof Manager, Tecta America Corp., written commun., 2008). The chemical composition is not known, but this growing medium and the plants themselves compose sources of nutrients required for growth. In addition to the standard blank and replicate samples, a sample of the growing medium was collected and brought to the laboratory at the USGS Massachusetts-Rhode Island Water Science Center; $18.01 \mathrm{~g}$ of material were placed in a beaker containing $3 \mathrm{~L}$ of deionized water for 13 days. Samples of this water were collected and shipped to the NWQL or TAL for analysis of nutrients, metals, and TPH. The analyses of these samples reveal the growing medium to be a potential source of nutrients, phosphorus in particular, and 
Table 6. Characteristics of five selected storms and runoff from the rubber roof on Town Hall and from the green roof on Whipple Annex, Ipswich, MA, 2007-08.

[in/hr, inches per hour; $>$, greater than]

\begin{tabular}{llccccc}
\hline \multicolumn{1}{c}{ Storm date } & $\begin{array}{c}\text { Total } \\
\text { precipitation } \\
\text { (inches) }\end{array}$ & $\begin{array}{c}\text { Antecedent } \\
\text { dry period } \\
\text { (hours) }\end{array}$ & $\begin{array}{c}\text { Storm } \\
\text { intensity } \\
\text { (in/hr) }\end{array}$ & $\begin{array}{c}\text { Percent } \\
\text { retention }\end{array}$ & $\begin{array}{c}\text { Town Hall } \\
\text { runoff } \\
\text { (cubic feet) }\end{array}$ & $\begin{array}{c}\text { Whipple Annex } \\
\text { runoff } \\
\text { (cubic feet) }\end{array}$ \\
\hline September 27, 2007 & 0.13 & 298.5 & 0.13 & $>90$ & 61 & 3.3 \\
September 9, 2007 & 0.61 & 531.5 & 0.036 & 85 & 273 & 13 \\
October 26, 2008 & 0.78 & 87 & 0.108 & 70 & 357 & 55 \\
September 11, 2007 & 1.27 & 9.75 & 0.169 & 20 & 569 & 251 \\
September 26, 2008 & 2.97 & 105 & 0.17 & 60 & 1,274 & 295 \\
\hline
\end{tabular}

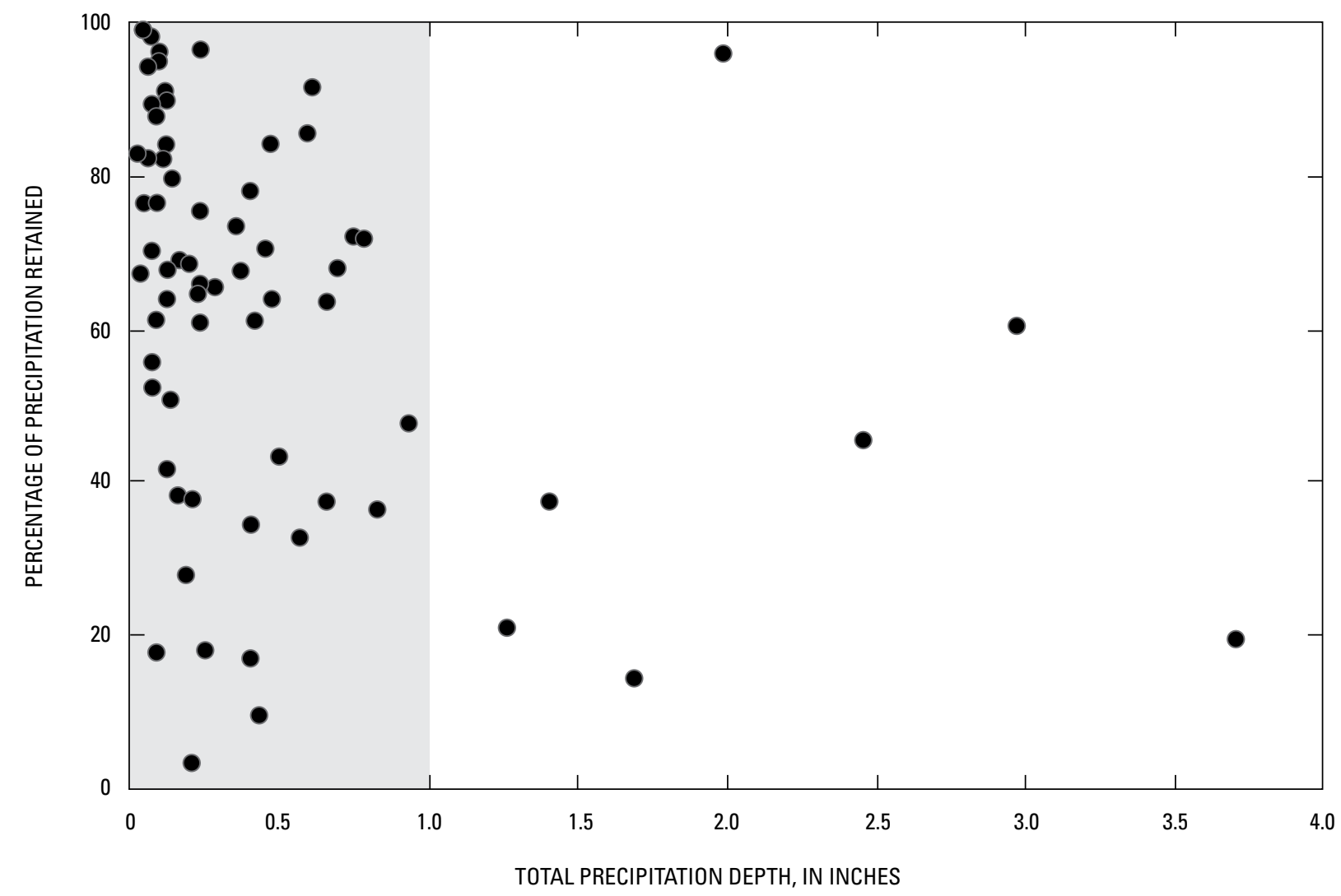

Figure 43. Percentage of precipitation retained by the Whipple Annex green roof in Ipswich, MA, in relation to total precipitation depth for storms that were monitored from June 2007 through November 2008. Grey-shaded area indicates storms that produced precipitation of less than 1 in. 


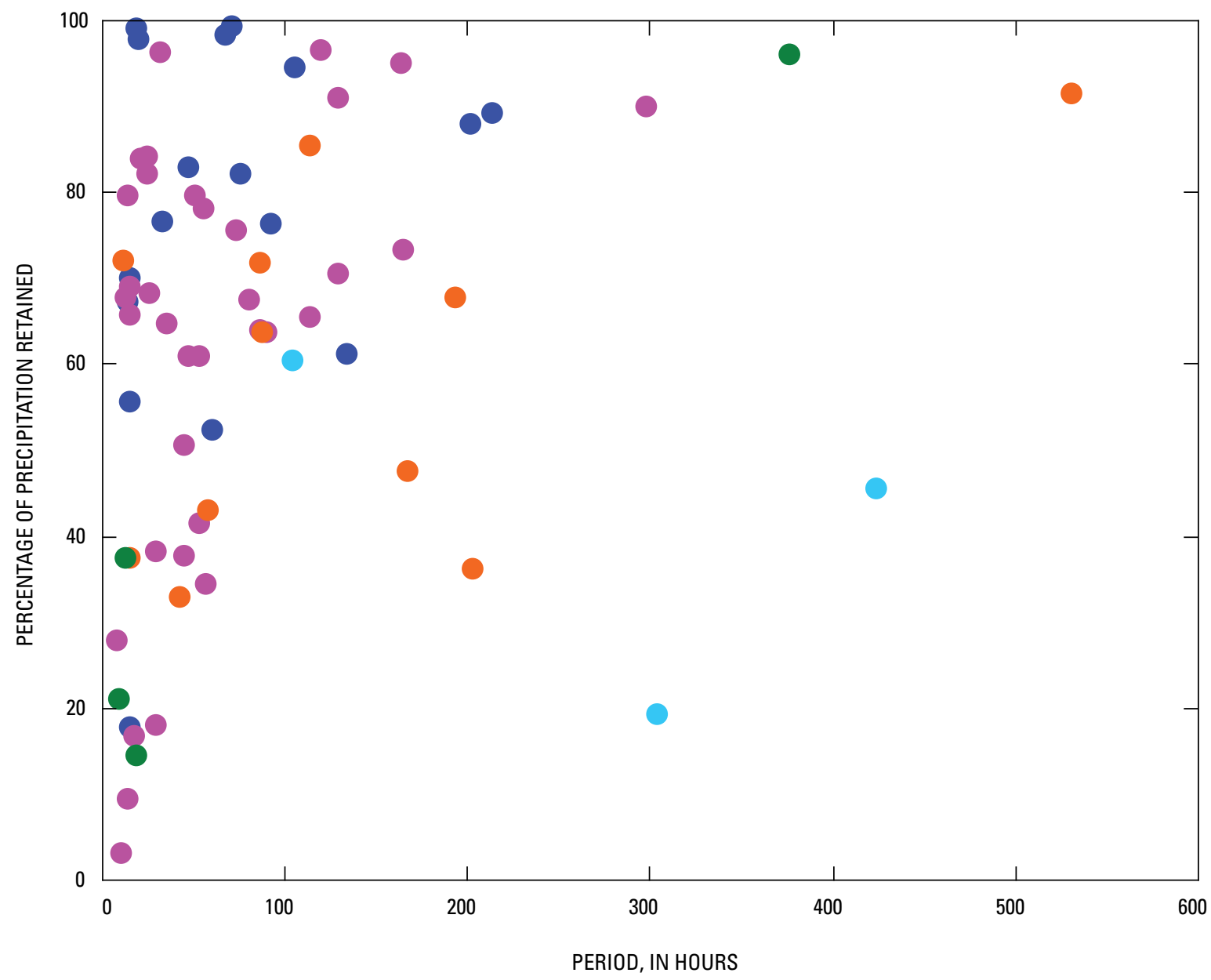

\section{EXPLANATION}

Total precipitation, in inches

0.0 to 0.09

0.1 to 0.49

0.5 to 0.99

1.0 to 1.99

greater than 1.99

Figure 44. Percentage of precipitation retained by the Whipple Annex green roof in Ipswich, MA, in relation to the length of the antecedent dry period and the total amount of precipitation for storms that were monitored from June 2007 through November 2008. 

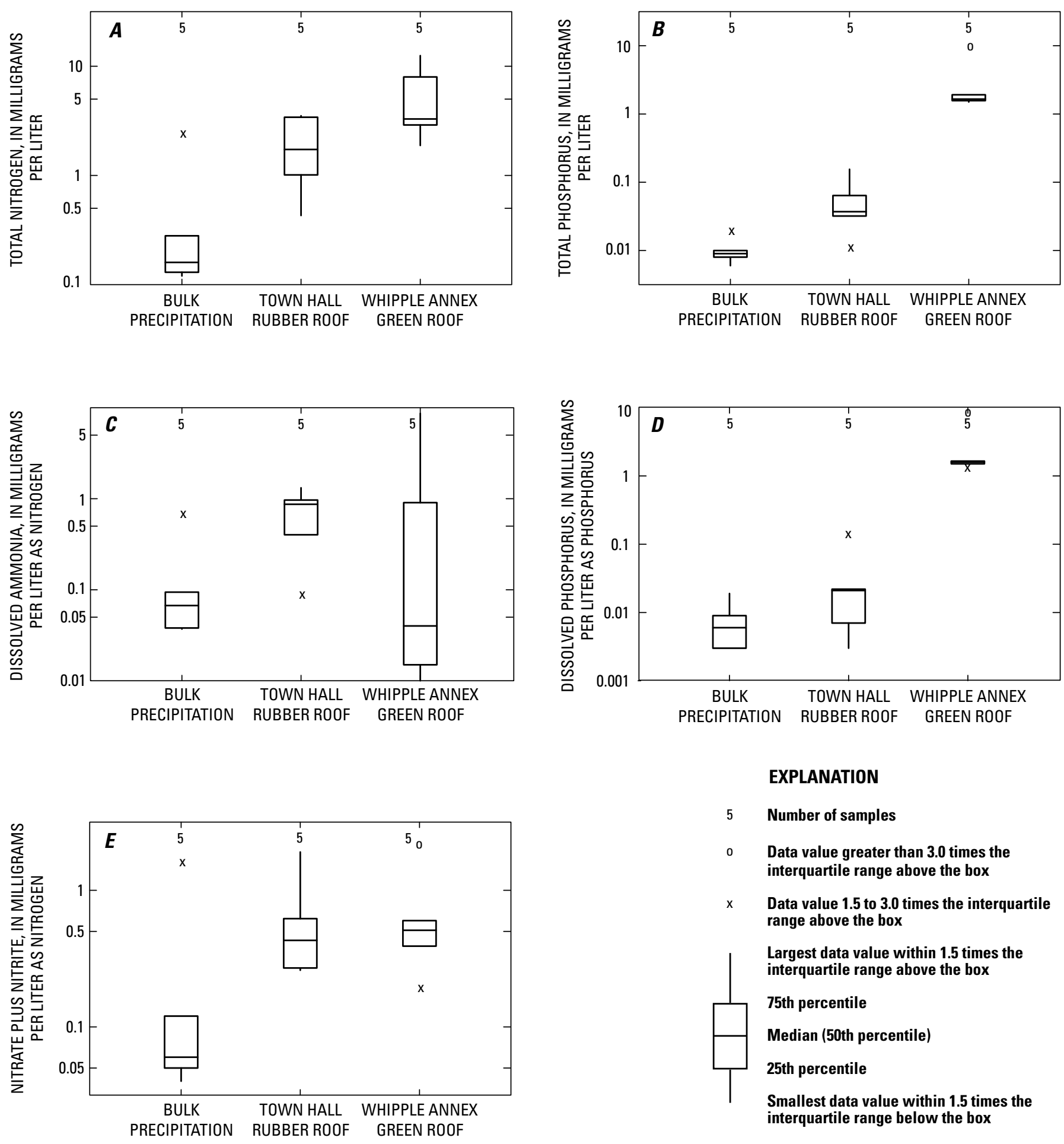

EXPLANATION

$5 \quad$ Number of samples

$0 \quad$ Data value greater than 3.0 times the interquartile range above the box

$x \quad$ Data value 1.5 to 3.0 times the interquartile range above the box

Largest data value within 1.5 times the interquartile range above the box

75th percentile

Median (50th percentile)

25th percentile

Smallest data value within 1.5 times the interquartile range below the box

$x \quad$ Data value 1.5 to 3.0 times the interquartile range below the box

Figure 45. Concentrations of $(A)$ total nitrogen, $(B)$ total phosphorus, $(C)$ dissolved ammonia nitrogen, $(D)$ dissolved phosphorus, and (E) nitrate plus nitrite nitrogen in bulk precipitation and in runoff from the town hall rubber roof and the Whipple Annex green roof, Ipswich, MA, June 2007 through November 2008. 

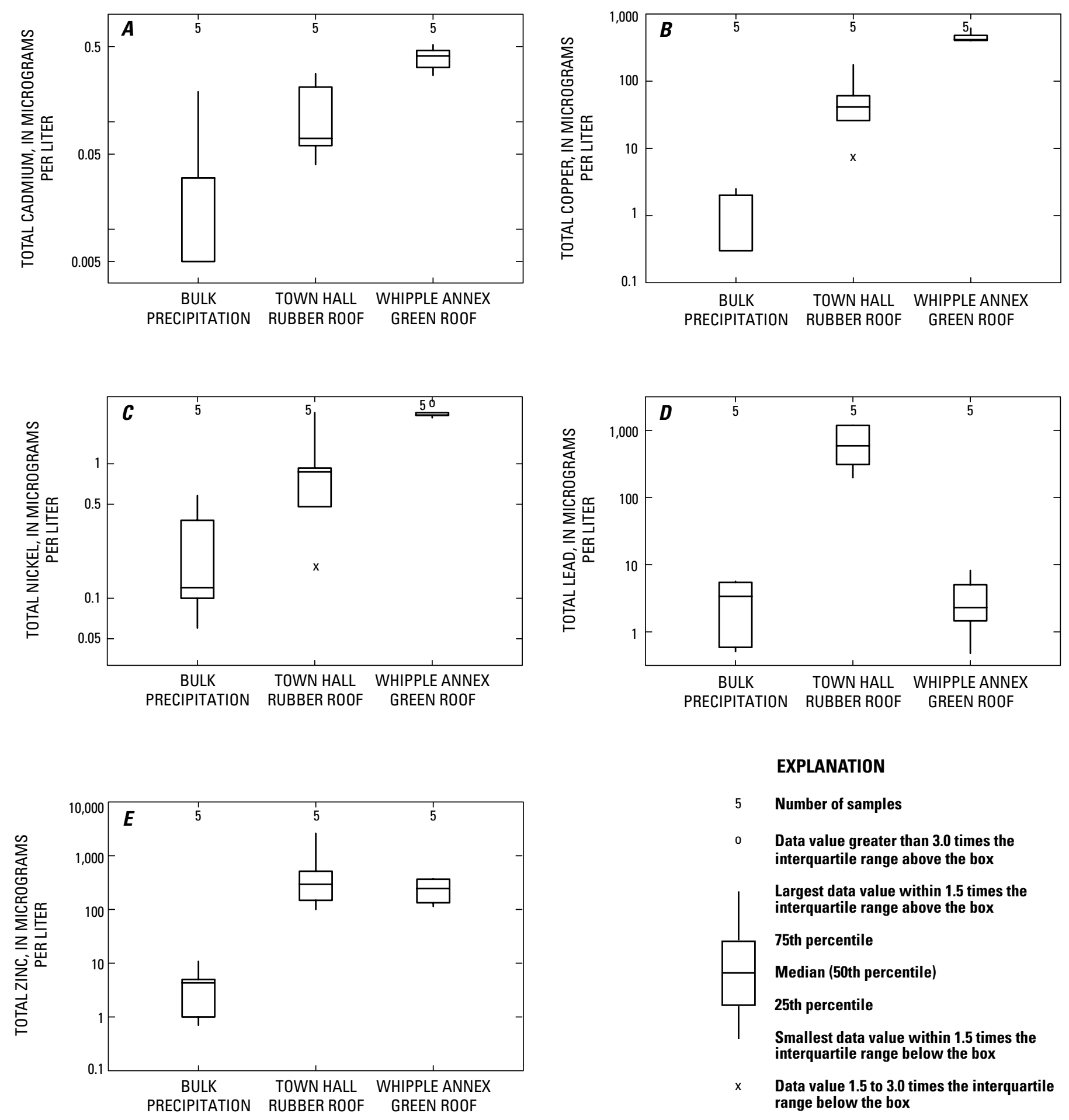

Figure 46. Concentrations of $(A)$ total cadmium, $(B)$ total copper, $(C)$ total nickel, $(D)$ total lead, and $(E)$ total zinc in bulk precipitation and in runoff from the town hall rubber roof and the Whipple Annex green roof, Ipswich, MA, June 2007 through November 2008. 
metals, with copper and zinc having the highest concentrations among the metals (table 2).

Results of analyses of quality-control replicate samples ( 6 blanks and 3 field replicates) collected during the roof study (table 2) were consistent with results from the environmental samples. Two analytes in separate environmental samples and their replicates, dissolved ammonia on July 9, 2008, and total nickel on October 21, 2008, had high relative percent difference (RPD) values (56.8 and 21.1 percent, respectively); other RPDs were less than 10 percent or could not be calculated because at least one value was less than the reporting level and (or) detection limit. The rare high RPD values do not detract from the overall consistency and quality of the data.

As in the calculations for Silver Lake runoff concentration boxplots and loads, the rare non-detects were replaced with values equal to half of their respective detection limits. This substitution had little effect on the nutrient calculations (the estimated loads were generally among the lowest values calculated). $\mathrm{Cu}$ in the bulk precipitation was the only metal affected, and the loads were small.

Median total and dissolved phosphorus concentrations in the green roof runoff were approximately one to two orders of magnitude greater than in either the rubber-membrane roof runoff or the bulk precipitation (figs. 45B, D). Median concentrations of most nitrogen analytes in runoff from the green roof were generally greater than in bulk precipitation or in runoff from the rubber-membrane roof (table 7); most of these differences were not statistically significant. Exceptions to this observation were the concentrations of total nitrogen, dissolved ammonia, and nitrate plus nitrite (figs. 45A, C, E). Median concentrations of total nitrogen from the green roof, rubber-membrane roof, and bulk precipitation were all statistically different from each other; the relatively high concentrations in green roof runoff could be due to breakdown of plant matter or release from the growing medium. Median concentrations of dissolved ammonia in runoff from the green roof were smaller than in either rubber-membrane roof runoff or bulk precipitation (fig. 45C); the relatively low concentrations may result from rapid absorption by the growing medium or by the vegetation. Dissolved nitrate plus nitrite median concentrations in green roof and rubber-membrane roof runoff were approximately equal, and both medians were greater than the median for bulk precipitation (fig. 45E). Differences among the median ammonia and nitrate plus nitrite concentrations were not statistically significant.

Median concentrations of $\mathrm{Cd}, \mathrm{Cu}$, and $\mathrm{Ni}$ were all substantially greater in runoff from the green roof than in rubbermembrane roof runoff or in bulk precipitation; however, only the $\mathrm{Cd}$ and $\mathrm{Cu}$ differences were statistically significant. On the other hand, the median concentration of $\mathrm{Pb}$ in the rubbermembrane roof runoff was two or more orders of magnitude greater than in bulk precipitation or in green roof runoff (fig. 46D); these differences were statistically significant. Median concentrations of $\mathrm{Zn}$ from the green and rubbermembrane roofs were about the same (fig. 46E), but both were more than an order of magnitude greater than in the bulk precipitation; the latter differences were statistically significant. The ranges of TPH concentrations were approximately equal (table 7) among collection sites.

For making comparisons among estimated loads of nutrients and metals in runoff and bulk precipitation, the calculated loads in the rubber-membrane roof runoff and bulk precipitation were normalized to the area of the green roof. That is, to account for differences in surface area, the rubbermembrane roof runoff load was multiplied by the ratio of the green roof area to the area of the rubber-membrane roof, and the concentrations in bulk precipitation were multiplied by the volume of precipitation that fell on the green roof (using appropriate unit conversion factors). Estimated median loads of total and dissolved phosphorus were greatest from the green roof (fig. 47); the load of total phosphorus in green roof runoff was statistically greater than the load in bulk precipitation, and the load of dissolved phosphorus was statistically greater than the load in either bulk precipitation or rubber-membrane-roof runoff. Estimated median loads of ammonia were smaller for the green roof than for the rubber-membrane roof or the bulk precipitation; the estimated median nitrate plus nitrite loads were greatest for the rubber-membrane roof runoff and about equal for bulk precipitation and green-roof runoff. Among the median nitrogen-analyte loads, only the difference between the rubber-membrane roof and green roof runoff of ammonia was statistically significant.

Green roof runoff had the greatest estimated median loads of $\mathrm{Cd}, \mathrm{Cu}$, and $\mathrm{Ni}$ (fig. 48). Estimated median loads of $\mathrm{Pb}$ and $\mathrm{Zn}$ were greatest in runoff from the rubber-membrane roof. Median loads of $\mathrm{Cu}$ and $\mathrm{Zn}$ in runoff from the green roof and the rubber-membrane roof were statistically greater than those in bulk precipitation. Median loads of $\mathrm{Pb}$ in rubbermembrane roof runoff and bulk precipitation were statistically greater than that in green roof runoff; loads of $\mathrm{Pb}$ in rubbermembrane roof runoff, in turn, were statistically greater than those in bulk precipitation.

Likely sources of the nutrients, metals, and TPH found in runoff from the rubber-membrane roof consist of dry fall between storms, deposits left by flying animals (birds and insects), and precipitation, the latter as determined in the bulk precipitation analyses. These differences in the source of materials account for the differences between rubber-membrane roof runoff and bulk precipitation as evidenced by the previously discussed data.

Considering the orders-of-magnitude differences among the constituent concentrations in runoff and in bulk precipitation, and the differences among the estimated loads, it is apparent that the soil medium, including any fertilizer that may have been applied, is the likely source of the nutrients in the runoff, a finding also reported by Emilsson and others (2007). If, as expected, fertilization does not continue indefinitely, with future maturation of the vegetation, it is possible that the original nutrients in the medium will diminish, and the concentrations and loads in the runoff will decline. However, decaying plant matter may contribute to the water quality of roof runoff in the future. In addition, the concentrations of 
Table 7. Concentrations of nutrients, total metals, and total petroleum hydrocarbons in runoff from the Town Hall and Whipple Annex roofs, and bulk precipitation, Ipswich, MA, 2007-08.

[E, estimated value less than the reporting level; <, less than; M, detected but not quantifiable; --, missing or not calculated (median); ns, sample not collected]

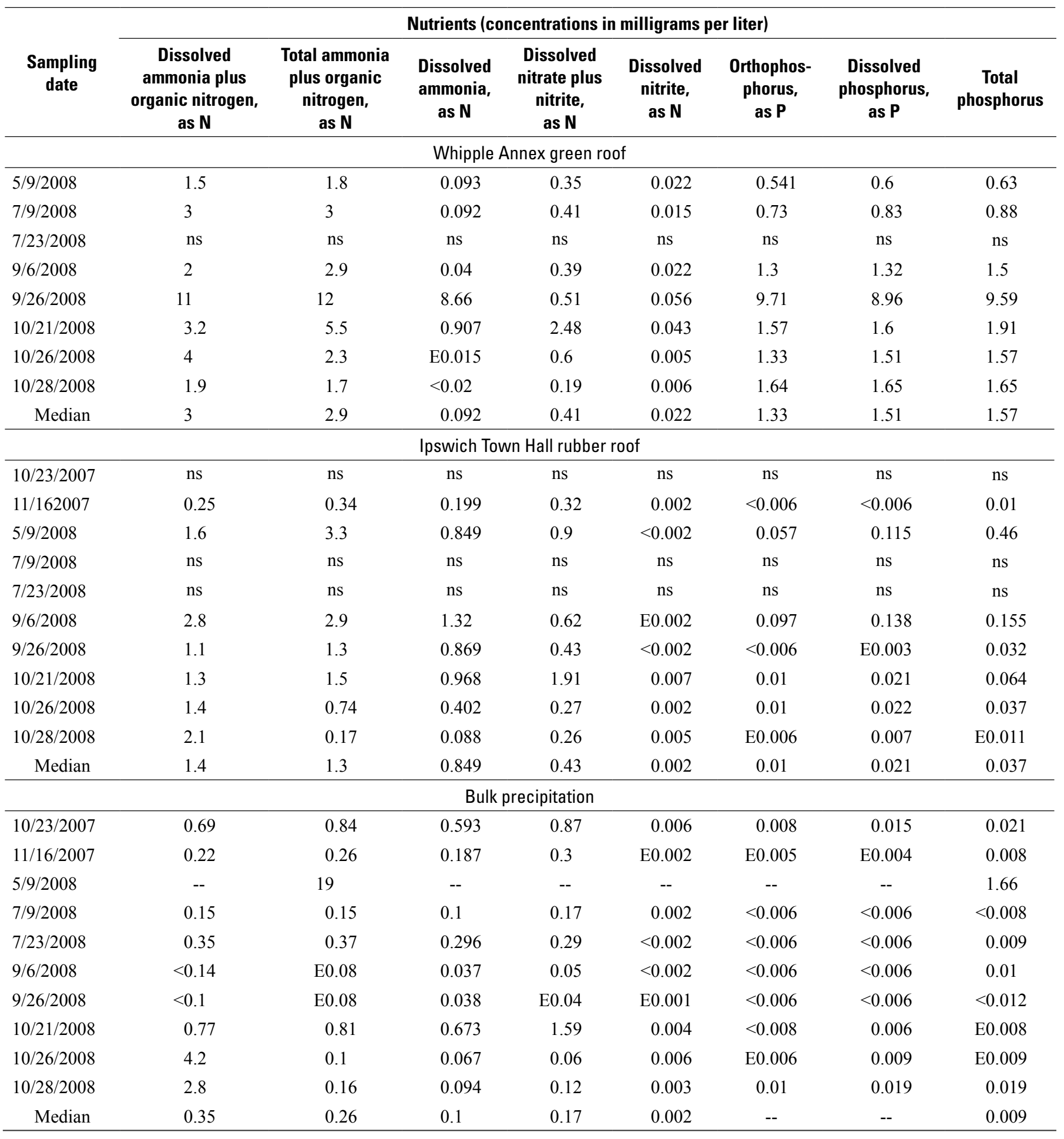


Table 7. Concentrations of nutrients, total metals, and total petroleum hydrocarbons in runoff from the Town Hall and Whipple Annex roofs, and bulk precipitation, Ipswich, MA, 2007-08.-Continued

[E, estimated value less than the reporting level; <, less than; M, detected but not quantifiable; --, missing or not calculated (median); ns, sample not collected]

\begin{tabular}{|c|c|c|c|c|c|c|c|}
\hline \multirow{2}{*}{$\begin{array}{l}\text { Sampling } \\
\text { date }\end{array}$} & \multicolumn{6}{|c|}{ Total metals (concentrations in micrograms per liter) } & \multirow{2}{*}{$\begin{array}{c}\text { Total } \\
\text { petroleum } \\
\text { hydrocarbons } \\
\text { (concentrations in } \\
\text { milligrams per liter) }\end{array}$} \\
\hline & Cadmium & Chromium & Copper & Lead & Nickel & Zinc & \\
\hline \multicolumn{8}{|c|}{ Whipple Annex green roof } \\
\hline $5 / 9 / 2008$ & 0.17 & $<1$ & 303 & 1.87 & 1.3 & 65.6 & -- \\
\hline 7/9/2008 & 0.83 & $<1$ & 590 & 1.59 & 3.5 & 384 & E4.1 \\
\hline $7 / 23 / 2008$ & ns & ns & ns & ns & ns & $\mathrm{ns}$ & 5 \\
\hline 9/6/2008 & 0.52 & $<1$ & 479 & 5.05 & 2.8 & 369 & E2 \\
\hline $9 / 26 / 2008$ & 0.27 & 1 & 405 & 1.46 & 2.3 & 133 & E2.1 \\
\hline $10 / 21 / 2008$ & 0.32 & 1 & 611 & 8.2 & 2.4 & 365 & -- \\
\hline $10 / 26 / 2008$ & 0.46 & $<1$ & 414 & 2.3 & 2.3 & 244 & E4.9 \\
\hline $10 / 28 / 2008$ & 0.41 & $<1$ & 402 & 0.48 & 2.2 & 114 & E1.5 \\
\hline Median & 0.41 & $<1$ & 414 & 1.87 & 2.3 & 244 & E3.1 \\
\hline \multicolumn{8}{|c|}{ Ipswich Town Hall rubber roof } \\
\hline $10 / 23 / 2007$ & ns & ns & ns & ns & ns & ns & -- \\
\hline $11 / 16 / 2007$ & 0.02 & $<1$ & 12.6 & 331 & 0.8 & 47.9 & 5 \\
\hline $5 / 9 / 2008$ & 0.1 & 5 & 57.9 & 1,020 & 2.5 & 200 & -- \\
\hline 7/9/2008 & ns & $\mathrm{ns}$ & $\mathrm{ns}$ & ns & ns & ns & -- \\
\hline $7 / 23 / 2008$ & ns & ns & ns & ns & ns & ns & E3.7 \\
\hline 9/6/2008 & 0.28 & 2 & 175 & 1,180 & 2.4 & 2610 & $<5$ \\
\hline $9 / 26 / 2008$ & 0.07 & 10 & 41.2 & 589 & 0.87 & 513 & E2.8 \\
\hline $10 / 21 / 2008$ & 0.21 & M & 60.6 & 1,190 & 0.93 & 293 & E2.8 \\
\hline $10 / 26 / 2008$ & 0.06 & $<1$ & 26 & 311 & 0.48 & 148 & E4.1 \\
\hline $10 / 28 / 2008$ & E0.04 & $<1$ & 7.2 & 197 & E0.17 & 100 & $<5$ \\
\hline Median & 0.07 & -- & 41.2 & 321 & 0.8 & 200 & -- \\
\hline \multicolumn{8}{|c|}{ Bulk precipitation } \\
\hline $10 / 23 / 2007$ & 2.38 & $\mathrm{M}$ & 5.9 & 9.64 & 3.8 & 36.6 & -- \\
\hline $11 / 16 / 2007$ & 0.08 & $<1$ & 3.9 & 9.2 & 4 & 3.9 & $<2$ \\
\hline $5 / 9 / 2008$ & -- & -- & -- & -- & -- & -- & -- \\
\hline $7 / 9 / 2008$ & E0.01 & $<1$ & $<1.2$ & 12.1 & E0.12 & 8.1 & E4.6 \\
\hline $7 / 23 / 2008$ & E0.01 & $<1$ & $<1.2$ & 7.36 & E0.1 & 2.6 & E2.3 \\
\hline 9/6/2008 & 0.01 & $<1$ & $<1.2$ & 0.51 & E0.12 & E1.4 & E2.6 \\
\hline $9 / 26 / 2008$ & 0.01 & $<1$ & $<1.2$ & 0.59 & E0.06 & $<2$ & E3.2 \\
\hline $10 / 21 / 2008$ & 0.19 & $<1$ & E2.5 & 5.65 & 0.38 & 10.8 & -- \\
\hline $10 / 26 / 2008$ & 0.06 & $<1$ & $<4$ & 5.46 & $<0.2$ & 5 & E7.3 \\
\hline $10 / 28 / 2008$ & 0.06 & $<1$ & $<4$ & 3.38 & 0.58 & 4.3 & $<5$ \\
\hline Median & 0.06 & $<1$ & -- & 5.65 & E0.12 & 4.3 & -- \\
\hline
\end{tabular}



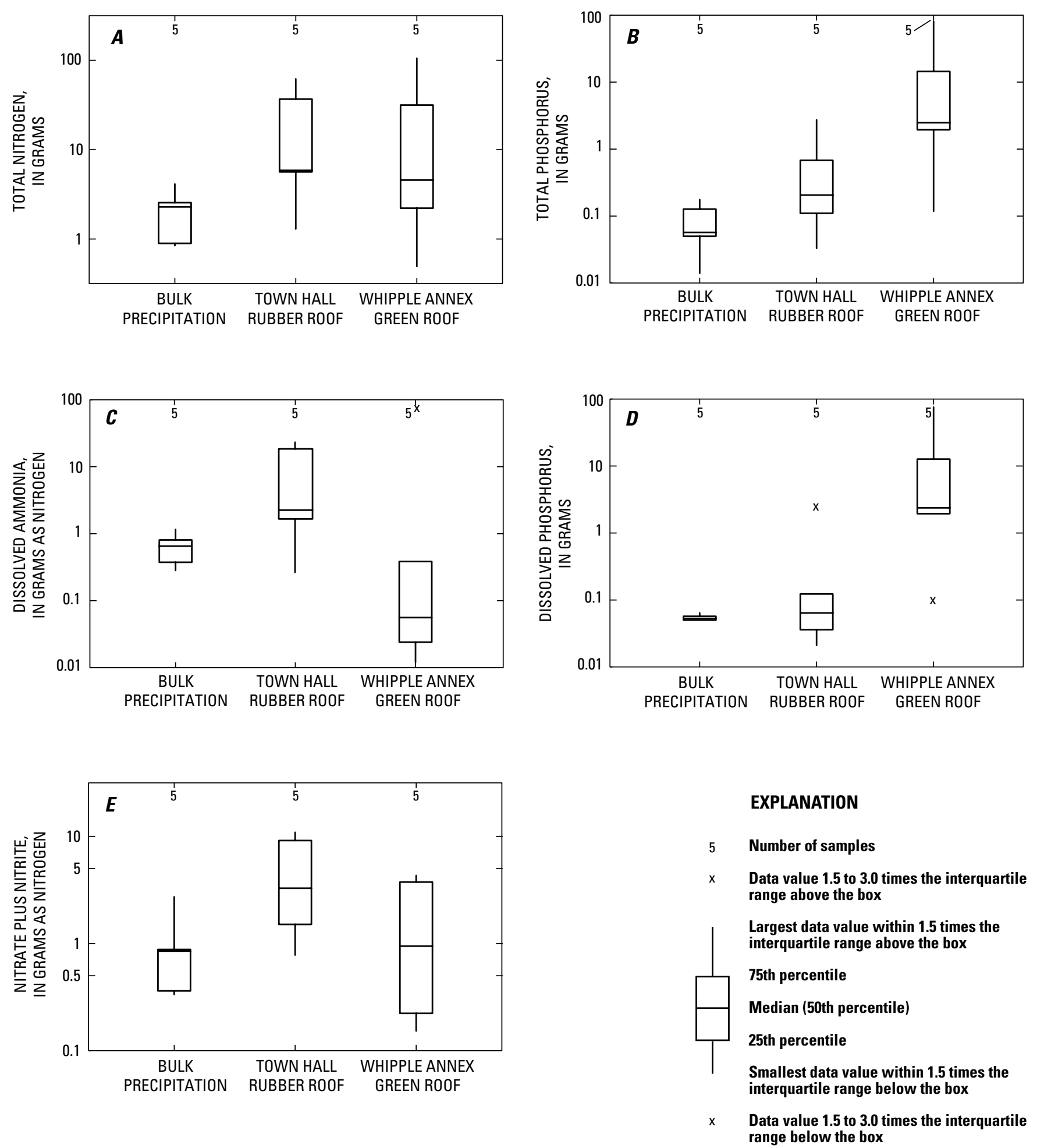

Figure 47. Loads of $(A)$ total nitrogen, $(B)$ total phosphorus, $(C)$ dissolved ammonia nitrogen, $(D)$ dissolved phosphorus, and $(E)$ nitrate plus nitrite nitrogen in bulk precipitation and in runoff from the town hall rubber roof and the Whipple Annex green roof, Ipswich, MA, June 2007 through November 2008. 

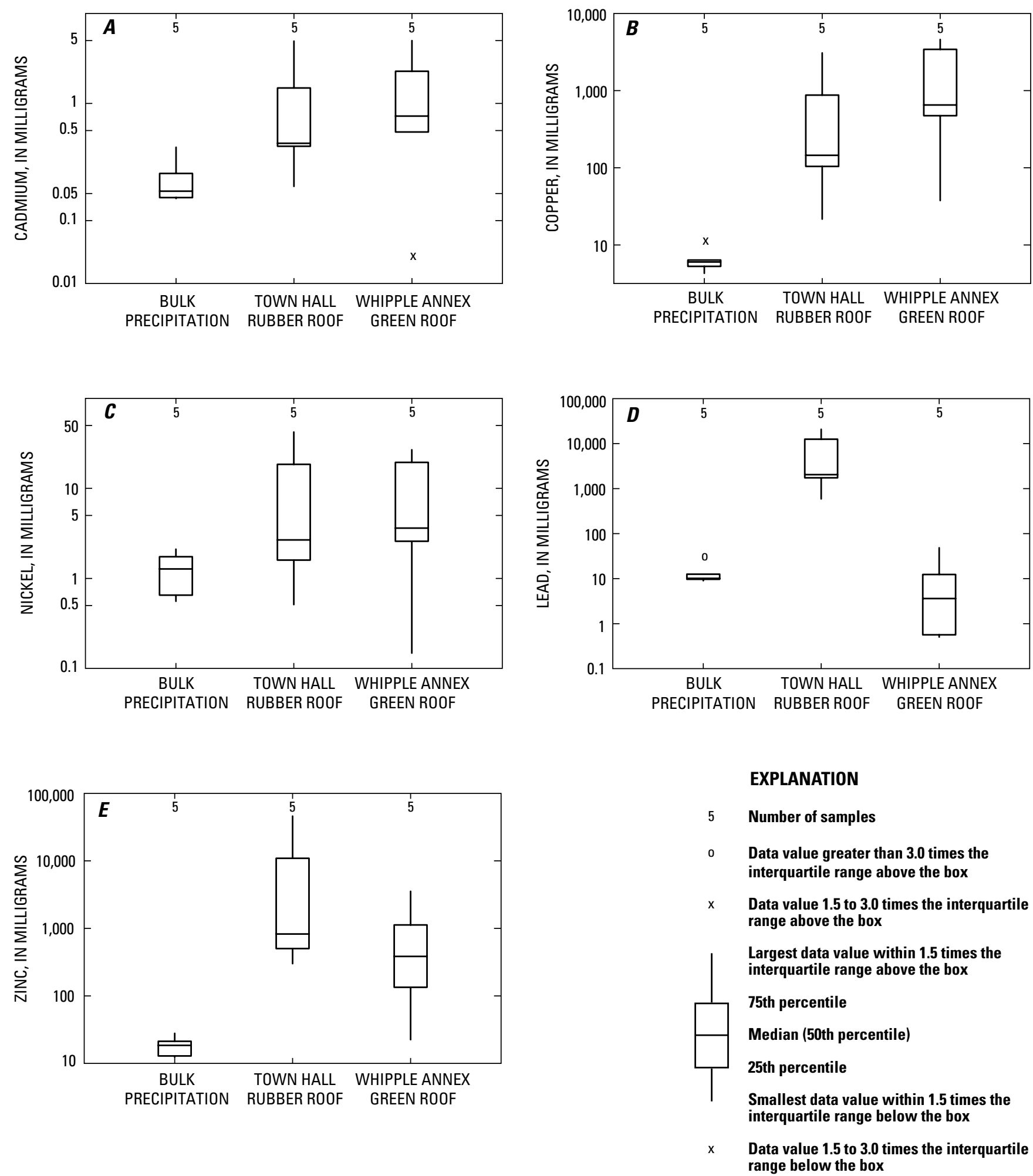

Figure 48. Loads of $(A)$ total cadmium, $(B)$ total copper, $(C)$ total nickel, $(D)$ total lead, and $(E)$ total zinc in bulk precipitation and in runoff from the town hall rubber roof and the Whipple Annex green roof, Ipswich, MA, June 2007 through November 2008. 
copper and zinc in the soil slurry sample also are probably related to the concentrations and loads in runoff. Furthermore, the gutters, downspouts, machinery, vents, and copper flashing on the green roof all probably contribute to the chemical makeup of the runoff (fig. 33). Of the metals in the rubbermembrane roof runoff, lead and zinc are most notable for the high concentrations and estimated loads; these two metals are commonly found in the old pipes that drain the roof.

One of the features claimed for green roofs is the ability to sequester some atmospheric pollutants. With the exception of ammonia and nitrate plus nitrite, the concentrations of the nutrient analytes in bulk precipitation and rubber-membrane roof runoff samples are generally small fractions of the concentrations detected in the green roof runoff. Therefore, in general, the sequestration of atmospheric contaminants appears to be offset by the release of these constituents from the growing medium and plants, and from fertilization.

\section{Simulation of the Effects of Land-Use Change and Low-Impact Development on Streamflow at Multiple Spatial Scales}

The USGS, in cooperation with the MDCR and the USEPA, used the calibrated Ipswich River Basin Hydrological Simulation Program-FORTRAN (HSPF) precipitation-runoff model (Zarriello and Ries, 2000) to simulate the effects of various LID and water-conservation practices on streamflow at multiple spatial scales. Urbanization produces changes in land use and stormwater routing that have significant effects on the processes that generate streamflow. Loss of vegetation, increased imperviousness, and large-scale water infrastructure (water withdrawals and wastewater return flows) affect the entire flow regime from flood peaks to summer low flows maintained by groundwater discharge. To evaluate the effects of LID and water-conservation practices on streamflow using HSPF, the original model of Zarriello and Ries (2000) was modified to simulate hypothetical land-use changes and water-management scenarios developed by the USGS in consultation with MDCR, USEPA, and a Technical Advisory Committee created for the project. Specific LID practices, such as installation of porous pavement, rain gardens, bioretention areas, or green roofs, could not be represented explicitly in the HSPF model; rather, surrogates for these practices were simulated by changing patterns of land use and the amount of EIA in the basin.

Two types of simulations were conducted for this study. The first type simulated the effects of land-use change, LID practices, and water-conservation efforts in subbasins with heterogeneous land use, as structured to represent the basin in the original HSPF model. These simulations (referred to hereafter as basin-scale simulations) generally were conducted for the entire basin or for the drainage area above the USGS
South Middleton streamgage (station 01101500), also referred to as the upper basin. Results for these simulations represent hydrologic processes in drainage areas ranging from about 0.5 to $125 \mathrm{mi}^{2}$ in size (fig. 49). The second type simulated small drainage areas consisting of mainly homogeneous land uses to evaluate the potential effects on streamflow of land-use change, LID practices such as clustered housing developments, and the amount of EIA. These simulations (referred to hereafter as local-scale simulations) represent hydrologic processes in hypothetical 100 -acre $\left(0.16 \mathrm{mi}^{2}\right)$ drainage areas. The local-scale simulations do not represent actual drainage areas in the basin, but because model-calibrated parameter values were used in the simulations, simulation results represent potential streamflow response in the Ipswich River Basin. Overall, the two types of simulations show the hydrologic responses to land-use change, water-management activities, and various LID practices over a wide range of spatial and temporal scales and patterns of land use.

The Ipswich River Basin HSPF model simulates the magnitude of streamflow only. The effects of urbanization and the potential mitigating effects of LID on other stream characteristics such as water quality (for example, concentrations of nutrients, metals, bacteria, and sediment), water temperature, channel stability, and aquatic ecology were not evaluated with the model.

\section{Description of Original Baseline Model}

The original baseline model refers to the calibrated Ipswich River Basin HSPF model ${ }^{2}$ described by Zarriello and Ries (2000) that consists of 15 pervious (PERLND) and 2 impervious (IMPLND) hydrologic response units (HRUs) that have unique combinations of land use and surficial geology (table 7 in Zarriello and Ries, 2000). A surficial geology data layer consisting of two categories (1) till and (2) sand and gravel) and a 1991 land-use data layer were used to develop the HRUs for the original baseline model. IMPLNDs do not allow infiltration and are defined as impervious surfaces that are directly connected to the stream network. Thus, IMPLNDs hydrologically represent EIAs. PERLNDs allow infiltration and are assigned HSPF parameter values to represent the specific land-use and subsurface characteristics of the land segment. Surface flow from IMPLNDs and surface and subsurface flows from PERLNDs are directed to 67 river reaches or reservoir segments (RCHRES) that represent the hydraulic network of the basin (fig. 49; table 8 in Zarriello and Ries, 2000). The original baseline model was calibrated to streamflow data from the USGS streamgage at South Middleton and at Ipswich (station 01102000) for the period 1989 to 1993. Climate data for the period 1961 to 1995 were provided by the Marine Biological Laboratory in Woods Hole, MA (Zarriello and Ries, 2000).

${ }^{2}$ Bicknell and others (2000) provide a detailed description of the structure and capabilities of the HSPF model. 


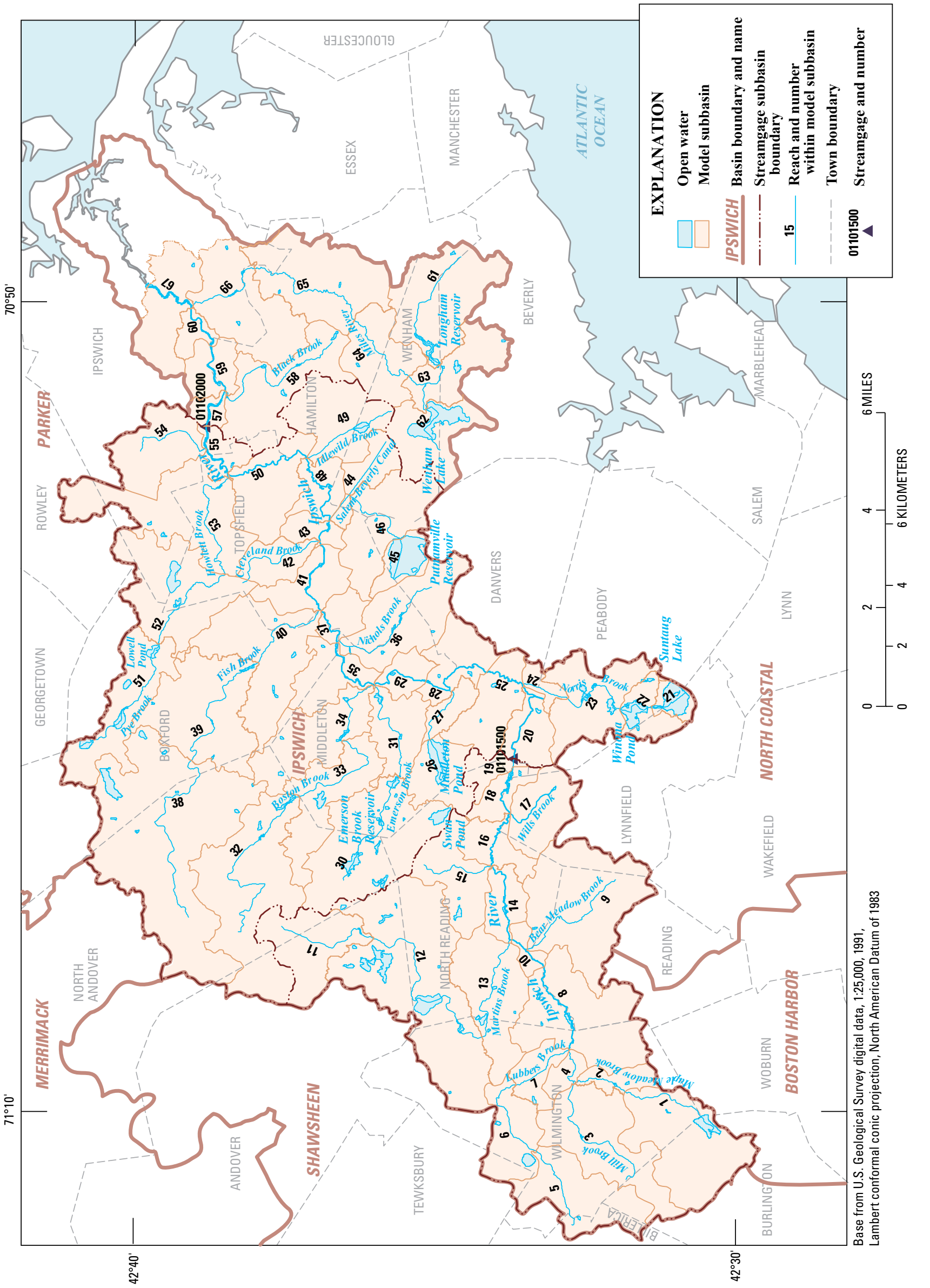

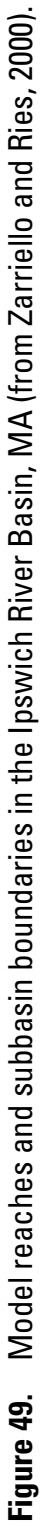


Time series of total groundwater and surface-water withdrawals were developed for reaches with municipal withdrawals during the calibration period. By quantifying withdrawals during the calibration period, the effects of withdrawals were included in the simulation so that the hydrologic parameters were not skewed. Daily withdrawals were obtained or estimated from monthly records for all major groundwater and surface-water withdrawals in the basin for the calibration period (or longer, when available). The original baseline model contained a total of 73 withdrawals, most of which were municipal groundwater withdrawals (table 3 in Zarriello and Ries, 2000). For time-varying groundwater withdrawals, the analytical program STRMDEPL (Barlow, 2000) was used to calculate rates of streamflow depletion. The streamflowdepletion rate reflected the time-delayed response to changes in the rate of withdrawal; the response was a function of the distance to the well from the stream and the hydraulic properties of the aquifer. Surface-water withdrawals and streamflowdepletion rates from individual wells were combined to obtain the total streamflow-depletion rate for each reach affected by withdrawals.

For the long-term (1961-1995) simulations conducted for this study, withdrawals for periods during which actual withdrawals were not obtained (generally from January 1961 through December 1988 and January 1994 through December 1995) were estimated from the average monthly streamflowdepletion rates for a period when withdrawals were available (generally 1989-1993). Thus, the long-term simulations compute streamflow for average 1989-1993 withdrawal conditions, constant land-use conditions (1991 land use), and actual, long-term climatic conditions.

\section{Modifications to the Original Baseline Model}

In this study, the calibrated HSPF model was modified to simulate five newly defined basin-scale scenarios. For each scenario, a new model control file (uci) was created. For the scenarios that incorporate withdrawal changes, new time series of streamflow-depletion rates were computed and stored in unique data-set numbers in the associated Water Data Management file for the Ipswich River Basin HSPF model. For the scenarios that incorporate land-use and EIA changes, new HRUs were created and copied into the schematic block of the uci file, as appropriate. For the hypothetical local-scale simulations, selected existing HRUs were re-sized to 100 acres to simulate runoff from small drainage areas with uniform land use. HRU and stream reach parameter values and climatic data from the original baseline model of Zarriello and Ries (2000) were not altered for this study. Specific modifications made to the calibrated model for each scenario are described in greater detail in the "Description of Basin-Scale and Local-Scale Simulations" section of the report.

\section{Model Limitations}

Because of limits on data availability and computational efficiency, numerical watershed models such as HSPF simplify the complex processes and physical characteristics of a drainage basin. Consequently, there are limitations to the types of questions that can be addressed by the model. The assumptions, information used to develop and calibrate the model, spatial resolution of the model, and the possible applicability of alternative model structures and parameter values need to be considered when evaluating the model results for waterresources management decisions. Limitations and uncertainties of the Ipswich River Basin HSPF model are described in greater detail in Zarriello and Ries (2000).

Model calibration reflects the combined effects of HRUs (PERLNDs and IMPLNDs) and reach characteristics. Hydrologic judgment was used to determine parameter values for the PERLNDs and IMPLNDs, but information was not available to calibrate the response for individual HRUs. In addition, the EIA associated with each developed land-use category was determined through model calibration. Calibrated EIA values in the original baseline model are 63 percent for commercialindustrial-transportation land use (hereafter referred to as commercial land use), 14 percent for high-density residential $(<0.5$-acre lots) land use, and 2.5 percent for low-density residential ( $>0.5$-acre lots) land use. These values represent average subbasin-scale EIA; however, the local variability of EIA for a given type of development in the basin (for example, Roy and Shuster, 2009) could not be represented in the model. Despite the uncertainties associated with estimating EIA through model calibration, the model-calibrated values for commercial and residential areas in the Ipswich River Basin are consistent with values for similar broad land-use categories computed from rainfall-runoff relations in the Charles River Basin (Zarriello and Barlow, 2002) and values in the literature (Alley and Veenhuis, 1983). To evaluate the sensitivity of simulated streamflow to EIA, this basin property was varied in many of the simulations conducted for this study. The use of EIA as a surrogate for LID was considered reasonable given the number of different LID practices that would need to be explicitly represented in the model and the large scale of most of the simulations. One consequence of using EIA as a surrogate for LID is that specific LID practices designed to improve infiltration capacity in the pervious areas (for example, adding permeable soil to improve subsurface storage, re-grading the site, or installing detention structures) were not represented. Therefore, the model may underestimate the effects of LID on streamflow in the few simulations where enhanced infiltration from LID affects a large fraction of the drainage area and the underlying soil is not already permeable (that is, areas underlain by till).

Lastly, when the original baseline model was calibrated, the degree to which simulated flows were in agreement with actual flows could not be determined at most locations because most of the reaches in the basin were ungaged. Therefore, simulation results from ungaged areas or magnitudes of changes 
in flows produced by altering the distribution of HRUs were uncertain. Overall, simulated streamflow responses were viewed as relative rather than absolute.

\section{Description of Basin-Scale and Local-Scale Simulations}

This section describes the simulations developed by the USGS in consultation with MDCR, USEPA, and the Technical Advisory Committee (table 8). Two types of simulations, basin-scale simulations and local-scale simulations, were conducted.

\section{Basin-Scale Simulations}

The basin-scale simulations were conducted for either the entire basin (original baseline simulation, updated baseline simulation, buildout simulation, and water-conservation simulation) or the upper basin above the South Middleton streamgage (LID retrofit simulation). Specific LID practices involving land-use change were not represented explicitly in the HSPF model; rather, surrogates for these practices were simulated by changing patterns of land use and the amount of model-calibrated EIA. Other practices, such as hypothetical reductions in withdrawal rates through water conservation and major changes in groundwater withdrawals by the towns of Reading and Wilmington, were simulated directly with the model.

\section{Original Baseline Simulation}

The original long-term baseline simulation was conducted previously with the original baseline model to evaluate the effects of average 1989-1993 withdrawals on streamflow over long-term (1961-1995) climatic conditions (Zarriello and Ries, 2000). For simulations incorporating updated withdrawals for Reading and Wilmington, discussed in the following section, withdrawal amounts were altered from the average 1989-1993 rates.

\section{Updated Baseline Simulation}

The original, long-term, baseline simulation was updated to incorporate major changes in the withdrawals for the towns of Reading and Wilmington that have occurred since the original baseline model was developed. In the original baseline simulation, both towns relied entirely on groundwater withdrawals from wells in the upper part of the basin.

In 2006, the town of Reading began purchasing water from the MWRA to meet its water needs. To simulate current conditions for Reading, withdrawals for the 10 Reading Water Department wells in reach 8 (fig. 50) that were in service for the original baseline simulation were removed from the updated baseline simulation. This change resulted in Reading withdrawals decreasing from an average of $2.2 \mathrm{Mgal} / \mathrm{d}$ in the original baseline simulation to $0.037 \mathrm{Mgal} / \mathrm{d}$ in the updated baseline simulation (minor withdrawals for Meadow Brook Golf Club remained in the model).

In 2008, the town of Wilmington anticipated satisfying some of its summer demand with purchases from the MWRA (Michael Wood, Town of Wilmington, written commun., 2008), but because changes to the water-supply system had not yet been implemented, only projected changes provided by the town were simulated. At the time of this study, Wilmington obtained water from four wells: Shawsheen Avenue in reach 5, Browns Crossing in reach 12, and Barrows wellfield and Salem Street in reach 13 (fig. 50). To represent current (2008) withdrawals from each well, daily withdrawal rates for 2006 to 2007 were averaged to produce a single year of daily

Table 8. Description of scenarios simulated with the Hydrological Simulation Program-FORTRAN precipitation runoff model of the Ipswich River Basin, Ipswich, MA.

[DSN, dataset number in the Watershed Data Management (WDM) database; long-term (1961-1995) simulations conducted for all scenarios]

\begin{tabular}{|c|c|c|}
\hline Scenario identifier & Description & Output DSN \\
\hline \multicolumn{3}{|c|}{ Basin-scale scenarios simulated } \\
\hline LT-Demd & $\begin{array}{l}\text { Original baseline simulation (Zarriello and Ries, 2000)_-1989-1993 withdrawals (also } \\
\text { referred to as original baseline withdrawals), } 1991 \text { land use. }\end{array}$ & $6501-6567$ \\
\hline LID-LT-upDem & $\begin{array}{l}\text { Updated baseline simulation-1989-1993 withdrawals with updated withdrawals for } \\
\text { Reading and Wilmington (also referred to as updated baseline withdrawals), } 1991 \text { land use. }\end{array}$ & $7501-7567,8501-8567$ \\
\hline LID_LT-conserv & $\begin{array}{l}\text { Water-conservation simulation-updated baseline withdrawals with rates reduced by } 1 \text { to } \\
20 \text { percent to represent water-conservation programs, } 1991 \text { land use. }\end{array}$ & $7801-7867,8801-8867$ \\
\hline \multicolumn{3}{|c|}{ Local-scale scenarios simulated } \\
\hline LID_LT-local & $\begin{array}{l}\text { Local-scale simulations (100-acre parcels) - no water withdrawals, varying combinations of } \\
\text { developed and undeveloped land-use types and amounts of effective impervious area. }\end{array}$ & $3001-3031$ \\
\hline
\end{tabular}




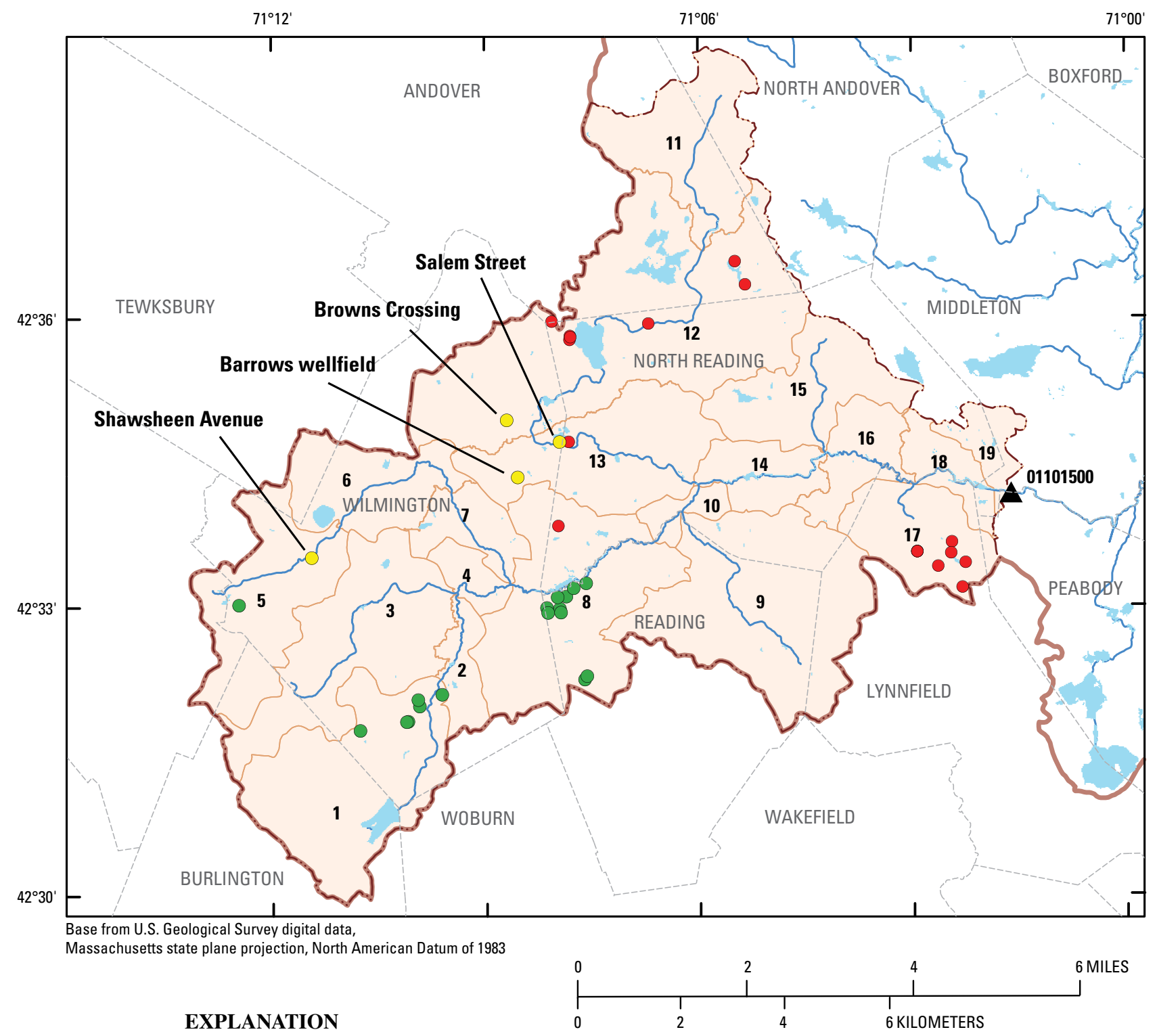

Hydrology

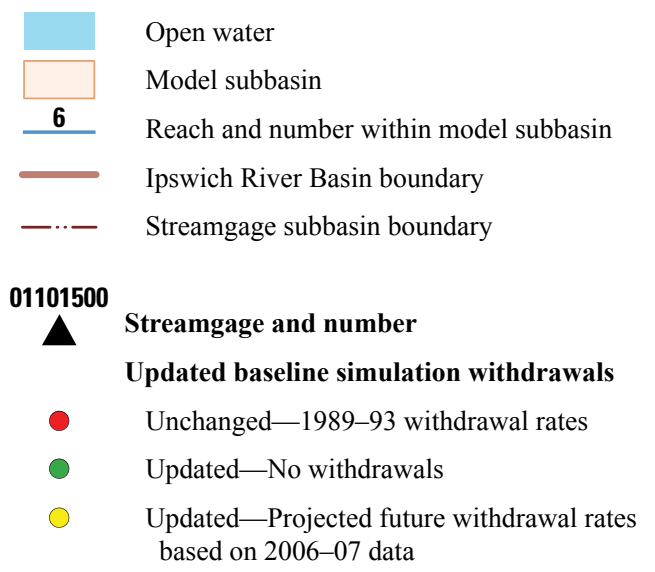

Figure 50. Changes in groundwater withdrawals for Reading and Wilmington, MA, for the updated baseline simulation relative to the original baseline simulation. 
Table 9. Changes to the Wilmington, MA, water-supply system for the updated baseline simulation.

[Mgal/d, million gallons per day; MWRA, Massachusetts Water Resources Authority; Updated 2006-2007 withdrawal rates represent projected future withdrawals and are referred to as updated baseline withdrawals in the model simulations.]

\begin{tabular}{rlcccccc}
\hline $\begin{array}{c}\text { Model } \\
\text { reach }\end{array}$ & \multicolumn{1}{c}{ Well name } & $\begin{array}{c}\text { Average } \\
\mathbf{1 9 8 9 - 1 9 9 3} \\
\text { withdrawal } \\
\text { rate } \\
\text { (Mgal/d) }\end{array}$ & $\begin{array}{c}\text { Average } \\
\mathbf{2 0 0 6 - 2 0 0 7} \\
\text { withdrawal } \\
\text { rate } \\
\text { (Mgal/d) }\end{array}$ & $\begin{array}{c}\text { Average } \\
\mathbf{2 0 0 6 - 2 0 0 7} \\
\text { May-September } \\
\text { withdrawal rate } \\
\text { (Mgal/d) }\end{array}$ & $\begin{array}{c}\text { Projected } \\
\text { May-September } \\
\text { change due to } \\
\text { MWRA purchases } \\
\text { (Mgal/d) }\end{array}$ & $\begin{array}{c}\text { Updated average } \\
\text { 2006-2007 } \\
\text { withdrawal } \\
\text { rate } \\
\text { (Mgal/d) }\end{array}$ & $\begin{array}{c}\text { Updated } \\
\text { 2006-2007 } \\
\text { May-September } \\
\text { withdrawal rate } \\
\text { (Mgal/d) }\end{array}$ \\
\hline 5 & Shawsheen Avenue & 0.161 & 0.511 & 0.551 & -0.551 & 0.280 & 0 \\
12 & Browns Crossing & 1.47 & 0.569 & 0.572 & -0.300 & 0.443 \\
13 & Barrows & 0.656 & 0.392 & 0.391 & -0.150 & 0.330 \\
13 & Salem Street & 0 & 0.471 & 0.522 & 0 & 0.272 \\
\end{tabular}

flows. Average withdrawal rates for 2006 to 2007 ranged from $0.392 \mathrm{Mgal} / \mathrm{d}$ (Barrows) to $0.569 \mathrm{Mgal} / \mathrm{d}$ (Browns Crossing); the total rate from the four wells was $1.94 \mathrm{Mgal} / \mathrm{d}$ (table 9). Wilmington also purchased 0.2 to $0.5 \mathrm{Mgal} / \mathrm{d}$ from MWRA during the summer and anticipated purchasing an additional $1 \mathrm{Mgal} / \mathrm{d}$ to supplement summer supplies (Michael Wood, Town of Wilmington, written commun., 2008). The anticipated additional purchases from the MWRA were incorporated into the updated baseline simulation by reducing average 2006-2007 summer (May through September) withdrawal rates. On the basis of information provided by the town, rates were reduced by $0.551 \mathrm{Mgal} / \mathrm{d}$ at the Shawsheen Avenue well, $0.300 \mathrm{Mgal} / \mathrm{d}$ at the Browns Crossing well, and $0.150 \mathrm{Mgal} / \mathrm{d}$ at Barrows well. Rates were unchanged at the Salem Street well (table 9). These changes resulted in a total reduction for the town of about $1 \mathrm{Mgal} / \mathrm{d}$ (from 2.04 Mgal/d in 2006 to 2007 to $1.04 \mathrm{Mgal} / \mathrm{d}$ in the updated baseline simulation) during the summer months. For each well, streamflow depletion then was computed from the modified annual time series of daily withdrawals, and long-term time series for 1961 to 1995 was developed as described in the Model Development section of this report. All other aspects of the original baseline simulation by Zarriello and Ries (2000) remained unchanged in the updated baseline simulation.

Changes to Wilmington withdrawals directly affected simulated streamflow (fig. 50) in reaches 1, 5, 12, and 13 as described below.

Reach 1. Average streamflow depletion from Maple Meadow Brook at Route 38 in Wilmington (reach 1) decreased from $1.08 \mathrm{Mgal} / \mathrm{d}$ in the original baseline simulation (five wells) to $0 \mathrm{Mgal} / \mathrm{d}$ in the updated baseline simulation (no wells). Five Wilmington wells that were in operation during the 1989-1993 calibration period were no longer in service.

Reach 5. Average streamflow depletion from Lubbers Brook above Route 38 in Wilmington (reach 5) increased from $0.16 \mathrm{Mgal} / \mathrm{d}$ in the baseline simulation (two wells) to $0.27 \mathrm{Mgal} / \mathrm{d}$ in the updated baseline simulation (one well). The average streamflow depletion rate increased because the Shawsheen Avenue well was pumped at a higher rate than the combined rate of the two wells in operation during the
1989-1993 calibration period; however, summer streamflow depletion was lower for the updated baseline simulation than for original baseline simulation because of the anticipated purchases from the MWRA.

Reach 12. Average streamflow depletion from Martins Brook at Route 62 in North Reading (reach 12) decreased from $1.23 \mathrm{Mgal} / \mathrm{d}$ in the original baseline simulation (three wells) to $1.06 \mathrm{Mgal} / \mathrm{d}$ in the updated baseline simulation (three wells). The simulations had the same number of withdrawals, but the updated baseline simulation reflected lower average and summer pumping rates from the Browns Crossing well.

Reach 13. Average streamflow depletion from Martins Brook upstream from the mouth in North Reading (reach 13) increased slightly from $0.91 \mathrm{Mgal} / \mathrm{d}$ in the original baseline simulation (two wells) to $1.03 \mathrm{Mgal} / \mathrm{d}$ in the updated baseline simulation (three wells). The overall rate increased because the Salem Street well was not in operation during the 1989-1993 calibration period. As for the other reaches affected by MWRA purchases, summer streamflow depletion in reach 13 in the updated simulation was lower during the summer months. The updated baseline withdrawals for the towns of Reading and Wilmington were used in all subsequent basin-scale simulations.

\section{Buildout Simulation}

Information from a state-wide buildout analysis conducted by the Massachusetts Executive Office of Energy and Environmental Affairs (EOEEA) in 2001 (Massachusetts Executive Office of Energy and Environmental Affairs, 2008) was used to simulate the effects of potential future development (also referred to as buildout) on streamflow in the Ipswich River Basin. The main objective of this analysis was to simulate the effects of potential future development when it takes place as conventional land-use change (that is, LID practices were not applied to the new development). Because simulating buildout involved converting an undeveloped HRU (for example, forest overlying till) to a developed HRU (for example, low-density residential development overlying till), the simulated effects of land-use change resulting 
from development were determined by the parameterization and consequent precipitation-runoff response of the modelcalibrated HRUs.

The buildout analysis shows how a community might develop if all remaining developable areas were fully built out in accordance with current local zoning codes (Massachusetts Executive Office of Energy and Environmental Affairs, 2008). Land that is not considered developable includes permanently protected open space, such as conservation land and riparian buffers, open water, and land that is already developed; for this study, forested and non-forested wetlands also are considered unavailable for development. The drainage area upstream from the South Middleton streamgage is relatively urban and contains less developable land than other parts of the basin. On a subbasin scale, drainage areas to reaches $27,28,31$, and 35 have the highest percentages of developable land (35 to 50 percent) in the basin (fig. 51).

To simulate the effects of potential future development on streamflow, a new land-use data layer was created by combining the EOEEA buildout information with the 1991 land-use data used to develop the original baseline model. To develop a new land-use data layer, the zoning codes in the developable areas were related to the land-use categories used for model HRU development (table 10). Using 1991 land use as a baseline, the buildout analysis indicated that about 17 percent of the entire Ipswich River Basin was developable (fig. 51). The major change in the basin was the loss of forest and gain of low-density residential development (fig. 52; table 11). Forest cover decreased from 38.6 percent in 1991 to 24.2 percent at buildout, and low-density residential development increased from 15.2 to 31.4 percent. Other developed land-use categories, including high-density residential and commercial, increased slightly at buildout.

After modifying the land-use data layer, the areas of HRUs for 1991 land use were modified to represent HRUs at buildout. All other aspects of the updated baseline model, such as parameter values, updated water withdrawals, and the amount of residential area using public water and on-site septic systems (PERLNDs 4, 6, 11, and 13), were held constant. To isolate the effects of land-use change on streamflow, results from a long-term simulation incorporating land use at buildout were compared to the results from the updated baseline simulation (LID-LT_upDem) incorporating 1991 land use; the only difference between these two simulations is the land-use data layer used to compute the HRUs in the basin.

The original intent was to simulate buildout with conventional development and LID to determine the extent to which buildout with LID practices reduced streamflow alteration

Table 10. Regionalized zoning codes for developable areas grouped by land-use categories used to construct the land use at buildout data layer for the Hydrological Simulation Program-FORTRAN model.

[Letters and numbers in parentheses represent abbreviations and codes; >, greater than; sq. ft., square feet]

\begin{tabular}{|c|c|}
\hline Regionalized zoning codes & Land-use categories \\
\hline Limited business (LB) & Commercial-industrial-transportation \\
\hline \multicolumn{2}{|l|}{ General business (GB) } \\
\hline \multicolumn{2}{|l|}{ Central business (CB) } \\
\hline \multicolumn{2}{|l|}{ Highway business (HB) } \\
\hline \multicolumn{2}{|l|}{ Office park (OP) } \\
\hline \multicolumn{2}{|l|}{ Mixed use (MU) } \\
\hline \multicolumn{2}{|l|}{ Light industrial (LI) } \\
\hline \multicolumn{2}{|l|}{ General Industrial (GI) } \\
\hline \multicolumn{2}{|l|}{ Institutional (IN) } \\
\hline \multicolumn{2}{|l|}{ Health care $(\mathrm{HC})$} \\
\hline Multifamily, medium density (MM) & High-density residential \\
\hline \multicolumn{2}{|l|}{ Multifamily, low density (ML) } \\
\hline \multicolumn{2}{|l|}{ Residential, 5,000-15,000 sq. ft. (R5) } \\
\hline \multicolumn{2}{|l|}{ Residential, $15,000-20,000$ sq. ft. (R4) } \\
\hline Residential, 20,000-40,000 sq. ft. (R3) & Low-density residential \\
\hline \multicolumn{2}{|l|}{ Residential, 40,000-80,000 sq. ft. (R2) } \\
\hline \multicolumn{2}{|l|}{ Residential, $>80,000$ sq. ft. (R1) } \\
\hline Residential/agricultural, $>2$ acre (RA) & \\
\hline
\end{tabular}




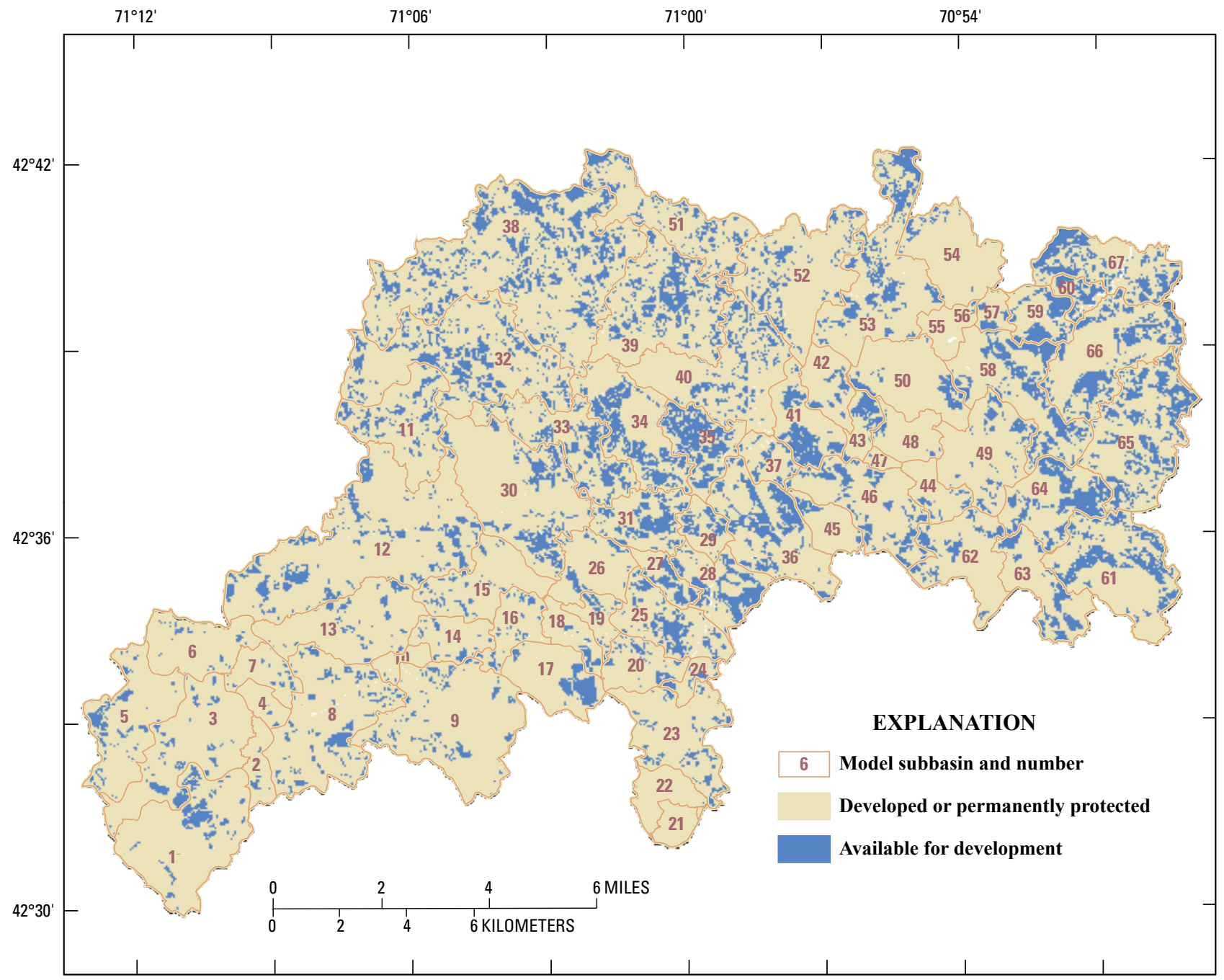

Base from U.S. Geological Survey digital data

Buildout information from Massachusetts Executive Office of Environmental Affairs, 2001

Massachusetts state plane projection, North American Datum of 1983

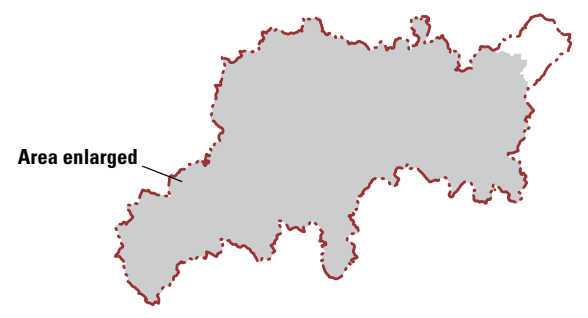

IPSWICH RIVER BASIN

Figure 51. Land potentially available for development in the Ipswich River Basin, MA, based on 1991 land use. 

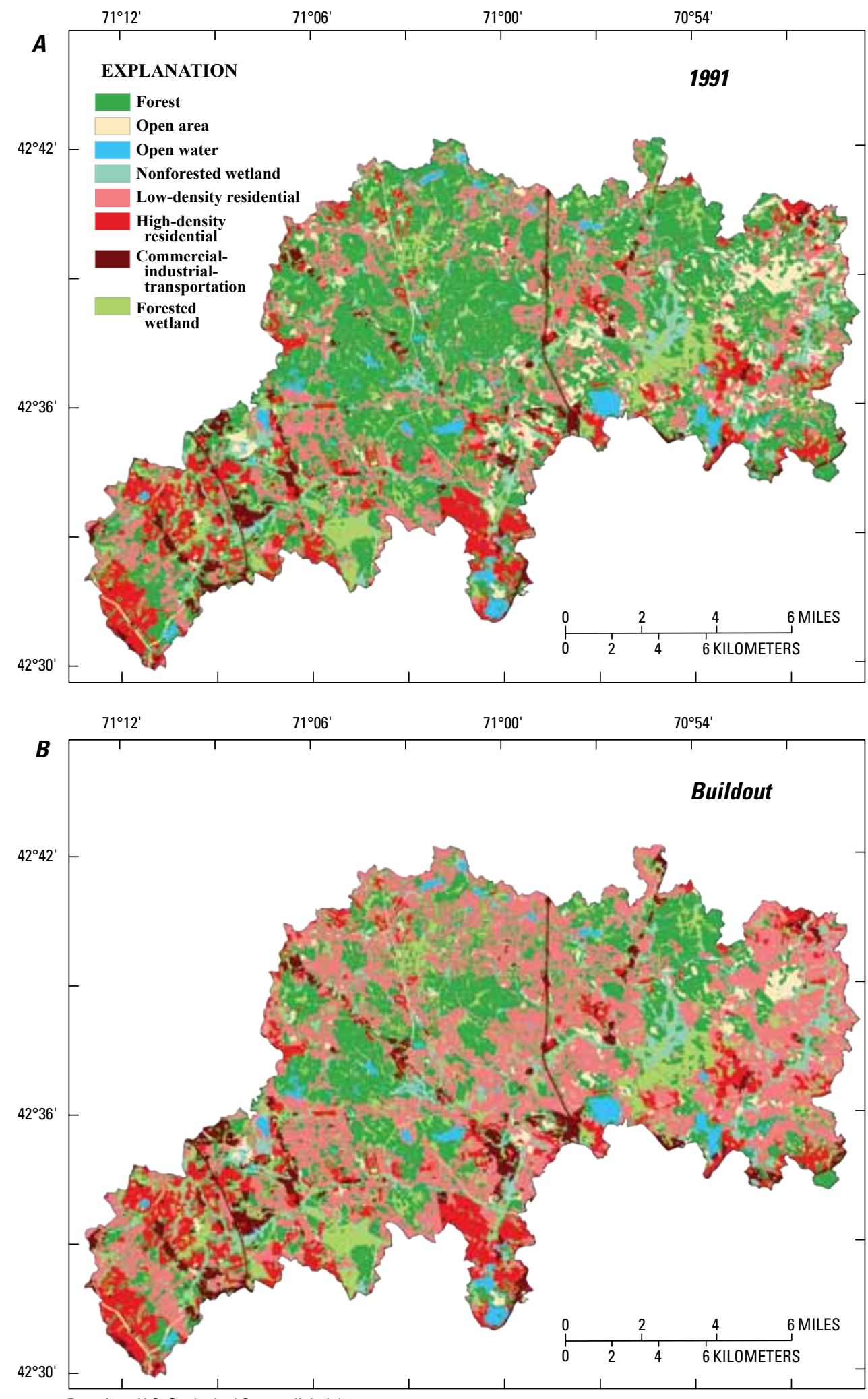

Base from U.S. Geological Survey digital data

Land-use data from Massachusetts GIS, 1991

Buidldout information from Massachusetts Executive Office of Environmental Affairs, 2001

Massachusetts state plane projection, North American Datum of 1983

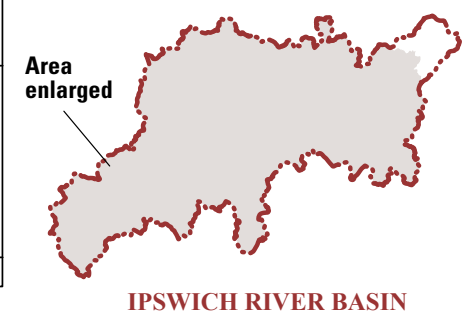

Figure 52. Generalized land use in the Ipswich River Basin, MA, $(A)$ in 1991 and $(B)$ at buildout. 
Table 11. Land use in 1991 and potential land use at buildout in the Ipswich River Basin, MA.

[Percent change expressed as area at buildout minus area in 1991 over area in 1991]

\begin{tabular}{|c|c|c|c|c|c|}
\hline \multirow[b]{2}{*}{ Land use description } & \multicolumn{2}{|c|}{1991 land use } & \multicolumn{2}{|c|}{ Buildout land use } & \multirow{2}{*}{$\begin{array}{c}\text { Percent } \\
\text { change }\end{array}$} \\
\hline & $\begin{array}{c}\text { Area } \\
\text { (acres) }\end{array}$ & $\begin{array}{l}\text { Percentage of } \\
\text { total area }\end{array}$ & $\begin{array}{c}\text { Area } \\
\text { (acres) }\end{array}$ & $\begin{array}{c}\text { Percentage of } \\
\text { total area }\end{array}$ & \\
\hline Open & $6,675.2$ & 7.0 & $3,407.0$ & 3.6 & -49.0 \\
\hline Open water & $2,384.4$ & 2.5 & $2,384.4$ & 2.5 & 0.0 \\
\hline Low-density residential & $14,471.3$ & 15.2 & $30,005.4$ & 31.4 & 107.3 \\
\hline High-density residential & $11,486.0$ & 12.0 & $11,696.3$ & 12.2 & 1.8 \\
\hline Commercial-industrial-transportation & $3,583.5$ & 3.8 & $4,847.7$ & 5.1 & 35.3 \\
\hline Forested wetland & $13,284.0$ & 13.9 & $13,284.0$ & 13.9 & 0.0 \\
\hline
\end{tabular}

relative to conventional buildout. However, because there was relatively little difference between streamflow for buildout using conventional development and streamflow using 1991 land use (discussed in the "Results and Discussion" section of this report), buildout incorporating LID practices, such as cluster development, was not evaluated in this study.

\section{Simulation of Low-Impact-Development Retrofits Upstream from the South Middleton Streamgage}

EIA upstream from the South Middleton streamgage was reduced by 50 percent as a surrogate for the implementation of LID practices that decrease EIA (for example, porous pavement, green roofs, and re-direction of surface runoff from some percentage of the EIA to natural or constructed recharge areas). In 1991 , about 42.5 percent of the 28,416 -acre $\left(44.4 \mathrm{mi}^{2}\right)$ drainage area to the South Middleton streamgage was developed land use (fig. 53). Of the 12,070 acres of developed land, 1,929 acres (16.0 percent of developed area and 6.8 percent of total area) were designated as IMPLNDs (Zarriello and Ries, 2000). EIA ranged from 1.6 percent (reach 4) to 21.9 percent (reach 2), with a median value of 5.9 percent for the 19 subbasins representing the area upstream from the South Middleton streamgage (fig. 54). A reduction of 50 percent, which would correspond to re-directing surface runoff from about 965 acres of highly discontinuous impervious surface with direct discharge to streams, was selected as a substantial, but reasonable, level of EIA reduction in the $44.4 \mathrm{mi}^{2}$ drainage area. Thus, this simulation was considered to represent widespread implementation of various LID practices achieved by retrofitting existing commercial, high-density residential, and low-density residential development. The response of simulated streamflow to a 50-percent reduction in EIA provided insight into the magnitude of response that could be expected from higher or lower percentage EIA reductions.
To simulate the LID retrofits using the HSPF model, the percentage of total area apportioned to IMPLNDs was reduced from 63 percent to 31.5 percent for commercial land use, 14 percent to 7 percent for high-density residential land use, and 2.5 percent to 1.25 percent for low-density residential land use. These changes resulted in a uniform 50-percent reduction in EIA while maintaining the spatial distribution of HRUs in the subbasins upstream from the South Middleton streamgage. To isolate the effects on streamflow of reducing EIA, the results of the long-term simulation incorporating reduced EIA was compared to the results of the updated baseline simulation (LID-LT_upDem); the only difference between these two simulations was the amount of EIA and associated pervious urban land use upstream from the South Middleton streamgage.

\section{Water Conservation Simulation}

Five water-conservation pilot projects were conducted in the Ipswich River Basin by MDCR, in collaboration with researchers at Tufts University. Results from the following four of the five pilot projects were used in the water-conservation simulation: (1) installation of weather-sensitive "smart" irrigation controller switches on automated sprinkler systems at municipal athletic fields; (2) application of soil amendments at a municipal athletic field to improve soil moisture and nutrient retention; (3) installation of 800-gallon rainwater harvesting systems for the collection and reuse of rainwater for irrigation; and (4) implementation of two concurrent municipal programs offering homeowners free indoor water-use audits, water-reducing retrofit kits, and rebates for low-flow toilets and washing machines. Features in the first three of these pilot projects were designed to reduce irrigation demands that affect summer withdrawals in the basin, and the fourth was designed to reduce indoor water use that affects withdrawals year round. 


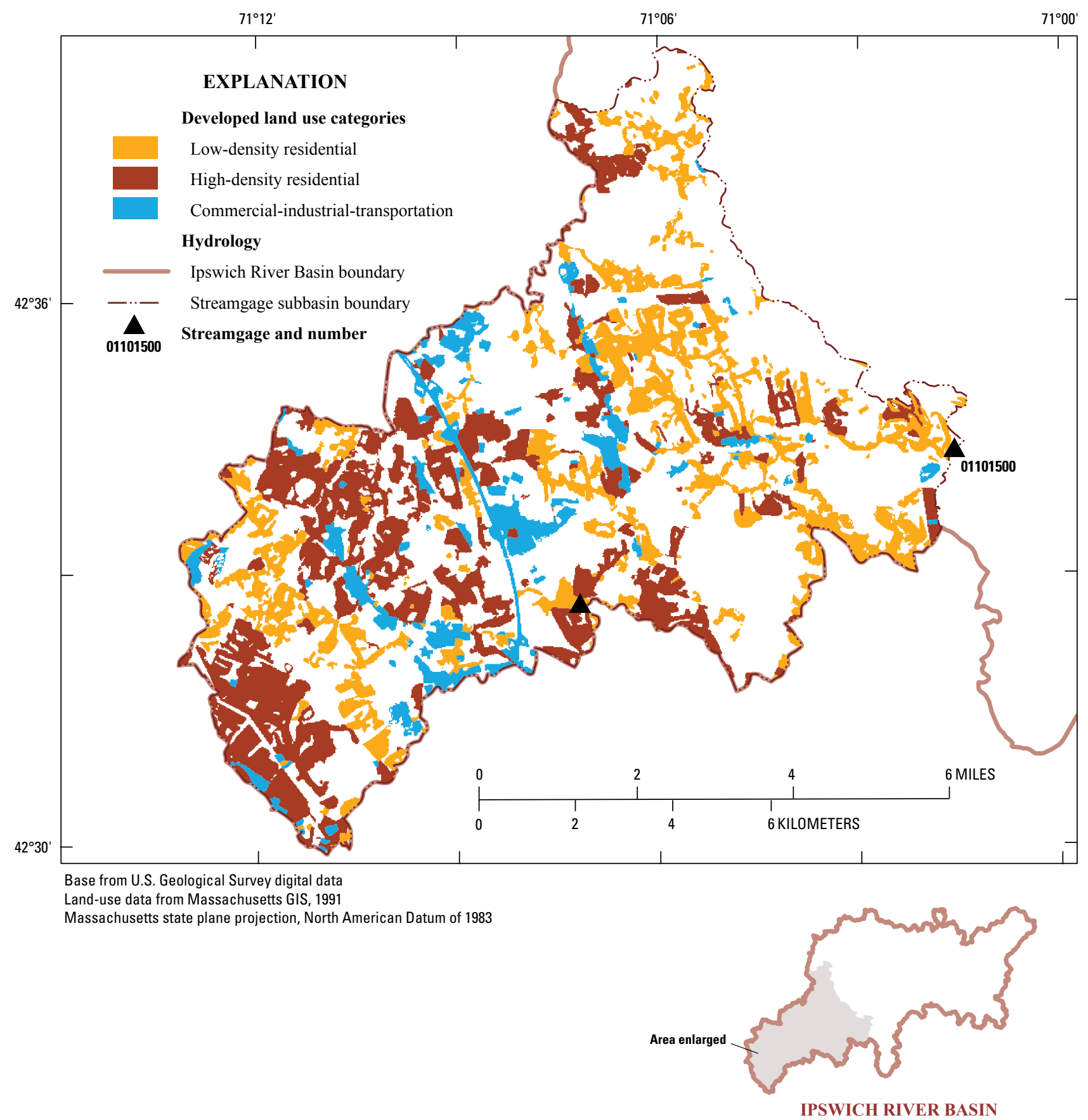

Figure 53. Commercial, high-density residential, and low-density residential land use in 1991 for the drainage area to the South Middleton streamgage, Ipswich, MA. 


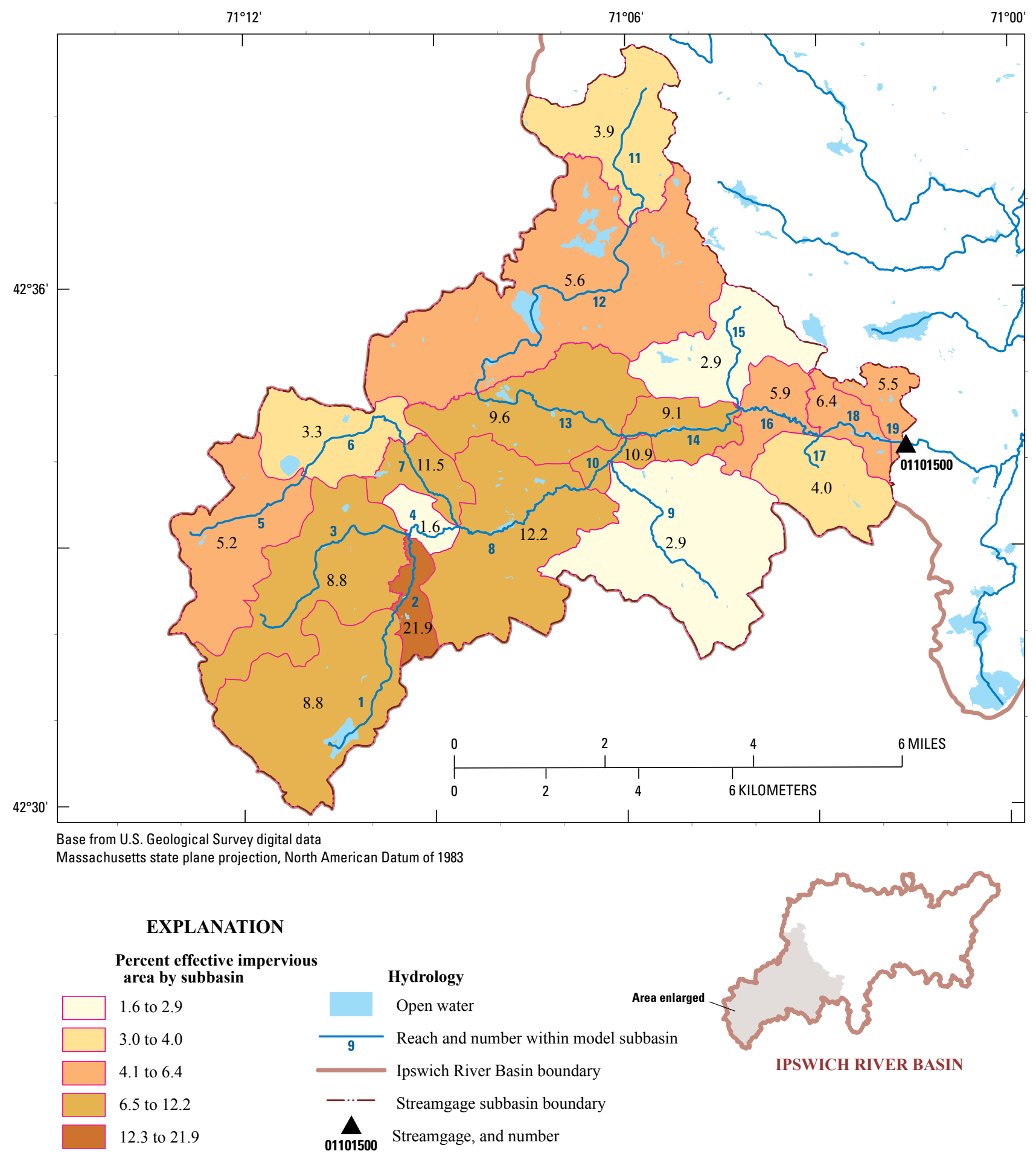

Figure 54. Percent effective impervious area, by subbasin (1991 land use), for subbasins upstream from the South Middleton streamgage, Ipswich, MA. 
To simulate the hydrologic effects of basin-wide application of the water-conservation pilot projects, MDCR estimated hypothetical reductions in monthly withdrawals for each town that withdraws water from the basin (as represented by the withdrawals in the updated baseline simulation). Reductions were calculated by MDCR by scaling up the water-use reductions computed for each pilot project using the appropriate data for each town (for example, the number of acres of athletic field irrigated with water withdrawn from the basin, the number of single-family homes, and the total number of households). Details of the calculations and assumptions used by MDCR to scale up the data from the pilot-scale water conservation programs to the town level are provided in tables 1-1 and 1-2 in Appendix 1. Although some reductions would only occur seasonally (irrigation demands), reductions were applied year round to simulate the effects of a best-case reduction in water use. Water-use reductions ranged from about 0.27 million gallons per month (Mgal/month) for the town of Ipswich to $4.43 \mathrm{Mgal} / \mathrm{month}$ for the Salem-Beverly water-supply system, which correspond to 3.3 and 1.4 percent of average 1989-1993 withdrawal rates, respectively, for these communities (table 12). The largest percentage reductions were for the town of Hamilton (8.5 percent of average 1989-1993 withdrawals).

Monthly water-use reductions were converted to daily rates and then used to adjust the updated baseline simulation withdrawals by use of multiplication factors. To compute the multiplication factors, the average streamflow-depletion rate or direct surface-water withdrawal rate, as appropriate, (collectively referred to as withdrawals in this section) was computed for each source for the period 1989 to 1993 (with the exception of the Reading and Wilmington withdrawals, for which the updated withdrawals were used). Sources were then grouped by town, and a total average withdrawal rate for each town was calculated (table 12). The multiplication factor for each town was then computed as one minus the ratio of the average water savings rate to the total average updated baseline withdrawal rate (data not shown). This multiplication factor was then applied to the withdrawal time series for each source, resulting in reductions proportional to average updated baseline withdrawals. Long-term time series for 1961 to 1995 then were computed as described in the "Model Description" section of the report, and withdrawals were regrouped and totaled by subbasin. To isolate the effects of the reductions from the scaled up water-conservation pilot projects, the long-term simulation with reduced withdrawals (LID_LT_conserv) was compared to the updated baseline simulation (LID-LT_upDem); the only differences between these two simulations were the withdrawal rates.

\section{Local-Scale Simulations}

At the scale of model subbasins (hundreds to thousands of acres), drainage areas in the Ipswich River Basin are characterized as a heterogeneous mixture of land use and surficial geology. As indicated by the results from the basin-scale simulations (discussed below), the percentage of urban land use generally was found to be too low to induce large changes in simulated streamflow in response to reducing EIA to represent LID practices. On smaller spatial scales, however, larger percentages of drainage areas are likely to be developed (in the Ipswich River Basin and elsewhere), and LID could be implemented in the developed areas, with a resulting larger effect on flow in small streams. To address this issue of spatial scale, hypothetical local-scale simulations were conducted to show the potential effects of land-use change, surficial geology, and management practices on a local scale (100 acres). By simulating streamflow on a local scale, effects that may not be evident on the subbasin scale, such as responses to land-use change and development patterns, were evaluated. Consequently, simulations at this scale provided a better understanding of the geologic and land-use settings for which LID may have the greatest potential benefits. Similar to the basin-scale simulations, reduced EIA was used as a surrogate measure of the net effect of specific LID practices.

To conduct the local-scale simulations with the calibrated HSPF model, selected existing HRUs were re-scaled to 100 acres to simulate runoff from small drainage areas with uniform land use. Although drainage areas in eastern Massachusetts smaller than about $1 \mathrm{mi}^{2}$ (640 acres) have a low probability of producing perennial streamflow (Bent and Steeves, 2006), the model is capable of simulating continuous runoff from 100-acre parcels (at low flows below measureable values); consequently, it was possible to compare differences in simulated flows to evaluate local-scale effects. Streamflow was simulated as total surface runoff, interflow, and base flow from the parcel (that is, there was no spatially variable flow to a channel adjacent to the parcel). As in the basin-scale simulations, EIA represented the fraction of the total impervious area from which precipitation discharged directly to streams with no infiltration. Runoff from the remaining impervious surfaces within the pervious areas (noneffective impervious surface (NEIA)) was assumed to discharge directly to ground surface; stormwater-control structures for the NEIA, such as detention basins, were not explicitly represented in the model. Simulations were conducted for conventional development and cluster development scenarios.

\section{Conventional Development}

A set of simulations was conducted to evaluate the effects of uniform land-use change on streamflow. One example of such a change was the conversion of 100 acres of forest to a commercial development. Simulations also were conducted to evaluate the sensitivity of streamflow to the amount of EIA associated with developed land use. In this study, conventional development refers to development consisting of uniform lot sizes with no preservation of open space. In the Ipswich River Basin HSPF model, high-density residential areas contain lot sizes of less than or equal to 0.5 acre, whereas low-density residential areas contain lot sizes of greater than 0.5 acre (Zarriello and Ries, 2000). Therefore, representative housing 

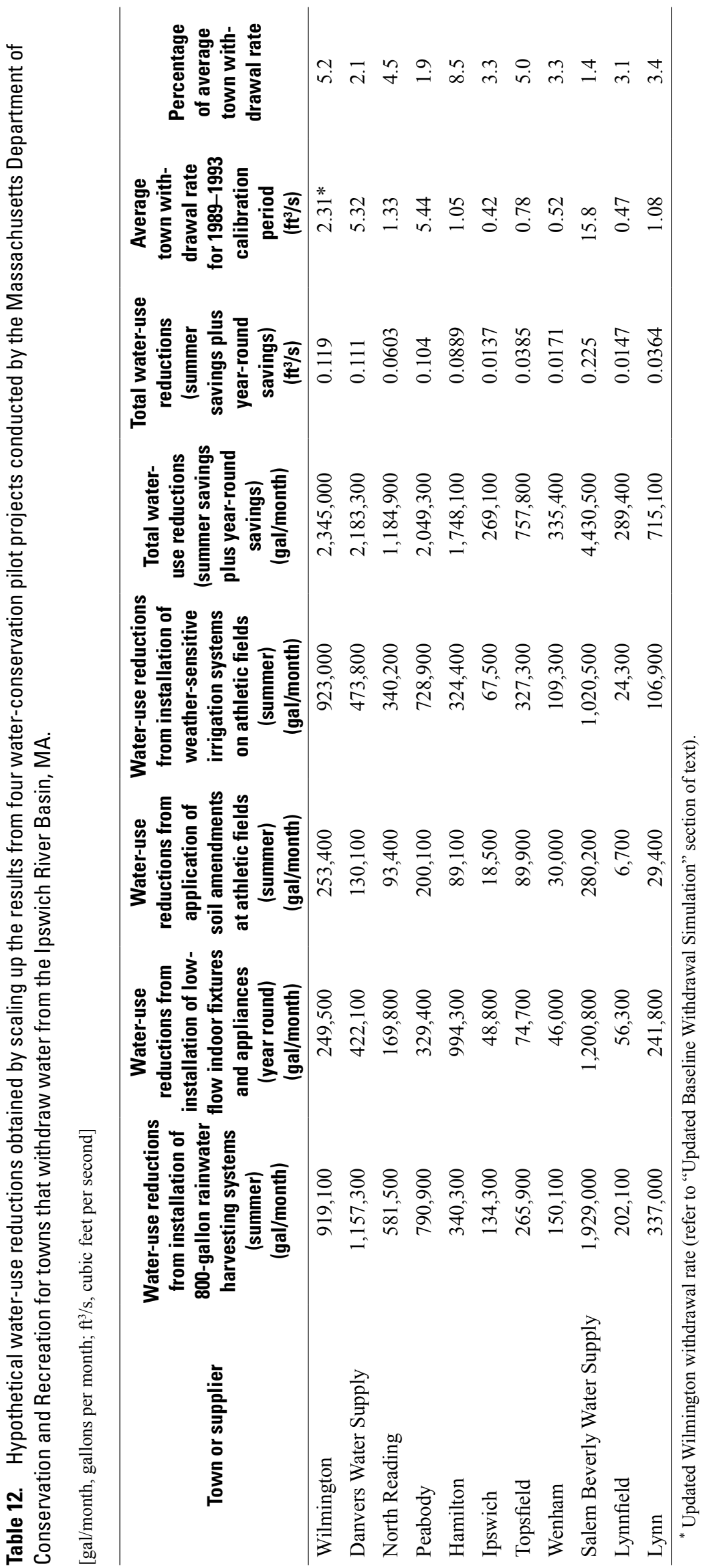
densities would be about 400 houses on 100 acres (1/4-acre lots) for conventional high-density residential development and about 100 houses on 100 acres (1-acre lots) for low-density residential development.

Four land-use types were defined for the local-scale scenario. Within each land-use type, additional simulations were made at the local scale to represent various combinations of EIA, NEIA, and pervious areas overlying surficial geology types (table 13).

1. Forested (undeveloped) land use (no EIA).

2. Commercial land use. One simulation was conducted with the model-calibrated EIA for commercial land use of 63 percent. Thus, 100 acres of commercial development were represented by 37 acres of the pervious commercial HRU and 63 acres of EIA. Two additional simulations were conducted to evaluate the effects of varying EIA. The model-calibrated EIA was reduced by 25 and 50 percent (to 47 acres and 31.5 acres, respectively) to simulate the hydrologic effects of incorporating LID practices that reduce EIA. The model variables for the pervious commercial HRU were adjusted slightly during calibration to respond faster to precipitation than otherwise would be the case based only on underlying geology to account for NEIA that contributed water to the pervious area and for disturbances to the underlying soil from compaction and land filling (Zarriello and Ries, 2000). However, because the commercial HRU was not differentiated by underlying geology (commercial areas overlying till and sand and gravel were grouped into a single HRU), and because most of the commercial land use in the basin overlies sand and gravel, calibrated parameter values for the pervious commercial HRU allowed more infiltration and less interflow and surface runoff than the residential HRUs overlying till, which represented the least pervious PERLNDs in the model.

3. High-density residential land use. One simulation was conducted with the model-calibrated EIA for high-density residential land use of 14 percent. Thus, 100 acres of high-density residential development were represented by 86 acres of the high-density residential HRU (overlying till or sand and gravel) and 14 acres of EIA. Two additional simulations were conducted to evaluate the effect of varying EIA. The model-calibrated EIA (14 acres) was reduced by 50 percent (to 7 acres) to evaluate the effects of implementing LID to reduce EIA and increased by 100 percent (to 28 acres) to simulate a reasonable upper boundary for EIA in high-density residential areas (Alley and Veenhuis, 1983). An EIA higher than the model-calibrated value could be representative of local conditions in the basin. Similar to the model variables for the pervious commercial HRU, model variables for the pervious highdensity residential HRUs were adjusted slightly during calibration to account for NEIA and disturbance of the soil, but after adjustment the model variables more closely represented the characteristics of undisturbed soil than disturbed soil.

4. Low-density residential land use. One simulation was conducted with the model-calibrated EIA for low-density residential land use of 2.5 percent. Thus, 100 acres of low-density residential development were represented by 97.5 pervious acres of the low-density residential HRU (overlying till or sand and gravel) and 2.5 acres of EIA. As above, two additional simulations were conducted to evaluate the effect of varying EIA. The model-calibrated EIA ( 2.5 acres) was reduced by 50 percent (to 1.25 acres) to simulate the effects of implementing LID to reduce EIA, and increased by 100 percent (to 5 acres) to simulate a reasonable upper boundary for EIA in low-density residential areas (Alley and Veenhuis, 1983). As for high-density residential land use, an EIA higher than the model-calibrated value for low-density residential land use could be representative of local conditions in the basin. The model variables for the pervious low-density residential HRUs were adjusted the least during calibration to account for NEIA and disturbance of the soil, and thus were most representative of the undisturbed soil. Because the percentage of imperviousness associated with low-density residential development is low, EIA changes can be expected to have minor effects on simulated streamflow; however, the simulation was conducted to show the types of development for which implementation of LID techniques would likely have the largest and smallest hydrologic effects.

\section{Cluster Development}

Simulations were conducted to evaluate the effects of high- and low-density residential clustered-housing practices, with and without LID features, on streamflow (table 13). Cluster developments preserve open, undeveloped space and potentially reduce the overall amount of EIA compared to conventional developments. To simulate clustering, the 100-acre parcel was divided into an undeveloped (forested) part and a developed part containing the houses. Forested HRUs were used to represent the undeveloped part of the parcel because most developable areas in the basin were forested at the time of the study. Additional simulations were conducted to evaluate the effects of varying the amount of EIA in the developed part of the parcel.

\section{Clustering Practices for High-Density Residential Development}

Housing for a conventional 100-acre high-density residential development (400 houses on 1/4-acre lots) was clustered onto 40 acres (400 houses on 0.1 -acre lots) of the 100 -acre parcel to evaluate the effects of open-space preservation for a high-density residential development. The remaining 60 acres were assumed to be forested. The spatial distribution of runoff from the 100-acre parcel was not represented in the model. 
Table 13. Land-use distribution used in local-scale simulations for 100-acre parcels, conducted with the calibrated Hydrological Simulation Program-FORTRAN model of the Ipswich River Basin, MA.

[EIA, effective impervious area; SG, sand and gravel; \%, percent; HRU, hydrologic response unit; 1-d res, pervious low-density residential area; h-d res, pervious high-density residential area; In contrast to forested and residential HRUs, the pervious commercial HRU is not differentiated by underlying surfical geology]

\begin{tabular}{lcc}
\hline \multicolumn{1}{c}{ Simulation (LID_LT-Iocal) description } & $\begin{array}{c}\text { Percent } \\
\text { EIA }\end{array}$ & Land-use distribution \\
& Undeveloped \\
\hline Forest over SG & 0 & 100 acres forest over SG \\
Forest over till & 0 & 100 acres forest over till
\end{tabular}

\begin{tabular}{|c|c|c|}
\hline \multicolumn{3}{|c|}{ Conventionally laid out (uniform) development } \\
\hline Commercial, $25 \%$ reduction in EIA & 47 & 53 acres commercial; 47 acres EIA \\
\hline High-density residential over SG, model-calibrated EIA & 14 & 86 acres h-d res over SG; 14 acres EIA \\
\hline High-density residential over SG, $50 \%$ decrease in EIA & 7 & 93 acres h-d res over SG; 7 acres EIA \\
\hline Low-density residential over SG, model-calibrated EIA & 2.5 & 97.5 acres 1 -d res over $\mathrm{SG} ; 2.5$ acres EIA \\
\hline Low-density residential over SG, $50 \%$ decrease in EIA & 1.25 & 98.75 acres $1-d$ res over SG; 1.25 acres EIA \\
\hline Low-density residential over SG, $100 \%$ increase in EIA & 5 & 95 acres $1-d$ res over SG; 5 acres EIA \\
\hline Low-density residential over till, model-calibrated EIA & 2.5 & 97.5 acres $1-\mathrm{d}$ res over $\mathrm{SG} ; 2.5$ acres EIA \\
\hline Low-density residential over till, $50 \%$ decrease in EIA & 1.25 & 98.75 acres $1-d$ res over SG; 1.25 acres EIA \\
\hline Low-density residential over till, $100 \%$ increase in EIA & 5 & 95 acres $1-d$ res over SG; 5 acres EIA \\
\hline
\end{tabular}

Low-density residential over till, 100\% increase in EIA
Cluster development ${ }^{1}$

High-density residential over SG, 14\% EIA in developed area

High-density residential over SG, 28\% EIA in developed area

High-density residential over SG, 56\% EIA in developed area

Low-density residential over SG, 7\% EIA in developed area Low-density residential over SG, 14\% EIA in developed area Low-density residential over SG, 28\% EIA in developed area

High-density residential over till, 14\% EIA in developed area High-density residential over till, 28\% EIA in developed area High-density residential over till, 56\% EIA in developed area

5.6

11.2 60 acres forest over SG; 34.4 acres commercial; 5.6 acres EIA

22.4

7.0

11.2

22.4

Low-density residential over till, 7\% EIA in developed area Low-density residential over till, 14\% EIA in developed area Low-density residential over till, 28\% EIA in developed area
1.8

3.5

5.6

60 acres forest over SG; 28.8 acres commercial; 11.2 acres EIA 60 acres forest over SG; 17.6 acres commercial; 22.4 acres EIA

75 acres forest over SG; 23.5 acres h-d res over SG; 1.8 acres EIA 75 acres forest over SG; 21.5 acres h-d res over SG; 3.5 acres EIA 75 acres forest over SG; 18.0 acres h-d res over SG; 7.0 acres EIA

1.875 acres forest over SG; 23.5 acres h-d res over SG; 1.8 acres EIA

3.5 75 acres forest over SG; 21.5 acres h-d res over SG; 3.5 acres EIA 7.075 acres forest over SG; 18.0 acres h-d res over SG; 7.0 acres EIA

\footnotetext{
${ }^{1}$ The low-density cluster development was represented by the high-density residential HRU.
} 
For each surficial geology type, three simulations were conducted to simulate a reasonable range of EIA for the 40 -acre developed part of the parcel: 56 percent (22.4 acres) EIA, 28 percent (11.2 acres) EIA, and 14 percent (5.6 acres) EIA, leaving 17.6, 28.8, and 34.4 acres, respectively, as pervious area in the developed part of the parcel. The spread in EIA values represents a reasonable range for high-density residential development on 0.1-acre lots, with 28 percent representing a typical value (Alley and Veenhuis, 1983), 56 percent representing a potential upper boundary (Alley and Veenhuis, 1983), and 14 percent representing a potential lower boundary if LID practices such as porous pavement were applied to the development. Despite reducing lot sizes to 0.1 acre, the pervious areas in the developed part of the parcel still were represented by the high-density residential HRUs because, of all the HRUs in the Ipswich River Basin HSPF model, the high-density residential HRUs best represent the intensity of residential development. The 60-acre undeveloped part of the parcel, represented by the forested HRUs, remained unchanged for all simulations.

\section{Clustering Practices for Low-Density Residential Development}

Housing for a conventional 100-acre low-density residential development (100 houses on 1-acre lots) was clustered onto 25 acres ( 100 houses on 0.25 acre lots) of the 100 -acre parcel to evaluate the effects of open-space preservation for a low-density residential development. The remaining 75 acres were assumed to be forested. The spatial distribution of runoff from the 100-acre parcel was not represented in the model.

For each surficial geology type, three simulations were conducted to simulate a reasonable range of EIA values for the 25-acre developed part of the parcel: 28 percent ( 7.0 acres) EIA, 14 percent ( 3.5 acres) EIA, and 7 percent ( 1.8 acres) EIA, leaving 18.0 acres, 21.5 acres, and 23.2 acres, respectively, as pervious area in the developed part of the parcel. The spread in EIA values represents a reasonable range for highdensity residential development on $1 / 4$-acre lots, with 14 percent representing the model-calibrated value for high-density residential development, 28 percent representing a potential upper boundary (Alley and Veenhuis, 1983), and 7 percent representing a potential lower boundary if LID practices such as porous pavement were applied to the development. The pervious area in the developed part of the parcel was represented by the high-density residential HRU, rather than the lowdensity residential HRU, because the high-density residential HRU parameter values better represent the higher density of development (1/4-acre lots). The 75 -acre undeveloped part of the parcel, represented by the forested HRUs, remained unchanged for all of the simulations.

\section{Effects of Water-Withdrawal Changes and Low- Impact-Development Practices on Streamflow}

The effects of water-withdrawal changes and LID practices on streamflow were evaluated by comparing two or more scenarios at selected locations in the basin to each other; thus, relative rather than absolute changes in simulated streamflow were the focus of the assessment.

\section{Basin-Scale Simulations}

The reaches selected for analysis generally were chosen to show the maximum effect of a land-use or water-use change on an individual reach (for example, reach 27 with a direct drainage area of $0.66 \mathrm{mi}^{2}$ ) or the integrated effect of a change over a larger area (for example, reach 19 with a total drainage area of $\left.44.4 \mathrm{mi}^{2}\right)$.

\section{Updated Baseline Simulation}

The updated withdrawals for the towns of Reading and Wilmington generally led to substantially higher low and medium simulated flows in the reaches upstream from and at the South Middleton streamgage (fig. 55; table 14). Reducing ground-water withdrawals from the upper basin had a greater effect on simulated flows than any of the LID practices discussed in the following sections. Flow-duration plots from long-term simulations show that differences are evident for flows greater than the 30 percent exceedance probability at most locations (fig. 55). The largest increases in low flows occurred in reach 1 (Maple Meadow Brook at Route 38, Wilmington) and reach 8 (Ipswich River at Mill Street, near Reading) because multiple wells were taken out of service. Streamflow depletion rates fell to zero in headwater reach 1 and to nearly zero in reach 8 , causing the updated-baseline simulation flows to nearly equal the no-withdrawal-simulation flows (figs. 55A, B).

August median flows (median of August median flows for the period 1961-1995) rose from 0 to $1.34 \mathrm{ft}^{3} / \mathrm{s}$ in reach 1 and from 0.539 to $6.12 \mathrm{ft}^{3} / \mathrm{s}$ in reach 8 . Similarly, median 1-day, 7-day, and 30-day low flows rose from no-flow conditions to flows similar to the no-withdrawal simulation. Changes in withdrawal patterns and effects on flow are less pronounced in reach 5 (Lubbers Brook above Route 38, Wilmington) and reach 13 (Martins Brook above mouth, North Reading) (figs. 55C, D). For example, August median flows rose from 0.917 to $1.01 \mathrm{ft}^{3} / \mathrm{s}$ in reach 5 (about 10 percent) and from 0.032 to $0.274 \mathrm{ft}^{3} / \mathrm{s}$ in reach 13 (about 756 percent).

The combined changes in withdrawal patterns upstream from reach 19 (Ipswich River at South Middleton streamgage) led to substantially increased low and median flows in the Ipswich River at this location (fig. 55E). Total withdrawals upstream from reach 19 averaged $6.7 \mathrm{Mgal} / \mathrm{d}$ in the original baseline simulation and $3.5 \mathrm{Mgal} / \mathrm{d}$ in the updated baseline simulation. The original baseline model simulated August median flow was $3.42 \mathrm{ft}^{3} / \mathrm{s}$, the median 1-day low flow was $0.740 \mathrm{ft}^{3} / \mathrm{s}$, and the median 7-day low flow was $0.983 \mathrm{ft}^{3} / \mathrm{s}$. The updated baseline model simulated August median flow was $8.36 \mathrm{ft}^{3} / \mathrm{s}$, the median 1-day low flow was $2.80 \mathrm{ft}^{3} / \mathrm{s}$, and the median 7-day low flow was $3.65 \mathrm{ft}^{3} / \mathrm{s}$. Thus, the August 

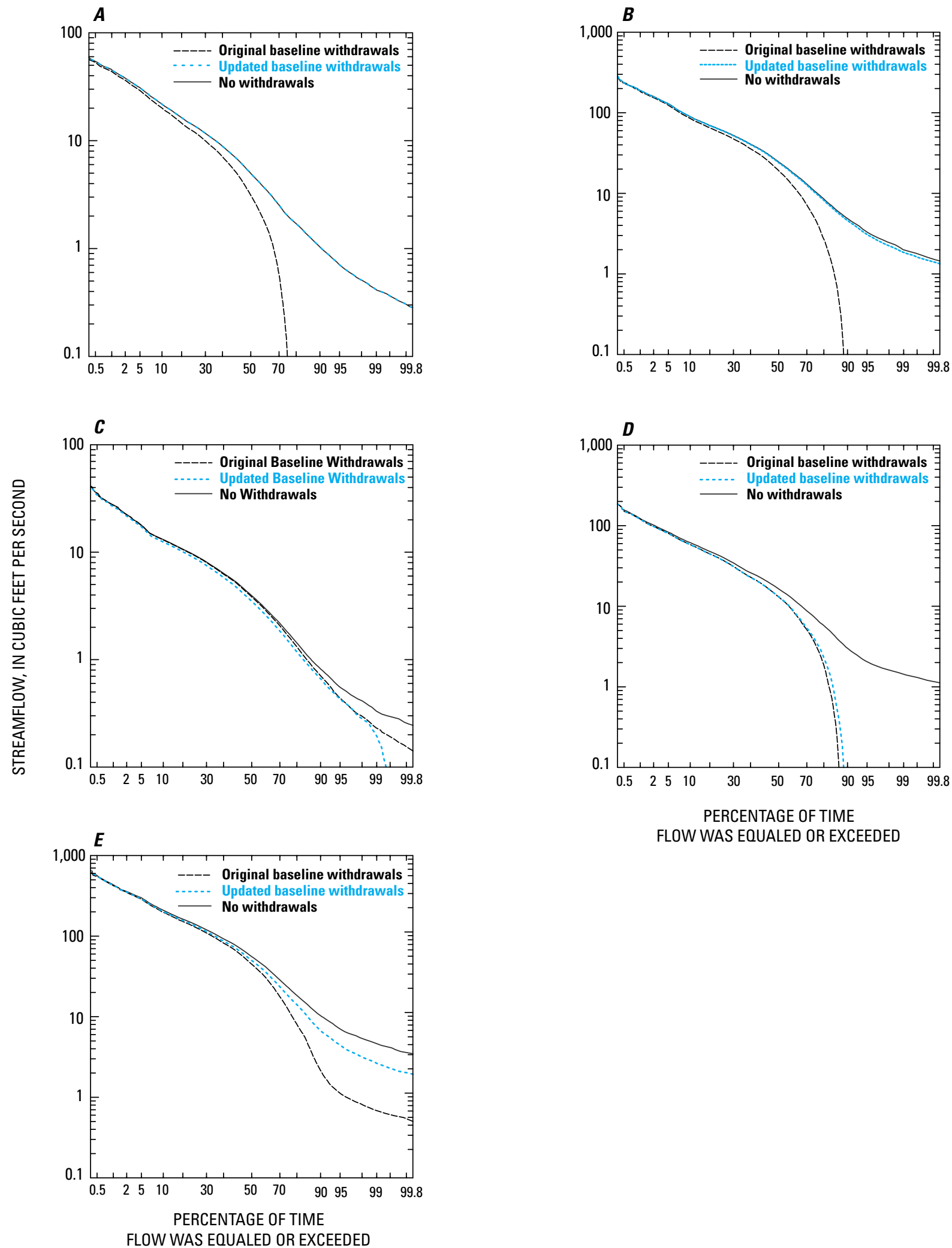

FLOW WAS EQUALED OR EXCEEDED

Figure 55. Flow-duration curves of daily mean streamflow at $(A)$ reach 1, Maple Meadow Brook at Route 38, Wilmington, $(B)$ reach 8, Ipswich River at Mill Street near Reading, $(C)$ reach 5, Lubbers Brook above Route 38, Wilmington, $(D)$ reach 13, Martins Brook above mouth, North Reading, and $(E)$ reach 19, Ipswich River at South Middleton streamgage in the Ipswich River Basin developed from long-term (1961-1995) simulations with 1989-1993 withdrawals (original baseline withdrawals), updated withdrawals for the towns of Reading and Wilmington (updated baseline withdrawals), and no withdrawals. Reach locations are shown in fig. 49. 


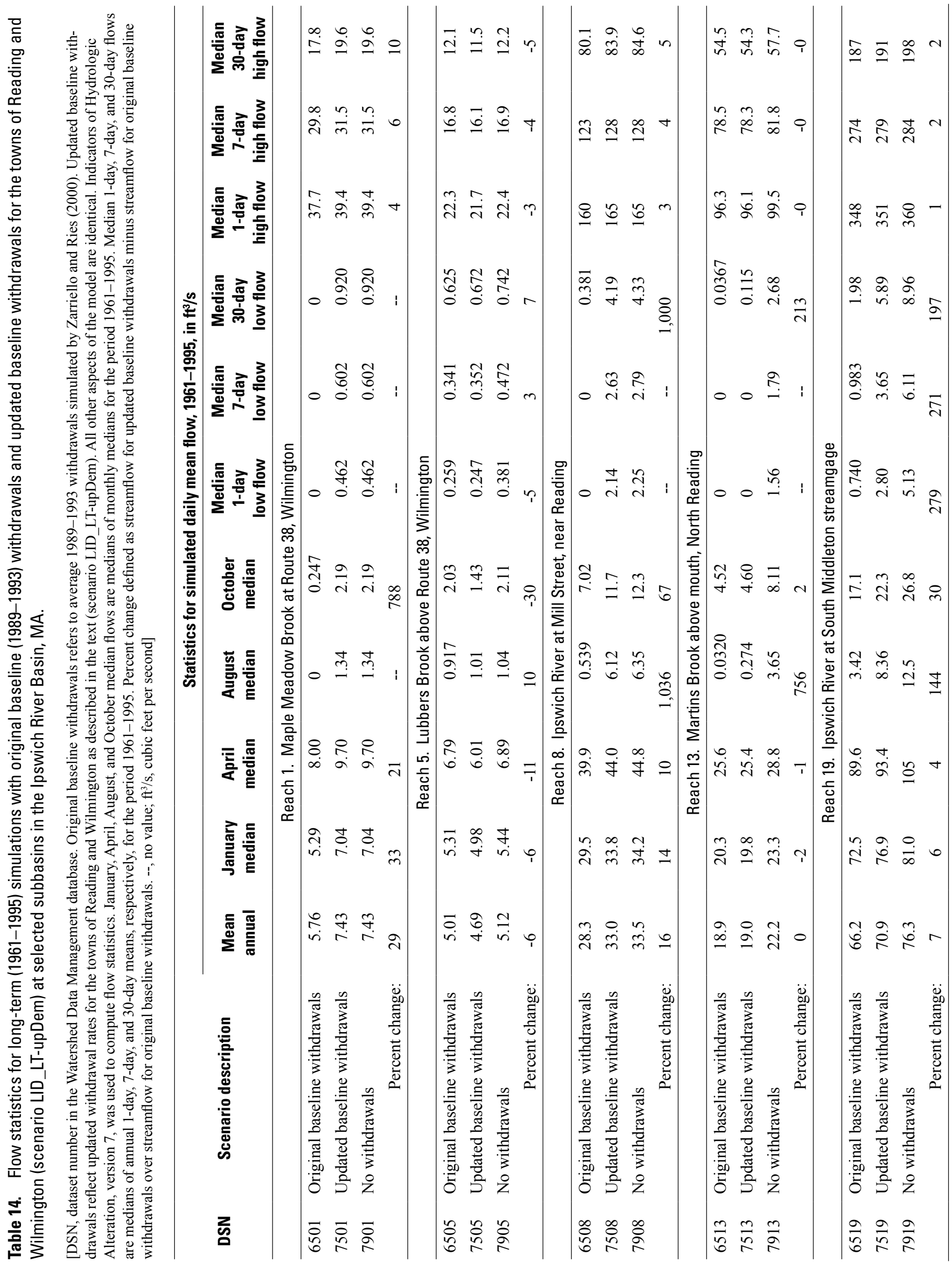


median flow rose 144 percent, the median 1-day low flow rose 279 percent, and the median 7-day low flow rose 271 percent.

Current and anticipated reductions in water withdrawals for the towns of Reading and Wilmington have the largest effects on simulated flows in the upper Ipswich River and Maple Meadow Brook, and more modest effects on simulated flows in Lubbers Brook and Martins Brook. Local effects on small streams in the immediate vicinity of withdrawal wells could be more pronounced, but these effects were not specifically evaluated with the model.

\section{Buildout Simulation}

Land-use change associated with buildout generally had minor effects on simulated streamflow in the Ipswich River Basin. Flow-duration plots were compared with the updated baseline simulation (1991 land use). These plots (fig. 56) show (1) long-term buildout simulation results for one reach with a percentage of developable area in its drainage area similar to the basin average percentage (reach 34, Boston Brook above mouth, Middleton), (2) three reaches with greater than average percentages of developable area (reach 35, Ipswich River above Nichols Brook, Middleton; reach 28, Ipswich River at Maple Street, Middleton; reach 27, Middleton Pond Brook, Middleton), and (3) two reaches that show the effects of land-use change over large drainage areas (reach 19, Ipswich River at South Middleton streamgage; reach 56, Ipswich River at Ipswich streamgage). The total drainage areas to reaches 19 and 56 are 44.4 and $125 \mathrm{mi}^{2}$, respectively. For the three reaches with large percentages of developable area, upstream flows were omitted so that the effects of land-use change in the direct drainage area (that is, the subbasin area) that contributes streamflow to the reach could be evaluated.

In reach 34 , about 24.5 percent $(1,713$ acres $)$ of the 6,980-acre $\left(10.9 \mathrm{mi}^{2}\right)$ drainage area to Boston Brook was developable. Of the 1,713 developable acres, only 106 acres was apportioned to IMPLNDs because most of the developable land was zoned for low-density residential development. The EIA in the drainage area increased from 2.7 percent in 1991 to 4.2 percent at buildout. These land-use changes had modest effects on streamflow in Boston Brook (fig. 56A; table 15). For example, the median 1-day high flow (annual flood flow) increased only about 13 percent from 104 to $118 \mathrm{ft}^{3} / \mathrm{s}$, and the median August flow and other low-flow statistics increased by less than 5 percent.

In reach 35 , about 52 percent (512 acres) of the 989 -acre subbasin area was developable, of which only 13 acres (2.5 percent of the developable area) was apportioned to IMPLNDs because most of the developable area is zoned for low-density residential development. Thus, the EIA in the direct drainage area to reach 35 increased from 1.9 percent in 1991 to 3.2 percent at buildout. Consequently, although almost 52 percent of the subbasin was developable, land-use changes due to buildout had modest effects on streamflow (fig. 56B) for the same reasons as those for Boston Brook (reach 34). In reach 35, the 1-day high flow increased about 19 percent, from $14.4 \mathrm{ft}^{3} / \mathrm{s}$ in 1991 to $17.2 \mathrm{ft}^{3} / \mathrm{s}$ at buildout, and low flows decreased about 3 percent (table 15).

In reach 28 , about 36 percent ( 382 acres) of the 1,052-acre subbasin area was developable, of which 71 acres (about 19 percent of the developable area) were apportioned to IMPLNDs, reflecting a greater amount of land zoned for commercial and high-density residential use. The EIA in the subbasin increased from 3.8 percent in 1991 to 10.5 percent at buildout. Despite a larger percentage increase in EIA in reach 28 than in reaches 34 and 35, buildout still had a modest effect on streamflow in this reach (fig. 56C). In reach 28 , the 1-day high flow increased from $14.7 \mathrm{ft}^{3} / \mathrm{s}$ for 1991 land use to $16.5 \mathrm{ft}^{3} / \mathrm{s}$ at buildout (about 12 percent), and low flows were slightly lower (about 4 percent) at buildout (table 15). A prevalence of sand and gravel in this subbasin may account for the lack of response to increased EIA compared to reaches 34 and 35 .

In reach 27 , about 40 percent (169 acres) of the 421-acre subbasin was developable, of which 85 acres (about 50 percent of the developable area) was apportioned to IMPLNDs. This increased the EIA in the subbasin from 8.6 percent in 1991 to 28.9 percent at buildout. The large percentage increase in EIA relative to the other reaches discussed in this section indicates that most of the developable land in this subbasin was zoned for one or more commercial and industrial uses (table 10). A change in EIA of this magnitude and large percentage increases in the amount of pervious commercial area resulted in more pronounced effects on both high and low flows (fig. 56D). The median 1-day and 7-day high flows increased by 67 percent and 33 percent, respectively, whereas the median 1-day and 7-day low flows at buildout decreased by 28 percent and 26 percent, respectively (table 15 ). Simulation results for this subbasin indicate that a relatively large increase in EIA (percent increase of over 200 percent) is needed to substantially alter simulated flows; alterations in flow ranged from near zero percent to 20 percent in other areas of the Ipswich River Basin. Notably, changes of this magnitude occurred in a small subbasin, in which land-use change affected a relatively large percentage of the drainage area.

In reaches 19 and 56, which show land-use-change effects over large drainage areas (44.4 and $125 \mathrm{mi}^{2}$, respectively), differences in streamflow for 1991 land use and land use at buildout generally were small (figs. 56E, F); percent changes ranged from zero to 10 percent (table 15). This result is consistent with the relatively small percentage increases in EIA in these large drainage areas. For example, the EIA in the reach 19 drainage area increased 0.9 percent, from 6.8 percent in 1991 to 7.7 percent at buildout. Similarly, the EIA in the reach 56 drainage area increased 1.2 percent, from 4.7 percent in 1991 to 5.9 percent at buildout.

These examples demonstrate that land-use change associated with buildout generally had modest (percent change in the range of 0 to 20 percent) effects on simulated streamflow because most of the developable land in the basin in 1991 was forested or open and zoned for low-density residential development (table 11). Because there was a relatively 

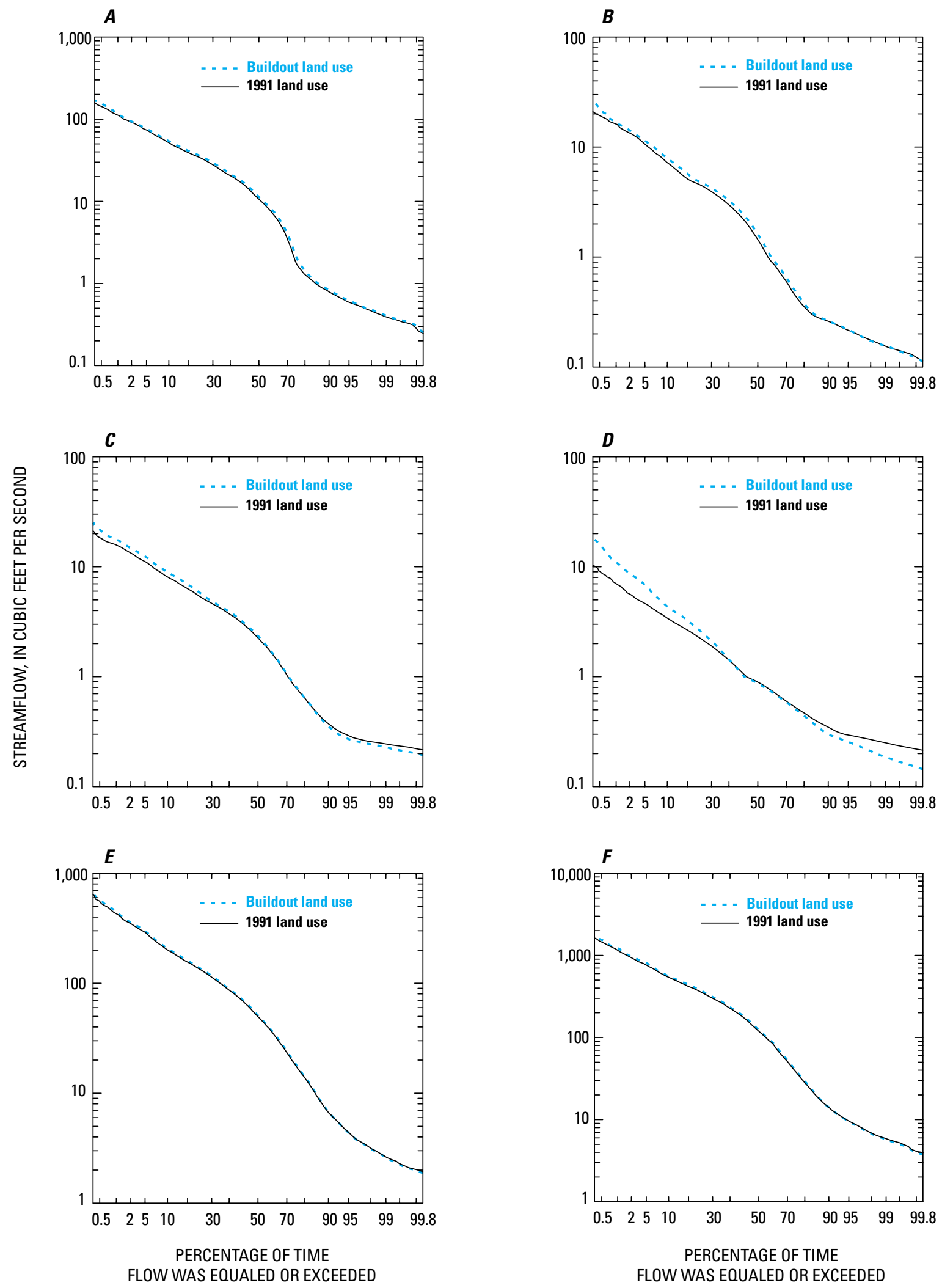

Figure 56. Flow-duration curves of daily mean streamflow at $(A)$ reach 34, Boston Brook above mouth, Middleton, $(B)$ reach 35, Ipswich River above Nichols Brook, Middleton, $(C)$ reach 28, Ipswich River at Maple Street, Middleton, $(D)$ reach 27, Middleton Pond Brook, Middleton, $(E)$ reach 19, Ipswich River at South Middleton streamgage, and $(F)$ reach 56, Ipswich River at Ipswich streamgage in the Ipswich River Basin developed from long-term (1961-1995) simulations with 1991 land use and potential land use at buildout. Simulations incorporate updated baseline withdrawals. Reach locations are shown in fig. 49. 


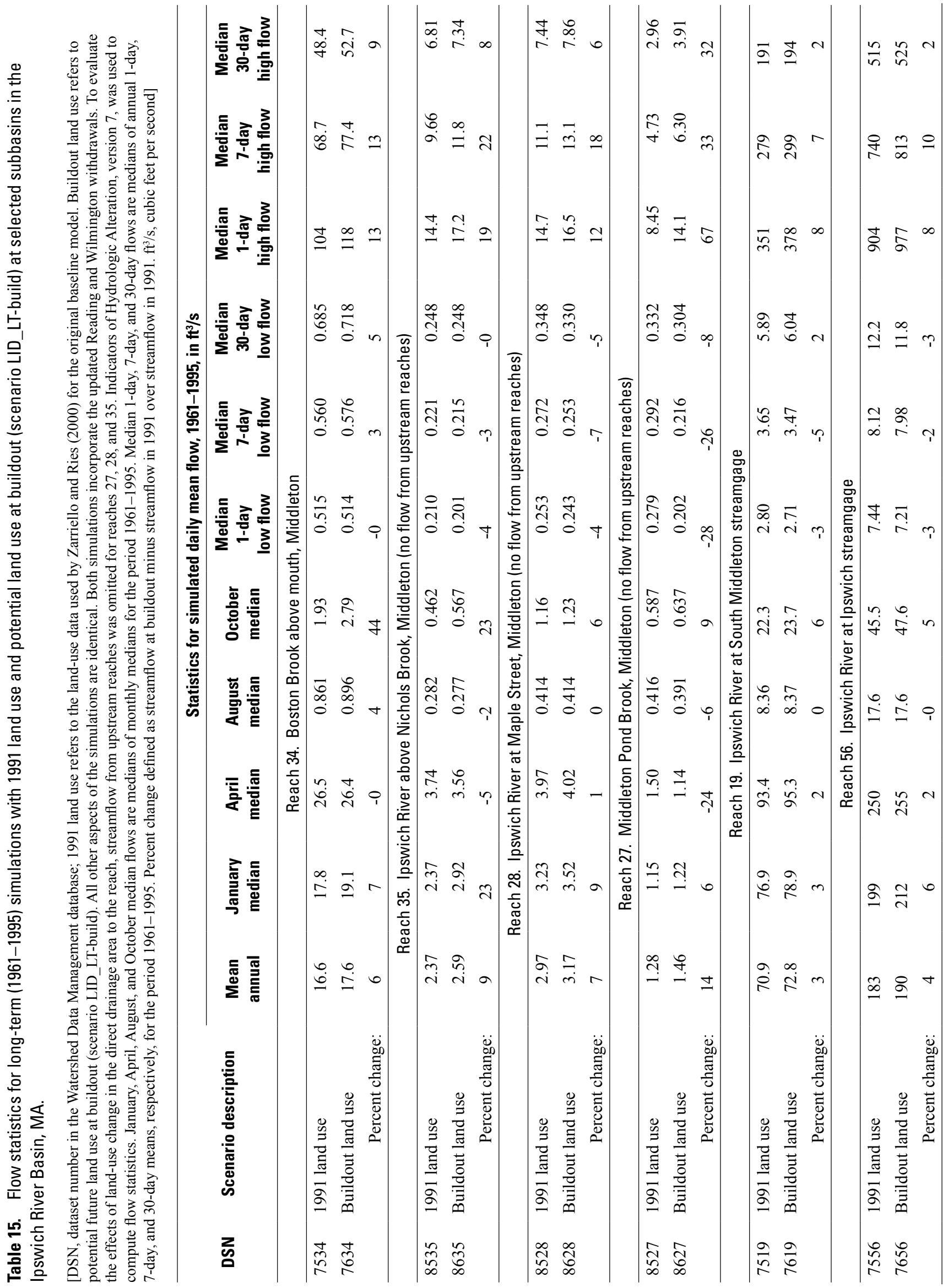


small amount of EIA associated with low-density residential development (2.5 percent in the calibrated Ipswich River Basin HSPF model), increases in this type of land use could not result in large changes in the amount of EIA in the basin. In addition, for a given type of underlying surficial geology, the runoff characteristics for forest and pervious low-density residential land use were similar.

The most significant difference between forest and lowdensity residential development was the amount of water lost to evapotranspiration and consequent reductions in runoff. Previous studies have shown that deforestation increases both peak flows and base-flow runoff (Bent, 2001; Hornbeck and others, 1993; Bosch and Hewlett, 1982). In humid climates, low water yields in forested watersheds have been attributed to increased canopy-intercepted evaporation and more intensive root-zone transpiration during the growing season (Bent, 2001; Calder, 1993; Robinson and others, 1991). These processes reduce soil moisture, reduce recharge, and lower water tables, and, thus, reduce the base-flow contribution to streamflow. Consequently, although low-density residential areas received slightly less infiltration per unit area because of EIA, the comparatively large evapotranspiration losses from forested areas resulted in slight increases in summer low flows in low-density residential areas. In the Ipswich River Basin HSPF model, forest and low-density residential HRUs were assigned parameter values that reflect these differences in the magnitude of evapotranspiration losses (Zarriello and Ries, 2000). Other aspects of the effects of buildout on streamflow were not evaluated in this study. For example, although forests may produce lower water yields relative to residential areas with less deep-rooted vegetation, land-use studies have indicated that the quality of groundwater underlying forested areas typically was less affected by human activities than other land uses, and was considered to represent background conditions (Grady, 1994). Coles and others (2004) found that changes in water chemistry in coastal New England streams were strongly associated with the intensity of urban development.

Conversion of forest to low-density residential land use had only a modest effect on simulated streamflow; by comparison, conversion of forest to commercial land use had a much more pronounced effect on simulated streamflow because of the relatively large increases in EIA which resulted in increased surface runoff. Although the effect of urbanization on flood peaks was relatively clear, the effect of increasing urbanization on low flows showed conflicting results (Brandes and others, 2005; Rose and Peters, 2001), probably because low flows are determined by the net response to complex interactions among climate, land use, water use, and water infrastructure (Claessens and others, 2006; Lerner, 2002; Dow and DeWalle, 2000). Because of the uncertainty associated with assigning parameter values to individual HRUs (see the "Model Limitations" section of the report) and the lack of representation of specific basin features, such as urban water infrastructure, these simulation results were more representative of relative rather than absolute change in streamflow in response to land-use change. In addition, the effects of increased water withdrawals and wastewater return flows needed to serve a larger population at buildout (for example, Barbaro, 2007) were not evaluated in this study.

\section{Simulation of Low-Impact-Development Retrofits Upstream from the South Middleton Streamgage}

A 50-percent reduction of EIA upstream from the South Middleton streamgage (reach 19) generally had modest effects on streamflow at the subbasin scale (fig. 57; table 16). In reach 5 (Lubbers Brook above Route 38, Wilmington), EIA decreased from 5.2 percent (updated baseline simulation with 1991 land use) to 2.6 percent after the EIA was reduced to simulate LID retrofits. The EIA for this reach is similar to the median value of 5.9 percent for the 19 subbasins upstream from the streamgage at South Middleton, and thus, the response of streamflow to reduced EIA is representative of a typical subbasin upstream from reach 19. The flow-duration curve (fig. 57A) and the flow statistics (table 16) indicate that reducing EIA by 50 percent had a small effect on high and low flows compared to the baseline simulation; for example, the median 1-day high flow decreased about 4 percent, from 21.7 to $20.8 \mathrm{ft}^{3} / \mathrm{s}$. The decrease was small because only a small percentage of the subbasin area ( 47 of 1,811 acres) was subtracted from IMPLNDs and added to the various urban PERLNDs.

The direct reach 2 drainage area (Maple Meadow Brook above mouth, Wilmington) had the highest EIA of all the subbasins above the Middleton streamgage. The EIA was 10.6 percent of the entire drainage area and 21.9 percent of the direct drainage area to the reach. Although in 1991 the entire drainage area to reach 2 had nearly double the EIA of reach 5 , the flow-duration curve and flow statistics indicate that the decrease from 10.6 to 5.3 percent EIA still had a modest effect on simulated low and high flows (fig. 57B; table 16). For example, the median 1-day high flow at this location decreased 6 percent, from 49.7 to $46.8 \mathrm{ft}^{3} / \mathrm{s}$ ), whereas the median 1-day low flow increased 7 percent, from 0.590 to $0.634 \mathrm{ft}^{3} / \mathrm{s}$. In the highly urban direct drainage area of reach 2 , a 50-percent reduction in EIA corresponded to a reduction in EIA of 46 acres in a drainage area of 422 acres. Consequently, decreases in high flows were pronounced (the median 1-day high flow decreased about 20 percent), but low flows were largely unaffected (fig. 57C), presumably because increased evapotranspiration from the expanded PERLND area reduced base flow. Simulation results for reach 19, which reflect the integrated effects of LID retrofits for the entire drainage area, were similar to results for reach 5 (fig. 57D).

Overall, simulation of widespread reduction of EIA to 50 percent of values in the updated baseline model (1991 land use) resulted in modest effects (percent differences of less than 20 percent) on simulated streamflow upstream from the South Middleton streamgage. Even in this relatively urban part of the Ipswich River Basin, the heterogeneous mix of land uses resulted in total EIAs that were small percentages of subbasin areas. Consequently, reducing these areas by 50 percent did not have a pronounced effect on simulated streamflow at the 

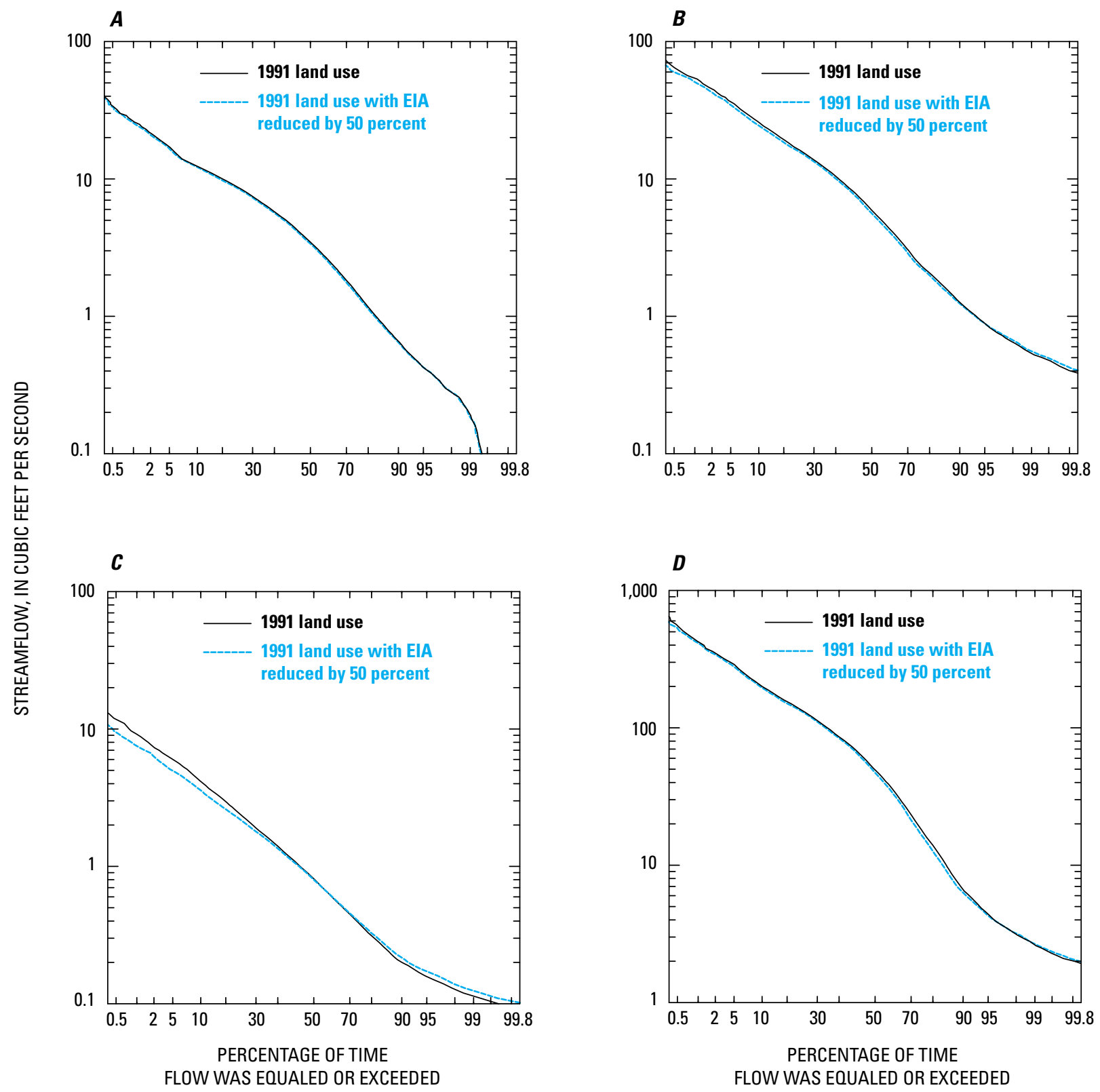

Figure 57. Flow-duration curves of daily mean streamflow at $(A)$ reach 5, Lubbers Brook above Route 38, Wilmington, $(B)$ reach 2, Maple Meadow Brook above mouth, Wilmington, $(C)$ reach 2, Mapple Meadow Brook above mouth (no flow from upstream reach), and $(D)$ reach 19, Ipswich River at South Middleton streamgage in the Ipswich River Basin developed from long-term (1961-1995) simulations with 1991 land use and 1991 land use with effective impervious area for each urban land-use category reduced by 50 percent to simulate low-impact-development retrofits. Reach locations are shown in fig. 49. ElA, effective imperious area. 


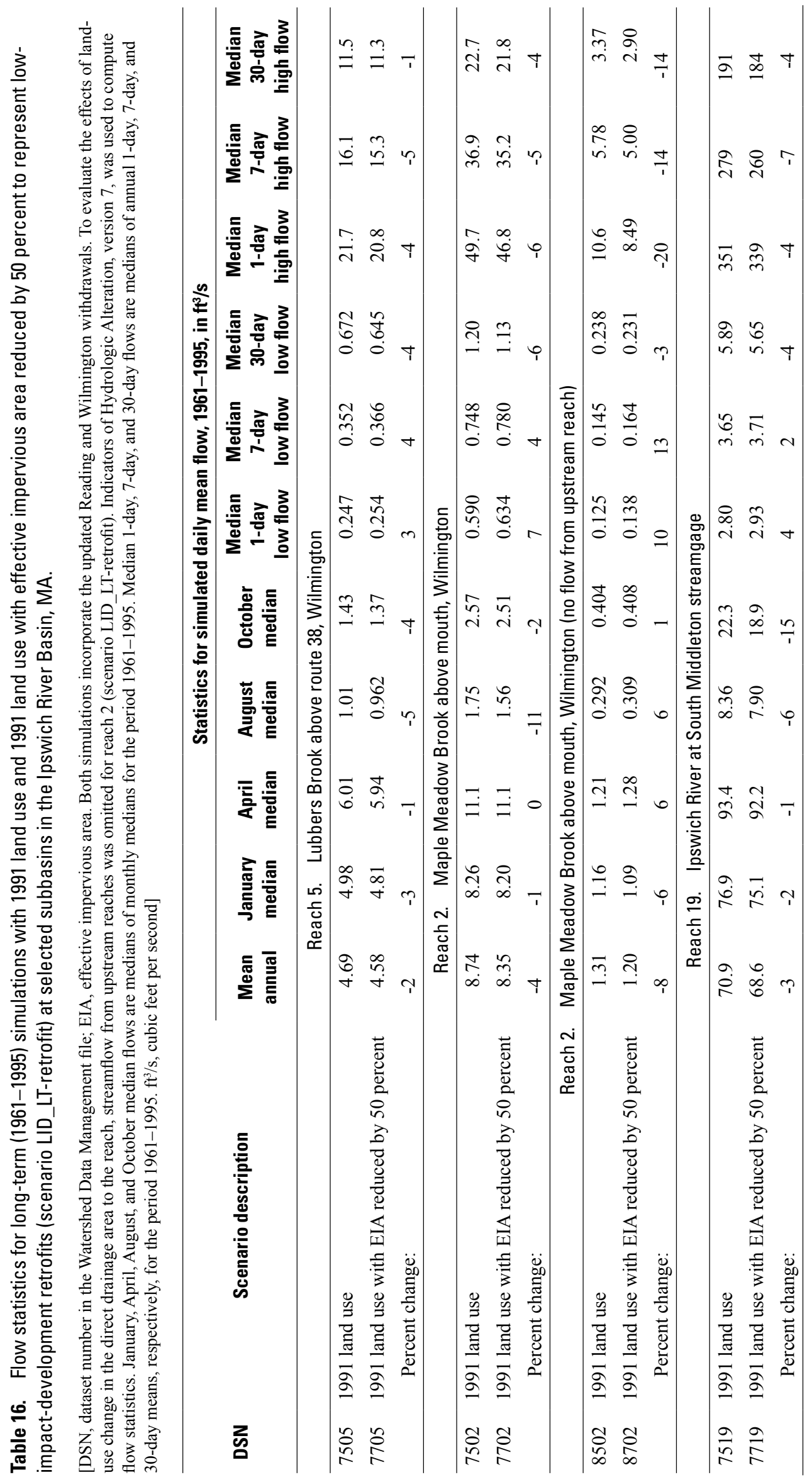


subbasin scale. These results may have general significance for other drainage basins. If, because of heterogeneous land use, low total EIA is a general characteristic of large drainage areas, then widespread LID practices that reduce EIA may not substantially affect flows in large rivers and tributary streams. On the other hand, LID practices that reduce EIA on a local scale may have substantial effects on flows in small streams because (1) EIA as a percentage of the drainage area may be large and (2) a large percentage decrease in EIA may be attainable. The effect of scale and sensitivity to variable amounts of EIA are discussed in greater detail in the "Local-Scale Simulation" section of the report.

\section{Water Conservation Simulation}

Reductions in water use were expected to have their greatest effects on low flows in subbasins in which the streamflow-depletion rate was high relative to the rate of streamflow in the absence of withdrawals (Barbaro, 2007). Small tributaries affected by municipal withdrawals (Wills Brook (reach 17), Idlewild Brook (reach 49), and Howlett Brook (reach 53)) were chosen to illustrate the effects of hypothetical water-use reductions from widespread application of results from the water-conservation pilot programs (appendixes A1, A2) in the Ipswich River Basin (fig. 49). Streamflow depletion from time-varying groundwater withdrawals and direct surface-water withdrawals are collectively referred to as "withdrawals" in this section.

Reach 17 (Wills Brook, North Reading) is a 1,126 acre headwaters subbasin containing five municipal withdrawals for the town of Lynnfield and additional withdrawals for the Sagamore Springs Golf Club; the withdrawals for the golf club were not altered for this analysis. The average 1989-1993 withdrawals for the town were $0.47 \mathrm{ft}^{3} / \mathrm{s}(0.30 \mathrm{Mgal} / \mathrm{d})$. The town-wide application of hypothetical water-use reductions from the water-conservation pilot programs reduced withdrawals by $0.015 \mathrm{ft}^{3} / \mathrm{s}$, or 3.1 percent (table 12). The total withdrawals from the reach decreased from 0.56 to $0.55 \mathrm{ft}^{3} / \mathrm{s}$. Reach 49 (Idlewild Brook, Hamilton) is a 1,664-acre headwater subbasin dominated by Wenham swamp (43 percent of subbasin area). The subbasin contains three municipal withdrawals for the town of Hamilton and two municipal withdrawals for the town of Wenham. The average 1989-1993 withdrawal from reach 49 was $1.36 \mathrm{ft}^{3} / \mathrm{s}(0.88 \mathrm{Mgal} / \mathrm{d})$. The average reduced rate applied to the individual wells in the subbasin, accounting for the hypothetical water-use reductions for the towns of Hamilton and Wenham, was $1.27 \mathrm{ft}^{3} / \mathrm{s}(0.82 \mathrm{Mgal} / \mathrm{d})$, a reduction of 6.6 percent. Reach 53 (Howlett Brook, Topsfield) is a 6,976-acre subbasin containing one municipal withdrawal for the town of Topsfield. The average 1989-1993 withdrawal rate from the subbasin was $0.61 \mathrm{ft}^{3} / \mathrm{s}(0.39 \mathrm{Mgal} / \mathrm{d})$. The average reduced withdrawal rate was $0.58 \mathrm{ft}^{3} / \mathrm{s}(0.37 \mathrm{Mgal} / \mathrm{d})$, a reduction of 5.0 percent.

Flow-duration curves indicate that withdrawal reductions on the order of 5 percent had a small effect on simulated low flows in these reaches (figs. 58A, B, C). Hypothetical 20-percent reductions in withdrawal rates resulted in slightly higher simulated low flows, but flows for all withdrawal scenarios were more similar to each other than to flows for the no-withdrawal scenario. Flow-duration curves for reach 19 (Ipswich River at South Middleton streamgage) indicate that the hypothetical water-use reductions from the waterconservation pilot programs had negligible effects on simulated low flows in the Ipswich River at this location (fig. 58D). This result is consistent with previous reduced-withdrawal simulations for this reach conducted with the original baseline withdrawals (Zarriello, 2002a). Local effects of withdrawal reductions on small streams in the immediate vicinity of withdrawal wells would likely be more pronounced, but they could not be evaluated with the HSPF model in its current form. ${ }^{3}$

\section{Local-Scale Simulations}

Simulated streamflow arising from combinations of land use, underlying surficial geology, percentage of EIA, and development patterns (conventional versus cluster) were compared to each other at a local (100-acre) scale (table 13).

\section{Conventional Development}

To evaluate the effects of uniform land-use change on streamflow, long-term (1961-1995) simulations were conducted for 100-acre parcels represented as undeveloped (forest) or as developed (low-density residential, high-density residential, or commercial) land uses (fig. 59). To facilitate comparison with the basin-scale results described above, the local-scale simulations of uniform land uses were conducted with model-calibrated EIA values. Converting 100 acres of forest overlying till to commercial development (63 acres EIA; 37 acres pervious commercial area) increased the simulated median 1-day high flow about 307 percent, from 1.62 to $6.60 \mathrm{ft}^{3} / \mathrm{s}$, and decreased the median 1-day low flow about 33 percent, from 0.024 to $0.016 \mathrm{ft}^{3} / \mathrm{s}$ (fig. 59A; table 17). Conversion of 100 acres of forest overlying till to high-density residential development overlying till (14 acres EIA; 86 acres pervious high-density residential area) had less of an effect on high flows; the median 1-day high flow increased about 120 percent, from 1.62 to $3.58 \mathrm{ft}^{3} / \mathrm{s}$. For HRUs overlying sand and gravel (fig. 59B), the relative differences among land-use types were the same as for HRUs overlying till; however, the absolute differences among land-use types were more pronounced. For example, conversion of 100 acres of forest

\footnotetext{
${ }^{3}$ Subsequent to this analysis, DCR provided an updated average per-acre savings for the weather-based irrigation systems on athletic fields. The peracre savings increased from 16,241 to 21,128 gallons per acre per month (appendix A2). Simulations were not updated because the water-conservation savings as a percentage of average town pumping rate for the calibration period increased only by 0.3 percent on average for the 11 towns and water suppliers considered in the study (table 12). The average percentage for the 11 towns increased from 3.8 to 4.1 percent, with the maximum percentage increase ( 0.6 percent) for Wilmington and Topsfield and the minimum percentage increase ( 0.1 percent) for Danvers Water Supply, Salem-Beverly water supply, Lynnfield, and Lynn.
} 
$\boldsymbol{A}$

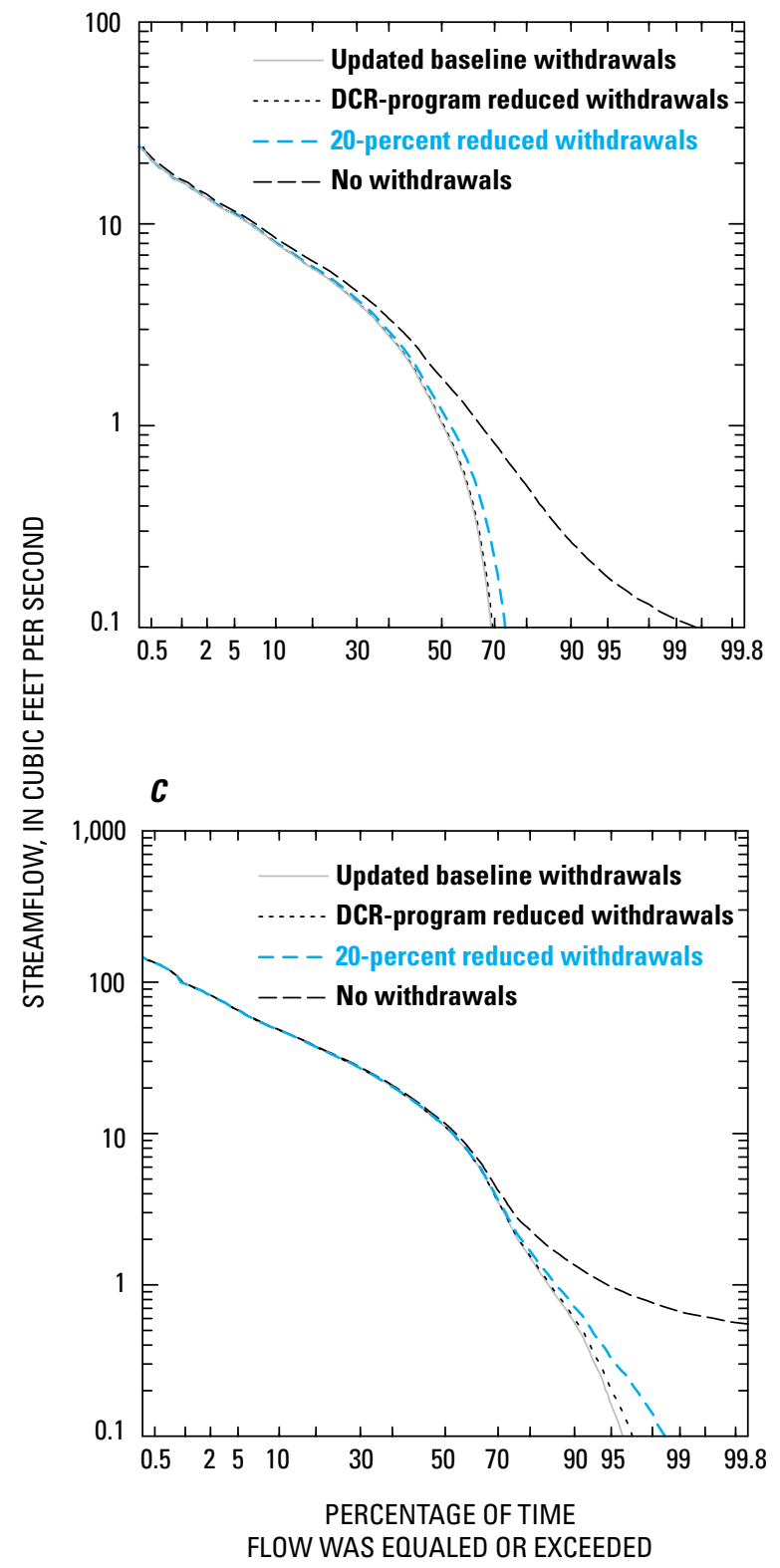

B
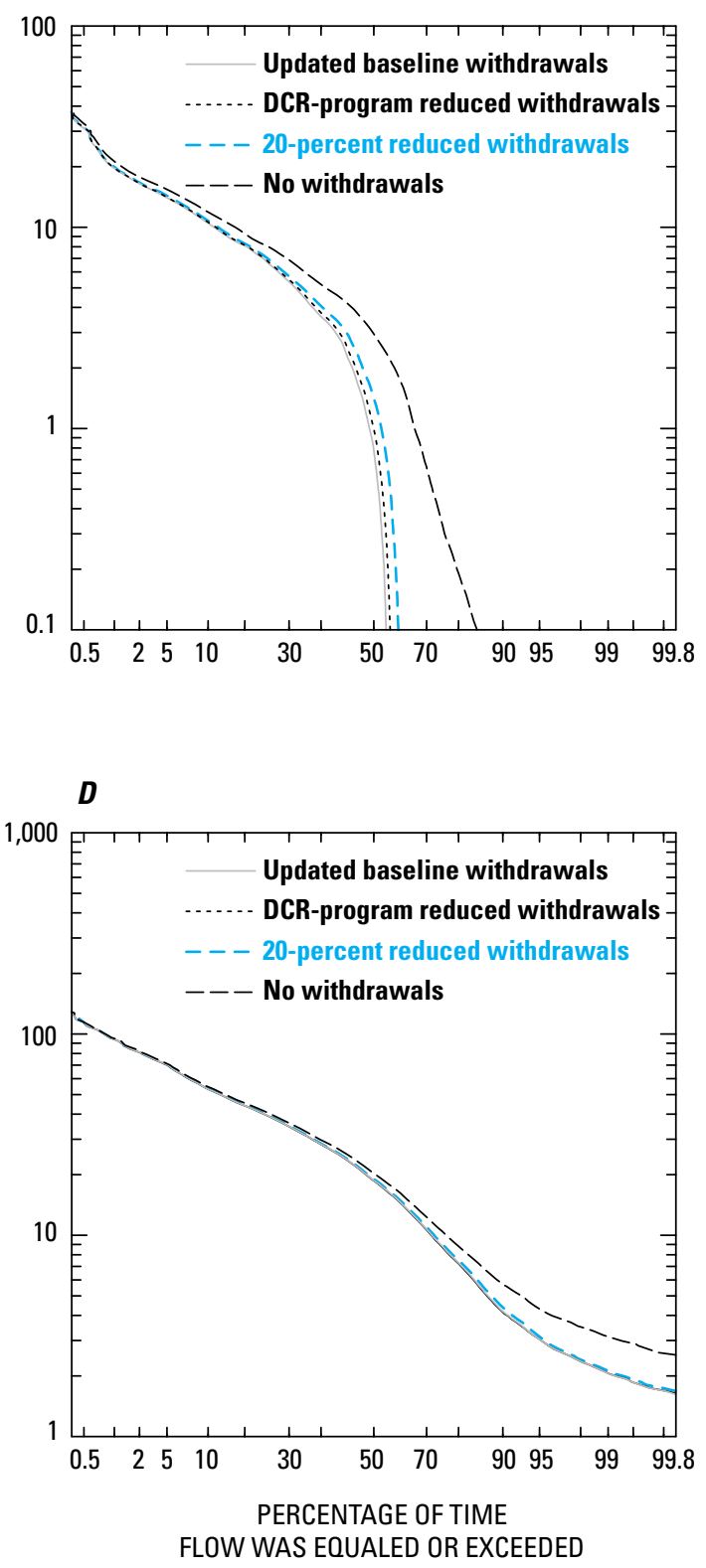

Figure 58. Flow-duration curves of daily mean streamflow at $(A)$ reach 17, Wills Brook, North Reading, $(B)$ reach 49, Idlewild Brook, Hamilton, $(C)$ reach 53, Howlett Brook, Topsfield, and $(D)$ reach 19, Ipswich River at South Middleton streamgage in the Ipswich River Basin developed from long-term (1961-1995) simulations with updated baseline withdrawals, withdrawals reduced by scaled-up data from Massachusetts Department of Conservation and Recreation water-conservation pilot programs, withdrawals reduced by 20 percent, and no withdrawals. Reach locations are shown in fig. 49. DCR, Department of Conservation and Recreation. 
$\boldsymbol{A}$ Uniform undeveloped and developed land uses overlying till
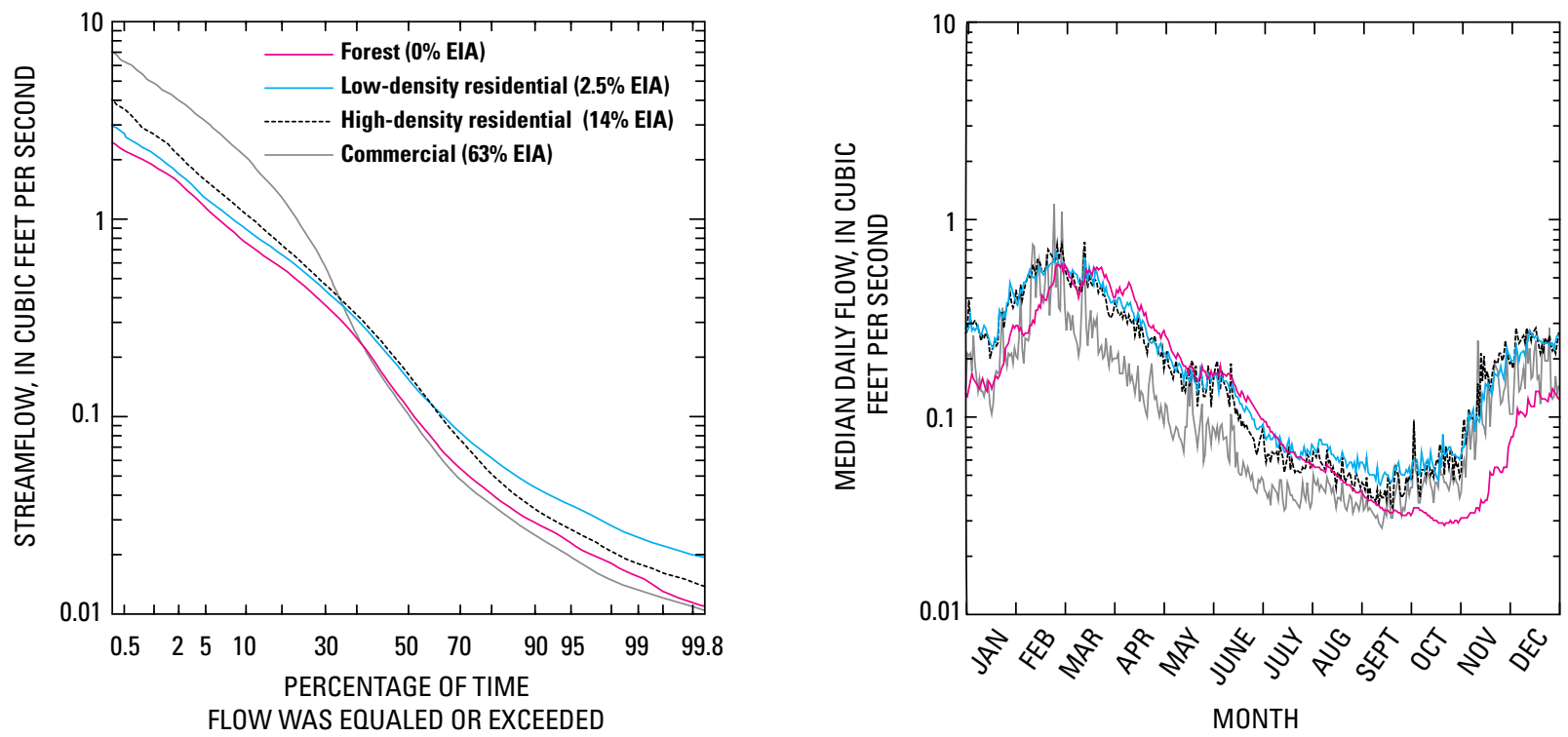

B Uniform undeveloped and developed land uses overyling sand and gravel
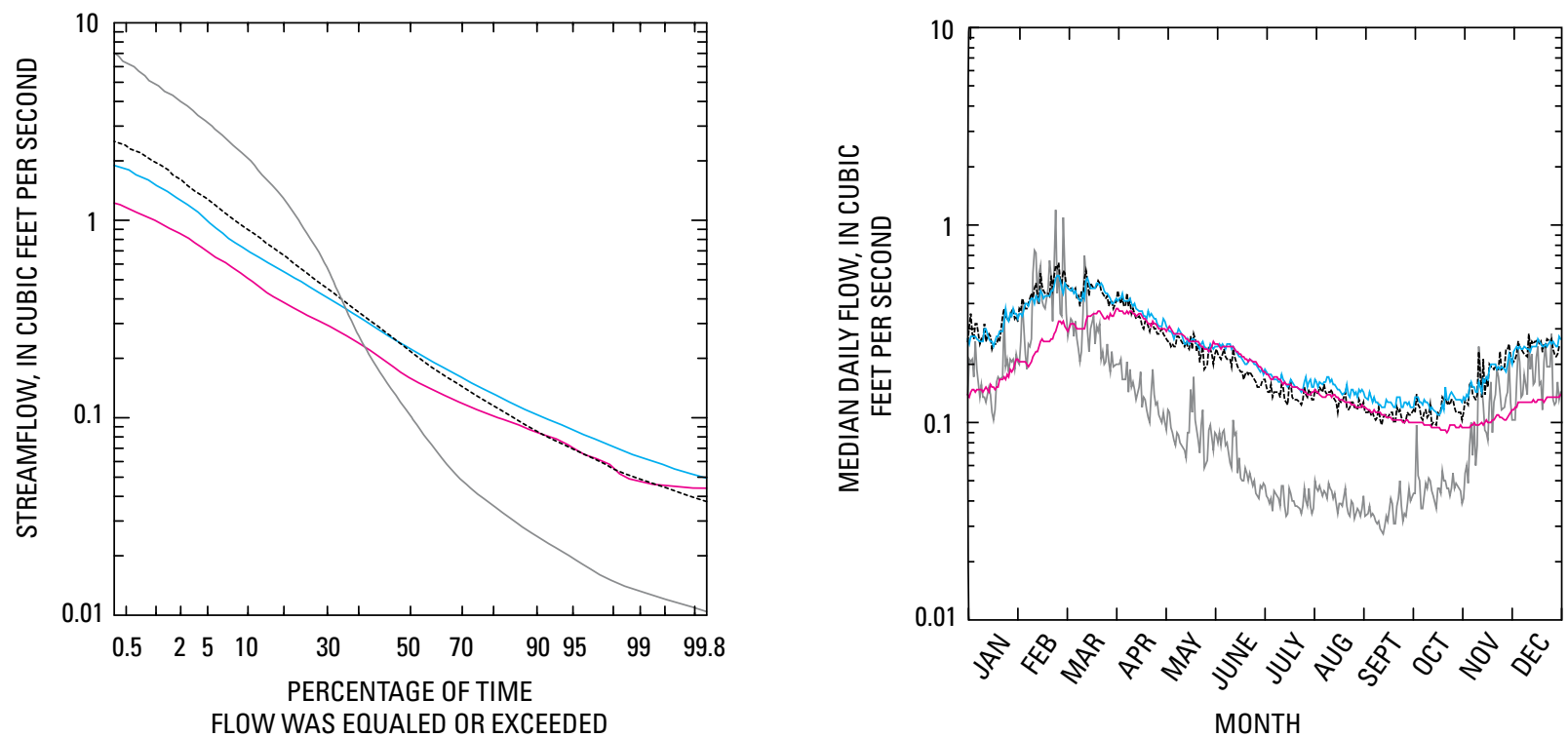

Figure 59. Flow-duration curves of daily mean streamflow and mean daily-flow hydrographs from long-term (1961-1995) local-scale simulations of runoff from 100-acre parcels of undeveloped (forest) land and conventionally laid-out developed (low-density residential, high-density residential, and commercial) land $(A)$ overlying till and $(B)$ overlying sand and gravel with model-calibrated effective impervious area in the Ipswich River Basin, MA. \%, percent; EIA, effective impervious area. 


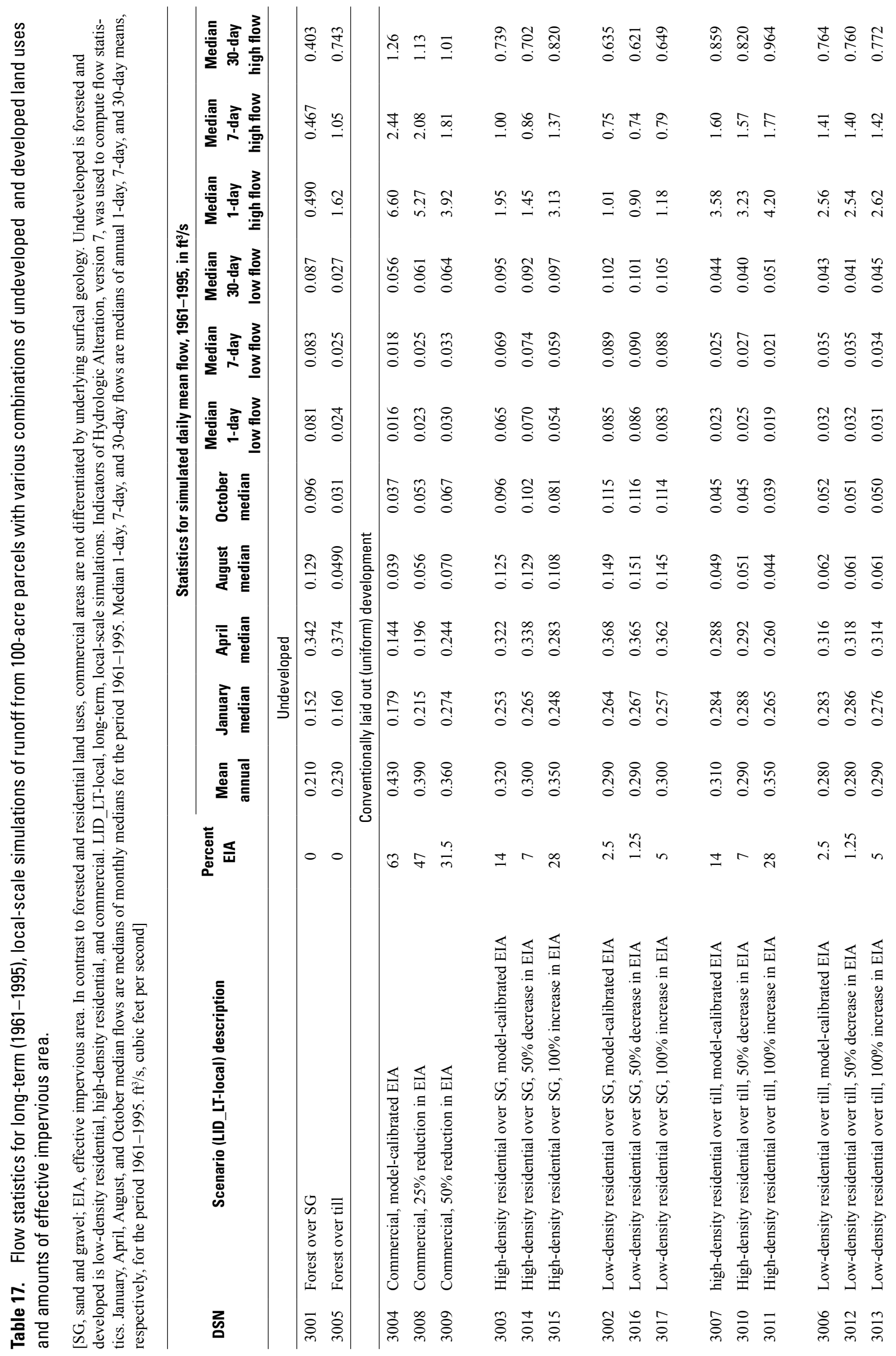




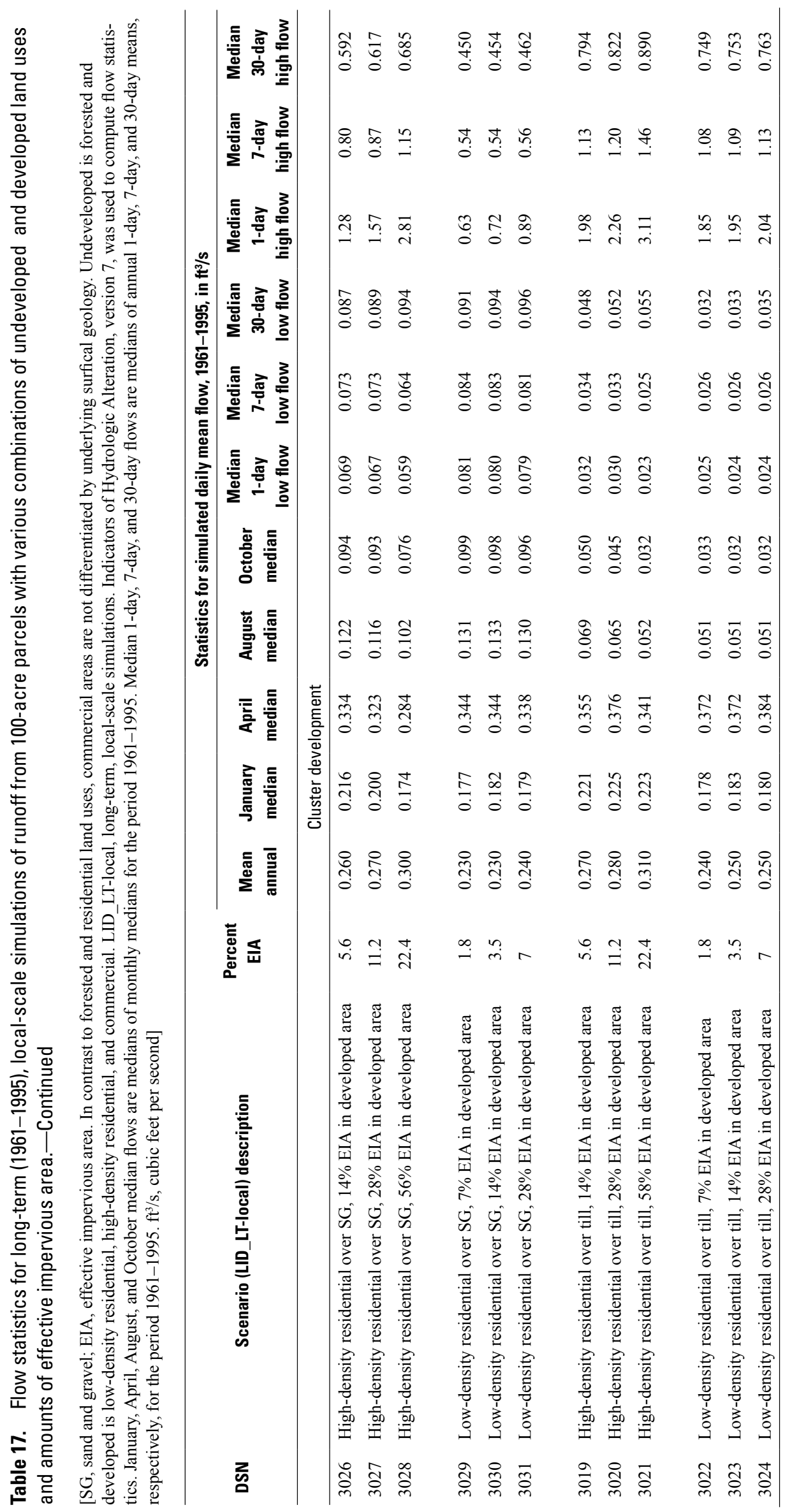


overlying sand and gravel to commercial land use increased the simulated median 1-day high flow about 1,250 percent, from 0.49 to $6.60 \mathrm{ft}^{3} / \mathrm{s}$. This difference occurred because the pervious HRUs overlying sand and gravel allowed for more infiltration and produced lower peak flows compared to the pervious HRUs overlying till. The pervious commercial HRU was not differentiated by underlying geology.

Converting forest to low-density or high-density residential land use increased simulated high flows but notably also increased most of the simulated medium and low flows for HRUs overlying both till and sand and gravel (figs. 59A, B). As discussed previously, both residential HRUs had less simulated evapotranspiration losses than forested HRUs, producing more discharge to streams as interflow or base flow. Relative differences in runoff and evapotranspiration for the developed and undeveloped HRUs involved in the local-scale simulations are shown by the mean annual water budgets (fig. 60). Because of the uncertainty associated with model parameter values for the individual HRUs, the water-budget results were more representative of relative rather than absolute differences in the amount of runoff and evapotranspiration among HRUs.

The hydrographs of median daily streamflow show that flows for commercial land use are relatively flashy and vary more on a seasonal basis than flows for other land-use types (figs. 59A, B). This occurs mainly because of the large percentage of EIA (63 percent) associated with commercial development. Hydrographs for the forest, low-density residential, and high-density residential land uses overlying till generally follow the hydrograph for commercial land use, whereas hydrographs for the same land uses overlying sand and gravel generally vary less than those for commercial land use throughout the year, and flows are higher in the summer as a result of higher base flows.

Simulations conducted to evaluate the sensitivity of streamflow to the amount of EIA for conventional (that is, spatially uniform) development indicated that streamflow changed in proportion to changes in EIA (fig. 61). Reducing EIA associated with commercial land use to 50 percent of model-calibrated values had the largest effects on simulated flows because a percentage reduction of this magnitude corresponded to converting 31.5 percent of the drainage area from effective impervious to pervious surface (fig. 61A). For example, a 50-percent reduction in EIA decreased the median 1-day high flow by about 41 percent, from 6.60 to $3.92 \mathrm{ft}^{3} / \mathrm{s}$ (table 17), whereas the median 1-day low flow increased by about 88 percent, from 0.016 to $0.030 \mathrm{ft}^{3} / \mathrm{s}$. In contrast, the effects of reducing EIA by 50 percent for high-density and low-density residential land uses were less pronounced than for commercial land use because less of the drainage area was converted from effective impervious to pervious surface; the effect of reduced EIA on flows was larger for high-density residential land use than for low-density residential land use because more EIA was available for reduction (figs. 61B-E). Overall, these simulation results indicate that the largest reduction in streamflow alteration could potentially be achieved by implementing LID in areas with commercial land use followed by high-density residential land use. Only modest changes in simulated streamflow were observed for low-density residential land use.

For a given change in the percentage of EIA in a 100-acre parcel, the effect on simulated high flows was similar for all of the developed HRUs (fig. 62A). Differences in streamflow become less pronounced as the percentage of EIA increases. Flows were most similar for high EIA values because impervious surface constituted a larger proportion of the drainage area than pervious surface, and differences in the infiltration characteristics among the pervious HRUs decreased in influence. When the percentage of EIA was relatively low, surficial geology differences had a greater effect on simulated high flows (fig. 62A). For example, for EIA values less than about 10 percent, median 1-day high flows for HRUs overlying till were about double those for HRUs overlying sand and gravel. Overall, median 1-day high flows were more sensitive than median 7-day high flows to changes in EIA. Over the range of EIA values simulated (zero to 100 percent EIA), median 1-day high flows increased by a factor of about 5 , whereas median 7-day high flows increased by a factor of about 2 .

In contrast to the high flows, simulated low flows were affected to a much greater degree by the infiltration characteristics of the pervious, developed HRUs, and the effect of a given change in the amount of EIA was more dependent on the type of HRU (that is, there were larger differences in slope), although for a given HRU median 1-day and 7-day low flows were similar (figs. 62B, C). For relatively low EIA, subsurface geology and evapotranspiration losses greatly affected the amount of base flow to streams. Consequently, differences in the HRU characteristics that controlled these factors resulted in simulated streamflows varying by a factor of about five for low EIA values. The maximum median 1-day low flow occurred for the low-density residential overlying sand and gravel HRU $\left(0.00087 \mathrm{ft}^{3} / \mathrm{s} /\right.$ acre $)$ simulation, and the minimum median 1-day low flow was from the high-density residential HRU overlying till $\left(0.00027 \mathrm{ft}^{3} / \mathrm{s} /\right.$ acre $)$ simulation. As EIA increased, median 1-day and 7-day low flows approached zero. Such high EIAs are likely uncommon, and the simulation results for individual HRUs are not representative of a basin that is becoming urbanized because the interactions among processes, such as reduced evaporation caused by land-use changes (Dow and Dewalle, 2000) and increased recharge caused by urban water infrastructure (Lerner, 2002), could cause low flows to increase at the watershed scale.

The vertical lines in figure 62 are the model-calibrated EIA values for low-density residential development (2.5 percent), high-density residential development (14 percent), and commercial development (63 percent). As indicated by the model-calibrated value, EIA for low-density developments typically would be low; thus, streamflow would be relatively insensitive to EIA reduction for this type of development, regardless of the physical properties of the underlying surficial geology and the magnitude of the flow. Similarly, for mixed urban development that has low total EIA as a percentage of the drainage area, reductions in EIA 


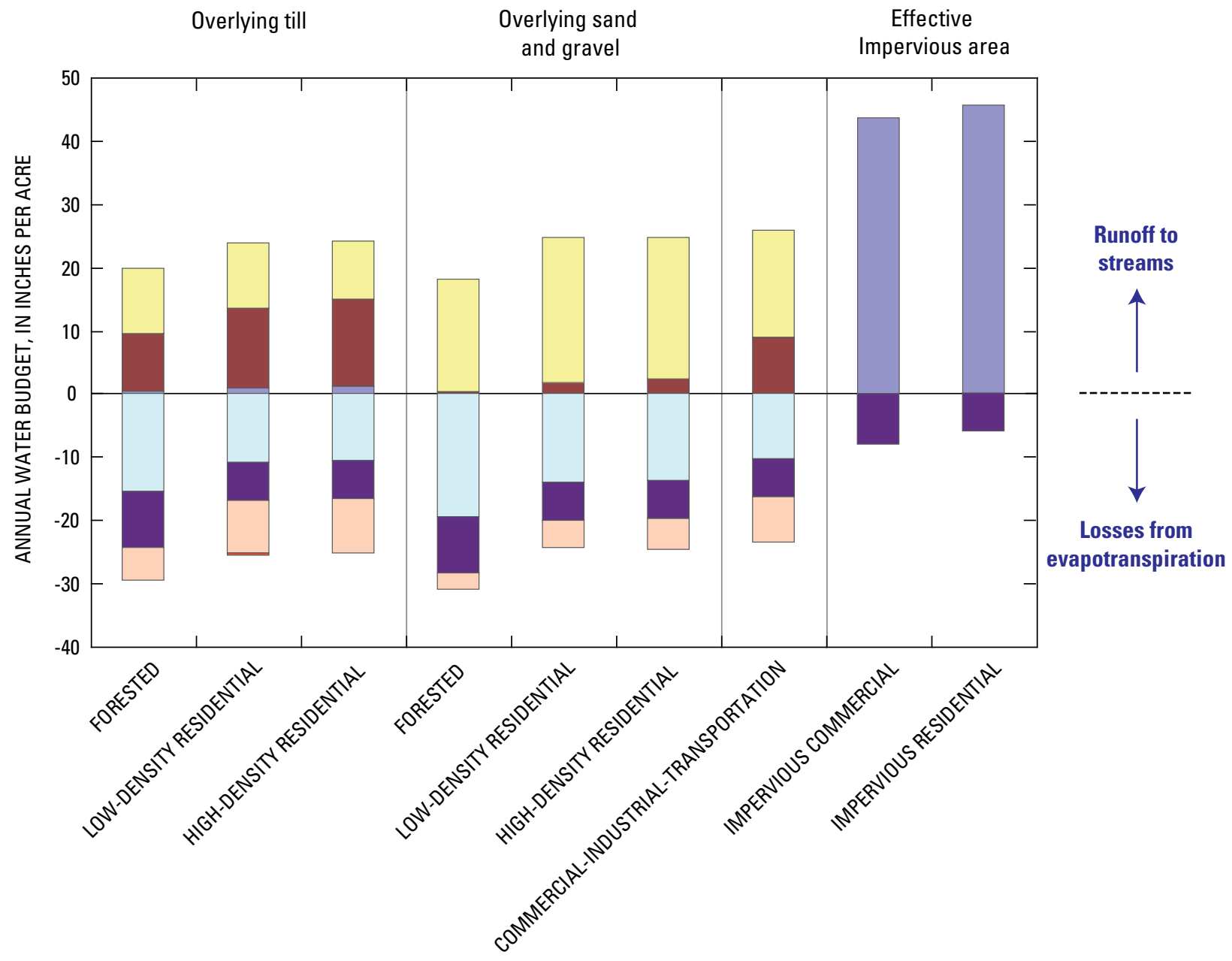

\section{EXPLANATION}

Runoff from

AGWO-Active groundwater

IFWO-Interflow

SURO-Surface
Evapotranspiration from

AGWET-Active groundwater

UZET-Upper soil zone

CEPE-Interception

LZET_Lower soil zone

Figure 60. Mean annual water budgets for forested and developed hydrologic response units simulated in the Ipswich River Basin, MA. 

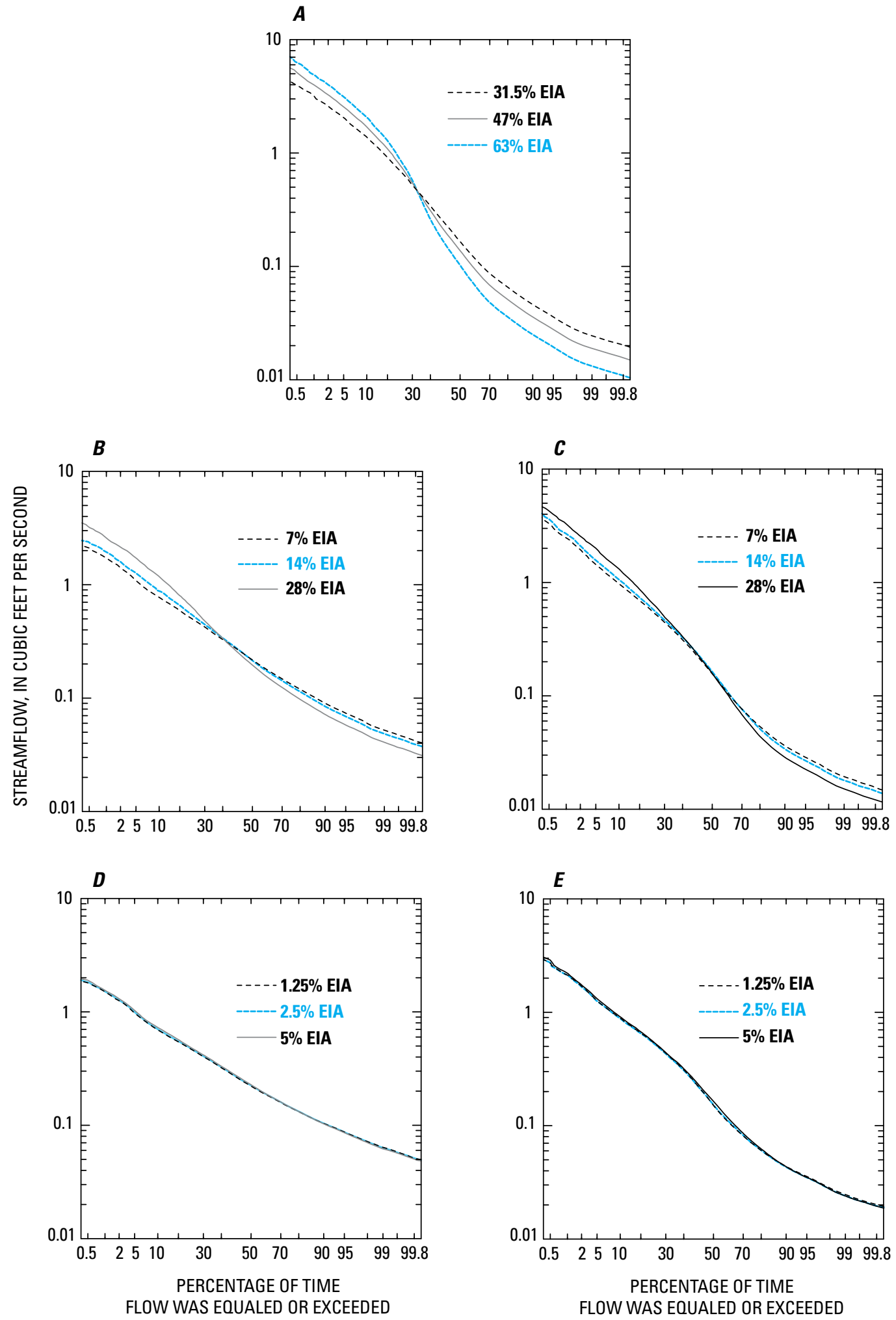

Figure 61. Flow-duration curves of daily mean streamflow from long-term (1961-1995) local-scale simulations of runoff from 100-acre parcels of conventionally laid-out (uniform) (A) commercial development, $(B)$ high-density development overlying sand and gravel, $(C)$ high-density residential development overlying till, $(D)$ low-density residential development overlying sand and gravel, and (E) low-density residential development overlying till with various amounts of effective impervious area (EIA) in the Ipswich River Basin, MA. Blue curves represent model-calibrated EIA values. 


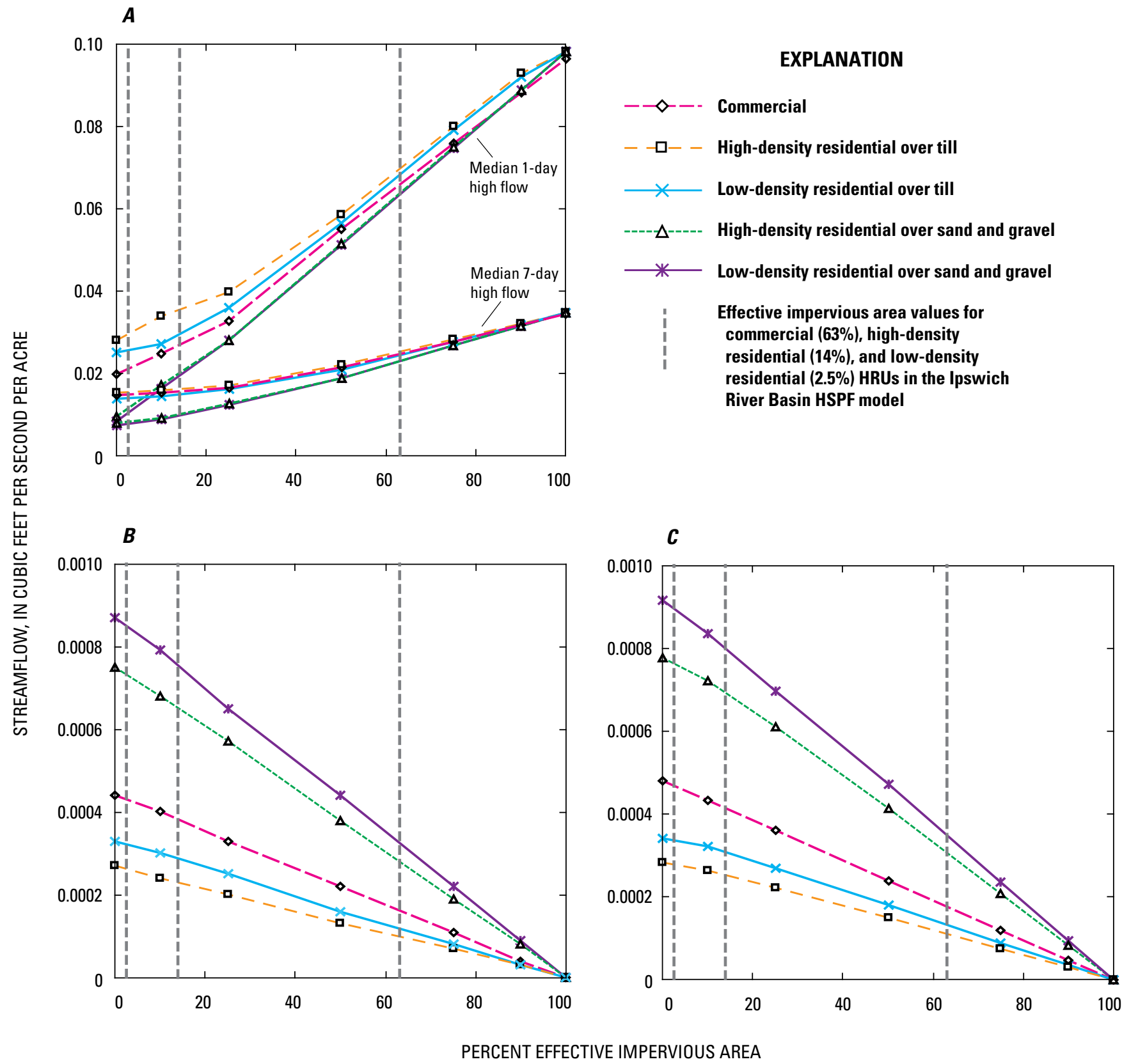

Figure 62. (A) Median 1-day and 7-day high flows, $(B)$ median 1-day low flows, and $(C)$ median 7-day low flows from long-term (19611995) simulations of runoff from 100-acre parcels of conventionally laid out (uniform) development with various amounts of effective impervious area in the Ipswich River Basin, MA. HRU, hydrologic response unit; HSPF, Hydrologic Simulation Program FORTRAN. 
likely would have modest effects on streamflow. This result is consistent with the results for the basin-scale simulations, particularly the LID retrofit and buildout simulations. Although the EIA values, parameter values for individual land-use types, and resulting simulated streamflows are specific to this study, there could be general significance to the conclusion that relatively modest changes in streamflow would be realized by reducing EIA for uniform or mixed land uses that have low initial EIA values. Small changes in EIA could have substantial effects on water quality and stream ecology (for example, fish assemblages in eastern Massachusetts streams (David Armstrong, U.S. Geological Survey, written commun., 2008)), but evaluating these effects was beyond the scope of this study.

\section{Flood-Peak Ratios}

To evaluate the magnitude of flood-peak differences produced by the long-term (1961-1995) local-scale simulations of runoff from 100-acre parcels with uniform land use, 1-day high flow (daily peak flow) frequency probabilities were computed by fitting annual series of daily high flows to the log-Pearson Type III distribution by use of SWSTAT, a program that computes surface-water statistics (Lumb and others, U.S. Geological Survey, written commun., 1994).

Previous studies have shown that urbanization affects the magnitude and frequency of flood flows (Beighley and Moglen, 2003; Booth and Jackson, 1997; Moscrip and Montgomery, 1997; Hollis, 1975; Leopold, 1968). For example, on the basis of a compilation of existing studies, Hollis (1975) showed that small floods (recurrence intervals of 1 year or less) can increase by a factor of 10 or more, depending on the degree of urbanization, and that the effects of urbanization decrease as flood recurrence intervals increase. A common explanation for the decreased effect of urbanization on larger floods is that undeveloped watersheds become so saturated during prolonged storms that the importance of infiltration is reduced and the channel network is extended in size, producing a hydrologic response like that of an impervious watershed (Hollis, 1975). Consequently, an undeveloped watershed could produce large floods similar in magnitude to a comparable developed watershed.

Ratios of the flood peaks after development (based on the commercial HRU) to those before development (based on the forest overlying till HRU or the forest overlying sand and gravel HRU) were plotted as a function of the recurrence interval of the flood, and the amount of EIA associated with commercial land use showed that simulated daily peak flows declined with increasing recurrence interval and with the amount of EIA associated with commercial development (fig. 63). For the contrast in infiltration characteristics between commercial development and forest overlying sand and gravel (fig. 63A), flood peaks after development were as much as 30 times higher than before development for small floods with a return period on the order of 1 year or less. For the contrast in infiltration characteristics between commercial development and forest overlying till (fig. 63B), flood peaks after development were as much as 10 times higher for small floods than before development. For large floods, ratios decreased but generally remained greater than one. For example, daily peak flows for 100-year floods were about 10 times higher after forest overlying sand and gravel was converted to commercial

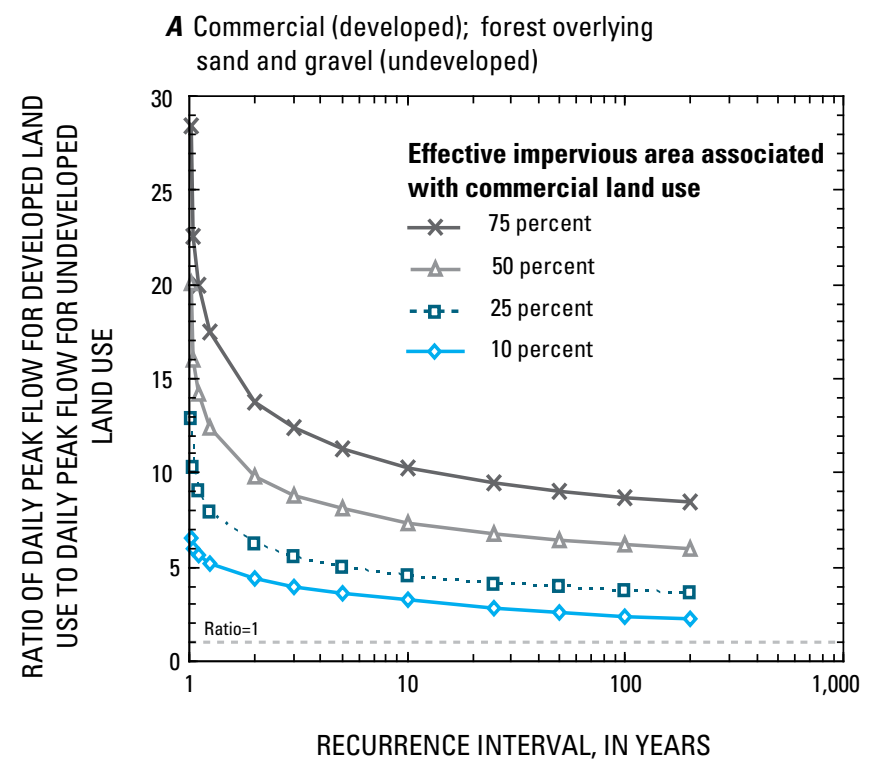

B Commercial (developed); forest overlying till (undeveloped)

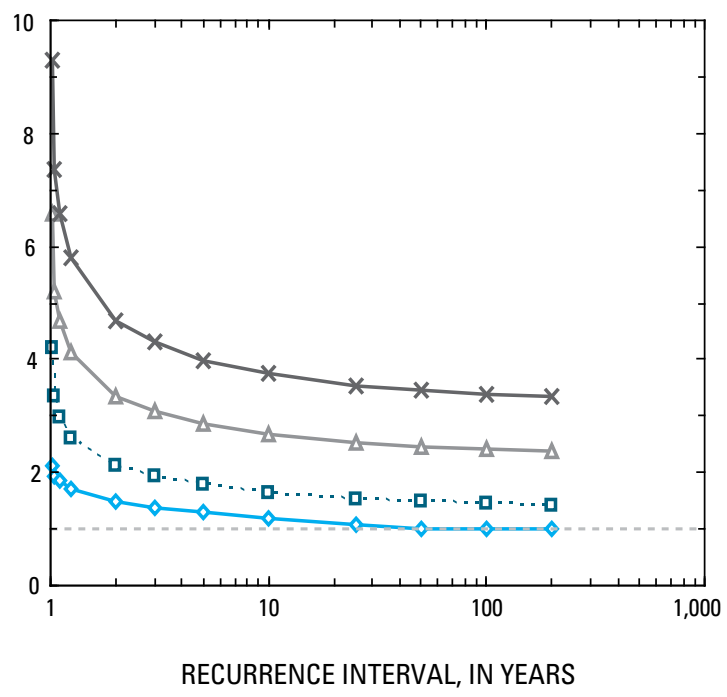

Figure 63. Ratios of the magnitudes of simulated daily peak flows for $(A)$ commercial (developed) and forest overlying sand and gravel (undeveloped) land use, and $(B)$ commercial (developed) and forest overlying till (undeveloped) land use as a function of recurrence interval and the amount of effective impervious area in the Ipswich River Basin, MA. 
development with 75 percent EIA (fig. 63A) than before the conversion. On the other extreme, simulated daily peak flows for 100-year floods were about the same after forest overlying till was converted to commercial development with 10 percent EIA (fig. 63B).

Simulated flood-peak-ratio curves are not applicable to all spatial scales. For example, it is unlikely that a large watershed would undergo such intensive urbanization as to achieve EIAs of 50 or 75 percent (the top two curves in figs. 63A, B). HSPF-model-calibrated EIAs for large drainage basins in eastern Massachusetts and Rhode Island are in the 5 to 8 percent range (Barbaro and Zarriello, 2006; Zarriello and Ries, 2000). Moreover, uniform land-use change to commercial development and uniform underlying geology are clearly not representative of larger basins. Therefore, the flood-peak ratios are most representative of the response in small, undeveloped catchments that may undergo uniform commercial development with varying amounts of EIA. In addition, these simulations assume the same infiltration capacity in pervious areas, regardless of the percentage of EIA associated with the development. Finally, the Ipswich River Basin HSPF model was less rigorously calibrated to high flows than to low flows, and model performance for large floods is relatively uncertain. For these reasons, the daily flood-peak ratios are best viewed as showing only relative effects of land-use change, as determined by the model parameter values assigned to individual HRUs, and are not representative of actual flood-peak changes in the basin.

\section{Cluster Development}

Simulations were conducted to evaluate the effects of cluster development on streamflow (fig. 64; table 17). For high-density residential development, clustering (60 acres undeveloped and 40 acres developed) generally reduced simulated high flows (defined here as flows equaled or exceeded less than 25 percent of the time) for HRUs overlying both sand and gravel and till compared to conventionally laid out development (figs. 64A, B). Clustering did not substantially change low flows (defined here as flows equaled or exceeded greater than 75 percent of the time) for HRUs overlying sand and gravel or till. Varying the EIA within the developed part of the parcel typically had less of an effect on simulated flows than clustering had. The exception was for the simulation with the highest EIA (56 percent EIA in the developed area), which produced high and low flows similar to the conventional development.

For low-density residential development, clustering (75 acres undeveloped and 25 acres developed) reduced high flows but also slightly reduced low flows compared to conventionally laid out development for both surficial geology types (figs. 64C, D). As discussed previously, simulated reductions in low flows were due to increased interception and evapotranspiration losses from the forested HRUs compared to the low-density residential HRUs. For low-density residential development, varying the EIA within the developed part of the parcel had a negligible effect on simulated streamflow. Simulated streamflow for a cluster development with a larger developed area (for example, 50 acres developed with 100 houses on 0.5 -acre lots and 50 acres undeveloped) would fall between the simulated flows for the conventional and clustered developments (simulations not shown).

Overall, clustering reduced simulated high flows and had variable effects on simulated low flows compared to conventional developments with the same number of houses. Lowdensity cluster developments, in particular, left a large part of the parcel forested, resulting in slightly lower low flows than conventional low-density developments with uniform lot sizes (figs. 64C, D). Simulated streamflow was relatively insensitive to the amount of EIA in the developed part of the parcel, particularly for cluster developments in which the developed area composed a relatively small fraction of the parcel. For example, for the low-density cluster development simulations conducted for this study, only 25 percent of the parcel was developed, and a reasonable EIA range of 7 to 28 percent in the developed area corresponded to an EIA range for the entire parcel of only 1.8 to 7 percent. In contrast, for the high-density cluster development simulations, more of the parcel was developed than for the low-density simulations; consequently, the EIA in the developed area of the high-density development had a larger effect on simulated streamflow than the low-density development had. Evaluation of other aspects of open-space preservation, such as possible beneficial effects on water quality, was beyond the scope of this study. 
$\boldsymbol{A}$

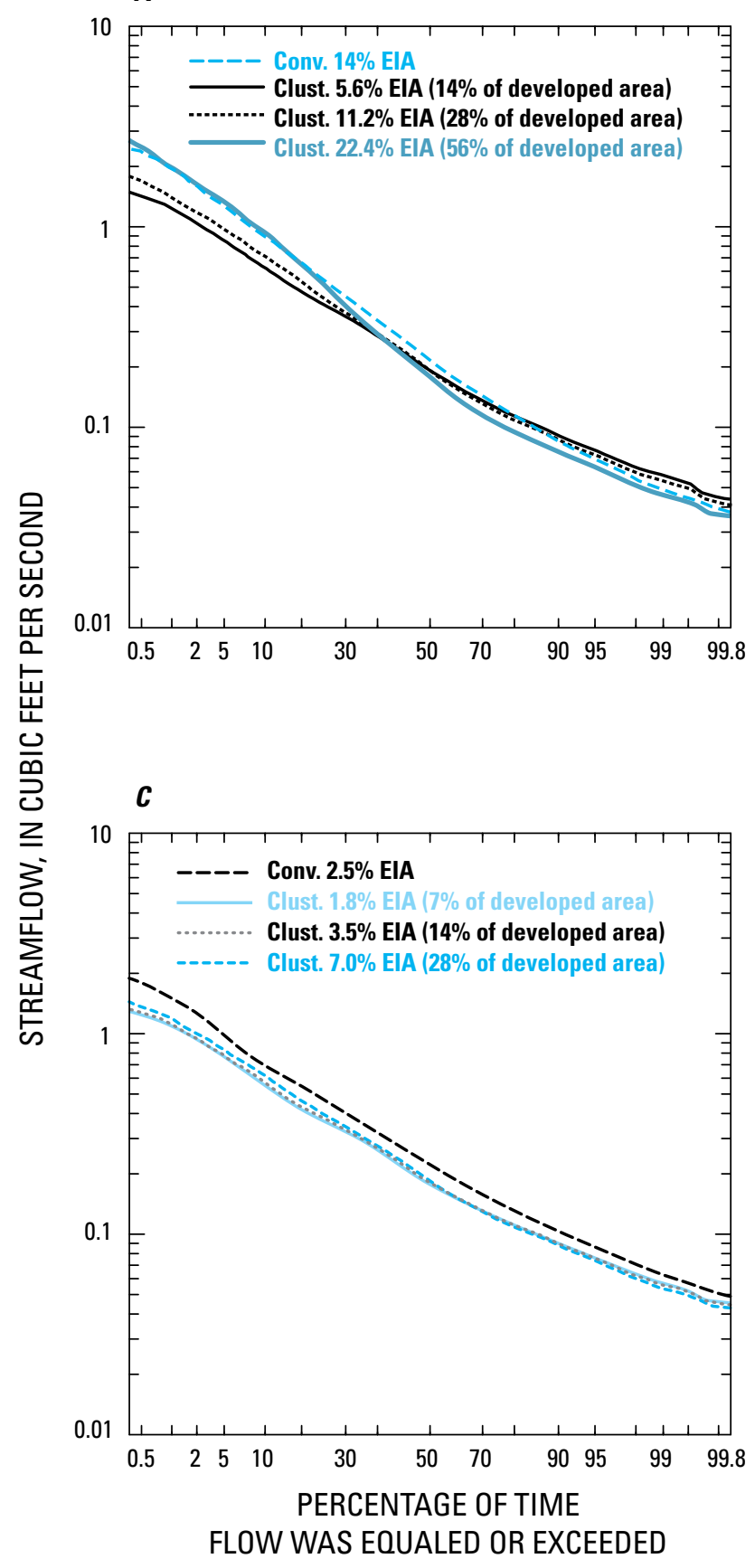

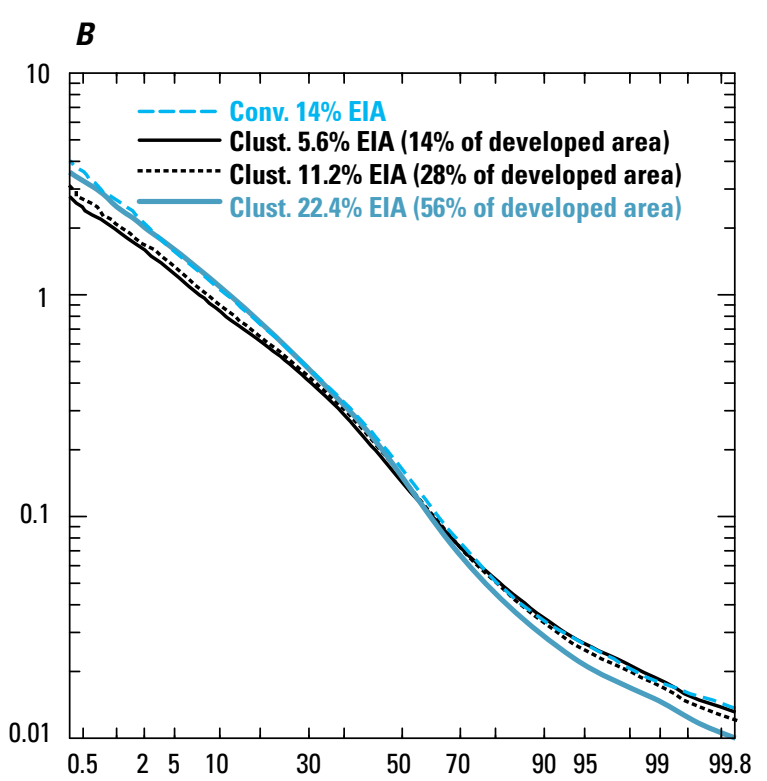

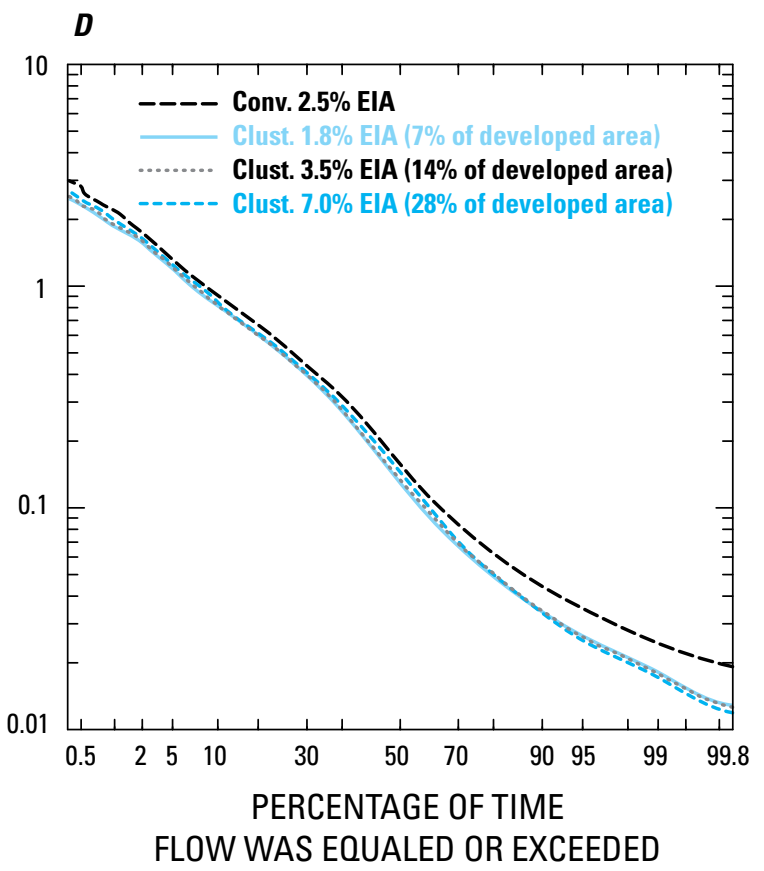

Figure 64. Flow-duration curves of daily-mean streamflow from long-term (1961-1995) simulations of runoff from 100-acre parcels of conventionally laid out (uniform) and cluster development with varying amounts of EIA in the developed part of the parcel for $(A)$ high-density residential overlying sand and gravel, $(B)$ high-density residential overlying till, $(C)$ low-density residential overlying sand and gravel, and (D) low-density residential overlying till, Ipswich River Basin, MA. The highdensity residential cluster development consists of 60 acres of undeveloped land and 40 acres of developed land, and the low-density residential cluster development consists of 75 acres of undeveloped land and 25 acres of developed land. Conv., conventionally laid out development; Clust., cluster development; EIA, effective impervious area. 


\section{Summary and Conclusions}

The USGS, in cooperation with the MDCR and the USEPA, used field and modeling studies to examine the effects of implementing selected LID techniques and waterdemand-reduction strategies on water quantity and quality in the Ipswich River Basin, which is stressed by residential and commercial water demands. The field studies and computer simulations demonstrate that implementation of LID practices can demonstrably affect stormwater runoff, even in small, highly pervious drainage areas. However, the effects may be difficult to discern when the changes in EIA and in the volume of runoff are small. The benefits of implementing these practices are likely greatest when they are either extensively incorporated into the original design for a development or when a substantially urbanized area is retrofitted with LID enhancements that redirect runoff away from storm sewers and into groundwater.

\section{Field-Study Findings}

Three field studies were designed to monitor the effects of LID practices on water quantity and quality. The first compared the changes in groundwater quality that occurred after a porous parking lot surface replaced a conventional, impervious one. The second examined the changes in stormwater flow and quality after a system of rain gardens, swales, and porous pavers was retrofitted in a 3-acre neighborhood to divert runoff from the streets into the groundwater rather than into storm sewers leading to Silver Lake. The third field study simultaneously monitored and sampled stormwater runoff from a conventional, rubber-membrane roof and from a vegetated green roof to compare their differences.

Results from the monitoring of water quality in the Silver Lake parking-lot wells indicate little change over the period of study. The changes that did occur are more likely associated with the physical process of parking-lot replacement, as reflected in the field characteristics, than with any effects of chemical contaminants entering the water table after infiltrating from the porous surfaces of the parking lot. Within the scope of this study, it seems reasonable to infer that installing the porous parking lot had no observable deleterious effects on groundwater quality.

The results of the Silver Lake Avenue runoff study indicated some modest gains in reducing runoff: the rainfallrunoff relation decreased somewhat, primarily for storms of less than $0.25 \mathrm{in}$. of rainfall, although not in a statistically significant amount. The decrease in EIA was not sufficient to bring about significant change in this small neighborhood with highly porous soils. Decreasing the amount of EIA in a study site with a greater proportion of impervious area than that in the Silver Lake Avenue/Dexter Street neighborhood might have had a more substantial effect that would have been reflected in changes to the rainfall-runoff ratio. Given the ambiguous results of the runoff volume aspects of the study, the inconsequential differences in water-quality constituent concentrations and loads were not surprising; in particular, storms sampled after the installation of the LID enhancements were characterized as having substantially more rainfall than those sampled prior to the enhancement installations. Small storms were sampled less frequently than large storms for water-quality analyses because small storms did not generate sufficient runoff for water-quality sampling. The design features were probably inadequate to reduce discharge sufficiently in order to achieve measurable results for large storms.

The roof runoff study clearly demonstrated the ability of the green roof to attenuate runoff, retaining at least 50 percent of the rainfall from most storms, and to store substantial amounts of precipitation. Both of these characteristics of green roofs depend on the amount of precipitation and antecedent dry periods associated with a given storm. The effects of the green roof on the water quality of runoff were less clear. Small storms tended to generate inadequate volumes of runoff for water-quality samples, and subsequently, there were no chemical analyses for small storms. Thus, the study did not account for the reduction in constituent load that occurred by virtue of the absence of runoff from small storms. The application of fertilizers, the composition of the growing medium, and the possible effects of metallic roof structures probably obscured the capacity of the medium to retain nutrients and metals from dryfall and rainfall.

\section{Simulation Findings}

The USGS, in consultation with the MDCR, USEPA, and a Technical Advisory Committee, created a set of hypothetical land-use change and water-management scenarios to investigate the effects on streamflow of implementing low-impactdevelopment practices in the Ipswich River Basin using the USGS Ipswich River Basin HSPF model. An updated baseline simulation was conducted to incorporate major changes in water-supply withdrawals from the upper basin that have taken place since the original baseline model was developed with 1989 to 1993 withdrawals. The incorporation of reduced groundwater withdrawals led to increases in simulated medium and low flows in the reaches above the South Middleton streamgage. Local effects on small streams in the immediate vicinity of wells with reduced withdrawals could be more pronounced, but these effects were not specifically evaluated with the model.

Information from a 2001 state-wide buildout analysis (Massachusetts Executive Office of Energy and Environmental Affairs, 2008) was used to simulate the effects of potential future development on streamflow in the Ipswich River Basin. Using 1991 land use as a baseline, the buildout analysis indicated that about 17 percent of the entire Ipswich River Basin was developable. Land-use change associated with buildout generally had modest effects (percent differences of less than 20 percent) on simulated streamflow in the Ipswich River Basin because most of the developable land in the basin in 
1991 was forested or open and zoned for low-density residential development, and model-calibrated EIA associated with low-density residential development was 2.5 percent. Consequently, increases in this type of land use did not result in large changes in the amount of EIA in a drainage area. In areas with relatively substantial amounts of land zoned for commercial use (for example, in reach 27 where EIA in the subbasin increased from 8.6 percent in 1991 to 28.9 percent at buildout), effects on simulated flows were more pronounced.

EIA upstream from the South Middleton streamgage was reduced by 50 percent as a surrogate for LID retrofits that decrease EIA. Widespread reduction of EIA to 50 percent of values in the updated baseline model (1991 land use) had modest effects (percent differences of less than 20 percent) on simulated streamflow above the South Middleton station. Even in this relatively urban part of the Ipswich River Basin, the heterogeneous mix of land uses results in EIAs that are small percentages (1 to 22 percent) of subbasin areas.

Data from water-conservation pilot projects were scaled up to the town level and used to simulate the effects of widespread application of these programs on streamflow. For communities with water withdrawals from the basin, hypothetical water-use reductions from broad application of the pilot project data ranged from 1.4 percent (Salem-Beverly water supply) to 8.5 percent (Hamilton) of average 1989-1993 withdrawals. Withdrawal reductions in this range (less than 10 percent) had very minor effects on simulated low flows in most of the rivers and streams in the basin affected by groundwater withdrawals. Impacts of reduced water withdrawals may have more significant impacts at a local scale in the vicinity of the withdrawal locations, but a local-scale analysis of the impact of reduced water withdrawals was beyond the scope of this study.

Hypothetical local-scale simulations conducted to evaluate the hydrologic effects of land-use change, surficial geology, and development patterns on a local scale (100 acres) provide valuable understanding of the conditions for which LID practices have the greatest potential benefits. Specifically, simulations were conducted to evaluate the effect on streamflow of (1) uniform land-use change for conventionally laid out development (that is, uniform lot sizes in the development); (2) the amount of EIA, with EIA less than model-calibrated values representing an application of LID, and EIA greater than model-calibrated values representing an upper limit for a given land-use category; (3) surficial geology; and (4) cluster developments. Converting undeveloped, forested land to developed land increased simulated median 1-day high flows (median of 1-day annual high flows for 1961-1995 simulation) by up to 1,250 percent, depending on the underlying surficial geology and the type of development. Conversion of forest overlying sand and gravel to commercial development produced the maximum increase in the simulated median 1-day high flow, from 0.49 to $6.60 \mathrm{ft}^{3} / \mathrm{s}$. Converting forest to low-density or high-density residential development also increased simulated high flows, but these changes also increased most simulated medium and low flows for
HRUs underlain by till, and sand and gravel. Flows increased because both residential HRUs were simulated to have less evapotranspiration losses than forested HRUs, producing more discharge to streams as interflow or base flow.

Simulations of runoff from 100-acre parcels with uniform land use were conducted to evaluate the sensitivity of streamflow to EIA. Results indicate that the largest reduction in streamflow alteration could potentially be achieved by implementing LID in areas with commercial land use and highdensity residential land use because more EIA was available for reduction in commercial areas and high-density residential areas than in other land-use areas. Only modest changes in simulated streamflow were observed for low-density residential land use.

To evaluate the magnitude of flood-peak differences produced by development, 1-day high flow (daily peak flow) frequency probabilities were computed for selected 100-acre developed and undeveloped HRUs. Ratios of simulated flood peaks after development (the commercial HRU) to those before development (the forest overlying till HRU or the forest overlying sand and gravel HRU) indicated that simulated daily peak flows declined with increasing recurrence interval and the amount of EIA associated with commercial development. Simulated flood peaks after development were as much as 30 times higher than before development for small floods with a recurrence interval on the order of 1 year or less. Simulated daily peak flows for larger floods, for example 100-year floods, were 10 times higher after forest overlying sand and gravel was converted to commercial development with 75 percent EIA. On the other extreme, simulated daily peak flows for 100 -year floods were about the same after forest overlying till was converted to commercial development with 10 percent EIA. The flood-peak ratios are most representative of the response in small, undeveloped subbasins that may undergo uniform commercial development with varying amounts of EIA.

Results of simulations conducted to evaluate cluster development indicate that clustering practices reduce high flows and have variable effects on low flows when compared to conventional development with the same number of houses. For low-density cluster developments, leaving a large part of the area forested resulted in slightly lower low flows than for a conventional low-density development with uniform lot sizes. Flows from a cluster development more closely approximated pre-development flows than did flows from conventional lowdensity development. Simulated streamflow was found to be relatively insensitive to the amount of EIA in the developed part of the parcel, particularly for cluster developments in which the developed area was relatively small.

Because of data limitations and computational efficiency, numerical watershed models such as HSPF simplify the complex processes and physical characteristics of a drainage basin. Of particular relevance for the present study, model calibration reflected the combined effects of the HRUs (both PERLNDs and IMPLNDs) and reach characteristics. Hydrologic judgment was used to determine the response of different 
PERLNDs and IMPLNDs, but information was not available to calibrate the individual HRUs. In addition, the amount of EIA associated with each developed land-use category was determined through model calibration and represents average subbasin-scale EIA. Consequently, the magnitudes of changes produced by altering the distribution of HRUs are uncertain and simulated changes are best viewed as relative rather than absolute.

\section{References Cited}

Alley, W.M., and Veenhuis, J.E., 1983, Effective impervious area in urban runoff modeling: Journal of Hydraulic Engineering, v. 109, no. 2, p. 313-319.

Armstrong, D.S., Richards, T.A., and Parker, G.W., 2001, Assessment of habitat, fish communities, and streamflow requirements for habitat protection, Ipswich River, Massachusetts, 1998-99: U.S. Geological Survey WaterResources Investigations Report 01-4161, 72 p.

Barbaro, J.R., 2007, Simulation of the effects of water withdrawals, wastewater-return flows, and land-use change on streamflow in the Blackstone River Basin, Massachusetts and Rhode Island: U.S. Geological Survey Scientific Investigations Report 2007-5183, 93 p.

Barbaro, J.R., and Zarriello, P.Z., 2006, A precipitation-runoff model for the Blackstone River Basin, Massachusetts and Rhode Island: U.S. Geological Survey Scientific Investigations Report 2006-5213, 95 p.

Barlow, P.M., 2000, Documentation of computer program STRMDEPL-A program to calculate streamflow depletion by wells using analytical solutions, in Zarriello, P.J. and Ries, K.G. III, 2000, A precipitation runoff model for the analysis of the effects of water withdrawals on streamflow, Ipswich River Basin, Massachusetts: U.S. Geological Survey Water-Resources Investigations Report 00-4029, 99 p.

Beighley, R.E., and Moglen, G.E., 2003, Adjusting measured peak discharges from an urbanizing watershed to reflect a stationary land use signal: Water Resources Research, v. 36, no. 4, 1093 p., doi:10.1029/2002/WR001846.

Bent, G.C., 2001, Effects of forest-management activities on runoff components and groundwater recharge to Quabbin Reservoir, central Massachusetts: Forest Ecology and Management, v. 143, p. 115-129.

Bent, G.C., and Steeves, P.A., 2006, A revised logistic regression equation and an automated procedure for mapping the probability of a stream flowing perennially in Massachusetts: U.S. Geological Survey Scientific Investigations Report 2006-5031, 107 p.
Berghage, Robert, Jarrett, Al, Beattie, David, Kelley, Kathleen, Husain, Shazia, Rezai, Farzaneh, Long, Bret, Negassi, Ayako, Cameron, Robert, and Hunt, William, 2007, Quantifying evaporation and transpirational water losses from green roofs and green roof media capacity for neutralizing acid rain: Center for Green Roof Research, Pennsylvania State University, College Park, PA, variously paged.

Bicknell, B.R., Imhoff, J.C., Kittle, J.L., Jr., Jobes, T.H., and Donigian, A.S., Jr., 2000, Hydrological Simulation Program-FORTRAN User's manual for release 12: Mountain View, CA, AQUA TERRA Consultants, variously paged.

Booth, D.B., and Jackson, C.R., 1997, Urbanization of aquatic systems, degradation thresholds, stormwater detection, and the limits of mitigation: Journal of the American Water Resources Association, v. 33, no. 5, p. 1077-1089.

Bosch, J.M., and Hewlett, J.D., 1982, A review of catchment experiments to determine the effects of vegetation changes on water yield and evapotranspiration: Journal of Hydrology, v. 55, p. 3-23.

Brandes, D., Cavallo, G.J., and Nilson, M.L., 2005, Base flow trends in urbanizing watersheds of the Delaware River Basin: Journal of the American Water Resources Association, v. 41, no. 6, p. 1377-1391.

Calder, I.R., 1993, Hydrologic effects of land-use change, in Maidment, D.R., ed., Handbook of Hydrology: New York, McGraw-Hill, Inc., p. 13.1-13.50.

Claessens, L., Hopkinson, C., Rastetter, E., and Vallino, J., 2006, Effect of historical changes in land use and climate on the water budget of an urbanizing watershed: Water Resources Research, v. 42, WO3426, doi:10.1029/2005WR004131.

Coles, J.F., Cuffney, T.F., McMahon, G., and Beaulieu, K.M., 2004, The effects of urbanization on the biological, physical, and chemical characteristics of coastal New England streams: U.S. Geological Survey Professional Paper 1695, $47 \mathrm{p}$.

Crump, B.C., and Hobbie, J.E., 2005, Synchrony and seasonality in bacterioplankton communities of two temperate rivers: Limnology and Oceanography, v. 50, p. 1718-29.

Dietz, M.E., 2007, Low impact development practices-A review of current research and recommendations for future directions: Water, Air, and Soil Pollution, p. 351-63.

Dietz, M.E., and Clausen, J.C., 2008, Stormwater runoff and export changes with development in a traditional and low impact subdivision: Journal of Environmental Management, v. 87 , p. $560-6$. 
Dow, C.L., and DeWalle, D.R., 2000, Trends in evaporation and Bowen ratio on urbanizing watersheds in eastern United States: Water Resources Research, v. 36, no.7, p. $1835-1843$.

Edwards, T.K., and Glysson, G.D., 1999, Field methods for measurement of fluvial sediment: U.S. Geological Survey Techniques of Water-Resources Investigations, book 3, chap. C2, 89 p. (Available at http://water.usgs.gov/pubs/ twri/twri3-c2/pdf/TWRI_3-C2.pdf.)

Emilsson, Tobias, Berndtsson, J.C., Mattsson, J.E., and Rolf, Kaj, 2007, Effect of using conventional and controlled release fertilizers on nutrient runoff from various vegetated roof systems: Ecological Engineering, v. 29, p. 260-71.

Filoso, Solange, Vallino, Joseph, Hopkinson, Charles, Rastetter, Edward, and Claessens, Luc, 2004 Modeling nitrogen transport in the Ipswich River Basin, Massachusetts, using a Hydrological Simulation Program in FORTRAN (HSPF): Journal of the American Water Resources Association, v. 40, no. 5, p. 1365-84.

Grady, S.J., 1994, Effects of land use on quality of water in stratified-drift aquifers in Connecticut: U.S. Geological Survey Water-Supply Paper 2381-B, 56 p.

Grimm, N.B., Faeth, S.H., Golubiewski, N.E., Redman, C.L., Wu, J., Bai, X., and Briggs, J.M., 2008, Global change and the ecology of cities: Science, v. 319, p. 756-60.

Helsel, D.R., 2005a, Nondetects and data analysis: Statistics for censored environmental data: Hoboken, NJ, John Wiley \& Sons, Inc., $250 \mathrm{p}$.

Helsel, D.R., 2005b, Insider censoring: Distortion of data with nondetects: Human and Ecological Risk Assessment, v. 11, p. $1127-37$.

Hollis, G.E., 1975, The effect of urbanization on floods of different recurrence interval: Water Resources Research, v. 11, no. 3 , p. 431-435.

Hood, M., Clausen, J.C., and Warner, G.S., 2007, Comparison of stormwater lag times for low impact and traditional residential development: Journal of the American Water Resources Association, v. 43, no. 4, p. 1036-46.

Hornbeck, J.W., Adams, M.B., Corbett, E.S., Verry, E.S., and Lynch, J.A., 1993, Long-term impacts of forest treatments on water yield: a summary for northeastern USA: Journal of Hydrology, v. 150, p. 323-344.

Jennings, M., and Doyle, W.H., Jr., 1978, Deterministic modeling of urban storm water processes, Broward County, Florida, in Proceedings International Symposium on Urban Storm Water Management: Lexington, University of Kentucky, July 1978, p. 275-281.
Leopold, L.B., 1968, Hydrology for urban land planningA guidebook on the hydrologic effects of urban land use: U.S. Geological Survey Circular 554, 18 p.

Lerner, D.N., 2002, Identifying and quantifying urban recharge: A review: Hydrogeology Journal, v. 10, p. 143-152.

Massachusetts Executive Office of Environmental Affairs, 2008, Buildout maps and analyses, accessed April 7, 2008, at http://commpres.env.state.ma.us/content/buildout.asp.

Moscrip, A.L, and Montgomery, D.R, 1997, Urbanization, flood frequencies, and salmon abundance in Puget lowland streams: Journal of the American Water Resources Association, v. 33, no. 6, p. 1289-1297.

Oberndorfer, E., Lundholn, J., Bass, B., Coffman, R.R., Doshi, H., Dunnett, N., Gaffin, S., Köhler, M., Liu, K.K.Y., and Rowe, B., 2007, Green roofs as urban ecosystems: Ecological structures, functions, and services: Bioscience, v. 57, no. 10 , p. 823-33.

Robinson, M., Gannon, B., and Schuch, M., 1991, A comparison of the hydrology of moorland under natural conditions, agricultural use, and forestry: Hydrological Sciences, v. 36, p. 565-577.

Rose, S., and Peters, N.E., 2001, Effects of urbanization on streamflow in the Atlanta area (Georgia, USA): A comparative hydrological approach: Hydrological Processes, v. 15, p. 1441-1457.

Roy, A.H., and Shuster, W.D., 2009, Assessing impervious surface connectivity and applications for watershed management: Journal of the American Water Resources Association, v. 45 , no. 1 , p. $198-209$.

Roy, S.P., and Braga, A.M., 2009, Saving Silver Lake: Civil Engineering, v. 79, no. 2, p. 72-79.

Sammel, E.A., Brackley, R.A., and Palmquist, W.N., Jr., 1964, Synopsis of water resources of the Ipswich River Basin, Massachusetts: U.S. Geological Survey Hydrological Investigations Atlas HA-196.

Selbig, W.R., and Bannerman, R.T., 2008, A comparison of runoff quantity and quality from two small basins undergoing implementation of conventional- and low-impactdevelopment (LID) strategies: Cross Plains, Wisconsin, water years 1999-2005: U.S. Geological Survey Scientific Investigations Report 2008-5008, $57 \mathrm{p}$.

U.S. Geological Survey, variously dated, National field manual for the collection of water-quality data: U.S. Geological Survey Techniques of Water-Resources Investigations, book 9, chaps. A1-A9 (Available at http://pubs.water.usgs.gov/twri9A.). 
Williams, Michael, Hopkinson, Charles, Rastetter, Edward, Vallino, Joseph, and Claessens, Luc, 2005, Relationships of land use and stream solute concentrations in the Ipswich River Basin, Northeastern Massachusetts: Water, Air \& Soil Pollution, v. 161, p. 55-74.

Zarriello, P.J., 2004, Simulated effects of the 2003 permitted withdrawals and water-management alternatives on reservoir storage and firm yields of three surface-water supplies, Ipswich River Basin, Massachusetts: U.S. Geological Survey Scientific Investigations Report 2004-5122, 53 p.

Zarriello, P.J., 2002a, Simulation of reservoir storage and firm yields of three surface-water supplies, Ipswich River Basin, Massachusetts: U.S. Geological Survey Water-Resources Investigations Report 02-4278, $50 \mathrm{p}$.
Zarriello, P.J., 2002b, Effects of water-management alternatives on streamflow in the Ipswich River Basin, Massachusetts: U.S. Geological Survey Open-File Report 01-483, $30 \mathrm{p}$.

Zarriello, P.J., and Barlow, L.K., 2002, Measured and simulated runoff to the Lower Charles River, Massachusetts, October 1999-September 2000: U.S. Geological Survey Water-Resources Investigations Report 02-4129, 89 p.

Zarriello, P.J., and Ries, K.G., III, 2000, A precipitation-runoff model for analysis of the effects of water withdrawals on streamflow, Ipswich River Basin, Massachusetts: U.S. Geological Survey Water-Resources Investigations Report 00-4029, 99 p. (Available at http://pubs.usgs.gov/wri/ wri004029/) 


\section{Appendix 1}


Table 1-1. Town data used to scale up results of water-conservation pilot projects conducted in the Ipswich River Basin, MA, for calculating hypothetical water savings for towns with municipal water supplies in the Basin.

[Information compiled by the Massachusetts Department of Conservation and Recreation.]

\begin{tabular}{|c|c|c|c|c|c|}
\hline Town & $\begin{array}{c}\text { Number of } \\
\text { single family } \\
\text { detached homes }\end{array}$ & $\begin{array}{c}\text { Total } \\
\text { number of } \\
\text { households }\end{array}$ & $\begin{array}{l}\text { Percent of water } \\
\text { supply from } \\
\text { sources in the } \\
\text { Ipswich River } \\
\text { Basin }\end{array}$ & $\begin{array}{l}\text { Total area of athletic } \\
\text { fields irrigated with } \\
\text { public water supplies } \\
\text { (acres) }\end{array}$ & $\begin{array}{l}\text { Total area of athletic } \\
\text { fields irrigated with } \\
\text { onsite wells located in } \\
\text { the Ipswich River Basin } \\
\text { (acres) }\end{array}$ \\
\hline Wilmington & 6,368 & 7,158 & 42 (Summer only) & 3.2 & 35 \\
\hline \multicolumn{6}{|c|}{ Danvers Water Supply } \\
\hline Danvers & 6,299 & 9,762 & 100 & 15 & 0 \\
\hline North Reading & 4,029 & 4,870 & 40 (Summer only) & 0 & 14 \\
\hline Peabody & 10,959 & 18,898 & 50 & 34 & 13 \\
\hline Hamilton & 2,358 & 28,525 & 100 & 1.5 & 12 \\
\hline Ipswich & 3,723 & 5,601 & 25 & 11 & 0 \\
\hline Salem & 4,915 & 18,175 & 100 & 19 & 0 \\
\hline Beverly & 8,450 & 16,275 & 100 & 23 & 0 \\
\hline Lynnfield & 3,705 & 4,273 & 54 & 0 & 1 \\
\hline Lynn & 11,673 & 34,690 & 20 & 22 & 0 \\
\hline
\end{tabular}

${ }^{1} 50-60$ percent of Middleton residents and 15 percent of Topsfield residents use private wells, but all are located within the Ipswich River Basin. For Hydrological Simulation Program-FORTRAN simulations, the hypothetical savings at these private wells were attributed to the respective public water supply sources for each town. 
Table 1-2. Calculations and assumptions used to scale up data to the town level from the water-conservation pilot study conducted in the Ipswich River Basin, MA.

[Information compiled by the Massachusetts Department of Conservation and Recreation. Reductions were scaled up to the town level for towns with municipal water supplies in the Ipswich River Basin, so that the effects of reductions on streamflow could be simulated with the Hydrological Simulation ProgramFORTRAN (HSPF) model previously developed for the Basin. ${ }^{1}$ ]

\begin{tabular}{|c|c|c|}
\hline $\begin{array}{l}\text { Water-conservation } \\
\text { pilot project }\end{array}$ & $\begin{array}{l}\text { Description of per unit savings and assumptions } \\
\text { used to scale results up to town level }\end{array}$ & $\begin{array}{l}\text { Per unit savings based } \\
\text { on water-conservation } \\
\text { pilot projects } \\
\text { (gallons/month) }\end{array}$ \\
\hline \multirow{3}{*}{$\begin{array}{l}\text { 800-gallon rainwater } \\
\text { harvesting systems }\end{array}$} & Average savings per participating single family household: & 433 \\
\hline & Assumption that $1 / 3$ of the single-family homes in all Ipswich towns participate. & \\
\hline & $\begin{array}{l}\text { Reduction in withdrawals at Ipswich water-supply sources }=433 \text { gallons } / \text { month } \\
* 1 / 3 * \text { number of single family homes } * \text { percent of water supply pumped from } \\
\text { Ipswich sources. }\end{array}$ & \\
\hline \multirow{4}{*}{$\begin{array}{l}\text { Low-flow indoor fixtures } \\
\text { and appliances }\end{array}$} & Average savings per participating household: & 450 \\
\hline & $\begin{array}{l}\text { Assumption that participation rates in other Ipswich towns would resemble those } \\
\text { observed in town with the pilot program (approximately } 9 \text { percent). }\end{array}$ & \\
\hline & Average savings per household town-wide: & 35 \\
\hline & $\begin{array}{l}\text { Reduction in withdrawals at Ipswich water-supply sources }=35 \text { gallons } / \text { month * } \\
\text { number of households * percent of water supply from Ipswich sources. }\end{array}$ & \\
\hline \multirow{4}{*}{$\begin{array}{l}\text { Soil amendments at athletic } \\
\text { fields }\end{array}$} & Average per-acre savings resulting from zeolite soil amendment: & 6,671 \\
\hline & Assumption that all athletic fields are treated similarly to pilot-study field. & \\
\hline & $\begin{array}{l}\text { Reduction in withdrawals for all athletic fields currently irrigated by public water } \\
=6,671 \text { gallons/month * acreage } * \text { percent of water supply from Ipswich } \\
\text { sources. }\end{array}$ & \\
\hline & $\begin{array}{l}\text { Reduction in withdrawals for all athletic fields irrigated by on-site wells within } \\
\text { the Ipswich River Basin }=6,671 \text { gallons/month * acreage. }\end{array}$ & \\
\hline \multirow{4}{*}{$\begin{array}{l}\text { Weather-sensitive irrigation } \\
\text { systems on athletic fields }\end{array}$} & Average per-acre savings resulting from weather-based irrigation systems: & $16,241^{2}$ \\
\hline & $\begin{array}{l}\text { Assumption that all athletic fields irrigated were equipped with weather-sensitive } \\
\text { irrigation systems. }\end{array}$ & \\
\hline & $\begin{array}{l}\text { Reduction in withdrawals for all athletic fields currently irrigated by public water } \\
=16,241 \text { gallons/month * acreage * percent of water supply from Ipswich } \\
\text { sources. }\end{array}$ & \\
\hline & $\begin{array}{l}\text { Reduction in withdrawals for all athletic fields irrigated by onsite wells within the } \\
\text { Ipswich River Basin }=16,241 \text { gallons/month } * \text { acreage. }\end{array}$ & \\
\hline
\end{tabular}

\footnotetext{
${ }^{1}$ For HSPF simulations, reductions in non-public groundwater supply sources were attributed to the public-water supply sources in the same town.

${ }^{2}$ Subsequent to the HSPF simulation, DCR provided a revised per-acre water savings for the weather-sensitive irrigation systems of 21,128 gal/month. See text for discussion of the effects of this revision.
} 
114 Effects of Selected Low-Impact-Development Techniques on Water Quality and Quantity in the Ipswich River Basin

THIS PAGE INTENTIONALLY LEFT BLANK 
Prepared by the Pembroke Publishing Service Center.

For more information concerning this report, contact:

Director

U.S. Geological Survey

Massachusetts-Rhode Island Water Science Center 10 Bearfoot Road

Northborough, MA 01532

dc_ma@usgs.gov

or visit our Web site at:

http://ma.water.usgs.gov 

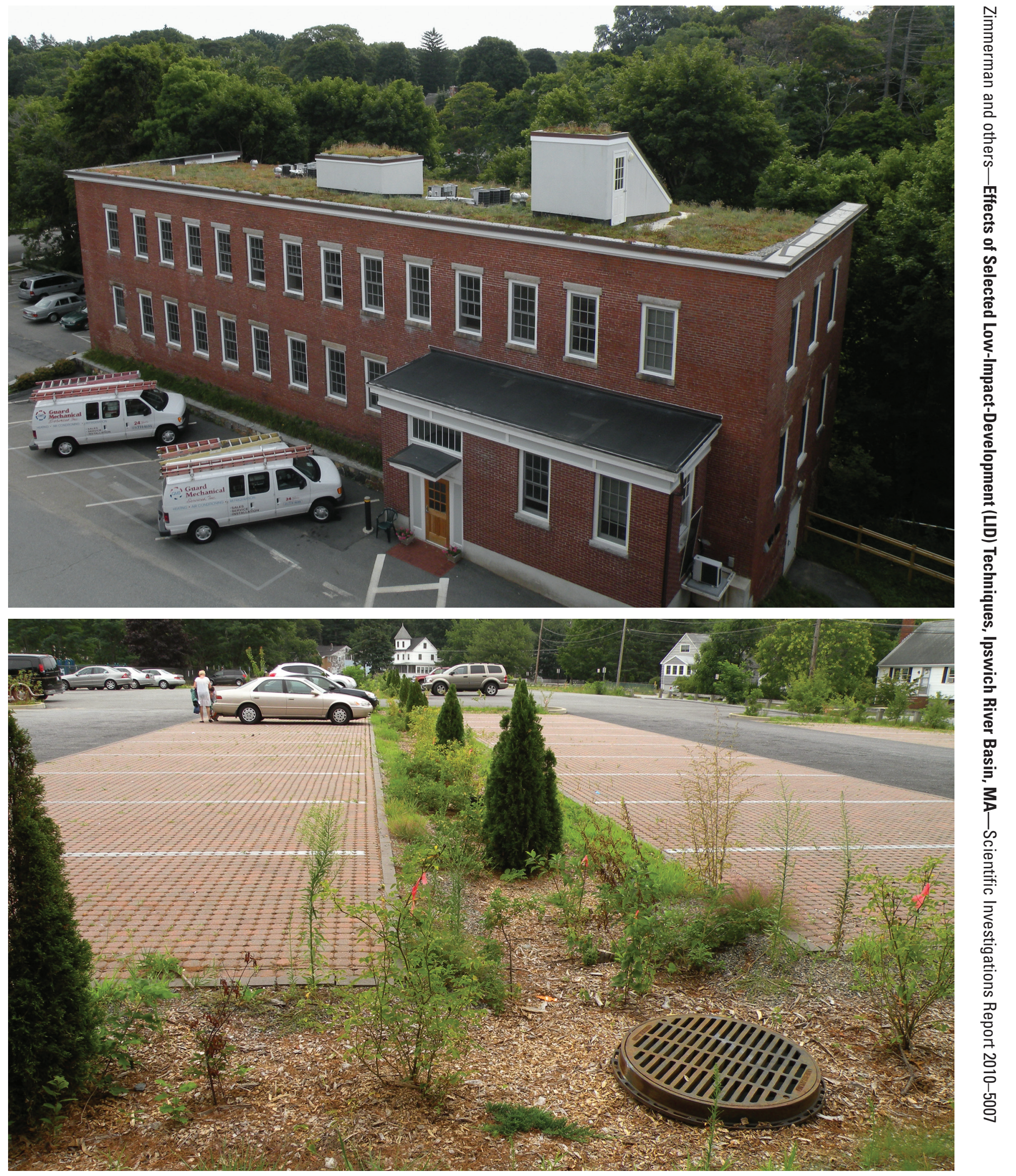